
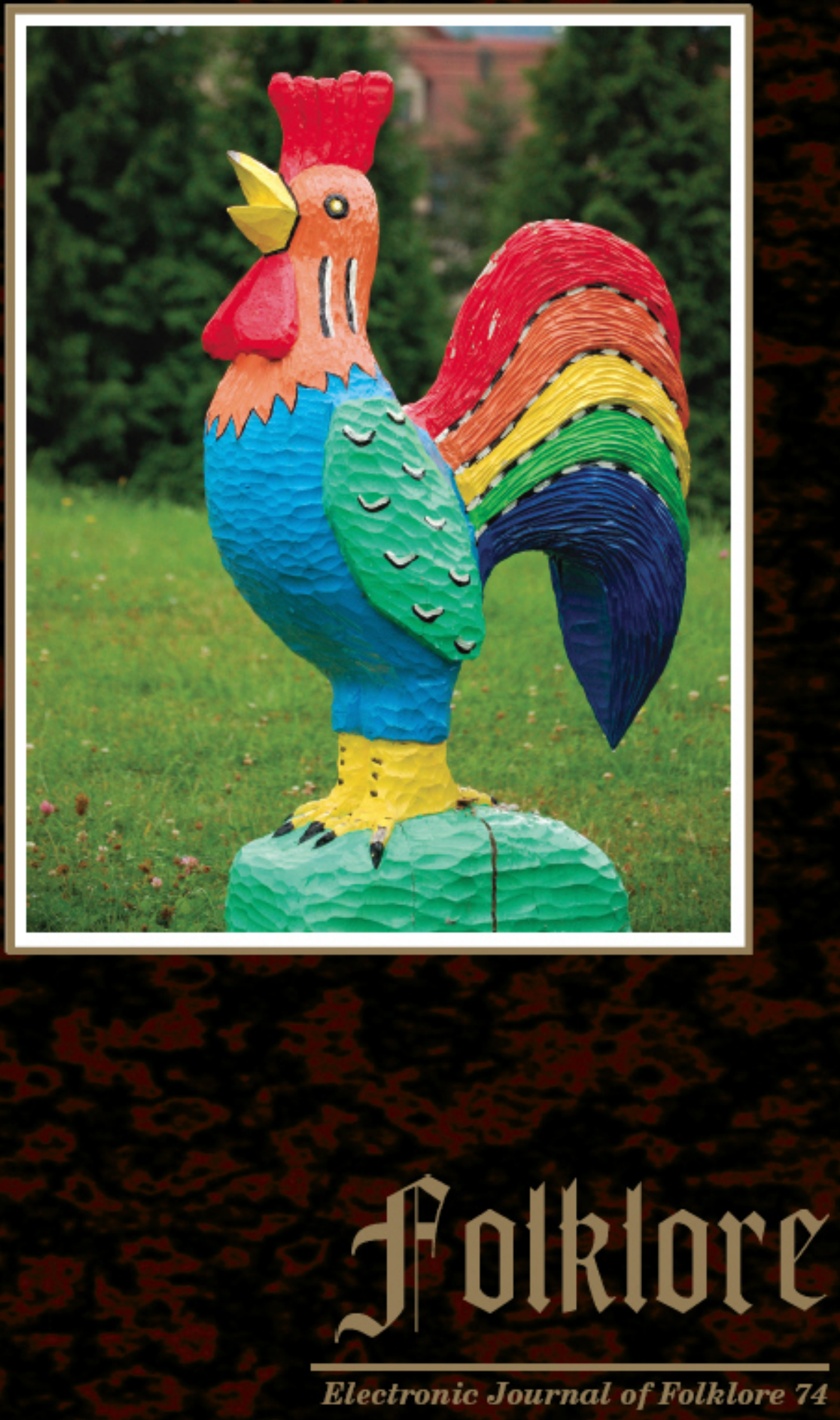


\section{EDITORIAL NOTE}

Folklore: Electronic Journal of Folklore (ISSN 1406-0957, e-version ISSN 1406-0949) is a peer-reviewed journal published three times a year by the Department of Folkloristics at the Estonian Literary Museum. Full texts of articles are published both in a printed version and electronically. Online access to the electronic version of the journal is free. Subscription to single issues as well as annual subscription is available. Folklore: Electronic Journal of Folklore is indexed in EBSCO Publishing Humanities International Complete, Thomson Reuters Arts \& Humanities Citation Index, MLA International Bibliography, Ulrich's Periodicals Directory, Inter-nationale Volkskundliche Bibliographie / International Folklore Bibliography / Bibliographie Internationale d'Ethnologie, Open Folklore, C.E.E.O.L., Scopus.

Folklore: Electronic Journal of Folklore welcomes unpublished articles by scholars of any country on any aspect of cultural studies in the broadest sense, all genres of folklore and comparative religion and related fields, including articles on mythology, religion, and tradition, paremiology, narratives, poetic folklore, ethnomusicology, archaeology, etc, Submissions simultaneously submitted for publication elsewhere will not be considered. All papers are anonymously refereed by two independent scholars. The editors will notify the authors about acceptance, expected alterations or rejection of the article. (Please also consult the instructions inside the back cover.)

We will be happy to answer any questions you might have and look forward to receiving your contribution.

Sincerely yours,

Mare Kõiva (mare@folklore.ee)

Andres Kuperjanov (cps@folklore.ee) 


\section{Folklore}

Electronic Journal of Folklore http://www.folklore.ee/folklore Vol. 74

2018 
Folk Belief and Media Group

of the Estonian Literary Museum

Estonian Institute of Folklore

\section{Folklore}

Electronic Journal of Folklore

Vol. 74

Edited by Mare Kõiva \& Andres Kuperjanov

ELM Scholarly Press

Tartu 2018 
Editor in chief

Co-editor

Copy editor

News and reviews

Design

Layout
Mare Kõiva

Andres Kuperjanov

Tiina Mällo

Piret Voolaid

Andres Kuperjanov

Diana Kahre

Editorial board 2015-2020: Dan Ben-Amos (University of Pennsylvania, USA), Larisa Fialkova (University of Haifa, Israel), Diane Goldstein (Indiana University, USA), Terry Gunnell (University of Iceland), Jawaharlal Handoo (University of Mysore, India), Frank Korom (Boston University, USA), Jurij Fikfak (Institute of Slovenian Ethnology), Ülo Valk (University of Tartu, Estonia), Wolfgang Mieder (University of Vermont, USA), Irina Sedakova (Russian Academy of Sciences).

The journal is supported by the Estonian Ministry of Education and Research (IUT 22-5), the European Union through the European Regional Development Fund (Centre of Excellence in Estonian Studies), the state programme project EKKM14-344, and the Estonian Literary Museum.

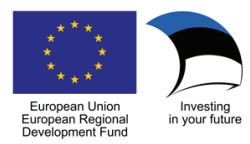

Indexed in EBSCO Publishing Humanities International Complete, Thomson Reuters Arts \& Humanities Citation Index, MLA International Bibliography, Ulrich's Periodicals Directory, Internationale Volkskundliche Bibliographie / International Folklore Bibliography / Bibliographie Internationale d'Ethnologie, Open Folklore, C.E.E.O.L., Scopus

\section{Editorial address:}

Folklore: Electronic Journal of Folklore

Vanemuise 42-235

51003 Tartu

Estonia

phone: $\quad+3727377740$

fax: $\quad+3727377706$

e-mail: folklore@folklore.ee

home page: http://www.folklore.ee/folklore

All rights reserved

(C) Estonian Literary Museum

Estonian Institute of Folklore

Authors

Design Andres Kuperjanov

According to Creative Commons licence BY-NC-ND 4.0

ISSN 1406-0957

doi:10.7592/FEJF2018.74 


\section{CONTENTS}

Creativity and Humor in the Online Folklore of the 2014 Elections in Hungary

Katalin Vargha

Gay Clowns, Pigs and Traitors: An Emotion Analysis of Online Hate Speech Directed at the Swedish-Speaking Population in Finland

Karin Sandell

Constructing Alien Space in South Slavic Oral Lyric

Ana Vukmanović

Folk Mystic: A Narrative of a Polish Highlander Cunegonde Siwiec

Tomasz Kalniuk

Dynamic Musicscapes in Northern Greece: A Roma Case Study

Christos Papakostas, Dimitris Goulimaris, Maria Douma

On a Possible Characteristic of the Governing System of Pharaoh

Amenhotep IV (Akhenaten)

Tarmo Kulmar

Heritage on Demand: UNESCO Intangible Cultural Heritage

Initiative in Croatian Context

Marijana Hameršak, Iva Pleše

In Memoriam

Barre Toelken

News IN BRIEF

Comparative Mythology on the Earth and Humankind: Past, Present and Future.

Irina Sedakova, Marina Valentsova

Book REviEw

Literature in an Esoteric Key. Annemarie Sorescu-Marinković 


\title{
CREATIVITY AND HUMOR IN THE ONLINE FOLKLORE OF THE 2014 ELECTIONS IN HUNGARY
}

\author{
Katalin Vargha \\ Research Center for the Humanities \\ Hungarian Academy of Sciences, Hungary \\ e-mail:vargha.katalin@btk.mta.hu
}

\begin{abstract}
In the twenty-first century, digital media (including email, blogs, and social networks) plays an important role in political communication - both in the official communication of political campaigns and in the popular political humor of the elections. This paper focuses on the online, mainly humorous, folklore of the 2014 Hungarian elections. It demonstrates how, using traditional patterns of folklore as well as individual creativity, this material reflects the actual political situation.
\end{abstract}

Keywords: election campaigns, folklore, internet, memes, political humor

\section{INTRODUCTION}

Hungary held two elections in the spring of 2014: the parliamentary election on April 6, and the election of the Hungarian delegation to the European Parliament on May 25. This paper will examine the mostly humorous online election folklore, which proved highly variable and popular among internet users during the campaign period preceding these two elections. This topic was chosen as a case study on online folklore or internet folklore for multiple reasons:

(1) Political elections, especially their preceding campaigns, inspire vernacular reactions that include vast amounts of folkloric texts, most of which fit into specific genres such as election rhymes, recruitment songs, anecdotes, jokes, etc.

(2) The technological advances of the twenty-first century allow election folklore to be distributed face-to-face and increasingly via electronically mediated communication (SMS, MMS, email, forum discussions, blogs, social media, etc.). However, just as election folklore has found its way to computermediated communication in the last few decades, the online environment has at the same time inspired new folkloristic forms such as the internet meme. 
(3) As political elections (and their results) impact all Hungarian citizens, the potential exists for all Hungarian citizens to become involved as producers, consumers, and/or distributors of online election folklore as a form of political participation. Thus, the collection of relevant data on contemporary folklore simultaneously provides data on the folklore process: the creation, reception, transmission, and variation of this material across the internet. (4) Although serious research on digital folklore is rare and of rather varying quality in Hungary to date, the topic of popular political communication and folklore in a digital environment has received considerable attention and provides the background for this research.

This paper will outline the theoretical framework with basic concepts of online election folklore. It will draw attention to research conclusions on the online folklore of the 2002, 2006, and 2010 elections. And finally, it will present the findings on the 2014 online election folklore as illustrated by a representative sequence of campaign poster parodies.

\section{THEORETICAL FRAMEWORK AND BASIC CONCEPTS}

The study of online election folklore fits into the ever-changing concept of folklore as it draws on the traditional genres and texts of folklore (jokes, recruitment songs, and other short forms). Furthermore, key concepts of folklore studies, such as variation and adaptation, can be used to describe and interpret the new phenomena summed up under the umbrella term internet memes. Although examples themselves may be considered ephemeral, and even incomprehensible and irrelevant without contextual information, certain textual elements, motifs, formulas, plots, as well as visual patterns, etc., emerge again and again, serving as components in a line of tradition (cf. Blank \& Howard 2013).

Most internet folklore and humor is topical, addressing current issues and events of either local or global interest (Laineste 2002; Blank 2013). This intertwines with the concept of newslore, a term coined by Russell Frank (2004, 2011) to describe "folklore that comments on, and is therefore indecipherable without knowledge of, current events" (Frank 2011: 7). Newslore takes multiple forms including "jokes; urban legends; digitally altered photographs; mock news stories; ...; parodies of songs, poems, political and commercial advertisements, and movie previews and posters" (Frank 2011: 7). Election folklore fits perfectly into the concept of newslore; it is formulated topically, integrates popular reactions to the events and issues of the political campaign preceding the elections, and refers to the parties and individuals involved in it. 
Most examples of online election folklore are humorous and can thereby be interpreted in the framework of political humor. According to the new Encyclopedia of Humor Studies, political humor is an umbrella term in which "[p]olitics refers broadly to social behaviors related to the governing bodies of a nation or comparable entity. Political humor, then, encompasses humor directed at or derived from politics, policies, political parties, institutions, and individuals involved in the political process, as well as humor used by politicians themselves" (Bippus 2014: 585). Tsakona and Popa stress building on the interplay of text and context, saying that "political humour usually does not inform the audience on political issues, but explicitly comments on them, and conveys critical stance towards certain political acts and figures" (Tsakona \& Popa 2011: 8-9). In the case of election humor, the most important contextual element is the official political campaign itself, including the participating parties, their candidates, the campaign events and messages, and the various issues that occur throughout the campaign period (scandals, corruption, inappropriate behavior of politicians, etc.).

\section{RESEARCH METHODS AND BACKGROUND}

Due to the rapid developments within the online community, both in terms of technology and content, which impacts user interaction, the research methods used in this study could be considered somewhat experimental. ${ }^{1}$ The first research phase consisted of a detailed examination of the existing studies on the digital election folklore of the Hungarian parliamentary elections of 2002, 2006, and 2010. The second research phase consisted of collecting live online folklore during the 2014 election campaigns beginning in February 2014 through to the European Parliament elections on May 25. This phase involved gathering online folklore, monitoring relevant sites (blogs, tweets, commentary, etc.), and closely following online reactions to specific events, slogans, and other campaign texts (on methodology see Radchenko 2013; Domokos 2014).

\section{Previous research and findings on digital election folklore in Hungary between 2002 and 2010}

Hungarian scholars of communication, media studies, and political science consider 2002 a turning point in the use of online communication during elections, as well as its study. In 2002, "informational technologies as postmodern campaign tools" were introduced to Hungarian political campaigns as an 
innovation (Dányi 2002: 23). This, however, meant primarily one-way content supply: messages being sent from the parties or politicians to voters. At the same time, following the first round of parliamentary elections, electronic communication took on a different role. Activists and supporters of the governing party, struck by the unexpected results that eventually led to the victory of the left-wing opposition, made a desperate attempt to regain their position by sending a large number of official campaign messages and related folkloristic content via SMS and email. ${ }^{2}$

An online archive was immediately set up by the Open Society Archives (OSA) at Central European University, Budapest, collecting “... electronic campaign mail, [and] inviting all recipients of email and cell phone text messages related to the parliamentary elections to forward them to designated accounts. A large number of people responded by forwarding messages supporting, criticizing, accusing, or parodying the parties and candidates standing for election" (Székely 2008: 308; see also http://www.osaarchivum.org/hu/projects).

The incoming messages recorded from April 10 to May 10, 2002, and the online archive containing 900 emails and 185 SMSs is, to date, accessible in Hungarian, ${ }^{3}$ with a selection of texts translated into English. ${ }^{4}$ A sizeable group of texts included humorous political rhymes, up-to-date political adaptations, and parodies of classic poems (Sükösd \& Dányi 2002: 289-290). This "election folklore" was studied by folklorists who attempted to outline their main genres: jokes, proverbs, paraphrases, prophecy parodies, rumors and rumor parodies, catchwords, and election rhymes (Balázs 2004; Nagy 2005; Povedák 2014). One scholar stressed that these texts are "folklore creations in the strictest sense of the word in contrast to mass culture since they are both expressions of a community with the power to form a community" (Povedák 2014: 167), and further argued that they express an independent and contemporary folk culture.

Researchers expected that the formation of digital election folklore as a popular reaction to the election campaign was in line with technological progress, and were prepared to archive and study it in subsequent elections, but the material collected in 2006 and 2010 was significantly scantier and excited less research interest (Povedák 2014: 167). These materials also became significantly more visual (cf. Baran 2012).

In 2006, the OSA Archivum "reopened its archive of electronic campaign letters, again inviting recipients of electronic messages related to the new parliamentary elections to forward these messages". ${ }^{5}$ However, the number of messages forwarded to the OSA decreased significantly as compared to 2002 . The SMS as a medium virtually disappeared as visual emails (with pictures attached or embedded) came to replace text messages. The quality of these digitally modified pictures improved significantly, in some cases reaching a professional 
level (Székely 2008: 313). ${ }^{6}$ Most of them were modified versions of official campaign posters, some conveying political messages, others just making fun of them (Bodoky 2006). ${ }^{7}$

In 2010, online political communication was significantly present in the campaigns of political parties, and included the use of personal blogs and YouTube videos, but social media and microblogging (e.g. Twitter) were not yet effectively used (Burján 2010a, 2010b). The OSA did not resume the collection and study of campaign messages. Digitally modified, mock election posters were collected on a communal blog called "Vote-o-shop: retouched campaign 2010", wherein technical support was also offered to those intending to contribute, making it a kind of participatory archive.

\section{ONLINE FOLKLORE OF THE 2014 PARLIAMENTARY ELECTIONS IN HUNGARY}

The expansion of internet services and mobile internet in the few years leading up to the 2014 election $^{9}$ inevitably played an important role in the more intensive online presence and activity of political parties and individual politicians on various platforms of online media. The first part of the 'fieldwork' for this study involved monitoring three of the most widely read Hungarian news portals (index.hu, origo.hu, hvg.hu), their blogs and social media sites throughout the research period to gain an overall impression of the campaign, main figures, events, issues, etc., and to track vernacular responses and various forms of online election folklore. We also monitored the official Facebook pages of the incumbent prime minister, Viktor Orbán, and the contending prime minister candidates (Attila Mesterházy, Gábor Vona, Gordon Bajnai), as well as the political parties or groups of supporters involved in their campaigns. The second, more intensive part of the research included selecting significantly popular or variable text and meme types, and determining which political issues were the main sources of internet humor in connection with the campaign. These materials include examples of traditional folklore genres (e.g. jokes and humorous modifications of folk songs), ${ }^{10}$ but contemporary, online election folklore operates predominantly with new genres or forms summed up under the heading "internet memes". This category, used both by researchers and online "prosumers", sums up "images, videos, audios, and hyperlinks with humorous content, which are created by individuals with online access and easy-to-use software", which are "often employed as a form of political and social participation" (Shifman 2014: 392). ${ }^{11}$ 
Here, we focus on one type of internet meme: digitally modified images or image macros (Rutkoff 2007). In this research these are mostly modifications of campaign posters that contradict the statements, messages and achievements of the official campaign, producing incongruity by changing the picture, the text, or both, and thus being humorous. But such modifications are not always "folkloristic". Official campaign posters can also mock the opponents, expressing criticism of their statements or actions. In this case they have a direct political goal of influencing voters, primarily by casting their opponents in a negative light. The situation is further complicated in the case of poster parodies created by supporters of a political party that later become incorporated in official or semi-official political communication, for example, when such posters are distributed on the official Facebook page of a political party. The following modification of a film poster provides an example of the merger of official and vernacular political communication.

The original poster for the film released in Hungarian cinemas on February 13, 2014 (Fig. 1), advertises a romantic comedy whose title alludes to sexuality "To Knock Down Tímea Hajnal". The creator of the parody poster (Fig. 2), a supporter of the liberal coalition Együtt-PM, modified a number of the original poster's textual and visual details. In the parody poster, the

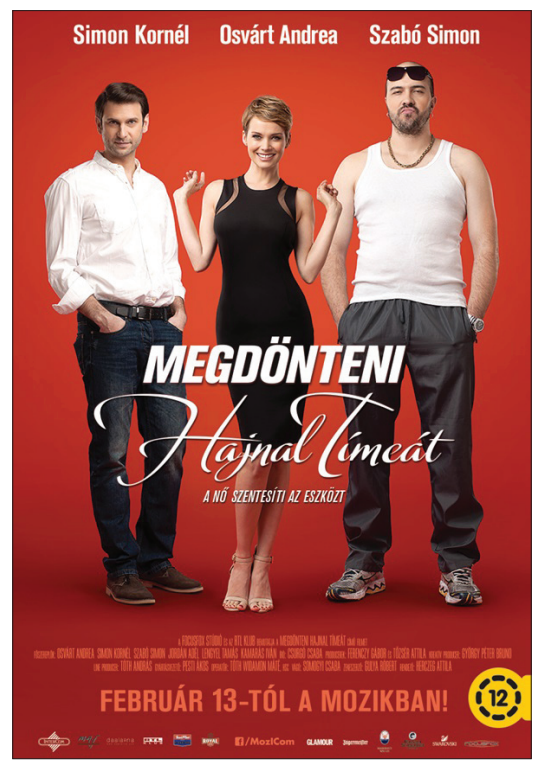

Figure 1. Source: http: / / filmbook. blog.hu/2014/02/10/megdonteni_ hajnal_timeat_671/, last accessed on 25 September 2018.

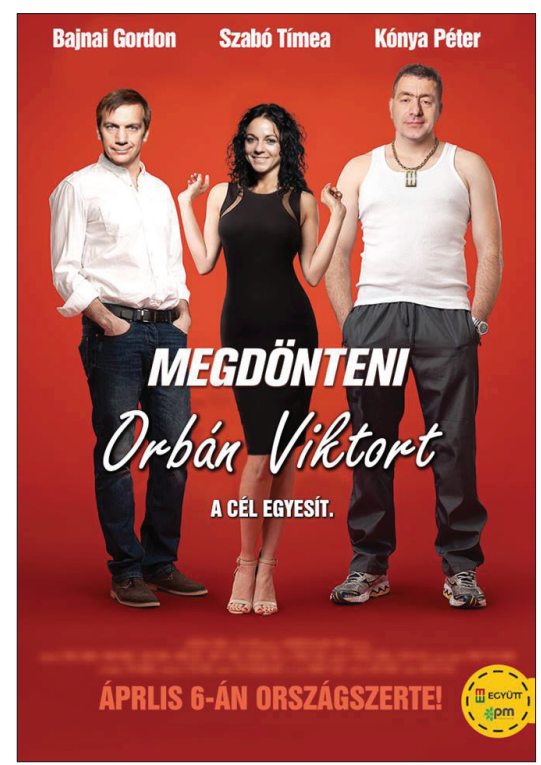

Figure 2. Source: http://444. hu /2014/02 / 14 / az-ellenzek-elveszitetteaz-eszet, last accessed on 25 September 2018. 
title and the proverbial slogan ("The goal sanctifies the means") was changed to a political message: "To knock down Viktor Orbán. The goal unites". The poster substitutes the faces and names of leading actors with those of leading liberal candidates. Furthermore, the film's release date was changed to that of the parliamentary elections. The parody poster's image soon appeared on the official Facebook page of the political party, Együtt 2014 (Together 2014), and was used as an unofficial campaign poster.

A noticeable feature of the gathered 2014 campaign folklore as well as the official campaign was personalization. As István Povedák states:

Contemporary political style is increasingly dominated by tabloidization and personalization. This includes a focus on the leader [i.e. political leader], which is characterized not only by the fact that political messages shift rather from organizations to individuals, but also by popularization, that is the representation of political events through the lives of ordinary people. (Povedák 2014: 153)

One example that has inevitably influenced the strategies of Hungarian parties is the 2008 online campaign of Barack Obama, which utilized online tools (social media, paid bloggers, email communication, and YouTube videos) to effectively convey his message, and his 2012 campaign which mobilized activists of online networks (Merkovity 2009; Takaragawa \& Carty 2012; Hong \& Nadler 2012; on the folkloristic aspects of the US election campaign see Duffy \& Teruggi Page \& Young 2012; on the 'LOLitics' of the 2012 election see Tay 2014).

During the 2014 Hungarian election campaigns, the most popular target of election humor was undoubtedly Viktor Orbán, who, as head of Fidesz, the governing party, served as Hungary's prime minister from 1998 to 2002, and again from 2010 to the present. Because of his political role, his leadership style, and his personality, a considerably rich folklore has developed around him throughout the past seventeen years (see Povedák 2011: 159-175; for a detailed analysis of Viktor Orbán as a hero of contemporary folklore see Povedák 2014). Opinion polls have shown that Viktor Orbán's popularity significantly exceeds the popularity of his political party, hence the Fidesz campaign in 2014 was based personally on the prime minister.

The personalization and tabloidization accompanying the campaign period can be illustrated by the example of the pink couch. The original image (Fig. 3) comes from a photoshoot for a tabloid magazine in which Viktor Orbán and his family participated. It was originally published on the official Facebook page of the prime minister, and led to numerous parodies referencing popular culture: the couch and Orbán depicted jointly as a product in an IKEA catalogue (Fig. 4); the couch inserted in a frame of the American television show, 
Friends, with members of the governing party, Fidesz, taking on the main roles (Fig. 5). Another poster parody conveyed a direct political message in support of the left-wing party, MSZP, by placing politicians and other commonly known personalities linked to the Fidesz campaign, who had been involved in controversial issues or scandals during the campaign period, on the couch (Fig. 6).

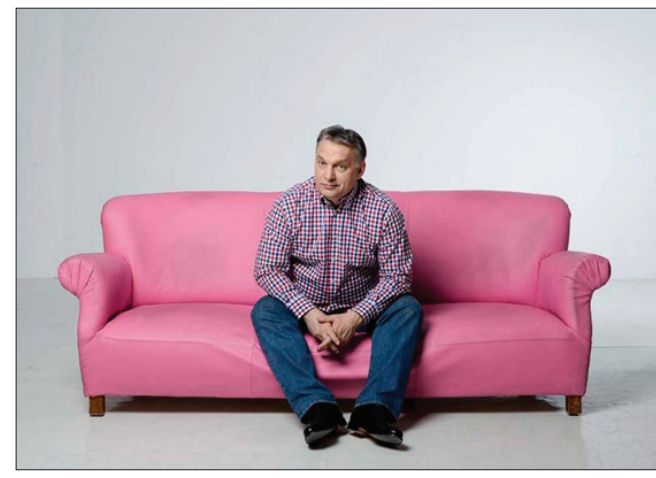

Figure 3. Source: http://hvg.hu/ itthon /20140331_Foto_Orban_Viktor_ tudja_fokozni, last accessed on 25 September 2018.

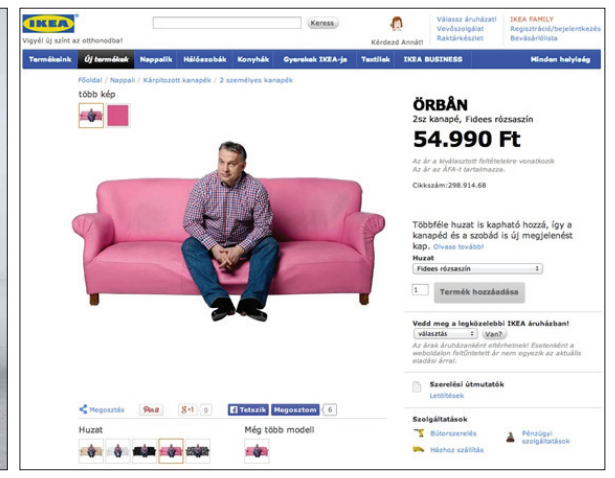

Figure 4. Source: http://hvg.hu/ velemeny/20140331_Fotok_Orban_Putyin_ vallan_pihen_avagy_bei, last accessed on 25 September 2018.
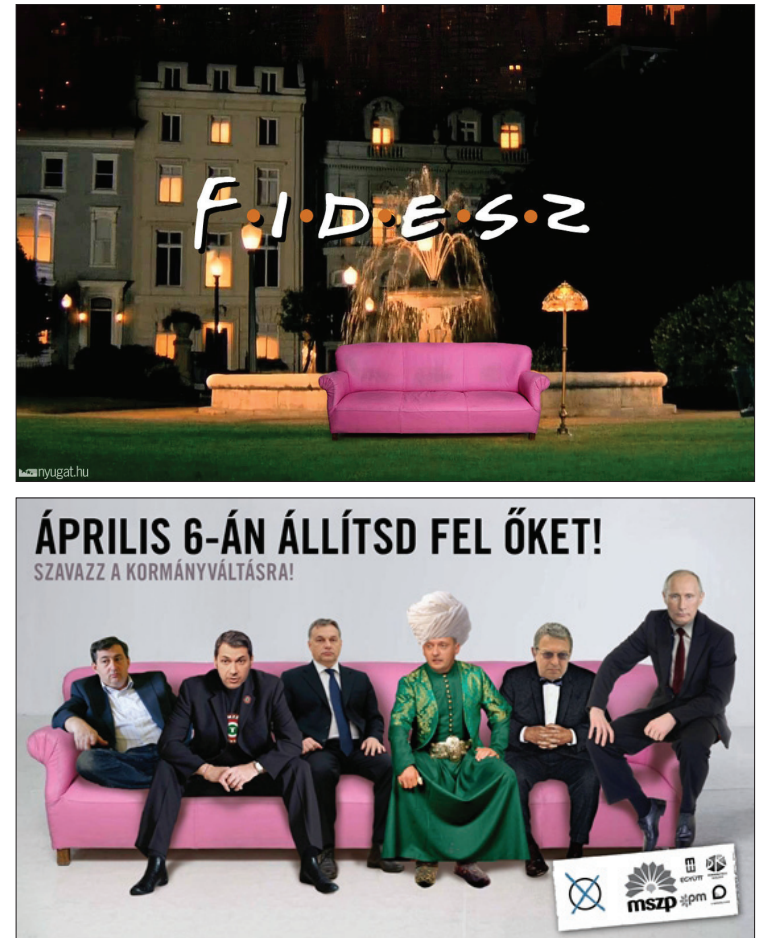

Figure 5. Source: http://www. nyugat.hu/tartalom / cikk/ orbaneknal_mar_rozsaszin_az_elet_ egy_kanapeban, last accessed on 25 September 2018.

Figure 6. Source: http://hvg.hu/ velemeny/20140402_Fotok_Rogan basa_Cili_es_a_Baratok_kozt_, last accessed on 25 September 2018. 


\section{The Prime Minister of Hungary}

The last part of this paper focuses on one sequence of variants as a representative example of the online folklore of the 2014 elections in Hungary. The numerous variants were based on a campaign poster for the incumbent prime ministerial candidate, Victor Orbán, of the governing party, Fidesz (Fig. 7).

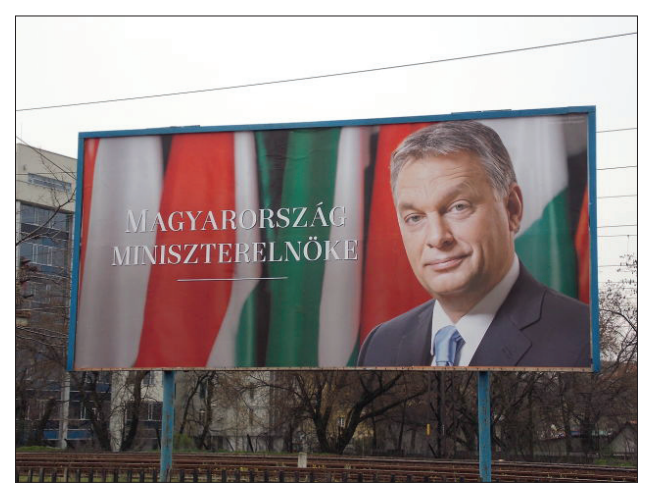

Figure 7. Source: http://hvg.hu/velemeny/20140317 Mem_orban_plakat, last accessed on 25 September 2018.

The poster consists of three main elements: a portrait of Viktor Orbán, a simple text in white, saying "The prime minister of Hungary", and Hungarian national flags in the background. Although this was the main campaign poster for Fidesz, it did not contain any concrete reference to the political party, the person in the picture or the election at all. The simple poster with a very simple message provided a blank canvas on which 'online folk artists' could create a vast number of variations by changing one or more of the three elements listed above.

One group of these poster parodies changed only the text to contradict the original message by adding the date of the elections "Prime minister of Hungary - until the 6th of April" (Fig. 8). Other modifications used wordplay or puns to considerably modify the meaning with only minor changes in the wording. Adding a definite article and changing a single letter in one word changes "Magyarország miniszterelnöke" (Prime Minister of Hungary) into "Magyarország a miniszterelnöké" (Hungary is the property of the Prime Minister), an ironic reference to the centralization accomplished by the government between 2010 and 2014 (Fig. 9). The last example of this type of poster adaptation shows the original text has been changed to the quote, "Big Brother is watching you" from George Orwell's novel 1984 (Fig. 10). 

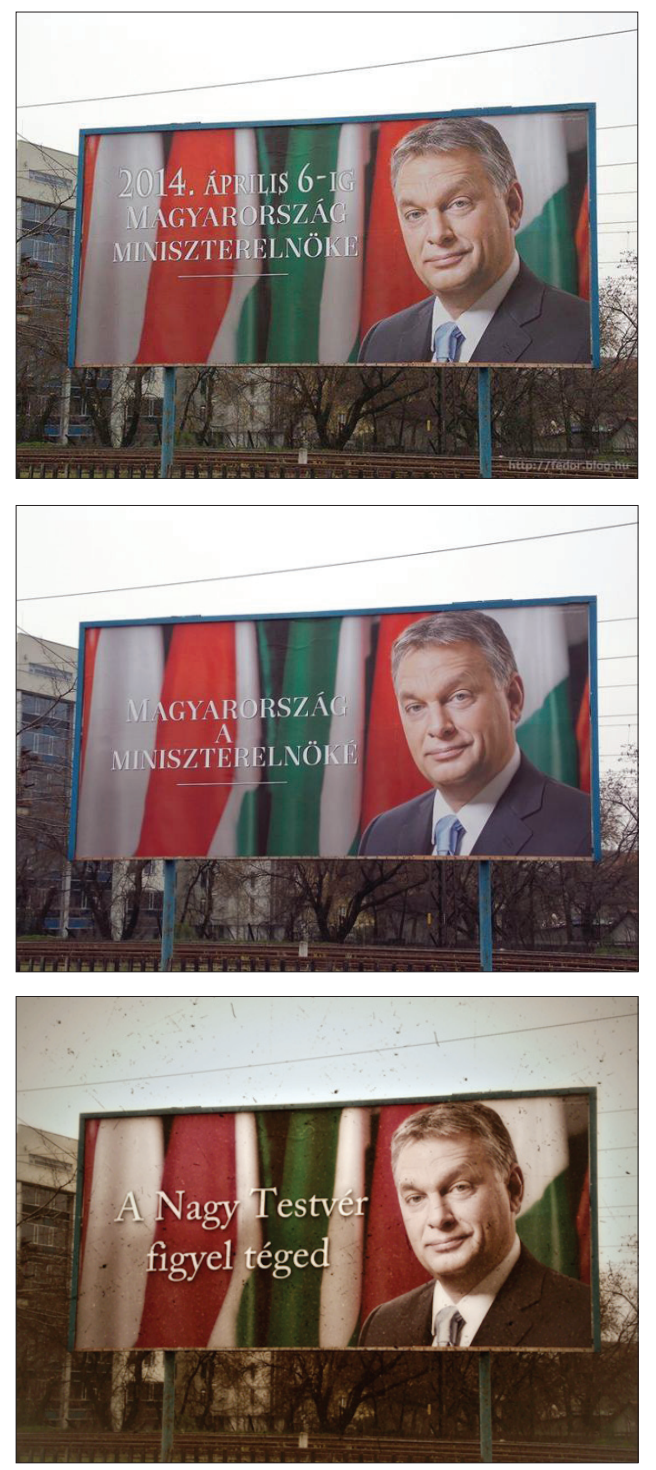

Figure 8. Source: https://www.facebook. com $/$ photo. php?fbid $=573626526077714 \& s$ et $=a .164881300285574 .35644 .1147354653$ 00158\&type $=1 \&$ theater, no longer available.

Figure 9. Source: http://szarvas.tumblr. com / image / 79814367340, last accessed on 25 September 2018.

Figure 10. Source: http://galeria. index.hu/tech / 2014/03/17/orban_a_ fonok_a_memeskutban /4, last accessed on 25 September 2018.

Another group of examples uses only visual modifications, changing the portrait and/or the background, to achieve incongruity. Several of these examples refer to Viktor Orbán's leadership style by substituting his portrait with those of Hungarian political leaders from the totalitarian regime, e.g. János Kádár (Fig. 11) and Ferenc Szálasi (Fig. 12), as well as the current Russian president Vladimir Putin (Fig. 13). 
Figure 11. Source: http: / fideszfigyelo. blog.hu/2014/03/16/vegre_kiderult_hogy_ mi_a_fidesz_programja, last accessed on 25 September 2018.

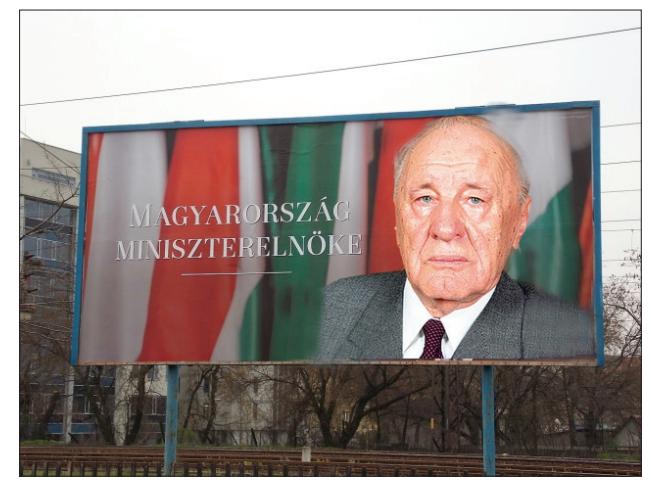

Figure 12. Source: http://galeria. index.hu/tech / 2014/03/17/orban_a_ fonok_a_memeskutban /3, last accessed on 25 September 2018.

Figure 13. Source: http://csattogoslepke. tumblr.com/post/79807609381, no longer available.
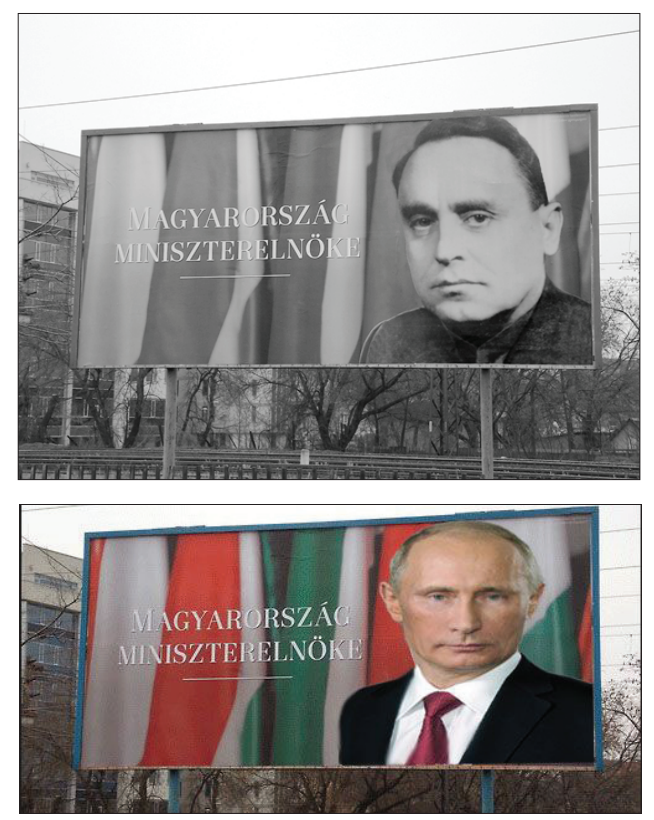

By modifying both the textual and visual content, parodies can convey a more complex message or more specific reference to current events. But they can also shift the context from direct political content to other phenomena of popular culture, with (often nonsensical) humor (cf. Bodoky 2006: 31). One poster shows Mr. Bean in Orbán's place, with the text "The prime minister of Hungary. The ultimate disaster" (Fig. 14). The creator of the poster parody refers to a popular comedian of that time, and also expresses his political views. Another poster replaces Orbán's portrait with that of Jimi Hendrix, with text stating that "This is not the prime minister of Hungary" (Fig. 15) - a message as simple as the original. 

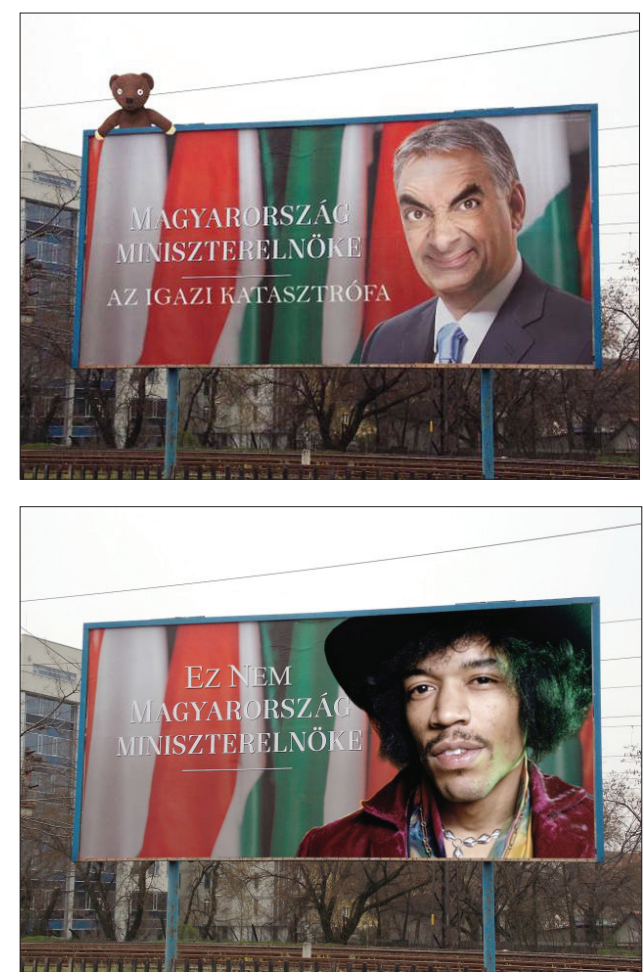

Figure 14. Source: http://cink.hu/ magyarorszag-miniszterelnoke-2-1545105733, last accessed on 25 September 2018.

Figure 15. Source: http: / / pauszkoepkoedoe. tumblr.com / post / 79804142656 / tegyuktisztaba-a-gyereket, no longer available.

Following their success in the parliamentary election, Fidesz repurposed the posters (shown in Fig. 7) for the European Parliament campaign by pasting a new text over the old one: "Let's tell Brussels: Respect the Hungarians!", and adding the logos of Fidesz and KDNP (Fig. 16).

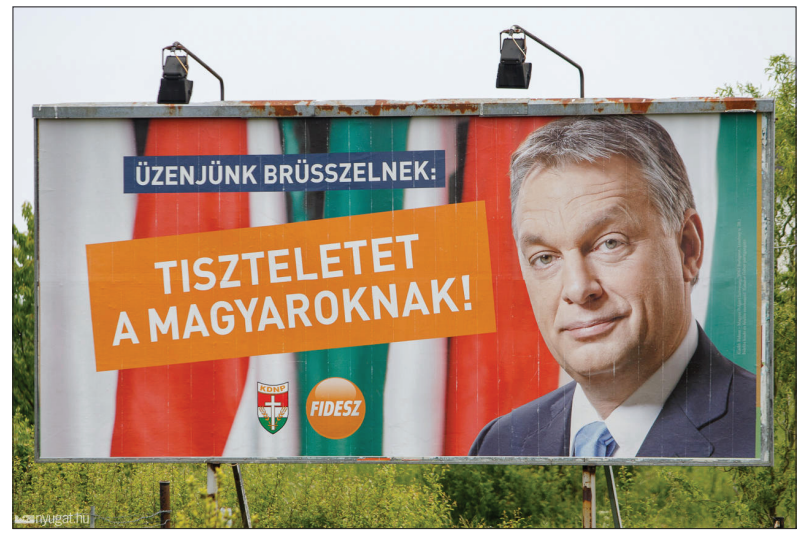

Figure 16. Source: http://www.nyugat.hu/tartalom/cikk/eu_indian_ bajnai_gyikmosolyu_orban, last accessed on 25 September 2018. 
The renewed posters inspired a new, even stronger wave of modifications, traces of which can still be observed today. The message (and sometimes the addressee) was changed in many ways, for example, suggesting telling Brussels (and thus the European Union) to "[s]end more money". ${ }^{12}$ The poster became an internet meme, stimulating official and popular, political and non-political responses. Even after the elections a meme generator was set up for a few months to allow the user to change the message and addressee of the original poster by filling in two text-boxes. These poster modifications could be distributed with a link to the generator. ${ }^{13}$ The slogan "Respect the Hungarians" became proverbial, inspiring paraphrases, wordplay, and jokes.

More recent political events underline that a year later, the poster and slogan, "Respect the Hungarians", are still known and can serve as a point of reference available for further variation. On May 22, 2015, Jean-Claude Juncker, president of the European Commission and former prime minister of Luxembourg, called Hungary's prime minister a dictator and playfully slapped him in the face during a press photoshoot at the Riga Summit. ${ }^{14} \mathrm{~A}$ vernacular reaction - in the form of an animGIF - was born within 24 hours (Fig. 17). Together with the inserted video, the original message - asking for more respect from the European Union - gained an entirely new meaning.

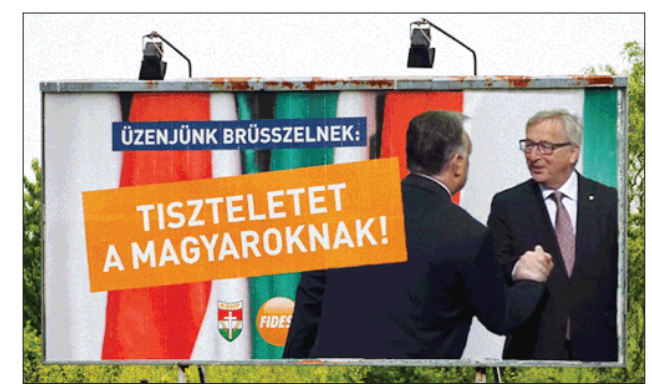

Figure 17. Source: http:/ / sailorripley.tumblr.com / post/119630799351/ most-mar-tenyleg-hadat-kellene-uzenni-az-unionak, last accessed on 25 September 2018. 


\section{CONCLUSIONS}

This paper presented a case study on contemporary folklore in an electronic environment, examining material that was created during the campaign period preceding the 2014 elections in Hungary. Most of the collected 'online election folklore' cannot be placed in any of the traditional folklore genres, but is rather a popular reaction to the campaign in a visual form, most often an image macro. Although examples themselves may be considered ephemeral, and even incomprehensible and irrelevant without contextual information, certain textual elements, motifs, formulas, plots, as well as visual patterns, etc. emerge over and over again, serving as components in a line of tradition.

\section{NOTES}

1 This paper is based on research conducted together with my colleague, Mariann Domokos. A longer research paper addressing the theoretical and methodological questions of studying online folklore has been published in Hungarian (Domokos \& Vargha 2015).

${ }^{2}$ For example: "Viktor Orbán writes: We need more for the fight. / When next we hear the call, / In line we all must fall! / Long live our homeland! / Pass it on to five patriots" (Povedák 2014: 167). This text is based on the Kossuth song, a folk song over 150 years old, with more than 600 variants known from oral distribution. On its use and innovative variants referring to daily politics see Domokos \& Vargha 2015: 151-154.

${ }^{3}$ See http://kampanyarchivum.osaarchivum.org/kampany02/list.php, last accessed on 16 October 2018.

4 See http://kampanyarchivum.osaarchivum.org/eng.html, last accessed on 16 October 2018 .

5 See http://www.osaarchivum.org/hu/projects, last accessed on 15 October 2018.

6 The 2006 messages are available on the following website: http://kampanyarchivum. osaarchivum.org/kampany06/list.php, last accessed on 16 October 2018.

7 Tamás Bodoky, researcher of media studies, analyzed 567 campaign poster parodies archived from the sg.hu forum titled "We Photoshop worse than four years ago", alluding to the Fidesz campaign slogan: "We live worse than four years ago" (Bodoky 2006). The forum itself is no longer available.

8 See http://voteoshop.blog.hu/, last accessed on 25 September 2018. Administrators of the blog identified it as a resumption of the 2006 forum "We Photoshop worse than four years ago", containing "honest and/or funny versions of campaign posters, films and other political advertisements". 
9 In Hungary, with a population of nearly 10 million people, the number of internet subscriptions was roughly 2.8 million at the end of 2009 (see https://www.ksh.hu/docs/ eng/xstadat/xstadat_annual/i_oni001.html, last accessed on 25 September 2018). By the end of the first quarter of 2014, the number of subscriptions exceeded 6.6 million; the most dynamically expanding area is mobile internet with over 4 million subscriptions (see https://www.ksh.hu/docs/hun/xstadat/xstadat_evkozi/e_oni001.html, last accessed on 25 September 2018). Detailed data can be found on the website of the Hungarian Central Statistical Office (see http://www.ksh.hu/?lang=en, last accessed on 25 September 2018).

${ }^{10}$ Although the most traditional, and, for over a century, the most common and popular genre of political humor is the political joke used extensively to comment on political issues, political figures and parties, we came across very few political jokes regarding the 2014 election in our online research.

${ }^{11}$ Merrill Kaplan gives the following definition of the meme as a genre: "On the Internet, meme has become a genre term, albeit a broad one. Meme may refer to nearly any creation or practice that has 'gone viral', in which it is transmitted, transformed, and retransmitted quickly and widely enough across the Internet and other new media outlets to have attained status as a familiar cultural reference online. Examples may include catchphrases, edited photographs, image macros, and pranks" (Kaplan 2013: 136).

${ }^{12}$ See http://pontosan-ahogy.tumblr.com/post/84523048470/az-eredeti-se-rossz-magyarisztantumblr-com, last accessed on 25 September 2018.

${ }^{13}$ See http://hvg.hu/tudomany/20140527_uzenjen_on_is_itt_a_fidesz_generator, last accessed on 25 September 2018.

${ }^{14}$ See http://www.bbj.hu/politics/juncker-calls-orban-dictator-slaps-him_98018; video available at http://coub.com/view/6jhry, both last accessed on 25 September 2018.

\section{REFERENCES}

Balázs, Géza 2004. Választási sms-ek folklorisztikai-szövegtani vizsgálata. [FolkloristicTextological Study of Campaign SMSs.] Magyar Nyelvór, Vol. 128, No. 1, pp. 3653. Available at http://www.c3.hu/ nyelvor/period/1281/128104.pdf, last accessed on 25 September 2018.

Baran, Anneli 2012. Visual Humour on the Internet. In: Liisi Laineste \& Dorota Brzozowska \& Władisław Chłopicki (eds.) Estonia and Poland: Creativity and Tradition in Cultural Communication. Vol. 1. Jokes and Their Relations. Tartu: ELM Scholarly Press, pp. 171-186. DOI: 10.7592/EP.1.baran.

Bippus, Amy M. 2014. Political Humor. In: S. Attardo (ed.) Encyclopedia of Humor Studies. Los Angeles: SAGE, II, pp. 585-588. http://dx.doi.org/10.4135/9781483346175. n259.

Blank, Trevor J. 2013. The Last Laugh: Folk Humor, Celebrity Culture, and MassMediated Disasters in the Digital Age. Madison: University of Wisconsin Press. 
Blank, Trevor J. \& Howard, Robert Glenn (eds.) 2013. Tradition in the Twenty-First Century: Locating the Role of the Past in the Present. Logan, Utah: Utah State University Press.

Bodoky, Tamás 2006. Többet retusálunk, mint négy éve. Választási kampányplakátok az interneten. [We Rethink More Than Four Years Ago: Election Campaign Posters on the Internet.] Médiakutató, Vol. 7, No. 2, pp. 7-31. Available at http:// www.mediakutato.hu/cikk/2006_02_nyar/01_tobbet_retusalunk, last accessed on 25 September 2018.

Burján, András 2010a. Internetes politikai kampány. [Political Campaign on the Internet.] Médiakutató, Vol. 11, No. 3, pp. 93-103. Available at http://www. mediakutato.hu/cikk/2010_03_osz/08_internet_kampany/?q=kampány\#kampány, last accessed on 25 September 2018.

Burján, András 2010b. Internetes politikai kampány 2. [Political Campaign on the Internet 2.] Médiakutató, Vol. 11, No. 4, pp. 37-50. Available at http://www.mediakutato. hu/cikk/2010_04_tel/03_internet_politika_kampany/?q=kampány\#kampány, last accessed on 25 September 2018.

Dányi, Endre 2002. A faliújság visszaszól. Politikai kommunikáció és kampány az interneten. [Political Communication and Campaign on the Internet.] Médiakutató, No. 7, pp. 23-36. Available at http://www.mediakutato.hu/cikk/2002_02_nyar/02_ faliujsag_visszaszol/?q=kampány\#kampány, last accessed on 25 September 2018.

Domokos, Mariann 2014. Towards Methodological Issues in Electronic Folklore. Slovenský Národopis, Vol. 62, No. 2, pp. 283-295. Available at http://www.uet.sav.sk/files/ etno2-text-web-27-6.pdf, last accessed on 25 September 2018.

Domokos, Mariann \& Vargha, Katalin 2015. Elektronikus választási folklór 2014. [Digital Folklore of Political Elections in Hungary 2014.] Replika, No. 90-91, pp. 141-169. Available at http://www.replika.hu/system/files/archivum/90-91_09_domokos_vargha.pdf, last accessed on 25 September 2018.

Duffy, Margaret \& Teruggi Page, Janis \& Young, Rachel 2012. Obama As Anti-American: Visual Folklore in Right-Wing Forwarded E-mails and Construction of Conservative Social Identity. Journal of American Folklore, Vol. 125, No. 496, pp. 177-203. http://dx.doi.org/10.5406/jamerfolk.125.496.0177.

Frank, Russell 2004. When the Going Gets Tough, the Tough Go Photoshopping: September 11 and the Newslore of Vengeance and Victimization. New Media \& Society, Vol. 6, No. 5, pp. 633-658. http://dx.doi.org/10.1177/146144804047084.

Frank, Russell 2011. Newslore: Contemporary Folklore on the Internet. Jackson: University Press of Mississippi.

Hong, Sounman \& Nadler, Daniel 2012. Which Candidates Do the Public Discuss Online in an Election Campaign? The Use of Social Media by 2012 Presidential Candidates and Its Impact on Candidate Salience. Government Information Quarterly, Vol. 29, No. 4, pp. 455-461. Available at https://www.sciencedirect.com/journal/governmentinformation-quarterly/vol/29/issue/4, last accessed on 25 September 2018.

Kaplan, Merrill 2013. Curation and Tradition on Web 2.0. In: Trevor J. Blank \& Robert Glenn Howard (eds.) Tradition in the Twenty-First Century: Locating the Role of the Past in the Present. Logan, Utah: Utah State University Press, pp. 123-148. Available at http://muse.jhu.edu/book/23562, last accessed on 25 September 2018. 
Laineste, Liisi 2002. Take It with a Grain of Salt: The Kernel of Truth in Topical Jokes. Folklore: Electronic Journal of Folklore, Vol. 21, pp. 7-25. http://dx.doi. org/10.7592/FEJF2002.21.jokes.

Merkovity, Norbert 2009. Barack Obama elnöki kampányának sajátosságai. [Particularities of the Presidential Campaign of Barack Obama.] Médiakutató, Vol. 10, No. 1, pp. 97-106. Available at http://epa.oszk.hu/03000/03056/00034/ EPA03056_mediakutato_2009_tavasz_08.html, last accessed on 25 September 2018 .

Nagy, Ilona 2005. Folklór „in statu nascendi”: Magyar választások 2002-ben. [Folklore "in statu nascendi": Hungarian Elections in 2002.] In: István Csörsz Rumen (ed.) Mindenes gyújtemény I. Tanulmányok Küllós Imola 60. születésnapjára. Artes Populares 21. Budapest: ELTE BTK Folklore Tanszék, pp. 465-471. Available at http://real.mtak.hu/25578/1/ArtesPopulares_21.pdf, last accessed on 25 September 2018.

Povedák, István 2011. Álhôsök, hamis istenek? Hôs- és sztárkultusz a posztmodern korban. [Pseudo-Heroes, False Gods: Hero and Star Cult in the Postmodern Age.] Szeged: Gerhardus. Available at http://www.academia.edu/7270209/, last accessed on 25 September 2018.

Povedák, István 2014. One from Us, One for Us: Viktor Orbán in Vernacular Culture. In: István Povedák (ed.) Heroes and Celebrities in Central and Eastern Europe. Szeged: Department of Ethnology and Cultural Anthropology, pp. 153-171. Available at http://www.academia.edu/7204198/, last accessed on 25 September 2018.

Radchenko, Daria 2013. "Ishchite nas cherez Iandeks": metodiki i problemy sbora setevogo fol'klora. ["Search for Us through Yandex": Methodology and Problems of Collecting Online Folklore.] Tautosakos darbai / Folklore Studies, Vol. 45, pp. 116-131. Available at http://www.llti.lt/failai/10_Radcenko(1).pdf, last accessed on 25 September 2018.

Rutkoff, Aaron 2007. With 'LOLcats' Internet Fad, Anyone Can Get In on the Joke. The Wall Street Journal, August 25. Available at https://www.wsj.com/articles/ SB118798557326508182, last accessed on 25 September 2018.

Shifman, Limor 2014. Internet Humor. In: S. Attardo (ed.) Encyclopedia of Humor Studies. Los Angeles: SAGE, I, pp. 389-393. http://dx.doi.org/10.4135/9781483346175. $\mathrm{n} 180$.

Sükösd, Miklós \& Dányi, Endre 2002. M-politika akcióban. SMS és e-mail a 2002-es magyarországi választási kampányban. [SMS and E-mail in the 2002 Hungarian Election Campaign.] In: Nyíri Kristóf (ed.) Mobilközösség - mobilmegismerés. Budapest: MTA Filozófiai Kutatóintézete, pp. 273-293. Available at http://www. mta.t-mobile.mpt.bme.hu/dok/3_suk-dany.pdf, last accessed on 26 September 2018.

Székely, Iván 2008. Elektronikus kampánylevél-archívum: A hálózatelemzés lehetôségei. [Archives of Electronic Campaign Letters: Possibilities of Network Analysis.] In: Jolán Róka (ed.) Academia Budapestiensis Communicationis et Negotii: Annales, Tomus I. pp. 307-316. Budapesti Kommunikációs és Üzleti Fóiskola. Available at https://anzdoc.com/elektronikus-kampanylevel-archivum-a-halozatelemzeslehetseg.html, last accessed on 26 September 2018. 
Takaragawa, Stephanie \& Carty, Victoria 2012. The 2008 U.S. Presidential Election and New Digital Technologies: Political Campaigns as Social Movements and the Significance of Collective Identity. Tamara: Journal for Critical Organization Inquiry, Vol. 10, No. 4, pp. 73-89. Available at https://tamarajournal.com/ index.php/tamara/article/view/114/pdf_7, last accessed on 26 September 2018.

Tay, Geniesa 2014. Binders Full of LOLitics: Political Humour, Internet Memes, and Play in the 2012 US Presidential Election (and Beyond). European Journal of Humour Research, Vol. 2, No. 4, pp. 46-73. http://dx.doi.org/10.7592/EJHR2014.2.4.tay.

Tsakona, Villy \& Popa, Diana E. 2011. Humour in Politics and the Politics of Humour: An Introduction. In: Villy Tsakona \& Diana E. Popa (eds.) Studies in Political Humour. Amsterdam \& Philadelphia: John Benjamins, pp. 1-30. 


\title{
GAY CLOWNS, PIGS AND TRAITORS: AN EMOTION ANALYSIS OF ONLINE HATE SPEECH DIRECTED AT THE SWEDISH- SPEAKING POPULATION IN FINLAND
}

\author{
Karin Sandell \\ PhD Student in Nordic Folkloristics, Abo Akademi University, Finland \\ Researcher for the Committee for Ethnology and Folkloristics \\ Society of Swedish Literature in Finland \\ e-mail: karin.sandell@abo.fi
}

\begin{abstract}
The article deals with the emotion analysis of online hate speech, studying the way that emotions are performed in online hate speech directed at the Swedish-speaking population in Finland. The material originates from the public debate forum Suomi24. In analysing the forum posts, I intend to show how hatemongers use emotional words, emotive expressions and metaphors referring to the Finnish national awakening and how this is connected to the populist discourse of today. As a result, three categories of hate speech emerge from the material: suspicion, demasculinization, and dehumanization.
\end{abstract}

Keywords: dehumanization, demasculinization, emotions, Finland, online hate speech, performativity, populism, suspicion, the Swedish-speaking population in Finland

\section{INTRODUCTION}

Gay clowns, pigs and traitors to the country - these are representations of three different categories of online hate speech directed at the Swedish-speaking population in Finland. The hate speech is exceedingly emotive and sprinkled with metaphors referring to nineteenth-century Finland.

The debate climate in Finland has become harsher and more populist in nature during the last years. Hatemongers, who one might picture lurking in the darker corners of the Internet, have stepped into the public debate, often anonymously, but also more and more frequently with their full name and picture. Unlike traditional trolls, they do not burst when exposed to light, rather they bask in the spotlight growling about their right to speak their mind in the name of free speech (Yle 2015; Pöyhtäri \& Haara \& Raittila 2013: 39-43). 
Over 90 percent of the Finns are of the opinion that deliberate provocation has increased in public debate, and more than half are so tired of the aggressive climate that they consider withdrawing completely from the debate (Pitkänen \& Westinen 2016: 6). The toughening of the debate climate coincides with increased support for the right-wing populist Finns Party, which in turn is part of the rise of populist radical right parties with anti-immigration agendas throughout Europe (Sakki \& Pettersson 2015; Jungar \& Jupskås 2014; Lähdesmäki \& Saresma 2014: 300). Along with the tougher debate climate, the occurrence of hate speech in Finland has increased during the recent years. According to a survey among the targeted groups, ${ }^{1}$ hostile speech and conduct have become more and more acceptable, while the will to resolve the problem has not increased. Minorities in Finland most often encounter harassment in public places and, secondly, on the Internet. The respondents have been verbally insulted, called names, shouted at, physically threatened or spat on. A majority of the respondents have been harassed up to ten times during the past year because they belong to a minority group (MoJ 2016).

About 5.5 percent of the Finnish population is Swedish-speaking and is one of the minority groups subjected to hate speech, both online and offline. In this article, I am focusing on online hate speech aimed at the Swedish-speaking population in Finland. Please note that I do not indicate that the majority of the Finnish-speakers partake in the hate speech directed at the Swedish-speaking population or any other group (Saukkonen 2011: 88-89).

Online hate speech is generally defined as hostile remarks directed at individuals and/or groups in the form of articles, comments, e-mails, blog posts and various discussions on the Internet.

[T]he term 'hate speech' shall be understood as covering all forms of expression which spread, incite, promote or justify racial hatred, xenophobia, anti-Semitism or other forms of hatred based on intolerance, including: intolerance expressed by aggressive nationalism and ethnocentrism, discrimination and hostility against minorities, migrants and people of immigrant origin. (Council of Europe 1997)

This recommendation, made by the Council of Europe's Committee of Ministers, applies particularly to hate speech spread through media, but does not define what kind of media. When using the terms 'hate speech' or 'online hate speech', I will be referring to the kind of hate-mongering that takes place on the Internet, if not stated otherwise.

According to folklorist Trevor Blank, the efficiency and anonymity of the Internet makes it an ideal channel for the transmission of folk narratives. The anonymity makes people more daring; instead of using circumlocution, they 
express their views more aggressively (Blank 2009: 9). Journalism scholar Melissa Wall compares the comment field to a virtual town hall, an open meeting on the Internet where the commentators have the possibility to be anonymous (Wall 2005: 163). Internet comments are often meant to be insignificant and not to be taken seriously, but one should remember that comments that remain online and open for everyone to see also have an influence on the public debate at large (Skogerbø \& Winsvold 2008: 41-43). The Internet is often looked upon as a democratic arena where everyone and anyone can have their say, but as journalist and author Lisa Bjurwald, among others, has pointed out, the users tend to read only what already confirms their view of the world (Bjurwald 2013). As noted by philosopher Martha C. Nussbaum, emotions such as disgust and envy can cause great damage, for instance when disgust is seen as a valid reason to discriminate against a group of people, especially if relied upon as guides in society and in the legislative process (Nussbaum 2013: 3). According to Reeta Pöyhtäri, Paula Haara, and Pentti Raittila at the Research Centre for Journalism, Media and Communication at the University of Tampere, aggressive speech may lead to a reduced variety of opinions due to an emotional atmosphere of hate and fear. They also call into question whether freedom of speech could be limited and to what extent, in case that freedom is used to offend and threaten people (Pöyhtäri \& Haara \& Raittila 2013). Øyvind Strømmen, journalist and author, has researched right-wing extremist online environments and analysed the ideologies behind Anders Behring Breivik's acts of terrorism. ${ }^{2}$ Strømmen's research shows a connection between online hate speech and the very tangible consequences it might have (Strømmen 2012).

The aim of this article ${ }^{3}$ is to study how emotions are performed in online hate speech directed at the Swedish-speaking population in Finland. The starting point of my analysis is the method for emotion analysis through figures of speech developed by Sara Ahmed, professor in Race and Cultural Studies, in The Cultural Politics of Emotion (2004) and utilized by Lena Marander-Eklund, professor of Nordic Folkloristics, in her article on the emotion analysis of postwar memories (2009). I will apply the method to material consisting of textual examples of online hate speech directed at the Swedish-speaking population. I intend to show how the hate speech of today - online - is connected to expressions of hatred in the past. 


\section{WHAT EMOTIONS DO}

The theoretical approach for this article is to view online hate speech as performative. Performativity, here defined as the performative capacity of speech and communication, turns the attention to what action the statement performs or consummates, not to the linguistic meaning (Butler 1993). I will examine how emotions are performed in the material by analysing the quotes, focusing on emotional words, emotive expressions and metaphors.

Emotions are performative and expressing them makes them 'real' (Ahmed 2004: 13). I align myself with Ahmed, who argues that our emotions toward an object originate from cultural conceptions. According to her, emotions are not something we have for an object; they are created in the encounter with the object (Ahmed 2004: 7). In other words, emotions are produced in the interaction between self and society, material settings, cultural symbols and so on, and are not simply shaped by interpersonal relations (Riis \& Woodhead 2010: 7). The researcher should therefore examine what emotions do, instead of asking what emotions are (Ahmed 2004: 7). Ahmed is critical of the model where emotions are regarded as psychological states. Instead, she introduces the sociality of emotion in terms of a model in which emotions are regarded as social and cultural practices. Ahmed names the psychological model of emotion the 'inside out' model of emotions; according to this model, a person has feelings that move outward towards objects and other people, and these feelings might return to the person in whom they originated (Ahmed 2004: 8-9). She changes the direction and suggests that feelings 'come from without and move inward' (Ahmed 2004: 9). She exemplifies this with the feeling of grief felt by a whole nation that was mourning the death of Princess Diana. This feeling of grief could be understood as existing in the crowd and having been taken in by individuals. Ahmed herself criticizes the 'outside in' model because it also, just as the 'inside out' model, considers emotions as something 'we have', and in the case of Diana's death, the crowd becomes the one who 'has feelings' (Ahmed 2004: 9-10). Taking this into consideration, Ahmed presents her sociality of emotion model in a way that rejects the idea that emotions are something ' $\mathrm{I}$ ' or 'we' have. 'Rather, it is through emotions ... that surfaces or boundaries are made: the "I" and the "we" are shaped by, and even take the shape of, contact with others' (Ahmed 2004: 10). Emotions, Ahmed suggests, circulate and move, but they also become attached. 'Movement may affect different others differently ... emotions may involve "being moved" for some precisely by fixing others as "having" certain characteristics' (Ahmed 2004: 11).

According to Ahmed, emotions can be studied through figures of speech that are necessary for the emotionality of the text (Ahmed 2004: 11-13). In order to 
analyse emotions in texts, she proposes focusing on figures of speech, such as metaphors. Ahmed views metaphors as a means of conveying emotions (ibid.). A metaphor is a manner of talking about an entity by experiencing and understanding it via something else (Lakoff \& Johnson 2003: 5).

Marander-Eklund utilizes Ahmed's method with a few additions in her article on memories from the 1950s Finland. While Ahmed suggests focusing on emotional words and metaphors, Marander-Eklund adds a third category to the emotion analysis - words with emotive character, or emotive expressions. This third category of emotional communication is necessary since emotions are not always clearly expressed through the process of naming them or through metaphor in her material on post-war memories. I have made the same observation regarding my web forum material. In order to analyse the material using the emotive expression, I focus on the use of emotionally charged words, whether the words are neutral or intense, positive or negative. For instance, words such as wonderful and brilliant are positive, while miserable and arrogant are negative - and all four of them are intense. Emotive expressions are expressive in character and the opposite of matter-of-fact statements (Marander-Eklund 2009: 25).

The named emotions, such as 'hate', rarely occur in my material, an aspect that I will discuss further in the analysis chapter. Ahmed argues that the naming of an emotion makes the emotion 'real', resulting in different kinds of actions and orientations (Ahmed 2004: 13). Metaphor and emotive expressions work in a similar fashion. Emotive expressions are words with emotive character, which are used to convince the reader or listener. An emotive expression can also be used to express a particular emotion or attitude and/or to provoke a particular emotion or attitude (Hedquist 1978: 1). An emotive expression does not name an emotion but may allude to the writer's own feelings about something or try to influence the intended recipient's feelings. As noted by Marander-Eklund, this is a wide definition that also encompasses the effect of emotive expressions on the reader or listener (Marander-Eklund 2009: 25). This, of course, includes me as a researcher and a Swedish-speaking Finn.

In Marander-Eklund's article from 2009, the material consists of answers to a questionnaire in which the respondents were specifically asked to write about life in Finland during the 1950s. My material for this article is palpably different, as it is created out of posts on a web forum that were not originally intended for research. The writers are also unaware of my presence as well as my intent. In Ahmed's (2004) material, on the other hand, I find that there are some similarities to mine. She analyses public material from websites hosted by the British National Front, a right-wing populist party, and the American white supremacist organization Aryan Nation. Whereas the content of Ahmed's 
material is similar to mine, the setting is different. My material originates from a more 'neutral' and diverse source, a debate forum that is open to various topics. Hence, I will examine whether Ahmed's and Marander-Eklund's methods and theories are applicable to web forum material.

\section{SWEDISH IN FINLAND}

Finland and Sweden share a common history, which is why Finland has a population of Swedish speakers. Finland was a part of Sweden for over 600 years, until 1809, when Finland became an autonomous part of the Russian Empire. Swedish and Russian ${ }^{4}$ served as official languages in Finland until 1863, when Finnish was made an official language, along with Swedish, by the tsar. To wean the Finns from their Swedish influences, the Russians encouraged them to develop cultural, political, and financial institutions and traditions of their own (Coleman 2010: 47). Consequently, the idea of an independent Finnish nation began to evolve. Language was an essential part of the nation-building process and both Finnish and Swedish speakers argued Finland should become monolingually Finnish in order to build a unified nation (Coleman 2010: 49). Swedish speaker Adolf Ivar Arwidsson is quoted as saying, 'Swedes we are no longer, Russians we cannot become; we must be Finns' (Coleman 2010: 49; McRae \& Helander \& Luoma 1997: 32). This served as a guiding principle of Finnish nationalism (ibid.).

From the 1840s, the Finnish national movement, the Fennoman movement, comprised of the political and cultural elite in Finland - both Finnish and Swedish speakers - worked to make Finnish a language of culture and science, arguing for the teaching of Finnish national history in schools, thus elevating the Finnish language from its former status as a language of the peasantry (Coleman 2010: 49). Although the Finnish peasantry itself hardly showed any interest in national or cultural matters, it was a movement driven by a very small elite (Honko 1980: 47-48). The Fennomans published much of their work in the Finnish language, spreading their ideas to both language groups. As a reaction to this, the Swedish national movement, the Svecoman movement, arose to uphold the elite position of the Swedish language (Coleman 2010: 49). The late nineteenth and beginning of the twentieth centuries were dominated by language disputes. In 1945, in concurrence with the end of the war with the Soviet Union, peace was made between the languages, much due to the radical changes in Finland's social and political situation (McRae \& Helander \& Luoma 1997: 80-81). 
Earlier, a large part of the upper classes had been dominated by Swedish speakers, but since the beginning of the twentieth century, this social divide has faded. However, one may describe Swedish speakers as a predominantly middle-class population (Allardt \& Starck 1981: 182). Nonetheless, the notion of the Swedish-speaking upper class persists both in the vernacular and popular culture. Swedish speakers are referred to as 'better people', upper-class, snobs, et cetera (Klinkmann 2014: 121-122; Heikkilä 2011).

Finland declared its independence in 1917. The Constitution of Finland, written in 1919, states that the nation has two languages, Finnish and Swedish. Today, Finland has a population of 5.5 million. Slightly over five percent of the population is registered as being Swedish-speaking (Statistics 2017a, 2017b). The teaching of Swedish is mandatory in Finnish-speaking schools and vice versa. The teaching of Swedish in Finnish-speaking schools, however, is continuously up for political debate. ${ }^{5}$ In its wake follows an often spiteful debate about the Swedish-speaking population and the Swedish language in Finland.

Hate speech directed at the Swedish-speaking population in Finland is not a new phenomenon, just as hate speech in general existed long before the Internet; see, for example, Bo Almqvist on insult poetry in the Nordic countries (1965), Lars M. Andersson on representations of 'the Jew' in Swedish comic press around 1900-1930 (2000) and Erik Falk's thesis Verbal Insults in Uppsala [Sweden] during the 1630s (2011). The difference, today, is the possibility to reach a much bigger audience than you might by scribbling on a wall or shouting in the streets.

In Finland, hate speech is not directed only toward the Swedish-speaking population. It also targets, for example, various ethnic groups (the Sami, Romani people, Russians, and Somalis, to mention a few), immigrants, asylum seekers, politicians, journalists, researchers, and women (Lähdesmäki \& Saresma 2014: 300-301; Pöyhtäri \& Haara \& Raittila 2013: 33-43). According to the survey report entitled 'I often find myself thinking how I should be or where I shouldn't go' - Survey on hate speech and harassment and their influence on different minority groups, published by the Finnish Ministry of Justice, Unit for Democracy, Language Affairs and Fundamental Rights in 2016, representatives of minority groups are more exposed to harassment and hate speech than those of the majority population. As noted by Tuuli Lähdesmäki and Tuija Saresma (2014), among others, there is a connection between the recent rise of populism and nationalism in Finnish politics and the increase of online hate speech. 


\section{WEB FORUM MATERIAL}

The material used in this article consists of quotes from the public web forum at Suomi24. The commercial website Suomi24. $\mathrm{f}^{6}$ is one of the largest social networking sites in Finland with 3.5 million visits per week, according to their own statistics from $2015^{7}$. Besides the discussion forum, the site provides, for example, a dating forum, an e-mail service and chat rooms. The discussion forum is divided into several groups with topics like hobbies, travelling, economy, sports, family, and society. These groups are then divided into subgroups like the society discussion group, from which most of my material originates, with subtopics like animal protection, conspiracy theories, the European Union, feminism, history, immigration, media, and politics. These subgroups are divided into even more specific subjects. For example, under politics, one can find topics such as government, parties, and the president, which are then further divided into smaller groups, and so on. On Suomi24, no registration is required and anyone can write a text and publish it as a new post, or write a comment to a post or another comment. Therefore, one main post may consist of several discussion threads.

The material presented in this article originates primarily from September 2015, when I searched for evident examples of online hate speech directed at the Swedish-speaking population in Finland. I started out searching for forum posts with the word 'hurri' (a common pejorative used for the Swedish speakers in Finland and for the Swedes in Sweden) through the site's own search engine. Other findings are the result of associations I made while browsing the listed forum threads. For example, words like 'sveco' (short for Svecoman, see section "Dehumanisation"), 'RKP' (Ruotsalainen kansanpuolue: The Swedish People's Party of Finland), names of Swedish-speaking politicians and other Swedish-speaking public figures made me examine the content of the discussions more closely.

The forum posts used in this article date back to April 2015. Most of the forum posts were published around the time when I did most of my searches, the 8 th of May 2015, and the 9th and 10th of September 2015. The exact dates are found together with the quotes in the analysis. I decided not to look for more material from a longer period of time for this article because I think this also shows that one does not have to dig very deep to find this particular kind of hate speech. My search for material in the web forum also came to a point where I noticed that the content of the posts started to repeat itself and I decided my material had reached saturation. The quotes presented in this article act as representatives of several other quotes on the same theme. Although my material consists of 14 separate main posts, the linked comments increased the 
total to 25 posts. The original quotes are in Finnish. ${ }^{8}$ According to Suomi24's own rules, the two official languages on the site are Finnish and Swedish, but most of the content on the site is in Finnish (Suomi24 2016). Most of the forum posts are still available online, but a handful of them have been deleted by the administrators without any further explanation.

I have not been in contact with the forum administrators or with the debaters. As mentioned before, the material is published in an open web forum accessible to anyone and requiring no registration. The participants in the debate forum change their signature depending on the discussion topic. In my material, all 25 posts have different signatures and they are not linked to any e-mail addresses or sites. I have, therefore, decided, after a brief discussion with the university research ethics committee, that informed consent is not needed (cf. Markham \& Buchanan 2012).

As stated above, the original quotes are in Finnish and the ones presented in this article are translated into English by an authorised translator. There is, of course, still a risk of misinterpretation and a loss of nuances. To weed out as many errors as possible, I have made an in-depth evaluation of both the original and the translation in my analysis.

\section{REAL FINNISH MEN AND DECEITFUL WOMEN}

My material contains the three categories presented by Ahmed (2004) and Marander-Eklund (2009): emotional words, metaphors, and emotive expressions. Just as Marander-Eklund notes in her article, the presence of actual emotional words is sparse. Out of my 25 quotes, I have found only a couple of examples of an emotion actually being named (see Post $1 \& 4$ ). On the other hand, the use of metaphor as well as emotive expressions is frequent. Concerning emotive expressions, I argue that the majority of my material might qualify as being emotive in the sense that the writer uses certain words to express and/or to provoke a certain emotion or attitude. Hence, I choose not to analyse the material solely based on this categorization. During my reading of the texts through emotive expression, emotional words, and metaphors, three themes surfaced: suspicion, demasculinization and dehumanization. In the following passage, I will present examples of all three different types and make a contextual and in-depth analysis of the textual content. 


\section{Suspicion}

Suspicion is based on sentiments and stereotypes; a suspicious person is not to be trusted. Casting suspicion upon a group can become an instrument for discrimination disguised as a self-protective strategy. For example, as Juliana Ochs shows in her ethnographical study of everyday life in Israel, Israelis use the term 'suspicious people' as a euphemism for Palestinian or 'Arab-looking' people. Naming them 'suspicious people' depicts their fear of Palestinians as a question of security rather than discrimination (Ochs 2011: 82).

Suspicion is used here as a category for material containing examples of hate speech that casts suspicion upon the Swedish-speaking population. The material shows expressions of general distrust towards the Swedish-speaking population in Finland, and it is conveyed by questioning whether the Swedishspeakers see themselves as a part of the Finnish population or as Swedes.

Insolence seems to be something that the Hurri-shitheads inherited from their Swedish ancestors. Here in Finland, you are the most hated group because of your arrogance towards the main population. Note that the main population comprises 95 percent of the people in Finland and you, a Swedish group of shits or Hurri-shitheads, are only a measly 5 percent. (Post 1)

The word Hurri requires further explanation, as it is used in the majority of the comments. There are several etymological theories regarding the origins of the word Hurri. According to language expert Mikael Reuter it has been a well-known pejorative for Swedish speakers in Finland at least since the beginning of the twentieth century. Reuter argues that mongers were called Hurri in several Finnish dialects and, furthermore, that the word has been used as a euphemism for 'wolf' (Reuter 1999). Today it is commonly used as a pejorative for the Swedish-speaking population as a whole. However, Hurri is not always understood in a negative sense in all contexts. It can also be used by the Swedish-speakers themselves, mostly as a form of self-irony (Klinkmann 2014: 125). In this particular context, however, I argue that it is used as a word of abuse. In this example, the negative connotation is accentuated by the addition of the word 'shitheads'. Furthermore, using words such as shithead or other terms alluding to faecal matter is common when talking about an opposing group (Lindqvist 2001: 206). A word such as Hurri cannot be detached from its history as a pejorative, despite its other usages and interpretations; in Ahmed's words, it tends to stick (Ahmed 2004: 59-60, 89ff.). In this article, Hurri is considered a negatively charged metaphor for the Swedish-speaking population in Finland. 
The word 'hated' in the quote above is one of the aforementioned rare examples of an emotional word found in my material. Marander-Eklund made a similar observation in her article on post-war memories (2009: 35-36). Her interpretation is that the informants wrote about things that happened decades ago and this may have led to some reconstructions of the memories. Regarding examples of online hate speech in the material used in this analysis, I argue that the writers are more likely to use emotive expressions and metaphors because obviously emotional arguments are not accepted as easily as stated 'facts'. However, the writers cannot fully conceal their emotions and attitudes, thus resulting in more or less emotional statements (cf. Mral 2013: 107; Walton 1992).

Looking at Post 1 as a whole, one notices that the writer is excluding the 'you', the Swedish speakers, from 'the main population' by using the pejoratives Hurri and 'shithead', and is stating that the Swedish speakers are descendants of Swedes and, therefore, inherently arrogant. In naming an emotion, such as hate, Ahmed argues that a feeling does exist before the utterance, but the effect of naming it makes it 'real' and, as a result, it shapes 'different kinds of actions and orientations' (Ahmed 2004: 13). The implied 'we' in this quote distances itself from the arrogant Swedish-speaking shitheads. By mentioning the main population's large numerous advantage, I also sense an underlying threat. The Swedish speakers are made aware of their disadvantage in relation to the Finnish speakers.

The quote highlights the notion of Swedish speakers as arrogant, a group who sees themselves as better than the Finnish speakers. By juxtaposing the 'main population' and the 'Swedish group', the writer emphasizes the Swedish speakers' position as outsiders. In addition, the word Swedish (ruotsalainen in the original quote) is used instead of a Swedish-speaking Finn (suomenruotsalainen in the original quote) to further stress that the group in question is not Finnish.

The claim that the Swedish speakers are the most hated group in Finland is a very strong statement. The statement also raises the question of which other groups are hated, although not as much as the Swedish speakers. Arrogance toward the Finnish speakers is stated as the reason for this hate, which makes me question whether being arrogant really is this despicable, or does this socalled arrogance imply something else? What does it mean to be arrogant? The Oxford English Dictionary explains arrogance as follows:

The taking of too much upon oneself as one's right; the assertion of unwarrantable claims in respect of one's own importance; undue assumption of dignity, authority, or knowledge; aggressive conceit, presumption, or haughtiness. (OED 2016a) 
Considering this definition in this particular context, the Swedish speakers' arrogance could imply that they see themselves as superior to the Finnish speakers and, therefore, act badly towards them (cf. Saukkonen 2011: 92-93). The notion of the Swedish speakers' arrogance dates back to the nineteenth century, when Swedish was the only official language in Finland. Marja Vuorinen has pointed out that the Swedish nobleman was made to represent the enemy from the old empire by the Fennoman movement in the nineteenth century. The Finnish-speaking intelligentsia viewed the nobility as remnants of the Swedish rule and, therefore, something the people must distance themselves from in order to build a democratic nation (Vuorinen 2005: 249-250). Johan Wilhelm Snellman (1806-1881) formulated the ideas of the Fennoman movement. Language was a central part of Snellman's thesis on how to develop the country, and he saw the language as a reflection of the nation's own unique way of thinking. Therefore, he felt that Finland should become monolingually Finnish (Lindgren, A. \& Lindgren, K. \& Saari 2011: 21). Anna-Riitta Lindgren, Klaus Lindgren, and Mirja Saari describe the 1800s as 'the century of assimilation politics', an era when nationalism with its ideas of monolingual nation states spread through Europe (Lindgren, A. \& Lindgren, K. \& Saari 2011: 24).

According to Vuorinen, the hatred toward the Swedish-speaking population in Finland was linked to the hatred toward the upper classes. The fact that there were Swedish speakers among the common people was ignored by the Fennomans. Rather, the Finnish nationalists willingly quoted the racial theories emerging in Sweden, according to which Swedes were large, lively and hard-working Germans, while the Finns were melancholic, untalented and slow descendants of Siberian Ugric tribes, unable to build a nation of their own. These views strengthened the idea of the Swedish speakers as being hateful and considering themselves to be superior to the Finnish speakers (Vuorinen 2005: 259-260). By labelling somebody as hateful, they become objects of hate, which in turn corroborates our impression of them as hateful (Ahmed 2004: 52). By labelling Swedish speakers as arrogant, the hatred toward them is vindicated, because they are hateful.

The suspicion of Swedish speakers as a group is shown through questions inquiring whether they want to be a part of the Finnish nation or not.

Hurri Fantasy number 1. Why do some Hurris want Finland to come under Sweden's rule again? (Post 2)

Hideous traitors to the country. (Post 2.2)

Row back to Sweden, Hurris, just like you fled during the war. (Post 3) ${ }^{9}$ 
Post 2 claims the Hurris are fantasizing about Finland coming 'under Sweden's rule again'. By not writing, for instance, 'become a part of Sweden again', which is a common view on the shared history of the two nations (cf. Klinge 2000 [1981]; McRae \& Helander \& Luoma 1997: 26-27), the quote is connected to the occupation discourse, according to which Finland was occupied by Sweden but not an equally integrated part of the kingdom ${ }^{10}$ (Vilkko 2014: 225-228). Post 2.2 answers the question posed in Post 2: Swedish speakers 'want Finland to come under Sweden's rule again' because they are 'hideous traitors to the country'. Post 3 expresses the same view on the Swedish speakers as traitors not to be trusted, by suggesting they 'row back' to Sweden like they 'fled during the war'.

'Row back' is a thought-provoking metaphor considering it is actually possible to row a boat from Finland to Sweden over the Gulf of Bothnia. Furthermore, the sea has been, and still is, important for the communication between the two countries. Today, during the ongoing migrant crisis, people are migrating to Europe by boat, ${ }^{11}$ and we are exposed to pictures of these migrants almost daily. Post 3 was published at the time when the amount of asylum seekers started to increase noticeably in Finland. ${ }^{12}$ The discourse about fleeing the war and consequently your duty to fight for your country is similar to the ones expressed in the posts quoted above. While Syrian men are accused of fleeing instead of fighting, ${ }^{13}$ the Swedish speakers in Finland are blamed for not having fought for Finland during the wars in 1939-1945. ${ }^{14}$ However, it is an incorrect statement to claim that the Swedish speakers in Finland fled the war; there were, for example, several monolingually Swedish infantry regiments (Juutilainen 1997). A film based on the experiences of the Swedish-speaking soldiers in the 61st Infantry Regiment, entitled Beyond the Front Line, reached large audiences nationally (Strandén 2010: 127). Therefore, I argue that the claim is a metaphor for the Swedish-speaking population's untrustworthiness; the Swedish speakers cannot be trusted as citizens of Finland.

Suspicion is expressed in these quotes through metaphors that imply that Swedish speakers are spineless quislings. Emotive expressions are used to illustrate both the writer's own views and to convince the other debaters of the Swedish-speaking population's untrustworthiness.

\section{Demasculinisation}

Demasculinization is, in this work, perceived as a strategy to strip the Swedishspeaking men of their gender-related authority (cf. Ferber 2000: 45-48). I argue that this authority and male privilege is connected to the notion of hegemonic masculinity, where certain masculinities are more dominant and encouraged 
than others in society. Hegemonic masculinity is not necessarily the most common pattern of masculinity in a society, but is produced through certain exemplars of masculinity, such as professional athletes, symbols of authority, even though most men and boys do not manage to completely live up to them (Connell $\&$ Messerschmidt 2005: 846). In this section, I will analyse a quote in which Swedish-speaking men, in both Finland and Sweden, are considered unmanly since they are not characterised by the hegemonic masculinity represented by the Finnish-speaking men in Finland.

Oh my, the Hurri 'men' are jealous of us 'Fennos', us real Finns, we who are real men and not slick, gay-looking clowns - like the Håkans. Hurri 'men' are like Swedish men, feminist wimps who are being laughed at. (Post 4)

The author of Post 4 prides himself on being a 'real man' and a 'real Finn' and hence, a part of the hegemonic masculinity, while the Swedish-speaking men in Finland are not fulfilling the demands of the hegemony.

The word 'men', with quotation marks added to emphasise the ironic tone, is being used as a metaphor for men who do not fulfil the demands of hegemonic masculinity. '[M]en' are the opposite of real men. 'Fennos' is a metaphor, which is clarified in the quote as meaning real Finns, real men, and the definition of a real Finn and a real man is explained through the contrast between 'the Hurri "men" and 'Swedish men'. While the quotation marks are added around the word 'men' for ironic emphasis, 'Fennos' should be read as so-called Fennos, the quotation marks indicating the writer might not be sure if the use of the word is entirely correct in this context. ${ }^{15}$ The quote states the "men" are 'jealous' of the 'real men'. Jealous is an emotional word that implies that Swedish-speaking men are envious of Finnish-speaking men because of their so-called real manliness. The idea of an allegedly real or true Finnish masculinity is analysed by folklorist Mikael Sarelin in his dissertation on constructions of masculinities within Finnish Black Metal music. According to Sarelin, the real Finnish man is the opposite of the so-called metrosexual man, a man who cares about his looks and soft values, someone who might be considered as having feminine qualities (Sarelin 2012: 162-164). Feminine characteristics are associated with homosexual men who are subordinate to the hegemonic masculinity - hence the Hurri men and Swedish men are inferior to the 'real men' in Finland (Connell \& Messerschmidt 2005: 837). Lars M. Andersson uses the national body as a term for the ideal masculinity presented by the Swedish men (in Sweden) in contrast to the Jewish man's unmanly body. Andersson argues that the ideas of masculinity and nationality overlap to a great extent (Andersson 2000: 120-126). The similarities in terms of how the Swedish-speaking men are depicted are striking; Swedish-speaking men are unmanly 'slick gay-looking clowns', Jewish 
men are pictured as cuckolds, physically weak and, therefore, unfit as soldiers and possibly homosexual (ibid.). 'Looking gay' is not accepted by the hegemonic masculinity and being a clown is being laughed at. The clown is a metaphor for someone being ludicrous, laughable, and not to be taken seriously. Clown, pelle in the original quote, also translates into fool or buffoon in Finnish, which may be linked to the idea of the emasculated Swedish-speaking man (Lindqvist 2001: 218-220).

'The Håkans' (håkanit in the original quote) is synonymous with using homo as a pejorative (Lindqvist 2001: 218-219). Håkan is a common Swedish male name and contains the letter 'å' (capital ' $\AA$ '), which is not commonly used in the Finnish language. " $\AA$ " is a letter in the Swedish alphabet and in Finnish it is only used in names or words of Swedish or foreign origin (Häkkinen 2005: 83). As noted by Yrsa Lindqvist, it is common to label an opposing group as being deviant. In this case, Finnish speakers have labelled (male) Swedish speakers as homosexuals. Homosexuality is, here, perceived as something unnatural, unwanted, and foreign to Finnish norms. The link between Swedish and something refined and upper class and, even further, as something feminine and effeminate, creates the notion that Swedish is the opposite of what a Finnish man is supposed to be (Sarelin 2012: 162-164; Lindqvist 2001: 218-220).

The post also refers to Swedish-speaking men as 'feminist wimps'. My interpretation of this statement is that it refers to the Swedish public discourse on feminism; Sweden is known for equality in its politics. For instance, in 2015, the Swedish government declared itself the first feminist government in the world (Government Offices 2015). Consequently, Post 4 could be read as a characterisation of the Swedish men as demasculinised - they have let the women strip them of their power by becoming feminist. As noted by Abby L. Ferber, among others, the women's movement is blamed for corrupting the natural gender order, which has led to the demasculinisation of men (Ferber 2000: 46). The Swedish-speaking men in Finland are placed in the same category as the Swedish men and, therefore, the Swedish-speaking men are just as laughable and sissy. By contrasting them to the Finnish speakers, the latter become a part of the hegemonic masculinity and the Swedish speakers are left out.

\section{Dehumanisation}

To dehumanise someone is to deprive them of human character or tributes (OED 2016b). Dehumanisation is a tool for discrimination and a pejorative term. Karen Stollznow compares dehumanisation to demonisation; both have been used by regimes, movements, and individuals to characterise an object 
as 'bad' or 'inferior' and, consequently, undeserving of equal rights (Stollznow 2008: 177-178). In the following quote, demonisation might have been just as suitable as dehumanisation; however, I find that the term dehumanisation encompasses a wider range of my material.

[Her] nickname is 'smiling death'. She talks with a soft voice and conducts herself calmly, but inside she is a fanatic Sveco-bitch. A truly RANCID Svecosuru. $\left(\right.$ Post 5) ${ }^{16}$

During my search for examples of hate speech on Suomi24, I discovered a word previously unknown to me in this particular context, namely suru. In Post 5, it is written together with sveco (short for Svecoman, more on this further down in this section). After some online research, I found that suru is short for suomenruotsalainen, which translates into Swedish-speaking Finn, and is, seemingly, mostly used in debate forums. Suru is shorter than suomenruotsalainen, hence more convenient, but suru is also the word for grief or sorrow in Finnish. Considering this and the context where it is used, I argue that it can be understood as a pejorative in the same sense as Hurri.

'Smiling death' gives frightening and negative associations. Death is a metaphor for darkness and the end of life, add a smile to that and it becomes even scarier - death in the shape of a grinning mask. What 'smiling death' denotes, is the death trying to disguise itself, making itself seem harmless - or is it a mocking smile? After reading the rest of Post 5, I interpret 'smiling death' as a metaphor for being Janus-faced, i.e., nice and calm on the outside, but deceitful inside. After some further research, I found a new forum post from 31 March 2016 with content similar to Post 5. It explains that this female politician is called 'smiling death' because she is a soft-spoken person with small gestures but an extremely fanatic Svecosuru (Post 6). There are records of both Finnish speakers and Swedish speakers comparing each other to the devil, which may be interpreted as associating the unknown, something not like us, with evil (Lindqvist 2001: 210-211). Naming someone 'smiling death' and Svecosuru are examples of dehumanisation; it deprives the person of her humanity.

Stating that in reality, 'inside', she is a 'fanatic Sveco-bitch' can be understood as her hiding the fact that she is an extreme Swedish nationalist - a Svecoman. The Swedish national movement arose in the mid-1800s as a reaction to the Finnish national movement, the Fennomans. The Swedish speakers turned to the teachings of Axel Olof Freudenthal, who opposed Snellman's ideas to make Finland monolingually Finnish (Högnäs 1995: 52-54). Freudenthal was highly regarded by the Svecomans, as were his views on the Swedish speakers in Finland as guardians of the west against the barbarians in the east. As noted by Vuorinen, this highly resembles the Finnish speakers' attitude towards the Russians (Vuorinen 2005: 259-260). 
As a 'truly RANCID Svecosuru', she is so extremely nationalist it reeks. Through the use of strong adjectives such as fanatic and rancid, the commenters' hatred toward her is strengthened. The composition of sveco and suru further amplifies the emotionality of the post, depicting a person who is not just a Swedish speaker but a nationalist fighting for the rights of the Swedishspeaking population, in an aggressive but furtive manner. She is, therefore, not to be trusted since she hides her true intentions.

'Sveco-bitch' is a metaphor used to convince the reader that she actually is like a Sveco-bitch (cf. Saarikoski 2001: 130). Bitch, narttu in the original quote in Finnish, a word I argue is closer to its original meaning, female dog ${ }^{17}$, than the word bitch ${ }^{18}$ in English. The word bitch (in English) is also used in Finnish. The Finnish online urban dictionary also makes a distinction between narttu and bitch, narttu being a very crude nickname for a woman and also meaning female dog, while a bitch is an argumentative, stubborn, and sometimes slutty woman. Furthermore, bitch is a word used by women as a pejorative for other women (US a, US b). Therefore, I argue that the word narttu (translated to bitch in Post 5) is an example of dehumanisation, an even stronger example than bitch. Naming someone a narttu or a bitch is depriving her of her human traits and labelling her an animal with strong sexual implications. Closely associated to bitch, whore is a metaphor for a woman who is not a proper or real woman - she is like a whore (Falk 2011: 193-194; Saarikoski 2001: 131). Stating she is a bitch emphasises her being female and, even more so, a lewd woman. A man naming a woman a bitch is a show of power, because there is no equivalent pejorative for men (Saarikoski 2001: 87). According to Lindqvist, a common trait in narratives about an opposing group is an allusion to sexuality, or a comparison to animals or excrement (Lindqvist 2001: 206). Bitch encompasses both sexuality and a comparison to animals.

The female politician referred to in the quote above is a woman with political power; she is a part of the Swedish-speaking population and a well-known public figure. Calling her a bitch because she is a woman is exercising oppression. In Post 5, she is made to represent the Swedish-speaking population as a whole and is, therefore, seen as a threat to be warded off. A bitch may bark but will never be accepted by the male hegemony.

Another example of how dehumanisation is used as a strategy by the hatemongers is the following post in answer to Post 2, which asks why the Swedish speakers 'want Finland to come under Sweden's rule'.

Because they are pigs. (Post 2.1)

The Swedish speakers are named pigs. Pig is a metaphor for a dirty animal but also someone who is greedy and lazy. If you eat like a pig, you have bad table manners; a capitalist pig exploits others and only cares about making more 
money; if you are pig-headed you are stubborn and refuse to listen to anyone else. All of the above are found in the discourse about the Swedish-speaking population, for example, in terms of the upper classes exploiting the common people and the ongoing debate about the mandatory teaching of Swedish in Finnish-speaking schools (Vuorinen 2005: 249, note 5).

With emotional words, metaphors, and emotive expressions as a point of departure, I have made a contextual and intersectional analysis with a focus on class, gender, and ethnicity. As traitors to the country, the Swedish speakers attract an extra strong hatred because they are "not a distant "other" but the enemy within' (Thiranagama \& Kelly 2012 [2010]: 2). The Swedish speakers are a group of which to be suspicious. By accusing Swedish speakers of treason, the hatemongers take it upon themselves to decide who is a part of the nation and who stands outside.

This suspicion is, furthermore, linked to the violation of norms made by the Swedish-speaking men because they do not fulfil the demands of the Finnish hegemonic masculinity and they are, therefore, depicted as demasculinised. As demasculinised men, they are nothing but a bunch of sissy wimps who no longer pose a real threat to the Finnish men, while the Swedish-speaking women are presented as a huge risk to the nation as fanatic Swedish nationalists hiding in plain sight. By dehumanising Swedish speakers, the commenters make them appear inferior and not worthy of being treated as equals to the Finnish speakers.

\section{CHARGED STATEMENTS}

The aim of this article was to study how emotions are performed in online hate speech directed at the Swedish-speaking population in Finland through the analysis of web forum posts and by using Ahmed's method with MaranderEklund's addition to the method. I have done this by focusing on emotional words, metaphors, and emotive expressions.

By analysing the selected posts, I find that emotive expressions and metaphors are used to strengthen the negative statements made about the Swedishspeaking population. As stated by Douglas Walton, '[a] weak or irrelevant argument can be taken as strong and relevant because of its powerful emotional impact on the respondent' (Walton 1992: 2), while naming emotions such as hate personalises the argument and makes it less credible and more about the arguer him- or herself (Walton 1992: 219-220). Therefore, I found that MaranderEklund's addition to Ahmed's method, the use of emotive expressions as a third category for analysing emotions in texts, was of great importance in analysing my material. Moreover, I argue that emotive expressions often include whole 
sentences or passages that together create an emotionally charged statement, while on their own, they may seem neutral.

After analysing the material, my conclusion is that the online hate speech results in and works through othering (cf. Ahmed 2004: 1-2; Sjö \& Häger 2015: 27-28). It creates an 'us' in relation to 'them'. In Ahmed's words, the expressed emotions create surfaces or boundaries between 'us' and 'them'. Emotions both circulate and stick; some people may be moved by emotion while others are branded by them (Ahmed 2004: 10-11). 'The others' are made into the enemy by describing them as arrogant and traitors to the country, and by depicting them as deviant and depriving them of their human traits. In Ahmed's words 'those who are "not us", and who in not being us, endanger what is ours' (Ahmed 2004: 1). The Swedish speakers are portrayed as a group not to be trusted and, therefore, words such as traitor, pig, and gay-looking clown are assigned to the Swedish speakers with all their implications.

\section{ACKNOWLEDGEMENTS}

This work was supported by the Committee for Ethnology and Folkloristics at the Society of Swedish Literature in Finland.

\section{NOTES}

1 The Sámi, Roma people, foreign-language speakers, foreign nationals and immigrants, disabled people, and members of religious, gender, and sexual minorities (MoJ 2016). A report on the Swedish speakers' experiences will be published later, according to the Ministry.

2 Breivik was convicted for mass murder and terrorism in Norway. On 22 July 2011, he killed eight people by detonating a bomb in the government quarter in Oslo, and then shot and killed 69 people on the island of Utøya (Townsend 2012).

3 This article is to be read as a part of my dissertation process. The working title of my thesis is Hate speech online: A folkloristic study of Internet hostility toward the Swedish-speaking population in Finland. The aim of my thesis is to study how online hate speech toward the Swedish-speaking population in Finland is made performatively. I will do this by focusing on three themes: 1) Hate speech online - when and where does it occur and how is it expressed? How is hate manifested in relation to class, ethnicity, and sex? 2) Experiences of hate speech online - how do those affected relate their experiences? 3) How do the media describe the online hate speech and the hatemongers?

4 In the late 1800 s and early 1900 s several Russification campaigns aimed to increase the use of the Russian language in Finnish government and administration and make 
the study of the Russian language and literature compulsory in Finnish schools. The Russian authorities failed to fully implement their plans. By the end of the Russian rule, merely 0.2 percent of the Finnish population was Russian-speaking (Coleman 2010: 47-48).

5 During the process of writing this article, a second citizens' initiative against the mandatory teaching of Swedish in Finnish schools was announced by the Language Choice Society (Vapaa kielivalinta ry). The initiative did not reach even half of the required 50,000 signatures within six months, and could not be submitted to the Parliament for consideration (see Initiative a, b). A previous initiative was rejected by the Parliament in March 2015 (Riksdagen 2015).

6 The site is owned by Aller Media.

7 See https://www.aller.fi/wp-content/uploads/2016/01/Suomi24-Tuotekortti-1_2016.pdf, last accessed on 19 October 2018.

8 My material is archived in the Cultura Archives at Åbo Akademi University.

9 Post 3 has been removed from the forum without any explanation as to why it was done, while posts 2 and 2.2 were still online in December 2015. Post 2.2 is posted as a comment to Post 2, while Post 3 is a separate post on the same theme.

${ }^{10}$ Sweden's part in Finnish history was debated in 2013, when the Finnish public service company Yle broadcasted the television series Suomi on ruotsalainen (Finland is Swedish). The critique was extremely aggressive and the presenter Juhani Seppänen was threatened and called a traitor to the country (Björkqvist 2013).

11 The International Organization for Migration estimates that over a million migrants arrived by sea in 2015 (IOM 2015).

12 The Ministry of the Interior published a press release on 4 September 2015 estimating that 25,000-30,000 asylum seekers would arrive in Finland by the end of the year (MoI 2015). In 2014, a total of 3,615 people sought asylum in Finland (FIS 2015).

${ }^{13}$ I do not suggest there are any further similarities between the current war in Syria and the war in Finland.

${ }^{14}$ Finland fought three wars during the Second World War: The Winter War of 19391940, the Continuation War of 1941-1944 against the Soviet Union, and the Lapland War in 1944-1945 against Germany (Lavery 2006). I assume this is 'the war' implied in Post 3 , since these are the only wars fought during Finland's independence except for the Civil War in 1918.

${ }^{15}$ Fenno is short for Fennoman, member of the Finnish nationalist movement. See Swedish in Finland.

${ }^{16}$ I have removed the name of a Swedish-speaking politician in this post. Post 5 has been removed from the forum by the administrators without any further explanation.

${ }^{17}$ Dog can also be used as a derogatory term.

${ }^{18}$ See Kleinman \& Ezzel \& Frost 2009 for an in-depth analysis of the word 'bitch' and how it has become trivialized. 


\section{ARCHIVAL SOURCES}

Cultura Archives. Åbo Akademi University, Åbo, Finland (http://web.abo.fi/arkiv/ cultura/):

Post 1: IF 2016/001, 4

Post 2: IF 2016/001, 21

Post 2.1: IF 2016/001, 23

Post 2.2: IF 2016/001, 24

Post 3: IF 2016/001, 7

Post 4: IF 2016/001, 5

Post 5: IF 2016/001, 18

Post 6: IF 2016/001, 26

\section{REFERENCES}

Ahmed, Sara 2004. The Cultural Politics of Emotion. Edinburgh: Edinburgh University Press.

Allardt, Erik \& Starck, Christian 1981. Språkgränser och samhällsstruktur: Finlandssvenskarna $i$ ett jämförande perspektiv. [Language Boundaries and Social Structure: The Finns in a Comparative Perspective.] Stockholm: Almqvist \& Wiksell Förlag.

Almqvist, Bo 1965. Norrön niddiktning : traditionshistoriska studier $i$ versmagi. Volume 1. Nid mot furstar. [Old Norse Nið Poetry: Studies in the Tradition of Verse Magic. 1. Niðð Directed against Princes.] Stockholm: Almqvist \& Wiksell.

Andersson, Lars M. 2000. En jude är en jude är en jude... representationer av "juden" $i$ svensk skämtpress omkring 1900-1930. [A Jew is a Jew is a Jew... Representations of "the Jew" in Swedish Comic Press around 1900-1930.] Lund: Nordic Academic Press.

Björkqvist, Jeanette 2013. Sveriges påverkan i Finland en känslig fråga. [Sweden's Influence in Finland Is a Delicate Question.] Svenska Dagbladet, 9 February. Available at http://www.svd.se/sveriges-paverkan-i-finland-en-kanslig-fraga, last accessed on 27 September 2018.

Bjurwald, Lisa 2013. Skrivbordskrigarna: Hur extrema krafter utnyttjar internet. [Keyboard Warriors: How Extremist Forces Use the Internet.] Stockholm: Natur \& Kultur.

Blank, Trevor J. 2009. Folklore and the Internet: Vernacular Expression in a Digital World. All USU Press Publications, Book 35. Logan: Utah State University Press. Available at http://digitalcommons.usu.edu/usupress_pubs/35, last accessed on 27 September 2018.

Butler, Judith 1993. Bodies That Matter: On the Discursive Limits of 'Sex'. New York \& London: Routledge.

Coleman, Michael C. 2010. "You Might All Be Speaking Swedish Today": Language Change in 19th-Century Finland and Ireland. Scandinavian Journal of History, Vol. 35, No. 1, pp. 44-64. http://dx.doi.org/10.1080/03468750903315215. 
Connell, Raewyn W. \& Messerschmidt, James W. 2005. Hegemonic Masculinity: Rethinking the Concept. Gender \& Society, Vol. 19, No. 6, pp. 829-859. https:// doi.org/10.1177\%2F0891243205278639.

Council of Europe 1997 = Recommendation No. R97(20) of the Committee of Ministers to Member States on 'Hate Speech'. Council of Europe, Committee of Ministers. Available at https://rm.coe.int/CoERMPublicCommonSearchServices/DisplayDCT MContent?documentId=0900001680505d5b, last accessed on 26 September 2018.

Falk, Erik 2011. Verbala förolämpningar i 1630-talets Uppsala: En historisk talaktsanalys. [Verbal Insults in Uppsala during the 1630s: A Historical Speech Act Analysis.] Uppsala: Skrifter utgivna av Institutionen för nordiska språk vid Uppsala universitet. Available at https://uu.diva-portal.org/smash/get/diva2:433855/ FULLTEXT01.pdf, last accessed on 27 September 2018.

Ferber, Abby L. 2000. Racial Warriors and Weekend Warriors: The Construction of Masculinity in Mythopoetic and White Supremacist Discourse. Men and Masculinities, Vol. 3, No. 1, pp. 30-56. http://dx.doi.org/10.1177/1097184X00003001002.

FIS $2015=$ Finnish Immigration Service. Turvapaikanhakijat 1.1.-31.12.2014. [Asylum Seekers 1.1.-31.12.2014.] Available at https://migri.fi/ documents/5202425/6161882/50498_Tp-hakijat_tammi_2014.pdf, last accessed on 27 September 2018.

Government Offices 2015 = A Feminist Government. Government Offices of Sweden. Available at http://www.government.se/government-policy/a-feministgovernment/, last accessed on 27 September 2018.

Häkkinen, Kaisa 2005. Finska. [Finnish.] In: Iben Stampe Sletten (ed.) Nordens språk med rötter och fötter. Copenhagen: Nordiska ministerrådet, pp. 75-95. Available at http://norden.diva-portal.org/smash/get/diva2:700937/FULLTEXT01.pdf, last accessed on 19 October 2018.

Hedquist, Rolf 1978. Emotivt språk: En studie i dagstidningars ledare. [Emotive Language: A Study of Newspaper Editorials.] Umeå: Umeå universitetsbibliotek.

Heikkilä, Riie 2011. Bättre folk, bättre smak? Suomenruotsalaisten maku ja kulttuuripääoma. [Better People, Better Taste? The Taste and Cultural Capital of the Swedish-Speaking Finns.] Helsinki: Unigrafia. Available at https://core. ac.uk/download/pdf/14920889.pdf, last accessed on 27 September 2018.

Högnäs, Sten 1995. Kustens och skogarnas folk: Om synen på svenskt och finskt lynne. [People of the Coast and Forests: The View on Swedish and Finnish Temperament.] Stockholm: Atlantis.

Honko, Lauri 1980. Upptäckten av folkdiktning och nationell identitet i Finland. [The Discovery of Folk Poetry and National Identity in Finland.] In: Lauri Honko (ed.) Folklore och nationsbyggande i Norden. Åbo: Nordiska institutet för folkdiktning, pp. 33-51.

Initiative $\mathrm{a}=$ Monikielinen Suomi - ruotsi valinnaiseksi. [Multilingual Finland - Optional Swedish.] Citizens' Initiatives in Finland, 4 April 2016. Available at https://www. kansalaisaloite.fi/fi/aloite/1939, last accessed 31 October 2018.

Initiative $\mathrm{b}=$ Citizens' Initiatives in Finland. Ministry of Justice, Finland. Available at https://www.kansalaisaloite.fi/sv/anvisningar/briefly_in_english, last accessed on 28 September 2018. 
IOM 2015 = International Organization for Migration. EU Migrant, Refugee Arrivals by Land and Sea Approach One Million in 2015. 18 December. Available at https://www.iom.int/news/eu-migrant-refugee-arrivals-land-and-sea-approachone-million-2015, last accessed on 27 September 2018.

Jungar, Ann-Cathrine \& Jupskås, Anders Ravik 2014. Populist Radical Right Parties in the Nordic Region: A New and Distinct Party Family? Scandinavian Political Studies, Vol. 37, No. 3, pp. 215-238. http://dx.doi.org/10.1111/1467-9477.12024.

Juutilainen, Antti 1997. Rinta rinnan: Suomenruotsalaisten joukkojen sotatiet 19391944. [Side by Side: The War Routes of the Finnish-Swedish Forces 1939-1944.] Porvoo \& Helsinki \& Juva: WSOY.

Kleinman, Sherryl \& Ezzell, Matthew B. \& Frost, Corey A. 2009. Reclaiming Critical Analysis: The Social Harms of "Bitch". Sociological Analysis, Vol. 3, No. 1, pp. 4768. Available at http://www.uet.edu.al/images/Revistat_shkencore/sociolagical/ socio3_1.pdf, last accessed on 19 October 2018.

Klinge, Matti 2000 [1981]. A Brief History of Finland. Transl. by David Mitchell and Timothy Binham. Helsinki: Otava.

Klinkmann, Sven-Erik 2014. Finlandssvenskarna och humorns gränser. [The SwedishSpeaking Finns and the Limits of Humour.] In: Lars-Eric Jönsson \& Fredrik Nilsson (eds.) Skratt som fastnar: Kulturella perspektiv på skratt och humor. Lund: Lunds Universitet, pp. 117-138. Available at http://portal.research.lu.se/ ws/files/5296797/4857084.pdf, last accessed on 27 September 2018.

Lähdesmäki, Tuuli \& Saresma, Tuija 2014. Reframing Gender Equality in Finnish Online Discussion on Immigration: Populist Articulations of Religious Minorities and Marginalized Sexualities. NORA - Nordic Journal of Feminist and Gender Research, Vol. 22, No. 4, pp. 299-313. Available at http://dx.doi.org/10.1080/080 38740.2014.953580, last accessed on 19 October 2018.

Lakoff, George \& Johnson, Mark 2003. Metaphors We Live by. Chicago \& London: University of Chicago Press.

Lavery, Jason E. 2006. The History of Finland. Westport, CT \& London: Greenwood Press. Lindgren, Anna-Riitta \& Lindgren, Klaus \& Saari, Mirja 2011. From Swedish to Finnish in the 19th Century: A Historical Case of Emancipatory Language Shift. International Journal of the Sociology of Language, Vol. 2011, No. 209, pp. 17-34. http://dx.doi.org/10.1515/ijsl.2011.019.

Lindqvist, Yrsa 2001. "Natur och kultur" - stereotypernas uttryck. ["Nature and Culture"The Expressions of Stereotypes.] In: Anna-Maria Åström \& Bo Lönnqvist \& Yrsa Lindqvist (eds.) Gränsfolkets barn: Finlandssvensk marginalitet och självhävdelse $i$ kulturanalytiskt perspektiv. Helsingfors: Svenska litteratursällskapet i Finland, pp. 206-220.

Marander-Eklund, Lena 2009. "Kanske den bästa tiden i mitt liv": Analys av emotioner i ett frågelistmaterial om livet i efterkrigstidens Finland. ["Probably the Best Time of My Life": Emotion Analysis of Questionnaire Answers About Life in PostWar Finland.] Tidskrift for kulturforskning, Vol. 8, No. 4, pp. 22-38. Available at http://ojs.novus.no/index.php/TFK/article/viewFile/449/445, last accessed on 19 October 2018. 
Markham, Annette \& Buchanan, Elizabeth 2012. Ethical Decision-Making and Internet Research: Recommendations from the AoIR Ethics Working Committee (Version 2.0). Available at http://aoir.org/reports/ethics2.pdf, last accessed on 19 October 2018.

McRae, Kenneth Douglas \& Helander, Mika \& Luoma, Sari 1997. Conflict and Compromise in Multilingual Societies: Finland. Vol. 3. Waterloo, Ont.: Wilfrid Laurier University Press.

MoI 2015 = Inrikesministern samlade en grupp för att leda asylsituationen. [Minister of the Interior Gathered a Group to Lead the Asylum Situation.] Ministry of the Interior, Finland, 4 September. Available at https://intermin.fi/sv/artikkeli/-/asset_publisher/sisaministeri-kokosi-ryhman-johtamaan-turvapaikkatilannetta, last accessed on 24 October 2018.

MoJ 2016 = Ministry of Justice, Unit for Democracy, Language Affairs and Fundamental Rights. 'I often find myself thinking how I should be or where I shouldn't go': Survey on Hate Speech and Harassment and Their Influence on Different Minority Groups. Ministry of Justice, Finland, Publications 7/2016. Available at http://justitieministeriet.fi/sv/index/julkaisut/julkaisuarkisto/1456826655763/ Files/OMSO_7_2016_VIPU-raportti_158_s.pdf, last accessed on 19 October 2018.

Mral, Brigitte 2013. Attityder som retoriska medel: Exemplet kärnavfallsfrågan. [Attitudes as Rhetorical Means: The Example of Nuclear Waste.] In: Brigitte Mral \& Orla Vigsø (eds.) Krisretorik - Retoriska aspekter på kriskommunikation. Åstorp: Retorikförlaget, pp. 105-123. Available at https://www.researchgate.net/ publication/282703745_Krisretorik_Retoriska_aspekter_pa_kriskommunikation, last accessed on 28 September 2018.

Nussbaum, Martha C. 2013. Political Emotions: Why Love Matters for Justice. Cambridge, MA: The Belknap Press of Harvard University Press.

Ochs, Juliana 2011. Security and Suspicion: An Ethnography of Everyday Life in Israel. Series: Ethnography of Political Violence. Philadelphia: University of Pennsylvania Press.

OED 2016a = Arrogance. Oxford English Dictionary. Available at http://www.oed.com/ view/Entry/11054?redirectedFrom=arrogance\#eid, last accessed on 27 September 2018.

OED 2016b = Dehumanize. Oxford English Dictionary. Available at http://www.oed.com/ view/Entry/49153?redirectedFrom=dehumanization\#eid7229816, last accessed on 27 September 2018.

Pitkänen, Ville \& Westinen, Jussi 2016. Provokaatioita ja vastakkainasetteluja kuka innostuu, kuka vetäytyy? [Provocations and Confrontations: Who Gets Excited, Who Retires?] Available at http://e2.fi/file_attachment/get/provo_net. pdf?attachment_id=30, last accessed on 19 October 2018.

Pöyhtäri, Reeta \& Haara, Paula \& Raittila, Pentti 2013. Vihapuhe sananvapautta kaventamassa. [Hate Speech Narrowing Freedom of Speech.] Tampere: Tampere University Press. Available at http://www.hssaatio.fi/wp-content/uploads/2013/11/ Vihapuhe-sananvapautta..versio_PAINOVERSIO_21.10.13.pdf, last accessed on 28 September 2018. 
Reuter, Mikael 1999. Är hurrin en hurrare? [Do the Hurri Say Hurrah?] Reuters ruta, 8/9. Institutet för de inhemska språken. Available at https://www.sprakinstitutet. fi/sv/publikationer/sprakspalter/reuters_rutor_1986_2013/1999/ar_hurrin_en_ hurrare, last accessed on 24 October 2018.

Riis, Ole \& Woodhead, Linda 2010. A Sociology of Religious Emotion. Oxford: Oxford University Press.

Riksdagen 2015 = Parliament of Finland. Riksdagens skrivelse 54/2014 rd. Medborgarinitiativ: Svenskan som valfritt läroämne på alla utbildningsstadier (MI $2 / 2014$ rd). [Citizens' Initiative: Swedish Instruction Optional in Schools.] 6 March. Available at https://www.eduskunta.fi/SV/vaski/Eduskunnanvastaus/ Documents/rsk_54+2014.pdf, last accessed on 24 October 2018.

Saarikoski, Helena 2001. Mistä on huonot tytöt tehty? [What Are Bad Girls Made Of?] Helsinki: Tammi.

Sakki, Inari \& Pettersson, Katarina 2015. Discursive Constructions of Otherness in Populist Radical Right Political Blogs. European Journal of Social Psychology, Vol. 46, No. 2, pp. 156-170. https://doi.org/10.1002/ejsp.2142.

Sarelin, Mikael 2012. Krigaren och transvestiten: Gestaltningar av mörker och maskuliniteter $i$ finländsk black metal. [The Warrior and the Transvestite: Constructions of Darkness and Masculinities within Finnish Black Metal.] Åbo: Åbo Akademis förlag. Available at https://www.doria.fi/bitstream/handle/10024/87571/sarelin_ mikael.pdf?sequence=2, last accessed on 28 September 2018.

Saukkonen, Pasi 2011. Mikä suomenruotsalaisissa ärsyttää? - Selvitys mediakeskustelusta Suomessa. [What Is Annoying About Swedish-Speaking Finns? - An Inquiry About the Media Discussion in Finland.] Helsinki: Finlands svenska tankesmedja Magma. Available at http://magma.fi/images/stories/reports/ms1101_mikasu_s. pdf, last accessed on 28 September 2018.

Sjö, Sofia \& Häger, Andreas 2015. Filmic Constructions of the (Religious) Other: Laestadians, Abnormality, and Hegemony in Contemporary Scandinavian Cinema. Temenos, Vol. 51, No. 1, pp. 25-44. Available at http://ojs.tsv.fi/index.php/temenos/ article/viewFile/9477/15570, last accessed on 27 September 2018.

Skogerbø, Eli \& Winsvold, Marte 2008. Nettet som debattarena. [Internet as an Arena for Debate.] In: Gunn Enli \& Eli Skogerbø (eds.) Digitale dilemmaer: Nye medieformer, nye utfordringer. Oslo: Gyldendal Norsk Forlag, pp. 39-60. Available at https://www.academia.edu/4717755/Digital_dilemmaer._Nye_medieformer_nye_ utfordringer_2008_, last accessed on 19 October 2018.

Statistics 2017a = Population Structure 2017: Decrease in the Number of Persons Speaking National Languages as Their Native Language Accelerated. Statistics Finland. Available at http://www.stat.fi/til/vaerak/2017/vaerak_2017_2018-03-29_tie_001_ en.html, last accessed on 17 October 2018.

Statistics 2017b = Population Structure 2017: Annual Review 2017, Appendix figure 1. Swedish-Speakers' and Foreign-Language Speakers' Proportion of the Population in 1900-2017. Statistics Finland. Available at http://www.stat.fi/til/ vaerak/2017/01/vaerak_2017_01_2018-10-01_kuv_001_en.html, last accessed on 17 October 2018. 
Stollznow, Karen 2008. Dehumanisation in Language and Thought. Journal of Language and Politics, Vol. 7, No. 2, pp. 177-200. http://dx.doi.org/10.1075/jlp.7.2.01sto.

Strandén, Sofie 2010. 'I eld, i blod, i frost, $i$ svält': Möten med veteraners, lottors och sjuksköterskors berättande om krig. ['In Blood, in Fire, in Cold, in Hunger': War Narration of Veterans, Lottas, and Nurses.] Åbo: Åbo Akademi. Available at https:// www.doria.fi/bitstream/handle/10024/66195/stranden_sofie.pdf?sequence=1, last accessed on 28 September 2018.

Strømmen, Øyvind 2012. Det mörka nätet: om högerextremism, kontrajihadism och terror $i$ Europa. [The Dark Net: On Right Wing Extremism, Counter-Jihad, and Terror in Europe.] Farsta: Molin \& Sorgenfrei.

Suomi24 2016. Suomi24:n sä̈̈nnöt. [The Rules of Suomi24.] Available at http://www. suomi24.fi/opastus/saannot, last accessed on 15 October 2018.

Thiranagama, Sharika \& Kelly, Tobias (eds.) 2012 [2010]. Traitors: Suspicion, Intimacy, and the Ethics of State-Building. Philadelphia: University of Pennsylvania Press.

Townsend, Mark 2012. Breivik Verdict: Norwegian Extremist Declared Sane and Sentenced to 21 Years. The Guardian, 24 August. Available at http://www. theguardian.com/world/2012/aug/24/breivik-verdict-sane-21-years, last accessed on 28 September 2018.

US a = Narttu. Urbaani Sanakirja. [Urban Dictionary.] Available at https://www. urbaanisanakirja.com/word/narttu, last accessed on 25 October 2018.

US b = Bitch. Urbaani Sanakirja. [Urban Dictionary.] Available at https://www. urbaanisanakirja.com/word/bitch, last accessed on 25 October 2018.

Vapaa kielivalinta. [Free Language Selection.] Available at http://vapaakielivalinta.fi, last accessed on 27 September 2018.

Vilkko, Marjo 2014. Suomi on ruotsalainen. [Finland Is Swedish.] Helsinki: Schildts \& Söderströms.

Vuorinen, Marja 2005. Herrat, hurrit ja ryssän kätyrit - suomalaisuuden vastakuvia. [Lords, Hurris, and Russian Henchmen - Finnish Counterparts.] In: Jussi Pakkasvirta \& Pasi Saukkonen (eds.) Nationalismit. Helsinki: WSOY, pp. 246264. Available at https://helda.helsinki.fi/handle/10138/166631, last accessed on 19 October 2018.

Wall, Melissa 2005. Blogs of War: Weblogs as News. Journalism: Theory, Practice and Criticism, Vol. 6, No. 2, pp. 153-172. http://dx.doi.org/10.1177/1464884905051006.

Walton, Douglas 1992. The Place of Emotion in Argument. Pennsylvania: The Pennsylvania State University Press.

Yle 2015 = Finnish MP Calls for Fight against "Nightmare of Multiculturalism", No Comment from Party Leadership. Yle News, 26 July. Available at http://yle.fi/ uutiset/finnish_mp_calls_for_fight_against_nightmare_of_multiculturalism_no_ comment_from_party_leadership/8182155, last accessed on 26 September 2018. 


\title{
CONSTRUCTING ALIEN SPACE IN SOUTH SLAVIC ORAL LYRIC
}

\author{
Ana Vukmanović \\ Independent scholar, Serbia \\ e-mail:ana.vukmanovic@hotmail.com
}

\begin{abstract}
The paper discusses alien space as a construct whose meanings are variable and depend on the assumed perspective, context of singing, and human relations. Alien space is constructed in South Slavic oral lyric as a space of the Other or as the other (liminal) space. The analyzed songs show tension between the alien and own worlds. The alien spaces are marked by relations of alienness and neighborliness. These relations are changeable and limited by the period of the ritual. The ritual context of songs and the ritual inversions of meanings and order make the spatial constructs complex. Oral lyric dominantly subjects the locus to the characters, whereby it has an attributive function. The songs make an analogy between the alien space and the Other. They model alien spaces as unknown, far, fantastic, wild, and dangerous, and as places of death. The paper deals with liminal zones as radically alien. These zones connect or separate own and alien spaces, enabling communication between them. The alien space is constructed as dominantly non-homogeneous and unintegrated, and as such it is an ample reservoir of meanings in oral songs.
\end{abstract}

Keywords: alien space, center, construct, the Other, periphery, ritual, South Slavic oral lyric songs

\section{INTRODUCTION}

This research of alien space was carried out on the basis of the corpus of representative anthologies and collections of South Slavic oral lyric. The reliability of sources was ensured by the academic integrity of editors (Българска народна поезия и проза в седел тола, Българско народно творчество в дванадесет mола, Slovenski narodni pesni, Hrvatske narodne pjesme, editions of the Institute for Literature and Arts in Belgrade) and of those who gathered the songs (Vuk Stefanović Karadžić, Franjo Ksaver Kuhač, I. S. Jastrebov, P. A. Rovinski).

Traditionally, South Slavic oral lyric songs are classified into ritual-costume songs, ${ }^{1}$ labor songs, religious songs, and love and family songs (Nedić 1977: 9-27). However, oral lyric songs are multifunctional and therefore the same 
song, in different contexts, can be classified differently. For that reason, research was carried out on songs of various genres, which are relevant for the topic of spatial construction. During the research it was noticed that the basic models of alien space emerged with similar functions in different genres. It was also noticed that all the models did not emerge in all genres. The way of spatial construction depends on the function of the song and the context of singing. For example, the other space as a space of the dead is typical for laments, and as a liminal zone for the wedding songs. Within the same genre, as in wedding songs, the space of the Other is modeled at different levels (as unknown, faraway, strange, wild, dangerous). Different models of the space of the Other, besides in ritual-costume songs, can be found in love songs as non-ritual.

The research results presented in this paper are based on the representative corpus of South Slavic lyric songs. However, insight into a larger corpus could reveal some new variants of the models of the alien space.

\section{THE NOTIONS OF SPACE}

In oral lyric the notions of space as a fundamental cultural category are formed within the joint activity of the community. During this process, they distinguish between the ritual space and profane space, at the same time also referring to them. Relying on perception, experiences, and adopted cultural models, the singer, when singing, models the space through which he or she moves, or in which he or she resides, humanizing it, thus creating his or her own world. More precisely, the space exists only through the human point of view (cf. Lakoff \& Johnsen 2003 [1980]: 166). Relations to it are complex and ambiguous, and they depend on the function of the song (the context of singing, the assumed perspectives, the relations established in space) and the person's position in it. According to this, the same places acquire different, even opposite, meanings. Within these processes, they are formed as non-homogeneous and are divided into limited/unlimited, closed/open, near/far, and own/alien places.

Fluid meanings reflect the cultural dependence of spatial models. That dependence can be observed in the relations between the center and the periphery, which are revealed as dynamic. For example, the center of the wedding ritual is in the groom's house on which the ritual is focused, since its aim is to bring the daughter-in-law to the new home, but wedding songs can adopt a female perspective and then house is the farthest periphery, an absolute distance on the other side of the mountain or across the water. A human always reveals the center and the periphery as constructs, essentially determined by the human attitude towards them. 
During outsinging, within the same song, the change in the spatial model can be followed. The songs of rejection ${ }^{2}$ intensify the own/alien relation. The bride's family drives away the wedding guests, stressing that the maiden and the land are alien to the guests (Yastrebov 1886: 401). In this song, spatial models are complex because, in the appeal to the wedding guests, the bride's family first takes their perspective, marking their own land as alien, and then they arrogate it to themselves as their land. Through the parallelism, the maiden is associated with the space, and according to that she is defined as alien to the guests and ours to her family. Since the wedding songs are a part of the ritual, during further development of the ritual situation in this song the space briefly changes the master, because the wedding guests occupy it and in that way they get the maiden. When they place the wedding banner in the bride's yard, they occupy the alien space and organize it because from their perspective it is alien, irregular, and chaotic (cf. Eliade 1965: 35). When they leave with the bride, the power over the house reverts to the previous order. ${ }^{3}$

\section{OWN SPACE: THE PERSPECTIVE OF THE OTHER}

When the own world is organized from the perspective of the Other, the spatial construct is emphasized. When the queens ${ }^{4}$ as beings from the distant, ethereal world go around in the village, from one house to another, enter the houses and sit around the dining table (Karadžic 1975: $\left.159^{\circ}\right)^{5}$, they by their movements connect the village, thus performing the magical encirclement, establishing boundaries. Their alterity, which is ritually temporary, is connected with the ritual space and type of landscape, with the ideal land. At the same time, they change the houses and the village where they arrive by ritual acts (cf. Zielinski 2006: 58-59). In fact, the queens themselves as ethereal beings construct the human world during the period of the dual meaning of the ritual period. In that way the village remains a human place, but within the inverse sacred order, it identifies with the distance as well. The farthest distance of the queens' land is getting closer to the human center (dining table) and together they form a spatial construct - all boundaries are temporarily destroyed in the ritual, the positions of the center and the periphery are relativized. The village remains a microcosm during the ritual, but the power of the order comes from the periphery, from the queens' land. ${ }^{6}$

Spatial and personal ambiguity is reflected in the fact that the participants in the procession are village girls and liminal, unworldly beings. They are the Other, different, fantastic, unrecognizable newcomers (cf. Waldenfels 1997: 20). The song refers to them as unmarried, unknown maidens (Kuhač 1941: 272), 
but also as the maidens ready to be married, who pass through the pre-wedding initiation (cf. Kovačević 1985: 129). The ritual order itself considers them as from some other place, even if they appear in their own house, in their own world (Waldenfels 2006: 15). The spatial aspect of alienness is implemented more clearly through the other village from which the bride arrives (Karadžić 1975: $27^{\circ}$ ). These are the reasons why the alienness is thought of as an alien place, as other space, as a place outside the system (Waldenfels 1997: 12). From that specific position, the Other is positioned, in rituals and ritual lyric, as somebody from here, and from far away, from inside and from outside. The queens and newlyweds are simultaneously outside their milieu and inside it (cf. Waldenfels 2006: 112).

\section{ALIEN SPACE AS IDEAL}

Semantic spatial inversion reflects the processes of social and poetical construction not only in constructing the own space from the perspective of the Other, but in constructing the alien space as ideal. Within the spring rituals, the unworldly land of queens is described as ideal. The queens sing to the young woman that they will take away her child if she refuses to pay ransom for him. They will take him to their own land, where two suns are shining, two winds are blowing, because they need him as the basil (Karadžić 1975: $176^{\circ}$ ). The same principle is applied in the construction of the groom's land at the wedding. The bride is asked to come to the groom's land where it does not snow, but only mild rain falls, like summer dew (Karanović 1990: 11º). Both songs stress the fertility and richness of the ethereal world, marked by doubled sun and mild rain, contrasted to the construct of dangerous alien land, which implicitly exists in the traditional culture. Ritual and mythic meanings of the two suns point to the day (celestial) and night (subterranean) orbit of the Sun (cf. Eliade 1958: 136), establishing the vertical solar-chthonic. In that sense, the ideal place merges two worlds. If the songs are compared, the groom's land becomes other-worldly, similar to the land of the queens, and he and his family become analogues to the participants in the ritual procession, which correlate with the common notion of wedding guests as arrogant and mighty (Lilek 1898: 25).

The idealization of the groom's land is performed from the position of culture. The patriarchal community represents it in the songs as more beautiful than the bride's land, as an organized world, symbolized by arranged tables, adorned with golden strings, covered with silver cloths, around which noble mothers- and fathers-in-law sit, as well as the brothers-in-law who are maritime merchants (Karadžić 1975: $5^{\circ}$ ). Although the maiden sings the song, the male, alien space 
is presented as central. Wedding inversion rescinds the distance, and alienness is neutralized by idealizing the patriarchal community. The bride takes the perspective of the new family: by giving priority to the new house, she parts from her own and starts the ritual phase of aggregation.

\section{ALIEN SPACE: LEVELS OF CONSTRUCTION}

Contrary to the semantic inversion, the construct of own/alien space usually corresponds to the oppositions good/evil, and safe/dangerous. The processes of the spatial construction can be traced in the acts of organizing the world. Just when the human, in the cultural process, builds up his or her residence and fences it, the water, forest or mountain can become external, alien, and hostile. These characteristics are not imminent to them. The perception of the external space is permanently penetrated by intuition (cf. Cassirer 1955: 104). As the notion of the world is performed from the first person's point of view, Husserl (as cited in Waldenfels 1997) shows that here forms the zero point on the basis of which the spatial system is formed, including the relations of the center and alterity/alienness. The relation "I am there where you are not" represents the relativity (spatial - A.V.) of the alienness (Waldenfels 1997: 194-195).

On the other side of the border there is somebody else's, alien world. It is open but limited as well, determined by crossings and obstacles, relations of neighborliness and alienness (Waldenfels 1997: 195). The alien space as a space of the Other can be human or inhuman, but it is always organized in a way, and analogous to the cosmos. It is encoded twice - it is determined by relations of closeness and distance, known and unknown, one's own and someone else's. ${ }^{7}$ On the other hand, the alien can be the other space. That other space can be a land of the dead or a liminal zone. In both cases it is mainly inhuman, opposed to the own space, as well as the space of the Other. As the radically alien, they are outside the order; a non-place cannot be registered in the network of places and it shows inaccessibility of a radical kind (Waldenfels 1997: 187).

The opposition "the space of the Other / other space" can be noticed in the example of the wedding songs. Although the bride's and groom's houses are essentially different, the difference is established through the opposition own/ alien, which depends on the perspective and in fact is built on the principle of "symmetry of the mirrors" - alien space has the same structural characteristic as one's own, but their direction is opposed, so they can be seen as isomorphic (Karanović 2010: 150). However, wedding songs, during the liminal phase of the ritual, have the need to stress this otherness, even when the groom's land is modeled as ideal. Ritual acts of the bride's separation from her home and 
of her adoption in the new one (saying good bye to the hearth / salutation to the hearth - Đorđević 1984 [1923]: 268; Čajkanović 1994a: 154) refer to the existence of the two worlds that are occasionally different. An especially emphasized position of one's own and the announcement of the possible change within the pair "one's own / alien" appears when the maiden in the song asks for forgiveness - she asks her family to let her go, to leave the home, as well as the golden table as a center and a symbol of her old world (Nikolić 1888: $7^{\circ}$ ). In order to arrogate the alien, groom's world, the bride needs to be separated from her own during the separation phase of the wedding.

Alien space as a space of the Other in South Slavic oral lyric is constructed at different levels: as unknown, faraway, strange, wild, and dangerous.

\section{ALIEN SPACE AS UNKNOWN}

Oral lyric constructs the alien space as primarily unknown. A young man sings about a horse which brought him to the white castles, fenced with pine trees, where the maiden lives. She sweeps the castles with a little needle traditionally used for embroidering handkerchiefs (Karadžić 1898: 466 ${ }^{\circ}$ ). He arrives in an indefinite - someone's - world situated in the pine forest, which points to the inhuman nature of the castle. Alienness is alleviated by the attribute white, which gives it the characteristic of lightness. However, white can be associated with the incorporeal, in which case the castles would be radically other-worldly (cf. Radenković 1986: 8-11). This ambiguity of the attribute marks the alien space as ambiguous as well. When the unknown maiden sweeps the floor, she organizes the world. Her castles are somewhere else, but it is not outside the order - the order can be recognized, and the young man places it in a particular system where the wild, open (pine forest), and the own, fenced (swept castles), are juxtaposed. The ambiguous notion of alterity (in this case - the alterity of the maiden) is formed by the spatial code.

The unknown space is connected with the motif of abduction. When the young man abducts the maiden, he takes her to his world, which is distant, alien, and unknown to her. The maiden enters the garden and falls asleep among roses and carnations. The young man comes to mow, sees the maiden, leaves the scythe, steals the maiden, and takes her to the alien, unknown green mountain (Osinin \& Burin 2006: $347^{\circ}$ ). While the maiden is passive (sleeps, and then she is an object of abduction), the young man actively establishes a relationship with two spaces - he mows the garden, organizing the world, and takes away the maiden into the green mountain, disturbing the social order. He moves through the human, fenced, own garden, and through the inhuman, open, wild mountain. The 
mountain is unknown to him as well, but it is accessible. This kind of complex relation between the young man and the locus corresponds with the fact that he, in the liminal phase, crosses the boundaries between the own and the alien easily, because he belongs to both spaces, or does not belong to any of them.

\section{ALIEN SPACE AS FARAWAY}

On the second level, the alien space is far away. The distance is constructed by the human perception of the physical (corporal) capabilities (Mršević Radević 1996: 397). It is different from the place where we stand, and the songs construct the notion of distance in contrast to the house as a close place (Maltsev 1989: 141). As unknown, the other man is alluring but dangerous - in the same way the distance is the space of longing, which should be conquered and tamed, and the dangerous space where the man should protect himself. The formula at the distance, which is the poetical "trigger" for the existential and ontological uncertainty of the liminal situations, carries a semantic potential of alienness.

The most typical model of distance is the three-part structure "mountainwater-field". The maiden calls the brother's horses to eat and drink because a long way to the bride awaits them - three high mountains, three deep waters, and three wide fields (Andrić 1929: 255 ${ }^{\circ}$. Besides the distance, this model holds the cosmic dimensions of height, depth, and width, and the wedding guests mark the boundaries of the world by moving through the space. The multiplication of structures represents a typical folklore pattern and stresses the impassableness. Another folklore pattern is number nine. The daughter begs for forgiveness because she is going far away, across nine deep rivers, nine wide fields, nine big mountains, and nine villages to arrive at the groom's - the tenth - village (Ivanova \& Zhivkov 2004: $397^{\circ}$ ). This variant includes the forth spatial entry, represented by the village, and in it the song deviates from the numerical structure because it emphasizes the tenth village as the end of the ritual journey, which is the space of the maiden's new home.

Since it is hard to surmount the distance, because it is isolated, inaccessible, and unknown, it is also difficult to communicate with it. As it is very far, it is a dangerous space of disappearance (Mršević Radević 1996: 399). A variant of the song about the path of the wedding guests constructs the distance as impassable. It emphasizes the power of the wedding guests over the space, so they gain characteristics of supernatural beings, capable to pass through the mountain, although the deer which belongs to the wild world cannot do it, and to cross the wide waters, which the fish cannot swim across (Štrekelj 1904: $\left.5440^{\circ}\right)$. The hyperbolas are frequent figures in oral lyric. They contribute to 
forming the lyrical world, expressing feelings; they are the recourses of lyrical fantasy, and in this case they emphasize the capability of wedding guests - the spatial construct itself is subordinated to that function. ${ }^{8}$

Distance is constructed by temporal models as well. The horse needs a day for gaiting, the hero two days for walking to reach the maiden's land (Rajković 1869: $141^{\circ}$ ), or the journey takes three days across the field and four across the sea (Petranović 1989 [1867]: 183º), or the maiden is forty overnight stays far from the young man (Andrić 1929: $281^{\circ}$ ). Temporary coding can be combined with the spatial one: the hero rides a horse through the mountains, he travels and hunts for three days and eventually he hunts down the maiden (Miladinov, D. \& Miladinov, K. 1961: 599). The mountain is a symbol of the other, chthonic, inhuman space. As emphasized, its distance marks these characteristics. The maiden as a catch, as a wild being, becomes an alteration of space. She is different from the young man because her residence is inhuman, far from the young man's world. The spatial code is dominant, so the maiden's otherness is not alleviated by adornments.

The image of the circular growth of the sour cherry tree forms a special spatial model from a temporal perspective. The sister-in-law consoles the maiden who awaits the wedding and tells her that the sour cherries were planted when her future husband's family visited her home for the first time; when they came to ask for her hand, the sour cherries were in blossom, when they came to take her away, they were eating sour cherries (Karadžić 1975: 414º). The cycle of growth of the plant corresponds to the maiden's life cycle, more exactly to the phase of the wedding as a ritual of passage. The construct of the distance is determined by emotions: the maiden's fear and the sister-in-law's tranquility. Uncertainty increases the distance, and the position of acceptance of the new house as one's own disparages it. The relation between two sisters-in-law dynamizes the meaning of the distance, and implicitly positions the two houses both in spatial and ritual sense.

The notion of distance is constructed by activating the symbolic potential of water. Ethnographic material records that the Serbs did not easily give away their daughters across the water even if that meant only a rifle range distance from the house (Popović 1950: 261). This note confirms that the distant space is a construct, that has just loose connection to the physical reality. The differentiation of the space by establishing boundaries is conducted by human emotions in the encounter with the Other (cf. Cassirer 1955: 95). The water does not have to be a less known space, but it certainly is different than the village and the house. When the wedding song is sung from the maiden's perspective, wedding to the distance is condemned, and it is marked by the sorrow of the family who loses one member, as well as of the maiden who leaves the house and cannot get 
over the fact that her mother gave her away to the distance, across the Danube River (Bušetić 1902: $82^{\circ}$ ). Different emotions follow the wedding and merge with the motif of a dangerous passage, which becomes the sign of the change.

On the other hand, mythical thought rescinds the spatial distance because the distant merges with what is close at hand, thus being essentially the same (Cassirer 1955: 91). This is the case in the song that speaks about the falcon that flies through a narrow gorge. When the falcon asks if the maiden's castles are far away, it gets an answer that they are neither far away nor close, but the castles are where the maidens are singing and the bread is being baked (Ivanova \& Zhivkov 2004: $292^{\circ}$ ). Opposed to the gorges as clearly wild and hardly passable, there are the maidens' castles as completely pleasant, with the sounds of maidens' songs. They are made cosmic by bread-baking (Ivanova 1998: 9). This kind of ambiguous space - faraway and pleasant - shows that the distance is not fixed. It can be overcome by moving; no matter if the wedding guests are travelling through the wild space or the falcon is flying over it. In this way, the close space is moving away, the faraway one is moving closer, and the hypothetical alien, in certain circumstances, becomes familiar (cf. Karanovic 2010: 150). The usual notion of the bride as a dangerous being from the other world is also a construct, because she is, from this perspective, alien and distant; she is not dangerous, but tame.

Even if the maiden comes from the other side of the boundary, thus being clearly from the other world, she can become dear and gladly expected. The young man falls in love with the maiden who is like an iris brought from the other side of the mountain, across the white Danube, and planted in the garden below the privet. A thin and tall fir grows from the iris, from its peak dew drops, from the root the Danube flows (Benovska-Sabkova 2005: 203 ${ }^{\circ}$ ). Potentially a wild, mountain being, arriving from across the water, is now being cultivated through the parallelism with the iris planted in the young man's garden. No matter how much alterity (other-worldliness) is spatially emphasized, it is disparaged by stating love and, by that, human feelings change the nature of the mountain and the Danube. The contrast between the mountain and water, on the one hand, and garden on the other, is annulled in the cosmic notion of a fir tree as axis mundi, which connects three worlds - subterranean, earthly, and celestial, that is, the maiden's and the young man's.

In the ritual song, lazarice $^{9}$ speak with pigeons, inviting them to come in the spring time when the family wishes to marry the son/daughter to the maiden / young man from far away (Veselinović 1890: 72-74). ${ }^{10}$ The positive connotative meaning of the wedding to the distance can point out the advantages of exogamy. When the song emphasizes the positive distance as wild - the girls in a ritual procession sing that if the family does not marry the young man, he 
will escape to three mountains and four turfs, where he will find a maiden and bring her home (Yastrebov 1886: 112-113) - it presents an inverse ritual order. The maiden and the young man, in the liminal phase of the initiation ritual, gain from the distance the power of alien spaces, above all, fertility.

When the different values of distant spaces are compared, the constructed relation to the Other, no matter if it is coded by a personal or spatial code, is shown as complex, potentially contradictory. The other space, as the Other in general, is ambiguous - equally dangerous and desirable.

\section{ALIEN SPACE AS STRANGE}

Strangeness is the third level of alterity. It is not only unknown to the people, but also unintelligible. However, a strange young man is not necessarily undesirable. An inverse spatial model is constructed: the strange hero passes the village, dressed in strange clothes. He wears a Hungarian belt and carries Turkish knives. He asks the fair maiden to lead him out of her village, to the green mountain (Popović 1888: 21, $1^{\circ}$ ). The local, organized village is unknown to him. In order to surmount the space, he needs help of the village girl, alien to him - maybe strange. He wishes to go out to the open, wild, green mountain. Strangeness formed by the ethnic code originates from the more recent times (the ethnicity of the young man is not clear). The perspectives intervene and reveal mutual strangeness: from the perspective of the villagers he is strange, from his own perspective - the village is impassable. The flexibility of the construct of one's own and alien is necessary for communicating with the Other, for the young man and the maiden to get in touch. Just when the polycentric world exists, there is a possibility of understanding.

\section{ALIEN SPACE AS WILD}

The wilderness represents the fourth level of the alien space. The maiden grew up in the wild space, in back of the mountain, below a poplar (Rovinski 1994: $511,2^{\circ}$ ). Although she comes from the other side of the boundary (mountain), and because she is other-worldly, the maiden knows the human world of dancing songs. She participates in the sacral/profane decoration of dancers with poplar leaves. In contrast to the previous song, where the mountain is unknown to the young man, in this one the opposition between one's own and alien is relativized since both - the open space in back of the mountain and the village - are familiar to the maiden. The wilderness, as well as the distance, although inhu- 
man, does not necessarily need to be marked negatively: the space behind the mountain, below the poplar, is tamed by a possessive adjective (my) so that the maiden, although alien, is to be the young man's maiden.

As distant and wild, the space possesses special powers. In lullabies the space is apotropaic. The mother sings to her son, wishing him to fall asleep. She is telling the story of how the mother gave birth to him in the mountains, among wolves; a white fairy was the midwife, a she-wolf cut his umbilical cord, and a doe nursed him with milk (Rovinski 1994: 514, 11 ${ }^{\circ}$ ). As the child was born in the mountains, he gained the powers of the wild world, for example, the strength of wolves. He received the strength from a doe's milk as well. Since the fairy was the midwife, he would be under her protection, and he is thus transformed into a half-demonic being. The magical function of the lullaby constructs the notion of desirable wilderness, and the opposition human/inhuman is not determined by value. If it were, then the inhuman, alien world would be mightier than the human.

\section{ALIEN SPACE AS DANGEROUS}

Danger represents the fifth level of alterity. The dangerous space is, above all, modeled by incantations. ${ }^{11}$ Their spatial model is subordinated to the function of protection from the evil forces, demons, and illnesses, which they drive away to the wild places. The weed - the white Saturday, the sister of hail, fell in the field and there let the hair grow to cover the field. The incantation says that the field is no place for her, that she has to go to the bleak mountain, into the deep water, where there are no people, where the rooster does not crow, hens do not cackle, oxen do not moo, and sheep do not bleat (Yastrebov 1886: 175). The human, cultivated space of fields is opposed to the wild, unfertile spaces of the mountain and water. The incantations model wilderness as radically inhuman, soundless. Not only do humans not live there, but it is a residence of dangerous forces and demons.

Contrary to incantations, the lyric song transforms the groom's land into a demonic, and therefore dangerous, place. The maiden was given away to the ninth village, across nine high mountains, nine green forests, nine big rivers, and nine cold fountains - where roosters did not crow and lambs did not bleat (Yastrebov 1886: 216-217). The wedding leading to the voiceless spaces corresponds to death. The formula of a black mountain activates negative connotative meanings and emphasizes the impassableness of the mountain, which the maiden cursed because her mother married her to the distance against her will (Andric 1929: $231^{\circ}$ ). Periphery is dangerous for the bride and for the groom, 
but on this occasion hostility towards that space is transferred to the other alterity - to the new house. By cursing the mountain, the bride endangers the fertility of the new family.

The image of the completely impassable forest in the song stresses the danger. The maiden is asked to drive away wolves through the thick forests. She answers that she is afraid, that her hair is long and gets tangled in blackberry and raspberry bushes, and in Peter's apple (Jovanović 1926: 52, $1^{\circ}$ ). It is expected that the maiden, whose name is derived from the noun 'wolf' (in Serbian: Vukavuk), should have power over wolves. Like wolf men, ${ }^{12}$ she needs to drive wolves away and protect the village. ${ }^{13}$ Nevertheless, she denies having this power. The fear of wild animals is constructed by the wild space, more precisely, by thorny plants in which the maiden's hair is hooked. The final verses move the spatial code from wild to tame, and by that the symbolism of the wedding and love in the song is strengthened. Contrary to the dangerous space of the forest, the apple appears in it. Although the maiden's hair is hooked in it as well, the apple is qualitatively different from blackberry and raspberry, because as a fertile tree, it belongs to the organized human world (Radenković 1986: 198).

Especially dangerous places are marked by taboos. The young shepherd cries out to the maiden not to drink cold water from the well in the green mountain because fairies bathed the child there and poisoned the water (Kuhač 1941: $274^{\circ}$ ). The taboo protects the maiden from the poisoned water, but protects the sacred place from the maiden as well. When the well gets in contact with a demonic being, it becomes sacred. Only in a specific context the spring is dangerous for the people who belong to the profane sphere. When we think about the spatial construct, it is important to pay attention to processes of formation of the spatial complexes: spring - tree, spring - fairy's ring, river bridge, river - water mill, river - fish (Bandić 1980: 263) or mountain - well. Within them, the spatial image is widened and the coordinates of one (sacred) world are established.

The alterity is not dangerous just for the maiden, but for the young man as well. When he sets off for the bride, he begs for forgiveness and blessing from his mother since he will go to the alien village, for the alien sister - his beloved (Karadžić 1975: $27^{\circ}$ ). The complex of alterity is formed out of place and being. While the space of otherness remains alien, the alien sister is transformed into the young man's beloved. In that process she is arrogated, adopted in the young man's own world, because the ritual passage needs to be carried out. The groom does not arrogate the space, and it is not transformed. It remains dangerous and for that the young man needs special protection of blessing on the road through the alien land. The space remains the same after the wedding ritual. 
The tension between one's own and alien is modeled by relations between sexes. When the mother worries that the maiden will lure her son, the son answers that the maiden will not lure him because she carries water from his well, picks the flowers in his garden, lauds the wreath in his chambers and puts it on his bed (Osinin \& Burin 2006: $189^{\circ}$ ). The young man acquires power over the maiden during her stay in his space, the house, and the garden. In other words: the maiden loses her powers when she enters the alien space. From this position, the space is constructed as a magical remedy/weapon, which provides victory for the young man in the love game and, in a broader sense, in human relations. When the maiden enters the young man's yard and garden, and even the bedroom, she becomes his. One's own space tames the alien being.

\section{THE DYNAMIC OF SPACE}

Oral lyric expresses the spatial dynamics by modeling images of movements. The road represents a specific topography of boundaries (Ivanova 1987: 80). When the maiden parts from her family because the alien brothers take her away, her brothers accompany her to the enchanted mountain, to the cold water, and to the white castles (Karadžić 1973: 60). Although the image presents the separation ritual, the song constructs a complex of porous boundaries. Her brothers succeed in surmounting the mountain and the water as hard boundaries between two worlds, and arrive in front of the groom's white castles. There they stop. The occasional porousness of the mountain and the water shows the instability of the construct, but it emphasizes the otherness of the groom's home, which is, in this context, more radical than the wild interspaces. The pair brothersin-law / her brothers points to the ambiguous model of the road - while the brothers-in-law are the guides during the ritual passage, her brothers are an escort which provides protection of one's own world and represents a temporary resistance to the new reality. Both of them follow the same path, but for the groom's brothers it is a return to the known, whereas for the bride's brothers it is the path of the final separation, emphasized as the other and wild. The dynamic of the space is reflected in passages which change the man, but the space is changing itself as well. When the brothers accompany their sister-bride across the mountain and water to the white castles, and when they separate from her in front of the groom's house, they pass over the cosmic boundaries. From unmarked young men they become liminal beings - guides. The maiden, whose otherness is emphasized, is changing as well. When she enters the new house, she is finally separated from her family, she is not a part of it anymore, but of the other family, she is not a sister/daughter, but a sister-in-law / wife. 
The brothers become the others, and within the new order the brothers-inlaw, by that moment alien brothers, become hers. The spatial model shows the changes of human relations, above all, because the bride has changed. The maiden's passage inverts the nature of the space - the groom's (white) castles, initially alien, become her own.

Although the mountain is dominantly unearthly and dangerous, the ambiguity of the spatial construct enables the activation of contrastive meanings. Opposite to the dangerous and wild mountain, there is a fertile apple mountain. When the wedding procession leads the bride across the mountain, apple trees grow there; when the bride crosses the water, it flows with wine, and the village that she enters is a happy, healthy place (Karanović 1999: $23^{\circ}$ ). When, as in this song, fertility and creation of the new family are emphasized, the locus makes the bride a powerful being, who tames the unearthly world, bringing prosperity to the new family.

\section{THE OTHER SPACE}

While the mountain/road is stressed as liminal and inhuman, the notion of the other space is modeled in the song. That other space is opposite to the space of the Other. The typical other space is the boundary. The boundaries establish the institution of the zone (no man's / every man's land). They are sacred to the inhabitants of the territories around it, and the man who is in the zone hovers between two worlds (Van Gennep 1981 [1909]: 24-25). The zone establishes relations with other spaces, one's own and alien, it does not belong to either of the worlds that it separates, and in this way its otherness is emphasized. The lyrical songs model the separation of the liminal world from the human one by the motifs of the high mountain, deep water, and wide field. Liminal space is inversed in relation to the human world and different rules apply in it (Turner 1969: 167). For that reason, the maiden can be active on the road and, for example, ferry the wedding guests across the sea, and show herself as a master of the water (Karadžic 1975: $74^{\circ}$ ). When the groom or the bride crosses the water (sea, river, bridge) or mountain (forest), their otherness and inhumanity are additionally marked.

As much as the bride's home is alien, even unworldly to the groom (or the groom's home to the bride), this alterity and otherness are human, and by that essentially different from the meaning of the road as inhuman. The road, marked by the mountain and water, does not have any mutual characteristics with the house - it is no man's domain. It is especially marked because in the mythopoeic image of the world it connects two contrasted, mutually distant 
spatial points, no matter whether it is orientated horizontally or vertically (Detelić 1992: 111).

The meadow, valley, or field represent the first part of the road, the one closer to home - they are partially organized, yet uninhabited spaces. They are limited, but have ambiguous meanings. In them, a wedding procession can get in touch with good as well as with evil forces (cf. Detelić 1992: 46). When it moves away from the house, it arrives in the mountain spaces, which are dangerous and unorganized, associated with demons, and therefore contrasted to the home. Because of that, they are unfriendly to man, chthonic and alien. In chromatic code, green is the color of the first phase of the journey, and black is the color of the second phase. The colors in the process of cultural coding gain abstract meanings of the sign (Karanović 2010: 148).

The mountain is the most typical construct of the interspace. It is inhuman to the utmost and does not have any similarities with the house, even if it is an alien house (e.g. the groom's house). Its danger is constructed by taboos. The mother advises her daughter not to tease the mountain when she passes through three green mountains - one ash tree and two fir tree forests, not to let the horse wet the hooves when they cross the water and not to raise the dust on the road (Yastrebov 1886: 357). If she does not tease the mountain, the maiden respects the speaking prohibition. She does not draw the attention of impure forces, demons, and spirits, who live in that space, to herself. If the horse does not wet the hooves, it will not set the natural power in motion. If the horse does not raise dust on the road, they will pass through this liminal space unnoticed. The multiplication of spaces and emphasis of impassableness by the motifs of fir and ash forests additionally mark liminal, wild space. The three-part model of the forests is part of a more complex three-part model "mountain - water road", and it establishes order in the inhuman, alien world. The result of this is that the interspace, even if it is alien, is not necessarily the same as chaos.

The next song models the ritual ordinance of covering the bride. The maiden asks the godfather and Saint John to put a veil over her head because she is going to pass through the thick forest of lilies. The wind blows and it uncovers her (Arnaudov \& Vakarelski 2004: $387^{\circ}$ ). The uncovered, beautiful face in the chthonic space attracts spells and impure forces, which can bring death to the maiden (Van Gennep 1981 [1909]: 241). The ritual act of covering the bride forms the notion of a mountain as a dangerous and wild place. This poetic modeling of the ritual shows that a spatial construct can be formed by different codes (in this case by action code).

One liminal place does not always have the same meaning. The meaning depends on the spatial model and the function of the space in the song. When the image is set between two mountains, between two cold waters, where the 
maiden fell asleep, laying her head under the rock where a snake is hidden (Miladinov, D. \& Miladinov, K. 1961: $235^{\circ}$ ), the danger is even bigger because the spatial liminality is doubled - the mountain itself is liminal, but the passage between the two mountains is situated between two boundaries. While the danger is only indicated in the previous example, here it is clearly marked by the motif of snake. The peril is emphasized by both the locative code (by the chthonic mountain) and the zoomorphic one (by the snake as a chthonic being).

\section{THE SPACE OF THE DEAD}

The world of the dead in laments represents the culmination of alterity. It loses ambiguity and is completely inhuman and evaluated as negative. It is a far space where roads without return lead (Karadžić 1975: 151), from where no man can ever arrive (Karadžić 1898: $125^{\circ}$ ), because there is no return from that world. It is qualitatively different from the space of the Other in wedding songs, represented by the groom's/bride's home, as well as from liminal zones, from where the man can return safely. As a world of darkness, it is radically opposed to the white world of the living. While two suns shine in the ideal land, there is no shining sun in the town of the dead (Karadžic 1898: 125). Contrary to the width of the fields, there is a narrow and tight space of laments, the space without doors and windows (Karadžić 1975: 153º), which points to the coffin. While the spaces of oral lyric are ample, rich in water, the world of the dead is infertile and arid (Karadžić 1898: $125^{\circ}$ ), or the water in it is dead and chthonic (Karadžić 1898: $126^{\circ}$ ). As the enchanted world of the Other, it is strange (Karadžić 1898: $143^{\circ}$ ), but the meaning of that strangeness is radical since it is not the human world at all. It does not provoke curiosity, but invokes the horror of the laments. It is populated not only with the dead, but with snakes as chthonic beings which drink the eyes of the dead people (Karadžić 1898: $126^{\circ}$ ). The space of death is formed by various codes as a complex construct - marked by human sadness and fear in encounter with mortality.

\section{CONCLUSION: THE SPACE OF THE OTHER AND OTHER SPACE}

The notions of space in South Slavic oral lyric are dynamic and depend on the context of singing and the perspective taken in the song. In that sense it is possible, as in the case of the queens' songs, to model own space from the perspective of the Other. On the other hand, in the inverse ritual conditions the alien land can be modeled as ideal, when the perspective of the Other is taken 
once again. As it is shown, liminal space is not homogenous and integrated, but differs from one's own space in the way that depends on whether it is the space of the Other, a liminal, inhuman zone, or the land of the dead. In the first case, it can be conquered and then its structure is analogous but inverse to the structure of one's own world. The space of the Other can be unknown, faraway, strange, wild, and dangerous. It is always connected with one's own space and often constructed as its reflection in the mirror (Karanović 2010: 150). In the second case, the liminal space can be surmounted, but remains open and amorphous. The other space, regardless of whether it is the liminal zone or the world of the dead, is qualitatively different than the human world. Spatial dynamics is established not only poetically, but by the change of the perspective, by the movements of heroes and heroines. The lyrical alien spaces represent discontinuity and understand the tension that oral lyrics do not dissolve since their poetics does not require it. Their meanings always depend on changes in people and interactions that people enter with each other and with places.

\section{NOTES}

1 South Slavic ritual-costume songs are characterized by a number of genres. In this paper lazarice songs, kraljice (queens') songs, wedding songs, lullabies, and laments are mentioned.

2 Songs of rejection are a genre of wedding songs. They are sung when wedding guests arrive in the bride's home, and they have a ritual function to temporarily withhold guests. In that sense, songs are analogous to a locked door and different kind of barriers that await wedding guests (Ajdačić 1998: 222).

3 The imagined value difference our land-alien land (the land of the Other) does not require that the Other accept that distinction. It is enough to set the boundary, which in the song is represented by sticking the banner in the yard. People start to fill the alien space beyond the own with different suppositions, associations, and fictions (cf. Said 1979 [1978]: 54). In the lyric songs the meanings of these suppositions, associations, and fictions vary from fear and resistance to desire and welcome.

When the insights of the post-colonial theory are used, it is done knowing that there are limitations on its application to traditional culture. However, it seems that, for discussing spatial models (space of the Other and other space), these insights are inspiring and useful. Although there are different contexts in question, it is noticed that, above all, in the case of ambiguous attitudes towards the Other and towards the liminal space, there are analogies with the post-colonial understanding of the Other and of the Third space.

4 Queens (kraljice) is a spring ritual that takes place at Pentecost in the form of processions of specially dressed and equipped female groups. Queens' songs are sung during the ritual (Nedić 1977: 16; see also Jokić 2012). 
5 For precise citations, the number of the song in the collection is given in the parenthesis; it is marked by the ${ }^{\circ}$ sign.

6 The queens establish the space as cosmic by encirclement. But when they move through the village, they sing about other spaces, maybe describing the queens' path in the past (cf. Jokić 2012: 67).

7 Like in the oral lyric, where the ambiguous relations with the Other are established, at the end of the twentieth century, space and time crossed to produce complex figures of difference and identity, past and present, inside and outside, inclusion and exclusion (Bhabha 1994: 1). The Other, as well as the place of difference and otherness, is never entirely on the outside or implacably oppositional. It is a pressure and a presence (Bhabha 1994: 109).

The figures of the Other in the modern world and in the traditional culture have some similarities but they are significantly different since the alterity in a ritual context is temporary and in a post-colonial context it is permanent. The identities of the participants in the ritual (bride, groom, queens, lazarice, etc.) are marked by temporary difference regarding the community. During the ritual, they exist between the past (previous stage of their lives) and the present (new position in the community). The ritual is a point of change when they cease to be what they were and gain new social roles. They are excluded and are members of the community at the same time (Van Gennep 1981: 37). The heroes and heroines of the ritual-costume songs have the same existential status.

The space of the Other in oral lyric is also ambiguous and depends on the perspective. The other space, although opposite, is in interaction with the own space in the traditional world image. They establish relations based on analogy rather than on contrast.

8 The verses that emphasize the maiden's power to surmount the distance have the same function. The maiden, barefoot and bareheaded, passes as a man through seventyseven towns covered by snow, which stand in her way (Rajković 1869: $5^{\circ}$ ).

9 The lazarice, as queens, are a female ritual group, who go in procession around in the village on the Lazarus Saturday, before Easter. The lazarice songs were sung during the ritual (Nedić 1977: 14).

${ }^{10}$ In a variant, water is a symbol of distance. If it is meant to be, the family will marry the son to the maiden from the distant land situated across the cold water (Popović 1888: $25,2^{\circ}$ ).

${ }^{11}$ In this case, in a comparative context, the attention is drawn to the spatial model in the incantation as well. Based on the function, the spatial model in the lyric song and in the incantation are contrasted. The incantation is singled out because it has a structure similar to that of the lyric song, and some of the incantations can be found in lyric collections (cf. Petranović 1989: 43º).

${ }^{12}$ Wolf men (vučari) are the male ritual procession that goes around in the village (sometimes wearing masks), carrying a killed wolf or a wolf's skin. The ritual has an apotropaic function of protecting animals and people from wolves (Tolstoi 1995: 460). 
${ }^{13}$ Since the song was classified as queens', at the time when it was written down, it could have referred to the connection with the wedding ritual. The queens' ritual is connected with the wedding initiation, because the girls ready to get married are presented to the village in the queens' procession (Karanovic 2010: 89-90). Wolves could be the groom's male friends (Gura 1997: 126). In that case, it would be requested from the maiden to establish a relationship with the new community by a ritual refusal of the wedding guests. Her denial of capability to fulfill the task would mean the passage to the new family. The apple is another wedding symbol whose ritual potential is exceptional - it is a symbol of the maiden, a gift, and a ritual object (Čajkanović 1994b [1985]: 92-99, 233-236).

\section{REFERENCES}

Ajdačić, Dejan 1998. Žanrovi svadbenih pesama. [Genres of Wedding Songs.] Kodovi slovenskih kultura, No. 3, pp. 218-238.

Andrić, Nikola 1929. Hrvatske narodne pjesme. [Croatian Folk Songs.] Vol. VII. Zagreb: Matica hrvatska. Available at https://archive.org/details/ HrvatskeNarodnePjesmeKnjigaSedmaMaticaHrvatska/page/n1, last accessed on 9 October 2018.

Arnaudov, Mihail \& Vakarelski, Hristo 2004. B’lgarsko narodno tvorchestvo v dvanadeset toma. [Bulgarian Folklore in Twelve Volumes.] Vol. V. Obredni pesni. [Ritual Songs.] Varna: LiterNet.

Bandić, Dušan 1980. Tabu u tradicionalnoj kulturi Srba. [Taboo in the Traditional Culture of the Serbs.] Beograd: BIGZ. Available at https://www.scribd.com/ document/64389127/Dusan-Bandic-Tabu-u-Tradicionalnoj-Kulturi-Srba, last accessed on 30 October 2018.

Benovska-Sabkova, Milena 2005. B'lgarska narodna poezija i proza v sedem toma. [Bulgarian Folk Poetry and Prose in Seven Volumes.] Vol. V. Ljubovni pesni. [Love Songs.] Varna: LiterNet.

Bhabha, Homi K. 1994. The Location of Culture. London \& New York: Routledge.

Bušetić, Todor 1902. Srpske narodne pesme s melodijama iz Levča. [Serbian Folk Songs with Melodies from Levac.] Beograd: Srpska kraljevska akademija.

Čajkanović, Veselin 1994a. Studije iz srpske religije i folklora 1910-1924. [Studies in Serbian Religion and Folklore.] Beograd: SKZ \& BIGZ \& Prosveta \& Partenon.

Čajkanović, Veselin 1994b [1985]. Rečnik srpskih narodnih verovanja o biljkama. [Dictionary of Folk Beliefs on Plants]. Beograd: SKZ \& BIGZ \& Prosveta \& Partenon.

Cassirer, Ernst 1955. The Philosophy of Symbolic Forms. Volume Two: Mythical Thought. Transl. by R. Manheim. New Haven: Yale University Press \& London: Geoffrey Cumberlege, Oxford University Press. Available at https://monoskop.org/images/f/ f3/Cassirer_Ernst_The_Philosophy_of_Symbolic_Forms_2_Mythical_Thought. pdf, last accessed on 9 October 2018.

Detelić, Mirjana 1992. Mitski prostor i epika. [Mythical Space in the Epic.] Beograd: SANU \& Autorska izdavačka zadruga. Available at http://www.academia.edu/1378181/ Mitski_prostor_i_epika_Mythical_Space_and_the_Epics_SANU_Beograd_1992, last accessed on 9 October 2018. 
Đorđević, Tihomir 1984 [1923]. Naš narodni život. [Our Folk Life.] Vol. 1. Beograd: Prosveta.

Eliade, Mircea 1958. Patterns in Comparative Religion. Transl. by R. Sheed. New York: Sheed \& Ward.

Eliade, Mircea 1965. Le sacré et le profane. Paris: Gallimard. Available at https://monoskop.org/File:Eliade_Mircea_Le_sacr\%C3\%A9_et_le_profane_1965.pdf, last accessed on 9 October 2018.

Gura, Aleksandar 1997. Simvolika zhivotnykh v slavianskoi narodnoi traditsii. [The Symbolism of Animals in Slavic Folk Traditions.] Moscow: Indrik. Available at http:// inslav.ru/images/stories/pdf/1997_Gura.pdf, last accessed on 9 October 2018.

Ivanova, Radost 1987. Traditional Bulgarian Wedding. Transl. by N. Panova. Sofia: Svyat Publishers.

Ivanova, Radost 1998. Svadba kao sistem znakova. [Wedding as a System of Symbols.] Kodovi slovenskih kultura, No. 3, pp. 7-13.

Ivanova, Radost \& Zhivkov, Todor Iv. 2004. B’lgarska narodna poezija i proza $v$ sedem toma. [Bulgarian Folk Poetry and Prose in Seven Volumes.] Vol. II. Obredni pesni. [Ritual Songs.] Varna: LiterNet.

Jokić, Jasmina 2012. Kraljičke pesme: Ritual i poezija. [Queens' Songs: Rituals and Poetry.] Beograd: Društvo za srpski jezik i književnost Srbije.

Jovanović, Drag P. 1926. Kraljičke pesme. [Queens' Songs.] In: Kićine pesme. [Kica's Songs.] Beograd: Uredništvo Kiće, pp. 49-55.

Karadžić, Vuk 1898. Srpske narodne pjesme. [Serbian Folk Songs.] Vol. V. Beograd: Državno izdanje.

Karadžić, Vuk 1973. Srpske narodne pjesme iz neobjavljenih rukopisa. [Serbian Folk Songs from Unpublished Manuscripts.] Vol. I. Beograd: SANU.

Karadžić, Vuk 1975. Srpske narodne pjesme. [Serbian Folk Songs.] Vol. I. Beograd: Nolit.

Karanović, Zoja 1990. Narodne pesme u Danici. [Folk Songs in Danica.] Novi Sad: Matica srpska; Beograd: Institut za književnost i umetnost.

Karanović, Zoja 1999. Narodne pesme u Matici. [Folk Songs in Matica.] Novi Sad: Matica srpska; Beograd: Institut za književnost i umetnost.

Karanović, Zoja 2010. Nebeska nevesta. [Celestial Bride.] Beograd: Društvo za srpski jezik i književnost Srbije.

Kovačević, Ivan 1985. Semiologija rituala. [Semiology of the Ritual.] Beograd: Prosveta.

Kuhač, Franjo Ksaver 1941. Južno-slovjenske narodne popievke. [South Slavic Folk Songs.] Vol. V. Zagreb: Tiskara i litografija C. Albrecht.

Lakoff, George \& Johnsen, Mark 2003 [1980]. Metaphors We Live By. London: The University of Chicago Press.

Lilek, Emilijan 1898. Ženidba i udadba u Bosni i Hercegovini. [Wedding in Bosnia and Hercegovina.] Glasnik Zemaljskog muzeja, Vol. 10, pp. 5-92.

Maltsev 1989 = Mal'tsev, Georgii. Traditsionnye formuly russkoi narodnoi neobriadovoi liriki. [Traditional Formulas of Russian Non-Ritual Folk Lyrics.] Leningrad: Nauka.

Miladinov, Dimitar \& Miladinov, Konstantin 1961. B"lgarski narodni pesmi. [Bulgarian Folk Songs.] Sofia: B"lgarski pisatel. 
Mršević Radević, Dragana 1996. Srpska frazeologija - jezički okvir za mitski sadržaj. [Serbian Phraseology - Linguistic Frame for Mythic Content.] In: T. Bekić (ed.) Mit. [Myth.] Novi Sad: Filozofski fakultet u Novom Sadu, pp. 395-404.

Nedić, Vladan 1977. Antologija narodnih lirskih pesama. [Anthology of Folk Lyric Songs.] Beograd: Srpska književna zadruga.

Nikolić, Grigorije 1888. Srpske narodne pesme. [Serbian Folk Songs.] Vol. I. Novi Sad: Srpska knjižara i štamparija Braće M. Popovića.

Osinin, Dimit'r \& Burin, Ivan 2006. B'lgarsko narodno tvorchestvo v dvanadeset toma. [Bulgarian Folklore in Twelve Volumes.] Vol. VI. Ljubovni pesni. [Love Songs.] Varna: LiterNet.

Petranović, Branko 1989 [1867]. Srpske narodne pjesme iz Bosne i Hercegovine. [Serbian Folk Songs from Bosnia and Herzegovina.] Vol. I. Sarajevo: Svjetlost.

Popović, Pavao 1888. Kraljice: Srpski narodni običaj o Trojčinu dne. [Queens: Serbian Folk Pentecost Costume.] Brastvo, Vol. 2, pp. 7-29.

Popović, Sreten 1950. Putovanje po Novoj Srbiji 1878/ 1880. [Journey through the New Serbia, 1878/1880.] Beograd: SKZ.

Radenković, Ljubinko 1986. Simbolika boja u narodnim bajanjima slovenskih naroda.

[The Symbolism of Colors in Slavic Folk Incantations.] Književna istorija, Vol. 19, No. 73-74, pp. 3-32.

Rajković, Đorđe 1869. Srpske narodne pesme (ženske). [Serbian Folk Songs (Women's).] Novi Sad: I. Fuks.

Rovinski, P.A. 1994. Crna Gora u prošlosti i sadašnjosti. [Montenegro in Its Past and Present.] Vol. III. Cetinje: Izdavački centar Cetinje / Centralna narodna biblioteka Đurđe Crnojević / Sremski Karlovci; Novi Sad: Izdavačka knjižarnica Zorana Stojanovića.

Said, Edward W. 1979 [1978]. Orientalism. New York: Random House.

Štrekelj, Karel 1904. Slovenski narodni pesni. [Slovenian Folk Songs.] Vol. III. Ljubljana: Slovenska matica.

Tolstoi, N. I. 1995. Vuchary. [Wolf Men.] In: I. N. Tolstoi (ed.) Slavianskie dreunosti: Etnolingvisticheskii slovar'. [Slavic Antiquities: Ethnolinguistic Dictionary.] Vol. 1. Moscow: Mezhdunarodnye otnosheniia, pp. 460-461.

Turner, Victor 1969. The Ritual Process: Structure and Anti-Structure. New Brunswick: Aldine Transaction.

Van Gennep, Arnold 1981 [1909]. Les Rites de Passage. Paris: Picard.

Veselinović, Jovan 1890. Lazarice, srpski narodni običaj u Vranju i vranjskom okrugu. [Lazarice, Serbian Folk Costume in Vranje and Vranje District.] Brastvo, No. 4, pp. 66-94.

Waldenfels, Bernhard 1997. Topographie des Fremden: Studien zur Phänomenologie des Fremden 1. Frankfurt am Main: Suhrkamp.

Waldenfels, Bernhard 2006. Grundmotiven einer Phänomenologie des Fremden. Frankfurt am Main: Suhrkamp.

Yastrebov 1886 = Iastrebov, Ivan. Obychai $i$ pesni turetskikh serbov. [Customs and Songs of the Turkish Serbs.] St. Petersburg: Tipografiia V.S. Balasheva. 
Zielinski, Boguslav 2006. O kategoriji svoj i tuđ u kolonijalnoj i postkolonijalnoj kritici. [On the Category of "Own" and "Foreign" in Colonial and Postcolonial Criticism.] In: M. Maticki (ed.) Svoj i tud: Slika drugog u balkanskim i srednjoevropskim knjižeunostima. [Own and Alien: The Image of the Other in Balkan and CentralEuropean Literatures.] Beograd: Institut za književnost i umetnost, pp. 55-60. 


\title{
FOLK MYSTIC: A NARRATIVE OF A POLISH HIGHLANDER CUNEGONDE SIWIEC
}

\author{
Tomasz Kalniuk \\ PhD, Department of Ethnology and Cultural Anthropology \\ Nicolaus Copernicus University in Torun, Poland \\ e-mail: tekantrop@umk.pl
}

\begin{abstract}
This article presents the figure of Cunegonde Siwiec, a folk mystic and a highlander, who lived in one of the villages in Lesser Poland at the end of the nineteenth and the first half of the twentieth centuries. Stryszawa is a linear village located in the Sucha County, an ethnographic region inhabited by the highlanders of Babia Góra. Kundusia - this is what she was called by people around her - became an inherent part of this area, at the same time being considered to be both one of the fellow countrywomen and an extraordinary neighbour. Making use of the available literature, I present in the text relations between Cunegonde and the place of her residence, and on the basis of the field research I show her impact on the environment. The structure of the text is made up of the following three parts: elements of the ethnography of the Babia Gora region, reconstructed fragments of Cunegonde's biography, and the narrative about Cunegonde circulating among the inhabitants of the village and pilgrims. ${ }^{1}$
\end{abstract}

Keywords: Cunegonde Siwiec, folk culture, highlander, mystic

\section{REGIONALITY}

Located in the Sucha County (with the administrative seat in Sucha Beskidzka), the village of Stryszawa along with a few other rural settlements constitutes a ten-kilometre-long linear village. It lies on the hill of Siwcówka and is a hamlet with several houses (only a few of which have their fixed all-year-round tenants). 'Years earlier, a clergyman who came to this area noted that Siwcówka itself lies as if in the centre of an amphitheatre of mountains' (Bartkowski 2008: 14). Its remoteness and the resulting territorial isolation (nowadays, in the era of commonly available cars, the isolation is only symbolic) bring up the association with the history of the area: in the ninth century the territory that belonged to Slavic Vistulans ${ }^{2}$ was an uninhabited forest-covered land (see Krzywda 2010: 14). Good knowledge of the terrain, location next to important communication routes, and a difficult financial situation of the local commu- 
nity seemed to be sufficient factors for people to become robbers. However, the scope of this phenomenon was neither big nor severely perceptible, because the highlanders who later became robbers handcrafted in more distant areas so as to be able to come back "to their own people" for winter. Irrespective of the extent of the phenomenon, the robber-related narrative repeated in the local folklore helped to reinforce the perception of a relationship between shepherds and robbers. This mode of thinking can be perfectly confirmed by a written note from the nineteenth century. Its content leaves no doubt as to the fact that any contact with people from Babia Góra hardly differed from the encounters with the wild. The author himself, Józef August Schultes, an Austrian botanist and a local historian, distastefully wrote the following words about the looks of the inhabitants at the foothill of Babia Góra: 'a cold, dead and addled face expression, because of which the imagination of an artist painter withers away' (as cited in Janicka-Krzywda 2010: 24).

Stryszawa gained a permanent reputation as an area of highland robbers. A powerful example of this is a contemporary crest of Stryszawa, which includes two curved knives. Etymology and history also point to poverty as a motivational factor to lawlessly commit robberies. The old Polish word strysz means either

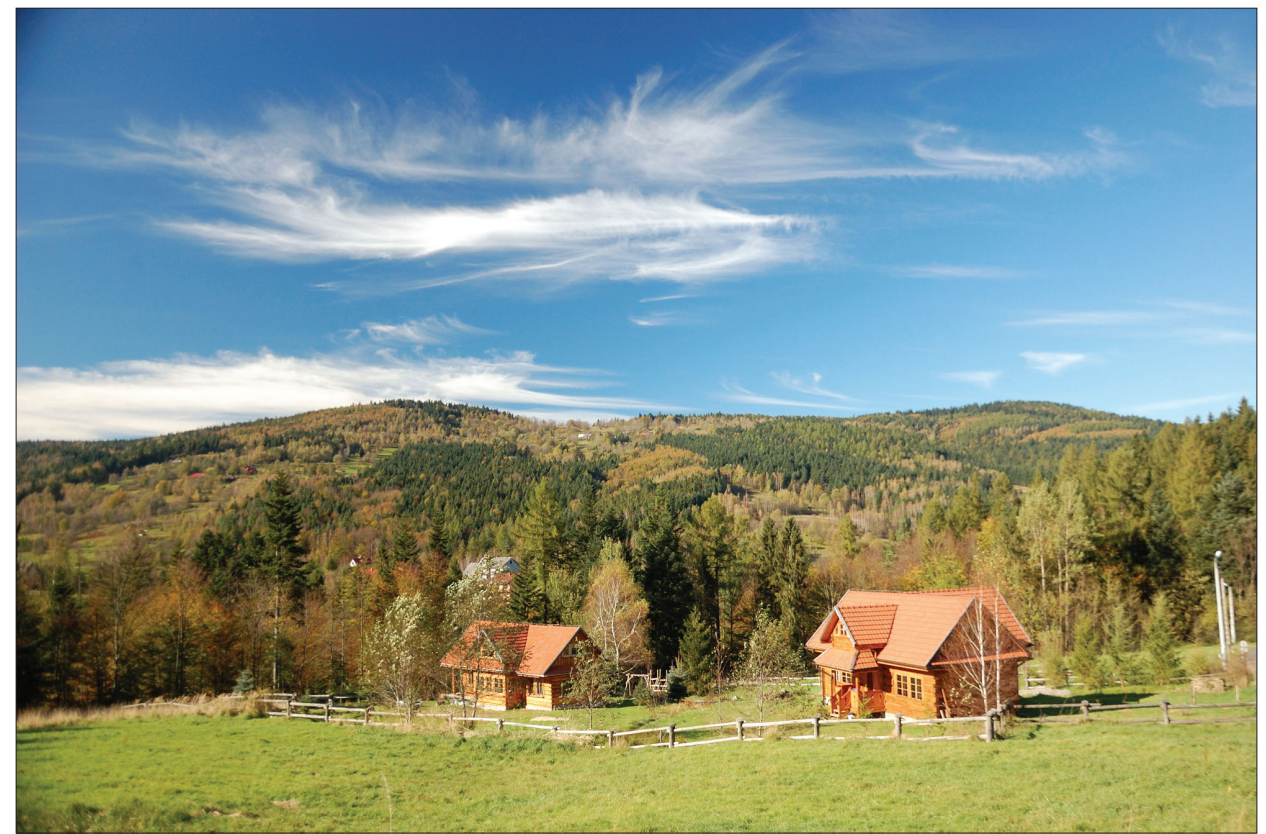

Figure 1. The present panorama of Siwcówka. Photograph by the author 2014. 
a poor settlement or a poor man. A narrative describing a well-known "Galician poverty" gives succour to the above explanation. The inhabitants of Babia Góra definitely needed to face poverty more often than robberies, and this resulted in their ability to develop resourcefulness. Apart from being involved in activities typical for mountainous areas, such as growing crops, breeding cattle, and shepherdry, people in Stryszawa also produced and processed wood. Because of the fact that after 1918 there was not enough farmwork for everyone, people looked for sources of income from handcrafting - cooperage and carpentry. A large number of inhabitants proved able to make wooden toys, which were subsequently sold at local fairs in Sucha Beskidzka, Cracow, or in the area of Silesia Province (Walczak 2002: 40). Nowadays, Stryszawa is an important centre for folk sculpture and toy-making. Apart from multi-coloured "birds of paradise" available to be bought at the Beskidian Centre of Wooden Toy, and the permanently repeated folklore narrative of robbers, Stryszawa is famous for an autochthonic mystic woman, Cunegonde Siwiec.

Figure 2. A contemporary wooden toy from Stryszawa. Photograph by the author 2014.

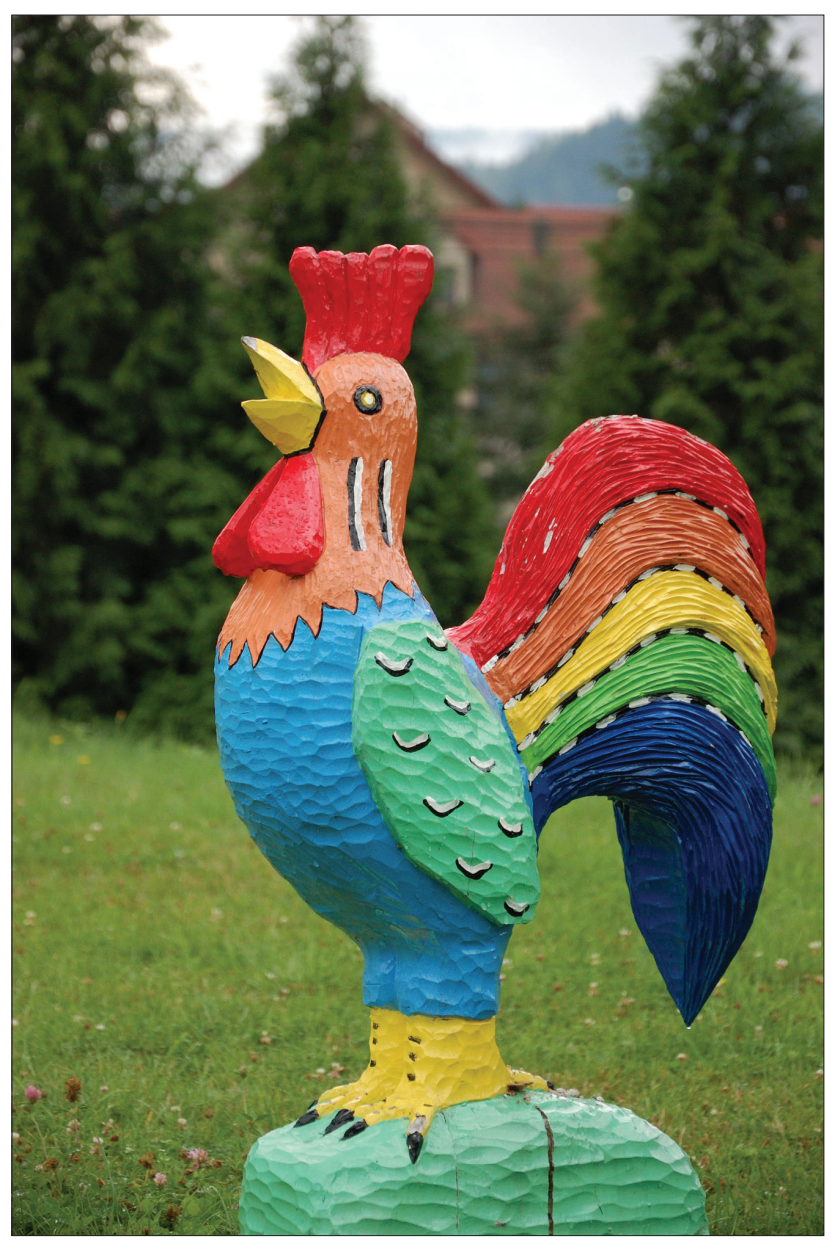




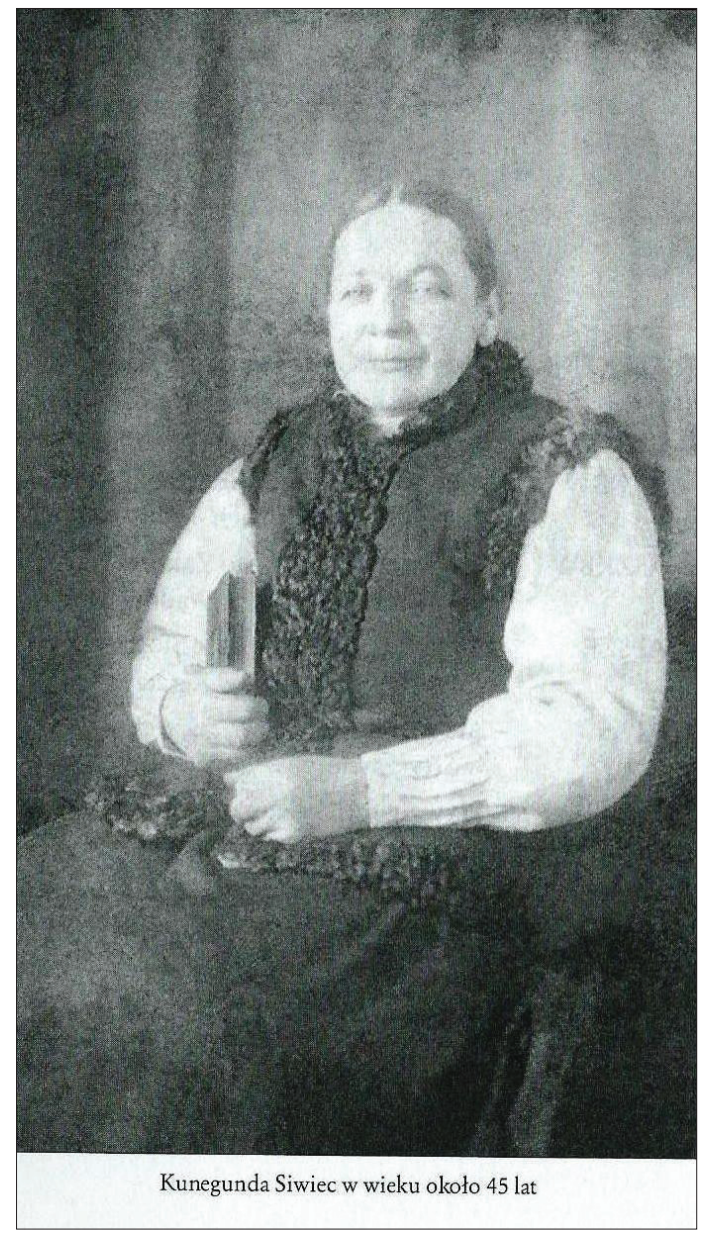

Figure 3. Cunegonde Siwiec at the age of around 45 years (Zieliński 2010: 10).

Her life and her message are organically connected with Siwcówka. The mystic lived and died in a secluded small settlement. She also caused a lasting change in the latter's structure. Siwcówka was converted from an ordinary hamlet into a local religious centre. A convent and a chapel were built there due to Cunegonde and her siblings' generosity. These religious buildings remain living memorials of the mystic and invest the settlement with religious significance. Only recently Cunegonde's mortal remains were taken from the churchyard and ceremonially placed in the chapel. The need for emphasising the place, while describing the highlander's mystic experiences, results from the status given to the place by God. In Cunegonde's mystic revelations God calls Siwcówka the place of His mercy and rest. He promises to remain present there even after Cunegonde's death. 


\section{PERSONALITY}

The idea of Cunegonde's spiritual self-portrait and its connection with the local space evokes the concept of folk religion. This literary term is used with reference to the village community's religious behaviour. Its members were strongly associated with their local natural environment because of living off the land. In the article, the folk religion does not mean pre-Christian beliefs (or their elements or relics; compare to Hukantaival 2013: 102), nor does it indicate a system different from the catholic one. The folk religion forms a specific current within its boundaries (similarly, folk culture is a part of national culture), known as folk piety. The folk piety results from a long-lasting interconnection between the official Roman Catholic Church doctrine and the specificity of the local milieu (Cameron 2010: 6). It is, for example, characterised by the attachment to communal forms of cult resulting in mass, emotional and ostentatious participation in liturgy and paraliturgical services as well as by sensuality that makes the form and the content of the cult equal.

Cunegonde grew up in the atmosphere of folk religiousness and so behaved accordingly (for example, as an illustration of sensuality, she rubbed a sick cow with the picture of St. Thérèse of Lisieux). At the same time, she went beyond the limits of folk piety, developing a personal relationship with God, which placed her in the field of mysticism. Cunegonde was a folk mystic coming from a rural background and living in a secluded settlement, but at the same time she stood out against her milieu because of her profound, individual, and personal relationship with the sacrum (Lat. holy bone). Although her attitude was characterised by subjectivity of her religious experience, it was still connected with her place of living and has resulted in a limited character of her cult, which is typical of folk religiousness. The folk mystic's attitudes are quite similar to the ideals of St. Thérèse from Lisieux (also called the Little Flower). The witnesses' opinions as well as the notes of Cunegonde's supernatural visions testify to both her reverence for the French saint and the practice of "the little way of spiritual childhood" discovered by Thérèse, which consists of simple faith and of trust in God's mercy. God, who spoke to Cunegonde, repeatedly called for taking towards Him the attitude of a little child.

The mysticism of Cunegonde, reduced to supernatural visions, was not known to people in her environment. However, her mysticism treated as an intense life of prayer did not raise anyone's doubts: 'People believed in her intercession' (Zieliński 2010: 107). Cunegonde's favourite saint, St. Thérèse of Lisieux, redefined the concept of mysticism by shifting the focus from ecstasies and visions towards volitional experience of the communion of a person with God (see Stinissen 2001: 88). Kundusia (this is what she used to be called and what 


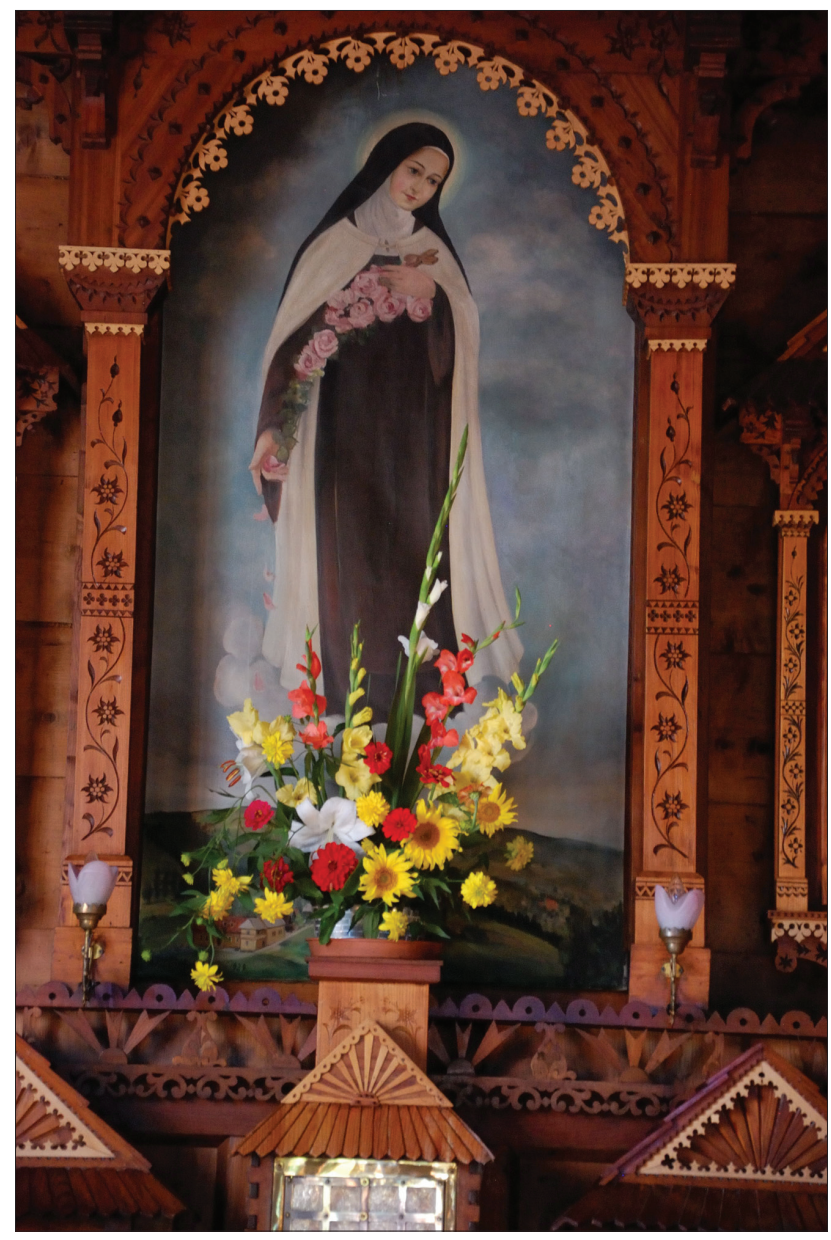

Figure 4. Chapel of St. Thérèse of the Child Jesus in convent. Photograph by the author 2014.

she is referred to also today) lived in unity with God, aware of His permanent presence. People who met her knew that she was different and they watched their female neighbour's long prayers, which was what distinguished her from others. The prayer created an invisible barrier separating her from the group, but at the same time it did not exclude her from the ongoing daily life.

Cunegonde Siwiec is a historical figure inscribed in the history of the land of Stryszawa. According to a record in the Parish Baptismal Register of Saint Anna's Church in Stryszawa, Cunegonde was born on 28 May 1876 as the tenth child of Jan and Wiktoria Siwiec. The biography of Cunegonde and her family is intertwined with the history of the region. Her grandparents were the founders of a new rural settlement, and her father owned a considerable amount of land and had a reputation of being a good landholder. Cunegonde 
gave a part of the inherited land to the benefit of the church and in this way the local space was permanently changed. In 1929 a convent of the Sisters of the Resurrection was built in Siwcówka. It had a Chapel of St. Thérèse of the Child Jesus, which was open for people. ${ }^{3}$ In the new place, nuns carried out educational and charitable activities as part of the operation of the Scientific and Educational Centre. Orphans from all over the country and young girls from the neighbourhood started to come to Siwcówka to be taught how to sew, embroider, and do farmwork. ${ }^{4}$ Cunegonde is present in the recollections from that period of time, which are recorded in the chronicles of the convent and in the collected private archives (see Donajska 2014: 42-62). The records highlight, above all, her unique piety that was expressed by the intensity of her prayer:

I remember-says Sister Lucjana Maryka - that sometimes she had prayed in the chapel for so long that her niece, Hanusia Leśniak, came there to take her out for fear of her health. When we saw that she had already stayed in the chapel for a few hours, we also sometimes invited her to come round for a meal. (Zieliński 2010: 88-89)

Not much time passed until the chapel was to become Cunegonde's second home. The home in which she was born and died did not stand out from the others. The house was a typical chimneyless hut and was equipped with a chimney some time later. In the same way, Cunegonde fitted in the ordinary life landscape of the people from Siwcówka. Together with the women from the settlement she fetched water from a stream, washed the undergarments, using wooden washing bats, and helped with farmwork. Taking part in the everyday life of the then Stryszawa, especially during World War I, involved coping with numerous adversities, such as requisition of goods for military use, hunger, and epidemics. In the settlement devoid of men $^{5}$, it was women who assumed the responsibility for maintaining houses and fields:

Long years of hard work and taking care of the family and the house left numerous traces on Cunegonde's body. They were on her shoulders, feet, and knees. Most of them were, however, on her hands. Hard, cracked skin on her hands was a living proof of everyday hardship. (Zieliński 2010: 41)

The rhythm of life at that time focused around the necessity to work, with breaks only for sleeping and some occasional holidays. The Siwiec family were considered to be decent, peaceful, and hardworking. There were several inns providing services to the inhabitants in the area of Stryszawa, but the Siwiec family did not use them. They lived in a profoundly religious atmosphere, which, according to what Władysław Orkan once wrote about highlanders, was not typical for the traditional folk culture. Orkan stated that generally the life of highlanders was 'permeated by religion to a small extent' (Orkan 1946: 125). 


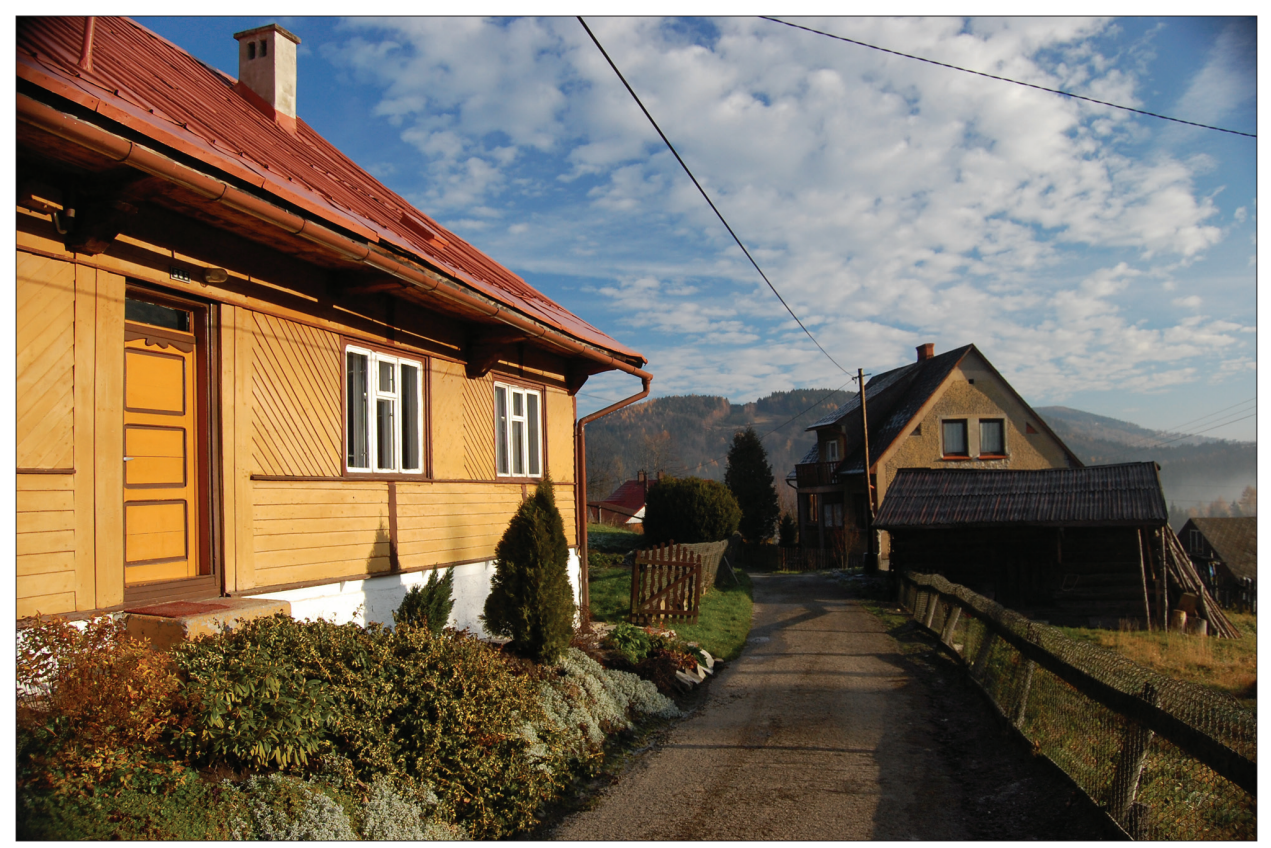

Figure 5. Cunegonde's wooden house. Photograph by the author 2012.

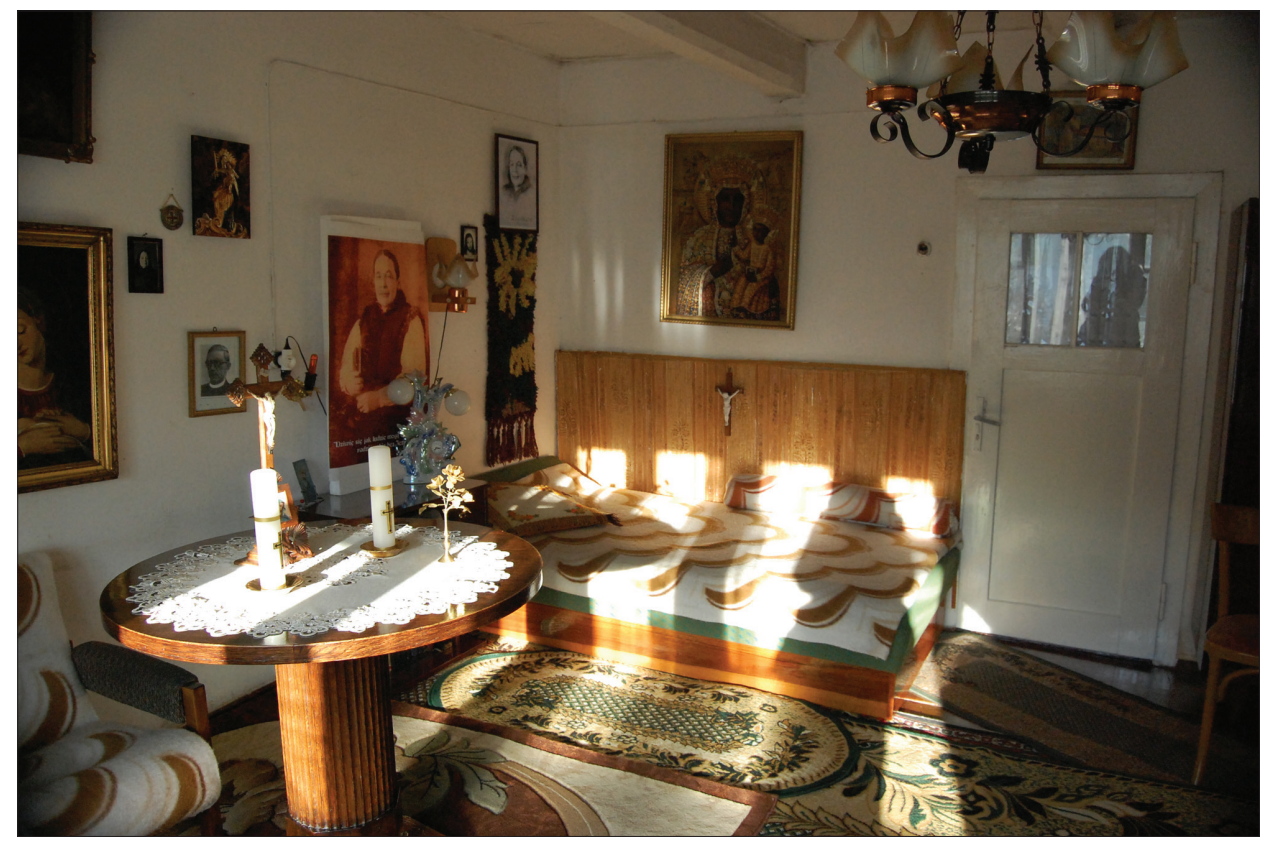

Figure 6. The interior of Cunegonde's house. Photograph by the author 2012. 
This opinion is in line with the statement of Ludwik Stomma, who observed, in his analysis of folk religiousness, that there was a low proportion of spiritual people in the rural areas in Poland (see Stomma 2002: 274). The Siwiec family belonged to a group of believers who showed more lively interest in the matters of the Church. They read plenty of newspapers and Catholic books, which was by no means a typical behaviour of people living in rural areas. It was usually Michał, Cunegonde's younger brother, who did the reading, while others listened and later shared their afterthoughts (Cunegonde and the majority of the family and neighbours were half illiterate). Among the books read at their house were some requiring careful and reflective recipients, for example, the works of Carmelite saints. The books were borrowed from the monastery library of the Carmelite Fathers in Wadowice. Contacts with monks and their spirituality soon resulted in Cunegonde's becoming a member of the secular branch of the Carmelite Order, where she was known as Sister Thérèse of the Child Jesus.

Undoubtedly, Cunegonde got her first religious education in her family home. ${ }^{6}$ The everyday atmosphere of Siwcówka also taught her higher values, 'because her faith in God, in His truths and laws was at the same time the basis of the whole philosophy of life and the standard of behaviour' (Bartkowski 2008: 16). The general faith in God's protection was common in the village and a large number of inhabitants participated in religious practices. But this was not enough for Cunegonde, that is why she took a private vow of chastity and, as a consequence, she remained unmarried. Such a choice gave rise to a concern since the traditional approach to life focused on increasing the value of family business. According to William Thomas and Florian Znaniecki, one of the constitutive features of the rural community was marriage, while spinsterhood and bachelordom resulted in the alienation of an individual (Thomas \& Znaniecki 1976 [1918]: 110-124). In the case of Cunegonde, the decisive factor for choosing a solitary life was not her unfavourable fate but an exceptionally strong spiritual experience. The decision to remain single in order to lead a more devoted religious life was probably made at the age of twenty. Father Bernard Łubieński, a well-known retreat preacher, conducted popular missions in Stryszawa at that time. 'Such Kundusia came back from these missions and such she will remain for the rest of her life,' wrote her spiritual director (Bartkowski 2008: 17).

The inhabitants of Siwcówka accepted Cunegonde's unusual choice and, what is more, treated her with respect. She gave advice to people, some of whom came to her voluntarily and some through referral by a priest. The number of people seeking advice increased especially after Cunegonde had completed appropriate courses to become a lay catechist, the so-called sidziniarka ${ }^{7}$. Women who belonged to this movement were respected mainly because of the fact that 
they had made their personal vow of virginity and were well informed in local realities. 'They knew well what a highlander's soul is like, so their impact on the highlanders who were "puffed up", distanced from the Church or in conflict with one another was sometimes more effective than that of their parish priest' (Zieliński 2010: 56). Pious women and also tough introverted men asked Cunegonde to help them prepare for the confession. She had courage to tell them the truth and maintain respect at the same time. Cunegonde's sincerity and kindliness won her the ear of the inhabitants of Babia Góra, but obviously only of those who wanted to listen to her, because there was also a group of mockers who were distrustful of her piety. 'There was a rumour around that she talked to Lord Jesus. Some laughed at it, others wondered,' recalls Wiktoria Janik (Zieliński 2010: 94).

In Cunegonde's lifetime, her extraordinary experiences were known only by her household members and the nuns with whom she maintained closer contact. Father Bronisław Bartkowski, Cunegonde's confessor, soon joined the circle of people who were aware of her case. The priest had been listening to her confessions for many years and he knew that Cunegonde was a spiritually mature and emotionally balanced person. An unexpected confession about the voices she had been hearing, persons she had been seeing, and conversations she had been holding disturbed the priest's current image of the penitent. Although he ruled out hallucinations and did not suspect a lie, he was far from being uncritical and decided to investigate the whole matter. A sign that confirmed the authenticity of the visions was a confession made by one of Siwcówka inhabitants, who had avoided confessionals for years. Not disclosing the details (the idea was that he wanted to hear a confession of a certain person on a certain day), Father Bronisław told Cunegonde to pray. In due time, he was given a positive answer.

The third day of May [of 1943] arrived. After the devotion I sat in a confessional and who should I see next to the confessional but this sinner? People started to slowly leave the chapel and then the man stood up and instead of heading for the exit, he stepped up to the confessional.

(Bartkowski 2008: 30)

This situation combined with the direct observation of Cunegonde's life made Father Bartkowski confirm his conviction that her life experiences were of supernatural nature. It must be added that he could clearly distinguish her piety from unhealthy devotionalism: 'There was nothing hothouse, nothing bookish, nothing for show,' he wrote (Bartkowski 2008: 20-21). The priest provided Cunegonde with spiritual assistance until her death on 27 June 1955. During this time, he observed the spiritual growth of the penitent, whose increasingly clearer mission was to pray for sinners and co-suffer with Christ. After a period of intense verbal apostolate, Cunegonde embarked on a path towards expia- 
tion: 'Over the years there were fewer and fewer opportunities to talk about God. On the other hand, situations involving spiritual or physical suffering began to mushroom on her way' (Zieliński 2010: 101). First, she lost sight in her right eye as a result of trachoma ${ }^{8}$. Then, more and more frequent pains in her limbs revealed bone cancer, which had made it completely impossible for her to leave home since 1948. In his recollections related to that period of time, Father Bartkowski compares the bed in which Cunegonde had lain for seven years to the wood of the cross on which Jesus had suffered. Because of devastating pain, Cunegonde was not able to turn over or sleep and in spite of the fact that she was always brave and patient, 'she could not refrain from screaming' (Bartkowski 2008: 22). The priest confessed that the suffering did not deprive her of serenity:

There was constant peace and a bright smile on her face except when she suffered severe pains. And although it would seem that she needed much comfort herself, it was her who gave comfort with all her ardent heart to those who came to her with their small and big worries. (Bartkowski 2008: 23)

Cunegonde's descriptions written down by the priest constitute the testimony of her supernatural experiences. The highlander did not know that the notes taken down by her confessor would ever be made public. On the other hand, Father Bartkowski did not strive to promulgate the materials although he was aware that writing down Cunegonde's inner experiences was valuable for spiritual formation (see Zieliński 2010: 93). As a consequence, for many years the text had been shared among only a handful of people, especially the Sisters of the Resurrection (Donajska 2014: 59). The publication of the notes ${ }^{9}$ attracted keen interest both among the clergy and lay people, who in 1996 initiated the efforts to raise Cunegonde to the honours of the altar. Along with the preliminary works undertaken by Polish canonists, the Friends Association for Cunegonde Siwiec was founded in 1998. Its members organise annual pilgrimages to her tomb in Stryszawa, which fall on the day of the feast of Our Lady of Perpetual Help. Moreover, in cooperation with the Carmelite Order, they try to explore and promulgate the spirituality of the highlander woman. An example of this was, among others, a scientific conference devoted to various aspects of her spiritual path, held in 2006 in the Carmelite Spirituality Institute in Cracow. On 21 December 2007, the Metropolitan of Cracow, Cardinal Stanisław Dziwisz, officially opened the beatification process (see Zieliński 2010: 116). However, according to Ewa Leśniewska, 'on Friday, 28 October 2011, there was the closing of the diocesan investigation into life, virtues, and opinions on the sainthood of the Servant of God, Cunegonde Siwiec, of the Secular Order of the Discalced Carmelites, who died in 1955 in Stryszawa, near Sucha Beskidzka, in the Archdiocese of Cracow' (Leśniewska 2011). 


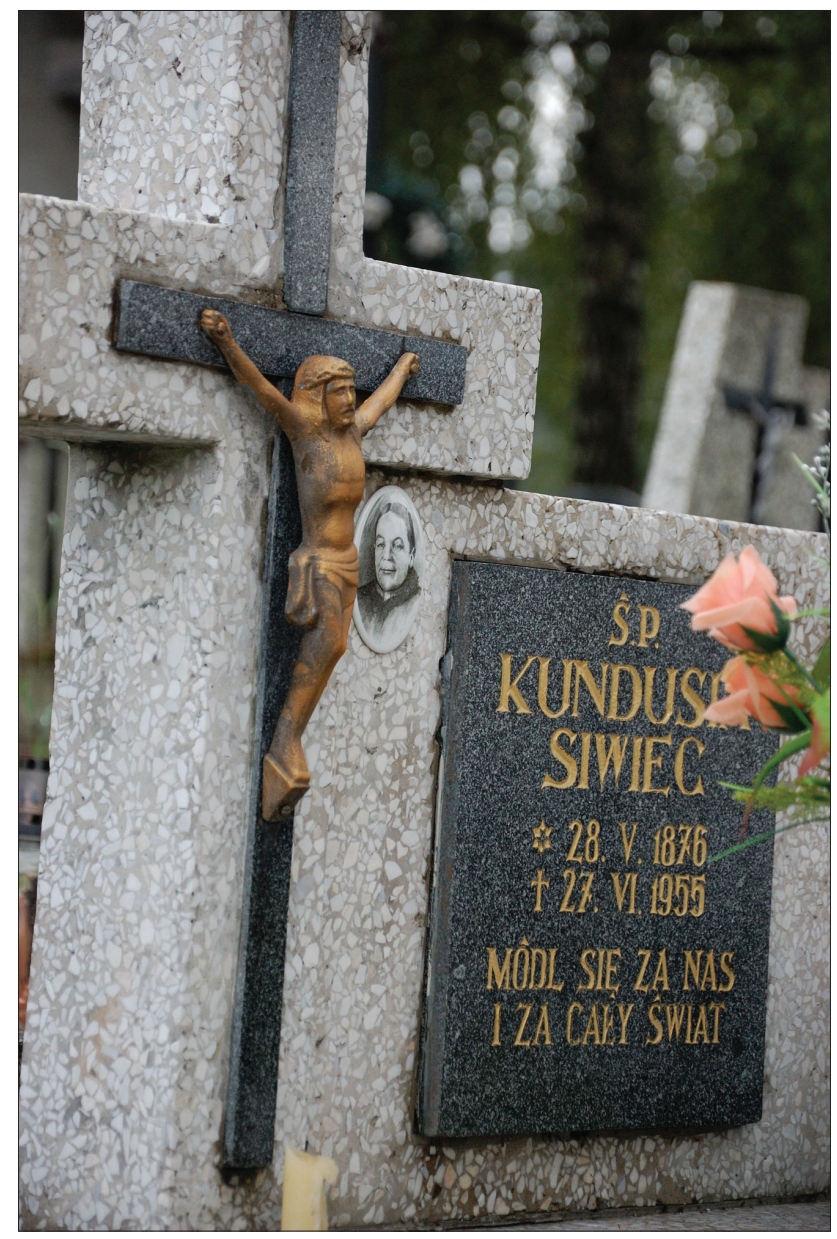

Figure 7. Cunegonde's tomb near the church of Saint Anna in Stryszawa. Photograph by the author 2014

In the Catholic religious observances, reverence of saints who are not accepted by the Church authority is rather rare, and any such occurrences are not longlasting. The required standards in this respect distinguish Catholicism from the Orthodox Church and from some sects where there may be a grassroots veneration of saints. As a result, Cunegonde's case would not spread among believers unless it was approved by the clergy. Roy Rappaport claims that the confirmation of sainthood consists of a few elements: apart from the faith factor and using the Ultimate Sacred Postulates, the believers' involvement in liturgy is crucial (Rappaport 1999: 288, 396). The case discussed in the article first requires the church authorities' consent. As a result, both the dynamism of the faith and the extent of the folk mystic's cult are connected with the progress of the church committee's work. At this point in time, as since 2007 there has been a beatification process in progress in Rome, a certified miracle 
is required. Without it, the religious veneration will remain only at the current, local level. The recent events show that some development is to be expected. In November 2016, Cunegonde's mortal remains were exhumed, then put into an ornamented sarcophagus, taken from the parish churchyard and placed in the chapel in Siwcówka. The procedure involved preparing bones to be made into relics when the beatification takes place (see Exhumation).

\section{INFLUENCE}

The content of Cunegonde's dialogues with Jesus, Mary, and other saints is consistent with the so-called 'little way of spiritual childhood', which was initiated by a French saint, Thérèse of Lisieux. Its novelty comes down to exercising, in one's religious life, the attitude of a small child towards God. Feeling incapable of practising a higher level of asceticism, St. Thérèse stuck to the Gospel incentive to remain small, and elaborated on the thought of the necessity to completely trust in God: 'For this [she wrote about gaining sanctity] I do not need to grow. On the contrary, I need to remain small and become even smaller' (Stinissen 2001: 96). Lord Jesus replied to Cunegonde's concerns that 'weaknesses disappear in His love like sparks in the air, and what He really wants is just to reciprocate love: Like a child who does not think about anything else but loving their parents, and the father thinks about the child's needs, so you do as if nothing else existed in the world but Me and you' (Bartkowski 2008: 212). Cunegonde's conversations with Christ and saints relate to the aspect of trusting in God's mercy, which was the basis of Little Thérèse's spirituality. Thérèse herself during a supernatural vision told the highlander the following words: 'Even whipping and penance will not equal childlike love. God is leading you through the path of childlike trust' (Bartkowski 2008: 208). This was confirmed by Jesus when in one of the dialogues he told Cunegonde: 'Go through the path which was chosen by me and which was recently started by my bride Thérèse. This path of love pleases me most' (Bartkowski 2008: 60). Similar to the French saint, for whom the act of dedication to the merciful love was a breakthrough (Stinissen 2001: 89), Cunegonde also made her life an uninterrupted act of love. She gave herself entirely to God, who was suffering from human anger and ingratitude, so as in this way to become the vessel for His mercy:

My daughter, I love those who love me and I wish to be loved with clean, immaculate and sacrificial love. I exalt such souls above the whole world and on these souls I pour my love, which others despise. Indeed, I pour on these souls my great love and even greater love, because these souls please 
me and disarm my justice aimed against sinners. Through these souls I pour my mercy on the whole mankind. (Bartkowski 2008: 192)

In Poland, the meaning of the Divine Mercy became more important owing to holy sister Faustina Kowalska, who lived in the times of and near Cunegonde in Łagiewniki district in Cracow. An ordinary nun of the 'second choir' (see Czaczkowska 2012: 124) was explicitly called by God 'the secretary of His mercy' (see Kowalska 2010 [1981]: 430). As in the case of Thérèse and Cunegonde, Jesus assured her that 'love fills up the abyss that exists between His greatness and her nothingness' (Kowalska 2010 [1981]: 175). Struck by the profound awareness of God's goodness on the one hand and human sin on the other, Faustina encouraged everyone to trust in the Divine Mercy. In one of her meditations, she said to Jesus: 'I doubt that You will pardon my numerous sins; my misery fills me with fright' (Kowalska 2010 [1981]: 396). In response to this, she heard a voice: 'My mercy is greater than your sins and those of the entire world' (Kowalska 2010 [1981]: 396). Having experienced numerous hardships, the nun made a confession to God:

I fly to Your mercy, Compassionate God, who alone are good. Although my misery is great, and my offences are many, I trust in Your mercy, because You are the God of mercy; and from time immemorial, it has never been heard of, nor do heaven or earth remember, that a soul trusting in Your mercy has been disappointed. (Kowalska 2010 [1981]: 460)

Apart from obvious theological similarities, the revelation of the mystery of the Divine Mercy to St. Thérèse of Lisieux, Cunegonde Siwiec, and Faustina Kowalska contains an analogy in the promise of its continuation. In her last months of life, which she spent suffering from tuberculosis in the infirmary, Thérèse stated that her heaven would be to do good on earth: 'I cannot let myself rejoice, I do not want to rest until there are souls to be saved' (Agnes of Jesus 2014: 107). Sister Faustina wrote in her Diary: 'I feel certain that my mission will not come to an end upon my death, but will begin' (Kowalska 2010 [1981]: 113). To Cunegonde, on the other hand, God announced that when she goes to heaven to His Father's land, He will stay in her father's land, in Siwcówka: "This is the place where I will rest and from here I will spread my mercy across the whole world through my chosen ones, and I will confirm my mercy even with miracles' (Bartkowski 2008: 44, 216).

This correspondence of fates and thoughts was noted by pilgrims as well as by theologians, who stated that in the case of Cunegonde Siwiec we can notice an interesting symbiosis (see Zieliński 2010: 116).

As one reads the revelations of Kundusia, they can find lots of expressions which are identical or nearly identical to the "Diary" of Saint Faustina 
and the same profound simplicity: "talk to me", "beg, love", etc. Lots of thoughts expressed literally using the same method. (a 52-year-old woman from Wrocław)

As the chaplain of the Sisters of the Resurrection admits himself, in the beginning he perceived this similarity negatively:

As soon as I came here, I plunged into the notes of "The place of my mercy and rest", I looked for something original in those revelations, but I did not find anything. All revelations of that kind, conversations with Lord Jesus are similar to one another, that is why I was slightly disappointed, but what new things should I look for? (a 68-year-old man from Stryszawa)

Marcin Jakimowicz wrote in the Gość Niedzielny: 'We will not find here any sensation or a ready script for the "Beyond Belief" TV programme. It is a dialogue between a lonely woman and a human-deserted God' (Jakimowicz 2009).

A few literary and film works dedicated to Cunegonde's life have been made, which are available today. The fall of the communist system in Poland in 1989 brought socio-political, economic as well as religious freedom. The availability of the press and literature, including catholic media, has been enhanced due to the freedom of expression and religion guaranteed by democracy. (More about the changes in Polish Catholicism after the fall of communism, see in Borowik 2003.) The first diary of Cunegonde's visions was published in the early 1990s. In Poland, in post-communist times, when the public, political and economic life became subject to pluralism, also the religious sphere began to demonstrate some variety. The status of the Catholic Church changed. Although still dominating, it became one of many religious institutions, so Catholics became more selective (Bruce 2013 [2011]: 13; Parsons 1960: 304). Believers started to be exposed not only to one pervading value system but to many of them. Polycentrism and diversity in the modern type of society influenced the area of religiosity (Riis \& Woodhead 2012 [2010]: 174). Within the Polish postcommunist religiousness, 'the mystic from the mountains' found her followers in the Catholics interested in the message concerning 'the little way'. Thus, Cunegonde's spirituality, or rather her 'spiritual childhood' gains recognition not so much among mass audiences, but rather among specific groups of Catholics. Gradually, Cunegonde's case has become an object of interest for clerical and lay people from outside Siwcówka and Stryszawa.

There is a polarisation of attitudes towards Cunegonde among local people, ranging from personal devotion to whispered criticism. It is an example of otherness manifesting itself, as pointed out in numerous studies, in a bipolar fashion: tremendum et fascinans (Otto 1958: 41-49; Caillois 2001: 48). 
People from here have their own opinion of Kundusia, sometimes very critical, because for them she was as any other woman; they did not know she had conversations with Jesus, as these were very intimate matters. Apart from that, she was slightly original because of the fact that she decided not to get married. (a 68-year-old man from Stryszawa)

Helena Stańczyk, who in 1987 was the first to be captivated by Cunegonde's spirituality and took up collecting information about her from people, firmly rejects the veracity of negative opinions:

Those who had a negative opinion of Kundusia did not want to talk to me at all, or when I asked them to tell me the whole story, for example, one about a female servant to whom the Siwiec family allegedly did not pay and she escaped through a window, they did not want to tell me that and, especially when I demanded their signature, they would not agree. If a person did not want to sign, then for me it was just gossips which I did not listen to. (an 84-year-old woman from Jelenia Góra)

For the majority of people who remembered Cunegonde, she was a pious and good grandmother, who did not differ from others in terms of appearance:

There were lots of Kundusias there, lots of such old women wandered around, but this one was kind of a real one, she went to church in Siwcówka. I was about fifteen years old at that time, so I did not waste my time on old crippled women. Nothing marked her out then but the fact that she was a spinster and had a large plot of land, fields, and forests; now it belongs to the sisters. (an 80-year-old man from Stryszawa)

A woman from the neighbourhood states:

She was so, so.... kind-hearted. Even her close relative says that kids would go under her window and sing such naughty songs, and Kundusia would give them a candy. She was so warm to interact with; you could talk to her like to a good granny. (a 74-year-old woman from Stryszawa)

Another respondent says: 'Personally, I cannot say a bad word about Kundusia, as she was a good woman; she prayed in such a way that probably no nun here can pray like her' (an 82-year-old woman from Stryszawa). On the basis of the heard narrative, the chaplain extends Cunegonde's piety to the whole house: 'The Siwiec family, as I was told, were all very pious, especially Kundusia's brother, Michał' (a 68-year-old man from Stryszawa).

Negative opinions mainly relate to the fact that Cunegonde donated a plot of land to the benefit of the convent. 
Because people here are so land-oriented and don't understand how it is possible to give away the land to someone outside the family. ${ }^{10}$ Did they finally understand that there is nobody to manage the land and the fields are vacant? Don't I know about it? (an 88-year-old woman from Stryszawa)

People, even so closely related, said that they [the Siwiec family] were not good. But they wouldn't say why. There was a very poor family and the father was a heavy drunkard and would constantly come to them to fetch something. The Siwiec family did not want him to drink so much and take things out of their house, because it was not fair. How much longer was it to go on? And when he borrowed something, it was for keeps. People still say that in the place where the convent is, it is not Kundusia's patrimony, but her neighbours'. (a 74-year-old woman from Stryszawa)

A man from the lower village of Roztoki states: 'Nobody knows anything about Kundusia there and will say no good word of her. Why? You had to work there, she was alone, had a lot of land and needed help, but where did the money come from?' (an 80-year-old man from Stryszawa). One of the women speaks out about it, considering the sphere of sacrum and the perspective of spiritual combat:

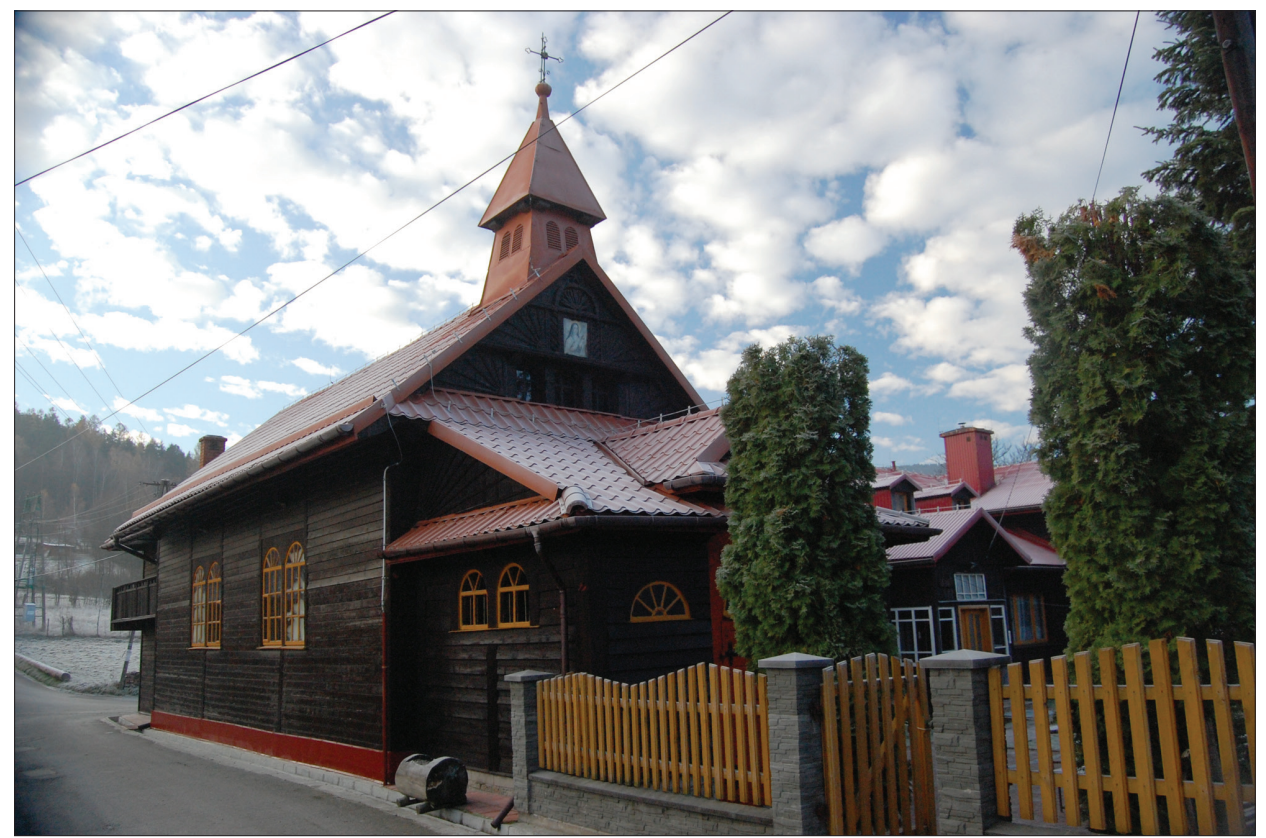

Figure 8. The local convent of the Sisters of the Resurrection in Stryszawa. Photograph by the author 2012. 
Where there is the good and the sacred, there are always lots of evil spirits around. People in the village were jealous of them [the Siwiec family], because they had everything. There were lots of them in the house and they grew wheat and potatoes, and Kundusia's brother Michatek was a great cooper, so they had money from that. (an 82-year-old woman from Stryszawa)

A change in the social structure of the village, a generational change, and progress in the beatification process of the Servant of God Cunegonde Siwiec result in the prevalence of positive opinions: 'People didn't know Kundusia and now it is changing because of books' (a 74-year-old woman from Stryszawa).

Now people's attitude is to think that there was something going on here. When there are natural disasters around, like storms or fires, and nothing happens here in Siwcówka, even local people who remember Kundusia say that it is because of her taking care. (a 59-year-old woman from Stryszawa)

A woman taking care of Cunegonde's house sees it in a similar way:

It happens now that when I sometimes meet somebody and ask them where they're from, they say that they're from Stryszawa, which was extremely rare before, because Stryszawa was not fond of her. (an 88-year-old woman from Stryszawa)

A village lost in the mountains with an inglorious past due to robbers and the village's small settlement isolated more than any other, located on the former Austrian-German border, cumulates various and sometimes contradictory threads of description. When phenomenologists write about otherness, they underline its relational character, which can be compared to a knot (see Waldenfels 2002: 70). Siwcówka demonstrates this duality, which is indicated by the results of research cited in this article. One can observe that the answers of the respondents contain the transformation of impressions and of the settlement's image:

For me, the whole Stryszawa was a backwater with old wooden houses; then I took it as great poverty. I was afraid when I was to come here years later, because I had this image encoded in my mind. Once I came back here, I saw a different world and met different, civilised people living in nice houses. I also perceived the convent differently; in those times it seemed so obscure, old and mysterious. And the mystery that I discovered was Kundusia, her contribution, her idea. Everything became close to my heart and at once I found my feet; I felt as if I had always been here. (a 59-year-old woman from Stryszawa) 
Enchanted by the history of Siwcówka and newly acquainted with the narrative of the folk mystic, pilgrims claim that 'this place is amazing and, above all, one can feel that it is a place of prayer' (a 52-year-old woman from Wrocław). A woman from Cracow, who has regularly visited this place for forty years, and a 72-year-old man living for several years in Ruda Ślacska, Silesia Province, who thinks that being in Siwcówka is 'like being in a fairy tale', unknowingly confirm the opinion of the chaplain (a 68-year-old man from Stryszawa), who has made a claim that "this area is a kind of "genius loci", in many ways related to various religious events from the past and today'. Mother Superior of the Sisters of the Resurrection also notices that Siwcówka is unusual. She remembers that initially her focus was placed on a historical wooden chapel dedicated to St. Thérèse of the Child Jesus: 'The chapel, which seemed so full of spirit and prayer, was a strong asset. This asset was the awareness of the fact that Cardinal Wyszyński and Cardinal Wojtyła prayed in this chapel' (a 59-year-old woman from Stryszawa). Over time, the amazement expanded, covering the following elements:

Kundusia, our Mothers Foundresses, John Paul II and Cardinal Stefan Wyszyński make up the whole environment, in which I feel good. The fact that here in Siwcówka there have been so many important people must be some God's plan. (a 59-year-old woman from Stryszawa)

How to explain this spiritual richness?

If you take, even in Poland, some places of revelations, it turns out that they are all on hills regardless of whether the place is a village or a city. Take Saint Faustina - the first revelation of Jesus took place in Płock, a city located on a hill, and here too is a hill, silence, seclusion. I have already been wondering about this a few times, because it is something of essence. Lord Jesus went uphill to pray. All important events in the life of Jesus, and contemporary events too, take place uphill, in private. Being uphill is like being closer to God. You could look at it from different perspectives, but we also have to take into account the fact that indigent God-reliant people are closest to Him. As you can read or hear from different sources, Kundusia's family could be wealthy, but they could share with others, helped the priest reach priesthood - they paid for him with the money they got from selling milk, cheese or eggs. ${ }^{11}$ When the sisters came, they looked after the girls who didn't have anything, as then it was Kundusia's family that provided everything. This family left everything behind. They were poor, closer to God. We must also analyse it from this point of view. Anyway, this was a god-fearing family; if one could read, then they read to everybody the Bible, the works of Saint Thérèse and John of the Cross. And 
what does John of the Cross say but: "nothing, nothing, nothing", nothing for oneself, nothing for the mind, just emptying of oneself. (a 59-year-old woman from Stryszawa)

As concerns the analysis of the ideas about the universe, anthropological studies prove that natural topography with distinctive points often gave rise to carrying out religion-tinted evaluations of space. Mountains dominating in the natural landscape gained a strong symbolic meaning. They were a popular motif in mythologies of different cultures and constituted a part of their vision of history. Universalist and traditional religions underline the spiritual functions of mountains and caves (see Eliade 1997 [1988]: 14-21). Contradictions present in a mountainous landscape facilitate thinking oriented towards the other and towards the sacred, which is often described as ambiguous (see Benedyktowicz 2000: 134; Bornemark \& Ruin 2012). Ambivalent concepts and feelings related to the perception of mountains, their horror and beauty, are parallel to the narrative about the creatures living in the mountains, such as gods, demons, and saints. The presence of the latter in human-unfriendly places, which were considered to be evil-haunted, resulted in the sanctification of such places (see Adamowski 1999: 133-136). In this context, the example of Cunegonde Siwiec is very meaningful. The god-fearing highlander from Siwcówka was famous for, among other things, her beneficial influence on the surroundings. The witnesses remember that one of her abilities was to tame the fiery nature of the inhabitants and pacify frequent arguments. Some people from Siwcówka believe that Cunegonde protects this area. The chapel located on the outskirts of Siwcówka reminds them of the prayers of their extraordinary neighbour, who miraculously saved them from the German occupants. ${ }^{12}$ 'Is a miracle going to happen?' I was asked by one of the inhabitants who anticipated my interest in the folk mystic. It is because the manifestation of a miracle will be decisive for further proceedings in the beatification process of the Servant of God.

\section{ACKNOWLEDGEMENTS}

The research was part of a grant for young scientists titled "Genesis and development of new places of religious cult in contemporary Poland based on the example of Stryszawa village (Sucha County, Lesser Poland Province)", carried out at the Department of Ethnology and Anthropology of Culture of the Nicolaus Copernicus University in 2014. 
Figure 9. The Chapel of the Heart of Jesus on the outskirts of Siwcówka. Photograph by the author 2014.

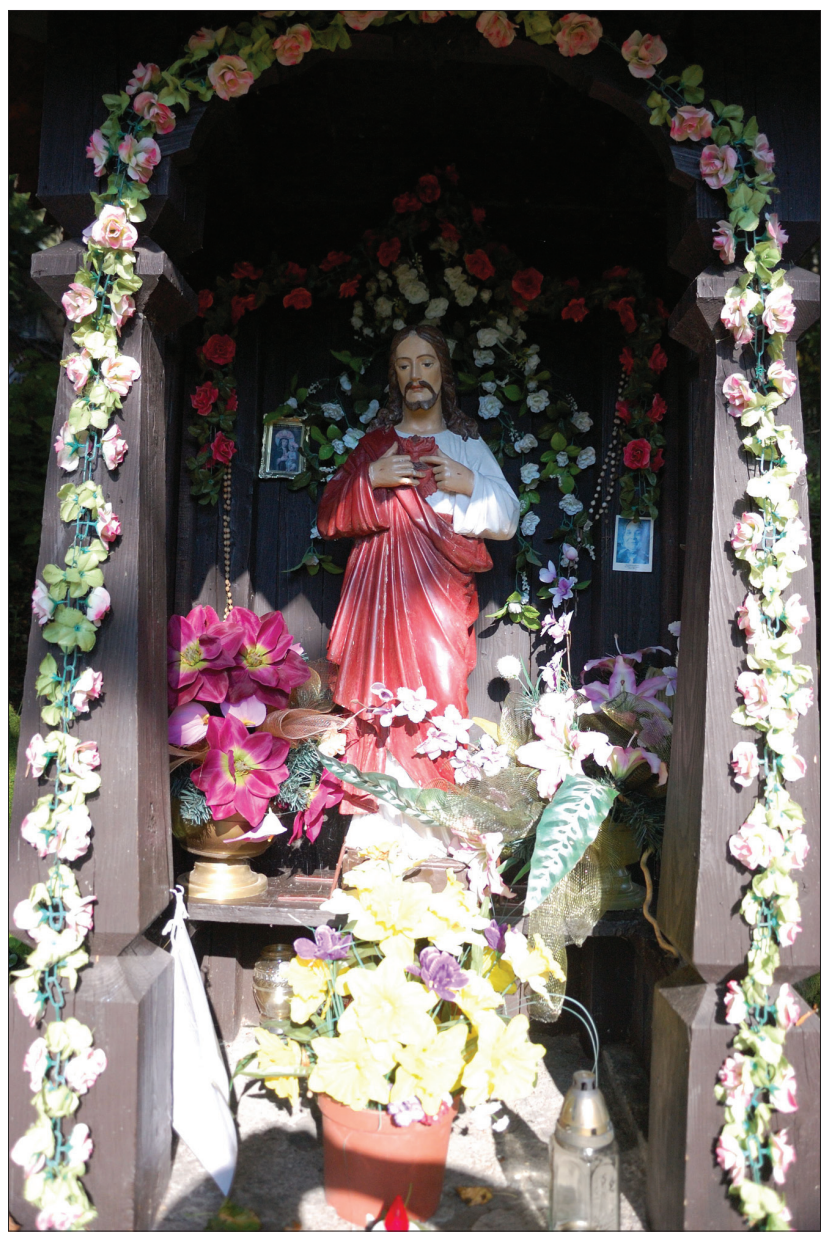

\section{NOTES}

1 This is a revised version of an article published in Polish in the Polish journal Literatura Ludowa in 2015 (Vol. 2, pp. 53-64).

2 A medieval west-Slavic tribe in Lesser Poland.

${ }^{3}$ Cunegonde had a dream, in which Saint Thérèse was dropping rose petals from the sky onto the neighbourhood. Adam Malicki, a painter from Warsaw, made a painting for the chapel on the basis of that dream (see Zieliński 2010: 85).

4 The long-term work of the nuns was definitely ceased by the decision of the authorities of the Polish People's Republic (PRL) in 1961 (see Walczak 2002: 121). 
5 They were forcefully recruited to the Austrian Army, in which the military service lasted from eight to fourteen years.

6 Once again this fact contradicts the statement made by Władysław Orkan, who wrote about highlanders that 'a house in a village is not where you get education' (see Orkan 1946: 130).

7 A colloquial name for women gathered around Father Wojciech Blaszczyński, a parish priest from Sidzina, who helped her with pastoral duties among people.

8 Bacterial inflammation of the conjunctiva and cornea.

9 The first book was published in 1995.

${ }^{10}$ Plenty of descriptions of folk cultures mention respect for the cultivated land as an important feature of a culture. An individual in rural areas was 'agri-centric', while the ownership of land was a decisive factor when it comes to a landlord's status (see Baniowska 2003: 127).

${ }^{11}$ It was Cunegonde’s friend, Father Józef Czarnecki (1894-1949).

${ }^{12}$ When the whole village was in danger during World War II, a miracle happened owing to Cunegonde's prayer. The bridge, across which the German soldiers were driving, suddenly collapsed and they had to turn back.

\section{REFERENCES}

Adamowski, Jan 1999. Kategoria przestrzeni $w$ folklorze: Studium etnolingwistyczne. [The Category of Space in Folklore: An Ethnolinguistic Study.] Lublin: UMCS.

Agnes of Jesus 2014 = św. Teresa od Dzieciątka Jezus. Żótty zeszyt. Ostatnie rozmowy św. Teresy od Dzieciątka Jezus zebrane przez matkę Agnieszkę od Jezusa. [The Yellow Notebook. St. Thérèse of Child Jesus: Last Conversations Collected by Mother Agnes of Jesus.] Warszawa: Pax.

Baniowska, Ewa 2003. "Chłopski świat” w świetle ksiąg sądowych wiejskich. ['A Peasant's World' in the Light of Village Court Books.] In: J. Kowalska \& S. Szynkiewicz \& R. Tomicki (eds.) Czas zmiany, czas trwania: Studia etnologiczne. [Time of Change, Time of Endurance: Ethnological Studies.] Warszawa: IAiE PAN, pp. 117-132.

Bartkowski, Bronisław 2008. Miejsce mojego miłosierdzia i odpoczynku: Nadprzyrodzone oświecenia Kunegundy Siwiec ze Stryszawy zanotowane przez księdza Bronistawa Bartkowskiego. [The Place of My Mercy and Rest: Supernatural Enlightenments of Cunegonde Siwiec from Stryszawa, Noted by Father Bronisław Bartkowski.] Cracow: Wydawnictwo Karmelitów Bosych. Available at https://www.kundusia. pl/sites/default/files/MMMiO.pdf, last accessed on 12 October 2018.

Benedyktowicz, Zbigniew 2000. Portrety “obcego": Od stereotypu do symbolu. [Portraits of the Other: From Stereotype to Symbol.] Cracow: UJ. 
Bornemark, Joanna \& Ruin, Hans (eds.) 2012. Ambiguity of the Sacred: Phenomenology, Politics, Aesthetics. Södertörn Philosophical Studies, Vol. 12. Stockholm: Södertorn University.

Borowik, Irena 2003. Transformations of Catholicism and Religiosity of Catholics in Poland. In: I. Borowik (ed.) Religions, Churches and the Scientific Studies of Religion: Poland and Ukraine. Cracow: Nomos, pp. 41-59.

Bruce, Steve 2013 [2011]. Secularization: In Defence of an Unfashionable Theory. Oxford: Oxford University Press.

Caillois, Roger 2001. Man and the Sacred. Transl. by M. Barash. Urbana: University of Illinois Press.

Cameron, Euan 2010. Enchanted Europe: Superstition, Reason \& Religion 1250-1750. Oxford: Oxford University Press.

Czaczkowska, Ewa K. 2012. Siostra Faustyna: Biografia świętej. [Sister Faustina: The Biography of the Saint.] Cracow: Znak.

Donajska, Ryszarda 2014. Żyć Ewangelia: Biografia ks. Bronistawa Bartkowskiego spowiednika Stużebnicy Bożej Kunegundy Siwiec. [To Live by the Gospel: The Biography of Father Bronisław Bartkowski - the Confessor of Cunegonde Siwiec, the Servant of God.] Kraków: Wydawnictwo Karmelitów Bosych.

Eliade, Mircea 1997 [1988]. Historia wierzeń i idei religijnych. T. 1. Od epoki kamiennej ia do misteriów eleuzyńskich. [History of Religious Ideas. Vol. 1. From the Stone Age to the Eleusinian Mysteries.] Transl. by. S. Tokarski. Warszawa: PAX.

Exhumation = Ekshumacja Kunegundy Siwiec. [Exhumation of Cunegonde Siwiec.] Available at http://www.karmel.pl/ekshumacja-kunegundy-siwiec, last accessed on 11 October 2018.

Hukantaival, Sonja 2013. Finding Folk Religion: An Archaeology of 'Strange' Behaviour. Folklore: Electronic Journal of Folklore, Vol. 55, pp. 99-124. http://dx.doi. org/10.7592/FEJF2013.55.hukantaival.

Jakimowicz, Marcin 2009. Pocieszaj mnie, Kundusiu. [Comfort Me, Kundusia.] Gość Niedzielny, No. 24, 18 June. Available at http://gosc.pl/doc/803042.Pocieszaj-mnieKundusiu, last accessed on 11 October 2018.

Janicka-Krzywda, Urszula 2010. Górale Babiogórsy jako grupa etnograficzna. [Highlanders of Babia Mountain as an Ethnographic Group.] In: Urszula Janicka-Krzywda (ed.) Kultura ludowa Górali Babiogórskich. [Folk Culture of Highlanders from Babia Góra.] Cracow: Wierchy, pp. 23-36.

Kowalska, Faustyna 2000 [1981]. Dzienniczek: Miłosierdzie Boże w duszy mojej. [Diary: Divine Mercy in My Soul.] Warszawa: MIC.

Krzywda, Piotr 2010. Charakterystyka geograficzno-historyczna obszaru zamieszkiwanego przez Górali Babiogórskich. [The Geographical and Historical Characteristics of the Area Inhabited by Highlanders from Babia Góra.] In: U. Janicka-Krzywda (ed.) Kultura ludowa Górali Babiogórskich. [Folk Culture of Highlanders from Babia Góra.] Kraków: Wierchy, pp. 7-22.

Leśniewska, Ewa 2011. Kundusia z Siwcówki bliżej beatyfikacji. [Kundusia Closer to Beatification.] Gosc.pl, 30 October. Available at http://gosc.pl/doc/996945. Kundusia-z-Siwcowki-blizej-beatyfikacji, last accessed on 11 October 2018.

Orkan, Władysław 1946. Listy ze wsi i inne pisma społeczne: Wybór. [Letters from Rural Areas and Other Social Writing: A Selection.] Warszawa: Gebethner i Wolff. 
Otto, Rudolf 1958. The Idea of the Holy: An Inquiry into the Non-Rational Factor in the Idea of the Divine and Its Relation to the Rational. Transl. by J. W. Harvey. London \& Oxford \& New York: Oxford University Press.

Parsons, Talcott 1960. Structure and Process in Modern Societies. Glencoe, Ill.: The Free Press.

Rappaport, Roy 1999. Ritual and Religion in the Making of Humanity. Cambridge: Cambridge University Press. Available at https://zodml.org/sites/default/ files/\%5BRoy_A._Rappaport\%5D_Ritual_and_Religion_in_the_Maki.pdf, last accessed on 12 October 2018.

Riis, Ole \& Woodhead, Linda 2012 [2010]. A Sociology of Religious Emotion. Oxford: Oxford University Press.

Stinissen, Wilfrid 2001. Prosta droga do świętości: Śladem św. Teresyz Lisieux. [A Simple Path to Sanctity: In the Footsteps of St. Thérèse of Lisieux.] Poznań: W drodze.

Stomma, Ludwik 2002. Antropologia kultury wsi polskiej XIX w. oraz wybrane eseje. [Anthropology of Polish Folk Culture in the 19th Century: Selected Essays.] Łódź: Piotr Dopierała.

Thomas, William I. \& Znaniecki, Florian 1976 [1918]. Chtop polski w Europie i Ameryce. [The Polish Peasant in Europe and America.] Vol. 1. Warsaw: LSW.

Walczak, Andrzej 2002. Beskidzka katedra Prymasa Tysiąclecia. [The Beskid Cathedral of the Primate of the Millennium.] Stryszawa: Parafia św. Anny.

Waldenfels, Berhnard 2002. Topografia obcego. [Topography of the Other.] Transl. by J. Sidorek. Warszawa: Oficyna Naukowa.

Zieliński, Jerzy (ed.) 2010. Piękno ukryte w prostocie: Życie Stużebnicy Bożej Kunegundy Siwiec OCDS. [Beauty Hidden in Simplicity: The Life of the Servant of God Cunegonde Siwiec OCDS.] Cracow: Wydawnictwo Karmelitów Bosych. 


\title{
DYNAMIC MUSICSCAPES IN NORTHERN GREECE: A ROMA CASE STUDY
}

\author{
Christos Papakostas
}

School of Physical Education and Sport Science

National \& Kapodistrian University of Athens, Greece

e-mail: chpapak@phed.uoa.gr

\section{Dimitris Goulimaris}

Department of Physical Education and Sport

Democritus University of Thrace, Greece

e-mail:dgoulima@phyed.duth.gr

\author{
Maria Douma \\ MSc in Education Studies \\ University of Patras, Greece \\ e-mail:doumamaria@hotmail.com
}

\begin{abstract}
In recent years, there has been a considerable debate in social sciences concerning the relationship between place and culture, the dominant view being that this relationship is 'physical'. Groups have been identified as part of specific geographical spaces and their culture has been likewise considered as rooted in a particular territory. This theory is rather due to the phenomenon of nationalism, since part of its rhetoric is reinforced by substantiating the relationships among place, community, and culture. Lately, though, anthropologists have challenged the aforesaid essentialist approach. The concepts of culture and identity, disengaged from their correspondence with space, no longer constitute homogenous and static categories which define one group of people diachronically. This paper, based on the ethnographic example of the Roma (Gypsies) of Iraklia-Serres in Northern Greece, makes clear that, for the Roma, the term local (dopia) music is not monolithic, although it displays a high degree of relativity. In Roma professional logic, the concept of music is not constructed around final conclusions but is constituted by all kinds of practice, categorisation, and classification. What is enhanced in each case is the meaning of the music as an expression of place and identity. The Roma musicians, either as protagonists or as extras, represent their ethnic group and test the permeability of the boundaries (spatial, ethnic, symbolic), which are being continually repositioned in relation to the different reference points.
\end{abstract}

Keywords: ethnoscapes, identity, Gypsies, music, place, Roma 
If the zournas ${ }^{1}$-players are from Tzoumaya, there's nothing to worry about. This place produces the best instrument players, there's no doubt about it. The job will be done. (Kotas, personal communication, June 2001)

\section{MUSIC AND PLACE}

The main goal of this paper is to examine the relationship between music and the cultural identity of an ethnic group of people, as connected to the place they live in.

For many years, the dominant view has been that the relation between place and culture is 'physical'. Groups have been identified as part of specific geographical spaces, and their culture has been likewise considered as rooted in a particular territory. This approach is indicative of a taxonomic logic, which demands clear categories of cultures and cultural areas and is rather due to the phenomenon of nationalism, since part of its rhetoric is reinforced by substantiating the relation among place, community, and culture.

Lately though, anthropologists have challenged the aforesaid essentialist approach (Gupta \& Ferguson 1992; Olwig \& Hastrup 1997). New phenomena such as migration, diaspora communities, hybrid cultures and identities, the continuous circulation of materials and cultural goods or the development of new technologies have prompted re-examining the concept of 'culture/place' (Olwig \& Hastrup 1997: 3).

The concepts of culture and identity are disengaged from their correspondence with space and no longer constitute homogenous and static categories which define one group of people diachronically. Consequently, culture is perceived as a historical dynamic category which is in continual flux, being an object of negotiation of collective identities and heterogeneities (Nitsiakos 2006: 363).

The theoretical framework which initiated the present article is the theory of practice (Bourdieu 1977; Ortner 1984). According to this theory, music is formed by cultural practices 'through which a community manages its past and present, is reconstituted at a symbolic level and incorporates the elements of modern developments in its tradition, in a dynamic manner' (Nitsiakos 2006: 87). New ideas of place and identity as well as the relations among social groups, which are always relations of power, are incorporated in cultural practices and structure them. Practices are the ways and the fields through which these ideas 'are realized - that is, are understood and become real' (Cowan 1990: 16). This choice of theoretical framework helps us to overcome the dichotomy of structure/action and, consequently, to overcome the problem of substantiating the relationship between place and music. 
Music should not be perceived as a static cultural phenomenon, as a 'corpus' of stable and unaltered characteristics, but as a dynamic process 'historically determined and subjected to social and political manipulations and negotiations' (Nitsiakos 2006: 88). This perspective allows us to examine music beyond the view that it is identified with space, in other words, the view that music is rooted in a particular geographical territory.

Methodically, the paper is based on the results of systematic ethnographic fieldwork that took place between 2000 and 2002.

\section{THE ROMA IN/OF IRAKLIA}

Iraklia (formerly known as Tzoumaya) is a mixed community of semi-urban type $^{2}$ made up of individual ethnic groups. Today, the Vlachs, Roma (Gypsies), locals (dopioi), refugees, and a small number of Sarakatsani live together in Iraklia. This population mixture occurred after the end of the Balkan Wars and the Greeks' defeat in Asia Minor (1922). However, prior to these important historical milestones, Iraklia was inhabited by various Muslim populations and also the Muslim Roma. Since the mid-1970s, the semi-nomadic Tsinganoi also settled there. ${ }^{3}$

In general, the historical course of Iraklia is concurrent with the weakening of the Ottoman Empire, the constitution of Balkan nation-states (Mazower 2000), and their dispute over the geographical borders of Macedonia. Above all, in the case of Iraklia, this dispute resulted in significant spatial rearrangements caused by:

- Bulgarian and German occupation (1916-18);

- total destruction in 1916 and displacement of its inhabitants to Požarevac in Serbia;

- their return in 1918;

- rebuilding of the settlement in 1930 and its inclusion in the frontier zone of the newly-established Greek State.

The Roma are an inextricable part of the history of Iraklia, even though this is not recorded in the official textual sources (Aslanidis 1997; Kaftantzis 1973; Tzemailas 1973). The local elite, which mainly comes from the ranks of the Vlachs and is in charge of recording history, completely ignores the Roma and their role in the mixed community; any references to them are general and, mainly, in relation to music.

Nevertheless, the fact that the Roma are born in a mahala (neighbourhood ${ }^{4}$ ), which is a sub-space of the wider area of Iraklia, underlines their direct rela- 
tion with the particular space through ties of blood and land. They themselves consider this fact as proof of their localness. Furthermore, the space functions also as a geographical representation of the dipole 'we/others', since the mahala is opposed to the agora (marketplace), the space of the Vlachs. ${ }^{5}$ This observation is exceptionally important for the constitution of the Roma cultural identity, since they consider the mahala - and simultaneously Iraklia - as 'their place'.

\section{PROFESSIONAL MUSICIANS}

Vasilis Kaftantzis, an Iraklian of Vlach origin, in his book titled The History of Iraklia, and specifically in the chapter 'Intellectual and Artistic Activity', notes, inter alia:

The Tzoumayans were famed for their love of song and music. Indeed, it is noteworthy that most of the songs of its Vlachs are old folk klepht ${ }^{6}$ and love songs. Their lamentations are wonderful, too. But the Gyftoi ${ }^{7}$ of Tzoumaya, Christians, and Muslims, were also renowned for their musical prowess. Their music bands (made up of two shawms [zournades] - first and second - and a drum (daouli ${ }^{8}$ ), accompanied by one or, very often, two fiddles) were the only ones used in that period for weddings, patronal feasts, glendia ${ }^{9}$, and dances. One family predominantly of Christian Gyftoi, the Goras, with hereditary love of music and rare talent, produced instrument-players, zournatzides, such as Grigoris Goras, his son Vangelis and his grandson Grigoris, who became famous all over European Turkey. The Chitzios family also produced excellent instrument-players, the zournatzides Petros Chitzios, Kolias Chitzios, and his son Mitsios Chitzios, who had theoretical training and were able to play all the wind instruments. Another well-known professional musician, in great demand among the Turks and Christians, was the Tourkogyftos [Turk-Gypsy] Zorap, an outstanding fiddle player. (Kaftantzis 1973: 132-133)

The above excerpt is the sole potentially positive representation of the Roma in Kaftantzis's book. Thus, thanks to music, a whole group of people becomes 'visible' and gets out of the fringe of society. The skilfulness of the professional Roma musicians, Christians and Muslims, is the reason for the appearance of the Roma in the history of Iraklia. Still, there are some questions to be answered: To what extent is this professional occupation of the Roma their own choice and under what conditions was it formulated? Is it in fact a 'choice'?

Kaftantzis's reference to the 'hereditary love and true talent' of the Goras family is supported by a narrative that verges on myth: 
Once, a Turkish army pitched camp near Tzoumaya. Its commander had a horse trained to dance when it heard music. And so he invited the famed Goras (possibly Vangelis) ... who played best. (Kaftantzis 1973: 133)

During the course of fieldwork, several interviews and discussions were held with the zournatzis (shawm-player) Grigoris Goras, grandson of the 'old' legendary Grigoris Goras (son of Vangelis). Grigoris often returned to the subject of his grandfather and his musical ability, which in those years was acknowledged by all in Tzoumaya, both Christians and Muslims. Like Kaftantzis, Grigoris recounts vividly and dramatically the following folk legend:

And when he heard the bey [Goras, my grandfather play], he became jealous and he sent a ceta [group] of three men to behead him. They came to the house on their horses and, so the story goes, they said to him: 'Goras, come. We're taking you with us'. My grandfather understood the danger and said to my grandmother: 'Bring me the zournas'. At the time, the zournas was hanging on the wall, with its chains, with its things, just hanging. 'Fetch me the zournas from there'. My grandfather, with his zournas in his hand, was taken outside, to face those men on their horses, holding their swords, the 'scimitars', as we call them. My grandfather told them: 'Excuse me, but before you behead me, I'd like to play an Otur havaci [a table song]. Afterwards, you can do what you think fit'. My grandfather took his zournas and he began to play. While he was playing that very sweet melody, a nightingale perched on the mouthpiece of the zournas. Now, when the soldiers saw this, their swords fell from their hands and they said: 'Because we've sworn an oath to take a blood-stained sword to our bey, we'll cut off your little finger'. They indeed cut off his finger but even in pain, my grandfather kept playing. The song that he played, the 'Amus pehlivanas' as we call it, is very popular in Doxato, a town in our region, and is highly requested. ${ }^{10}$

The versions narrated by Grigoris and Kaftantzis, as representatives of the local elite, display remarkable elements of convergence or even coincidence. The myth is interesting not only to analyse morphologically, but also to read and interpret. If we agree with Barthes (1972) that 'myth is discourse', then what are the issues that this myth projects and negotiates? The element that is projected forcibly in all these versions of the myth is the Roma's given relation with music and their consequent ability to entertain, to amuse the 'other'. Concurrently, the myth also addresses the issue of the music's origin, since it identifies music with the Roma. Thus, it acquires the character of a myth of origin, a very important fact for the identity of the Roma, and is directly linked with the survival of the ethnic group. Generally speaking, the myth on the Roma's 
relation with music uses the past to serve contemporary or future objectives. Such intentions are revealed both through the myth and the historical events. Before the displacement of the Tzoumayans to Serbia, Christian and Muslim Roma played at feasts and ceremonies. In several cases, the cetas (bands) of musicians were created with the collaboration of Christian and Muslim musicians, so they were of mixed composition. The departure of the Muslim Roma ${ }^{11}$ left a professional vacuum, mainly in relation to music (Keil et al. 2002).

Apparently, professional opportunities for the Roma were usually found in those occupations which the others were less capable of undertaking or were reluctant to undertake (Okely 1983: 49). ${ }^{12}$ Thus, the Roma's involvement with music constituted a vital and attractive social space, which seemed logical and, moreover, had professional benefits. It is indicative that in many regions the definition of 'Gyftos' (Gypsy) is synonymous with that of 'musician'. This perception challenges or even cancels the myth that 'music runs in the Roma's blood' (Keil et al. 2002: 134), created by the works of classical Gypsy Studies, ${ }^{13}$ which develop a series of certainties about the 'gypsy culture' and project a 'genetic', 'inherent' relation between the Roma and music. ${ }^{14}$

By focusing on the discussion about the aims and ambitions of the Roma musicians of Iraklia within the new circumstances, created mainly after 1922, the following observations can be made:

- The Roma are interested in prevailing in this new market and in playing a central role in the emerging political economy of music (Attali 1985), as well as in widening their musical network. This is related directly to the cultural and economic survival of their ethnic group.

- The success of this endeavour depends on the degree of their immediate adaptation to the new conditions. The transformation of the ethnic mosaic, due to the re-installation of the refugees, imposes the Roma's familiarisation with new forms of musical performances and practices, new musical genres and repertoires: Thracian, Pontic, and Gagavouzan are some of the new musical idioms which the Roma are called upon to learn and execute. Such musical idioms are added to the Vlach, Greek, and Bulgarian local (dopia) ones, as well as to the European and urban musical idioms which they dealt with prior to 1922 . In other words, they simply provide the interested parties with the appropriate music and dance, according to the occasion.

Judging from the facts, the Roma apparently adapted successfully to the new circumstances in a rather easy way, which is also due to the fact that the professional practice of music is a basic cultural ethos (habitus) of the Roma community. Their very existence in the specific field depends directly on their musical skills and 'their fingers'. Therefore, adaptation should not be conceived as an essential or magical property of the Roma culture, but as a conscious 
activity of social subjects. Bauman (1999: 95) characterises this creative form of adaptation as a par excellence 'art of the weak'. The musicians are fully aware that they are part of a multivalent system of relations and consciously follow its rules. This does not mean total subservience but a continuous process of negotiation and creative adaptation, during which the musicians manage their musical knowledge and experiences so as to improve their way of life.

Consequently, the Roma musicians have to keep themselves up to date with the musical idioms, the forms of performance, and the musical preferences of the various ethnic groups in general. However, they do not only stay informed about musical trends, but are also interested in incorporating and shaping new musical idioms, which they introduce to society before they are even comprehended. Thus, the musicians-'prophets' as agents of change renew their cultural product, making it simultaneously more attractive and reinforcing the status of their cultural identity. In a way, Attali's argument (1985: 43) on the prophetic nature of music is confirmed, since it explores an entire field of possibilities more quickly than reality can succeed in doing'.

The Roma's authoritative and timely adaptation was also favoured by another influential historical conjuncture; the efforts of the newly-established Greek nation-state to create a cultural uniformity and homogenisation ${ }^{15}$ through manipulating the ethnic traditions and cultural forms. Deviant cultural practices (dances, songs, and customs) were deemed problematic and were even prohibited. As a result, bilingual ethnic groups such as the Slavophone 'Bulgarian dopioi', the Turcophone Gagavouzans, and the Cappadocians were considered 'a problem', when using any kind of cultural expression in the mother tongue. The communities were forced to comply with and conform to the demands of the nation-state, so as to avoid suffering painful consequences. Songs were forgotten, ${ }^{16}$ dances and customs declined, and the stigmatised communities expressed themselves within the imposed and permitted national framework. So, the communities adopted many songs and dances that the nation-state promoted through the school curriculum, such as kalamatianos, tsamiko, Makedoniaxakousti, and so on. ${ }^{17}$

Based on the same logic of control and prohibition, some musical instruments were also evaluated as elements of cultural heterogeneity, and their use was considered problematic (e.g. gaida (bagpipe), Macedonian lyra (lyre), accordion). As a consequence, these instruments disappeared from the music and dance performances of the communities, with the resultant creation of a great musical void. This situation led to the prevailing of the zournas (shawm), mainly in the region of Eastern Macedonia. ${ }^{18}$ The reasons could be sought in the following:

- The shrill and piercing sound of the zournas, and generally in the remarkable dynamic of the musical duo of zournas-daouli. 
- The fact that the dynamic of these instruments precludes the simultaneous musical performance, which leads to the weakening of the songs, the lyrics of many of which were not in the Greek language. ${ }^{19}$

- The presence of the zournas-players and the economic transaction between the musician and the host reinforced the prestige of the latter (RombouLevidi 2009).

- The fact that the zournas and the daouli were not evaluated as symbols of otherness or identified with problematic cultural practices and ethnic groups.

- The agents of these musical instruments themselves. Although they were members of a stigmatised ethnic group, Roma musicians were not seen as posing a threat to the nation-state. Consequently, they were able to move freely within a large geographical area and had access to a large number of communities and ethnic groups.

- The Roma's aesthetic and artistic interpretation of regional musical cultures, which gave a new, dynamic perspective to the music and dance of Eastern Macedonia.

However, it is wrong to argue that this interactive process concerned only professional musicians, although their attempt for a personal and ethnic selfexpression constitutes a very interesting example of folk creativity.

In each case, all the above consolidated the domination of the zournas over other musical instruments and functioned to the advantage of the musicians who were called upon to fill in new cultural voids and to respond to the needs of the other stigmatised ethnic groups (Rombou-Levidi 2009).

\section{MUSIC NETWORKS AND POLITICAL ECONOMY}

After the new territorial arrangements of the Greek nation-state, it is clear that the Roma could play their music in a wide geographical area. Consequently, the musicians were involved in a broad spectrum of relations, and in a multi-ethnic situation. ${ }^{20} \mathrm{~A}$ concept that facilitates the analysis of music as a professional activity of the Roma is the 'musical network'. Kavouras (1997: 42) notes: 'The concept of the network was established in anthropology as an alternative analytical category and gradually replaced the static terms of cultural area and the dualistic schemes "tradition/modernization" or "cultural centre / cultural periphery".' The interpretational model of the music network allows the analysis of the investigated subjects and the relations and practices they develop in space and time. Thus, the dynamic character of the network allows us to describe and analyse music, as well as cultural phenomena in general, 'as "open processes" and not as "closed structures"' (Gluckman 1968: 219-237). 
Within the framework of a peculiar political economy of music, the musicians are placed at the centre of the process, since they are the music 'producers' and they maintain relations of clientele with the individuals/members of other social groups, who must pay the entry fee for participating in a music-dance event (Attali 1985). Moreover, the musicians are placed at the centre of the music performances, which reproduces a unilateral model of power. The musicians themselves determine, to a considerable degree, the procedure of the musical performance and the public is restricted to an aesthetic relation with the melodies and the context of their production. However, in the case of rituals/ ceremonies that demand a strict canonistic framework, some limits are placed on the musicians' individual interpretative practice. ${ }^{21}$

OK, we know how to play but we're not the only ones in charge [...] they'll tell us what they want, they'll tell us 'yes, play it' [...] and then we've got to play well or we're in for it. (Pelekanos, personal interview 2001)

In the model described above, the term 'power' plays a decisive role. Undoubtedly, the musicians' musical knowledge plays an important part in the power of entertainment and amusement. ${ }^{22}$ However, one should wonder about the form and the duration of this power. During the performance, the player is not defined as 'Gyftos' but as a 'musician'. Once the performance is over, the definition 'Gyftos' returns. In other words, it is a rather manipulated form of power, which is probably conceded to the musicians in order to achieve an integrated musical performance, in accordance with the local criteria (Cowan 1990).

The ephemeral character of the musicians' power is confirmed by one further fact: they themselves are not recognised as physical persons but as metaphorical personifications of their instruments (Cowan 1990). 'The daoulia ${ }^{23}$ have arrived', 'the zournades are playing', 'I've booked the instruments for the wedding' are some phrases that are indicative of this view and that, finally, gives greater status to the instruments rather than to their agents (Keil et al. 2002: 95).

The poetic representation of the instruments coexists with, or even conveys, the social depersonalisation of their agents. Concurrently, this is a choice of the clients, so that the definition of the musicians as Gyftoi is toned down during the performance. An element promoted by all manner of clients is also the musicians' place of origin. The phrase 'the musicians from Iraklia' guarantees and contributes to the successful outcome of a performance. Localism, as well as the professional ability of the musicians, has a positive influence on the definition of their cultural identity.

We play at weddings, christenings; we play at glendia, at traditional feasts (panigyria), the kourbani ${ }^{24}$ or the koudounia ${ }^{25}$ at Kali Vrysi or Nikisiani. We'll go everywhere to play, because that's our job. We play at the wrestling 
event or the giures havaci ${ }^{26}$. One hour we're here, the next hour we're somewhere else. Most of the time, we're on the move. If we stay put in the mahala and Iraklia, we'll never earn our daily bread. When other folks are on holidays, we work hard. Our fathers also did the same job under the Turkish rule. They played for our own people, for the Vlachs, for the Turks, for everyone. (Kontos, personal interview 2000).

For the Roma, music as a profession presupposes constant alacrity and mobility, which ensures their economic survival and also constitutes a dynamic and multi-level process of defining their identity. The musicians travel from place to place, offering their 'wares' to heteroclite groups and communities.

The musicians' 'journey' creates a romantic content to several Gypsy studies and is classified among the inherent traits of the Roma (Liegois 1994). Possibly, the problem stems from the fact that specific studies are influenced by structural-functionalist theories (Politou 2000:19) and are orientated towards the study of itinerant or travelling Roma. This approach, which has been largely adopted by the European Union, analyses the singularity of the Roma as a derivative of an inter-social structure and a function which 'interacts with historical circumstances; yet, nonetheless, it remains basically the same' (Politou 2000: 21).

However, the example of the Roma musicians of Iraklia is quite the opposite. The starting point of their professional journey is the mahala, the permanent place of residence, which in fact endows them with a form of locality. The musicians' journey has a purpose, a starting point and a destination: the musicians know where they come from, where they are going, what they must do and how to do it, ${ }^{27}$ where they will pass, and when and where they will return. In this context, the relation between the musicians and the places in the network of their musical performance is enhanced.

What is the musicians' relation with the places in which they play? How do the others see them and how do they see themselves? The musicians practice their profession in multi-ethnic frameworks, traversing and intersecting geographical and ethnic boundaries. Professional ability is directly dependent on their ability to transcend the cultural boundaries and to respond to whatever form of local musical demands are made (Stokes 1994: 98). So, the musicians appear as 'supra-local', 'trans-local' and, perhaps more accurately, 'trans-ethnic'.

The Roma, as music producers, cut across the geographical and symbolic boundaries between various ethnic groups, and give the music network a transethnic character, while the mahala is the place from which they set off and to which they come back. In this way, the Roma live a peculiar form of experience, by which they are able to 'beat' at the same moment 'here', and to live simultaneously the 'local', the 'ethnic', and the 'trans-ethnic'. 
Every place has its own festive days and quirks. In some places there's a programme to follow, before the zournades can play... It is a difficult job, it needs patience. You've got to know about the place you go to. The zournades know their way about. We don't get lost. Most times we come back home to Iraklia straight away after the job, no matter what time it is. (Atakas, personal interview 2000)

The Roma's professional abilities are very important for the symbolic reconstitution of the communities and the ethnic groups they visit. Music is an attractive cultural form and it is related to the cultural reproduction of the local identity as well as to frameworks and occasions of community participation (Keil \& Feld 1994: 269), such as weddings, traditional feasts, and other local ceremonies in which the members of a community participate and in which musical performance has particular gravity. The main responsibility for performances of this kind is attributed to the musicians, who, being aware of their role, shape jointly and determine together with their audience a clear framework of action.

What, however, is the status of the musicians and how is their identity defined in relation to the 'recipient community' and the place in general? Their presence in a different place is entangled in a series of paradoxes which the nature of their work elicits and enhances. Notable among these paradoxes are the following:

1. Whereas as Gypsies they would go unnoticed, as musicians they are placed at the centre of the ceremony and the music performance, for as long as it lasts. Once this is over, their identity returns to its original state. The place of the ceremony is simply a workspace for them. In each case, the merchandise (music) is of greater importance than the merchant (Roma musician). 2. Although this is a case of 'matter out of position' (Douglas 1966), 'out of place', they participate decisively in the reconstitution of the place and the formation of the identity of the other, through their capacity as musicians. In this sense, during the musical performance they occupy a transient position in localism. Their presence is not limited merely to the level of the invitee (Lemon 2000: 4), but potentially one would consider them familiar 'guests', privileged and significant visitors or 'long-term' guests (Goffman 1961).

3 . They play an active part in the musical events and ceremonies of a community but they do not consider themselves as important as the members of that community do. They contribute to the codification and formulation of the messages and meanings only to the degree that serves their professional objectives.

4. In mixed communities in particular, that is, communities in which two or more ethnic groups coexist, the musicians' role is especially important. Their music contributes to communication between the individual groups of a mixed community and, to a degree, also to social cohesion. 
5. Their relationship with the locals at the moment of performance is based on a mesh of mutual collaboration and reciprocal concessions, and is under continual negotiation (Cowan 1990). It is impossible for a ceremony to take place without the participation of the musicians.

6. They are deemed to manage and provide 'authentic' music and traditions, yet without being considered authentic themselves. They are also considered as authentic local musicians but not entirely as authentic Greeks (Keil et al. 2002).

7. They use the concept of tradition for their professional consolidation, without participating in the rhetoric on tradition. We would argue that they simply 'play' tradition, without consciously thinking about it. This enables them to move easily between tradition and modernity.

\section{MUSICSCAPES}

Other crucial questions one should ask are: What kind of music do the Roma play in the places they visit? What are its characteristics and what is its relation with the place?

It seems that the musicians extract, borrow, and 'steal' music from their local, Vlach refugees or other sources, with the aim of making financial profit. However, in no case could one reproach them for lack of artistic concern and contribution. Therefore, the known stereotype of the Roma as musical 'thieves' should be restated, since it is through a consensual and not a violent process that the ethnic groups concede the rights to the use and interpretation of their music to the 'specialists'. The principal demand in this process is that the final product satisfies the cultural criteria and the aesthetic models of its ethnic sources and that it is recognisable.

Through the elaboration of this 'borrowed' musical culture, the musicians succeed in constructing a substitute musical form which is considerably different and whose signs of the dominant group are present, though merely recognisable. The result is a musical collage of unexpected proximities, in which similarity coexists with heterogeneity.

Mostly, the music that the Roma co-formulate and manage in the end is a product of a progressive differentiation and reciprocal influence. This approach downgrades the bipolar 'authenticity/alienation' (Adorno 1941), 'folklore and fakelore' (Harker 1985), 'real and invented traditions' (Hobsbawm \& Ranger 1985 [1983]), 'pure folk culture / folklorism', which in each case merit study with regard to their ideological function. 
This differentiated music, like the musicians who play it, transcends the conventional geographical and ethnic boundaries. Being initially local, it later becomes super-local and trans-ethnic. Still, one cannot speak of authentic, pure and unadulterated musical repertoires or genres. The music of the Thracians, Vlachs, Pontics, etc., belongs to fluid and loose categories, given different meanings each time, and always dependent on the frame of reference. In an integrated nation-state, terms like 'authentic' or 'pure' refer generally to a secure historical or ethnic origin.

One should think that the terms 'repertoire' and 'genre' are inadequate for capturing this reality (Papakostas 2007; 2008), especially in cases such as European, urban, and laiki (popular) music. Through these terms, place corresponds to just one musical culture and vice-versa, while at the same time one focuses on the comparative study of musical idioms and their strict geographical distribution. The example of the musicians of Iraklia and their professional involvement with music confirms Gupta and Ferguson's (1992) view that the isomorphism between space, place, and culture is not tenable but is constructed by the nation-state and is imaged in the feeble taxonomic schemes of 'repertoire' and 'genre'. The musicians, with their continuous mobility, do not weaken localisms but enhance them with a dynamic meaning. In a strange way, with the music they provide for the places and the groups they visit, they seem to cancel, yet at the same time confirm, their geography.

Keil (Keil et al. 2002) notes that the musicians of Iraklia play many different musical genres for each ethnic group. In general, this argument is acceptable and it also reveals the particularity and the dynamism of the Roma's musical practices. However, analysing the Roma's musical performance in different places, one could argue that the musicians have formulated a pliable and fluid musical form which is composed of the sum of individual genres and which in general terms is presented considerably homogenised because, perhaps, of the abilities and range of the zournas. This form is accessible and recognisable in many places and by many different ethnic groups in the wider geographical space of Eastern Macedonia, and even further. It includes certain $s^{y r t a}{ }^{28}$, ciftetelia $^{29}$, karsilamades ${ }^{30}$, chasaposervika ${ }^{31}$, zebekika ${ }^{32}$, and table songs, familiar melodies, rhythms, and musical scales (dromoi), which transcend the boundaries of the local, the Macedonian, the Ottoman, and the Balkan, while at the same time it is in a continual dialogue with localism, without threatening it.

The process of building this musical form is based on the professional reflexes of the musicians and their dialectical relationship with the available, emergent, and promoted musicscapes. In this sense, it is a musical form that becomes a common musical meeting place, concentrating and transforming heteroclite and heterogeneous cultural and musical elements. This is a dynamic 
and dialectic field between tradition and modernity, local and non-local, Greek and non-Greek, Macedonian and non-Macedonian, Balkan and non-Balkan, folk and popular, urban and 'peasant', and last, between old and 'fashionable' (Rice 1994: 305-309). The fluidity and the constant renewal and mobility of this common musical place excludes a space of cultural purity and simplicity.

\section{SUMMARY AND FURTHER CONSIDERATIONS}

What the ethnographic example of Iraklia makes clear is that for the Roma, the term local (dopia) music is not monolithic but displays a high degree of relativity. In Roma professional logic, the concept of music is not constructed around final conclusions, but it comprises all kinds of practices, categorisation, and classification. What is enhanced in each case is the function of the music in the process of acknowledging place and identity.

The idea that music simply reflects structures has been criticised by numerous researchers (Cohen 1982; Stokes 1994), since beyond the theory of the 'reflection' of social structures, music is believed to provide the meanings via which the hierarchies of the place are negotiated, transformed (Stokes 1994), and indicative of the place and the social groups. It is simultaneously a product and a process.

The words of the music theorist Simon Frith concur with the above attitude, when he emphasises: 'Music defines a space without boundaries, a game without frontiers' (Frith 1996: 125). In this game, the musicians - either as protagonists or as extras - represent their ethnic group and test the permeability of the boundaries (spatial, ethnic, symbolic), which are continually repositioned in relation to the different reference points.

As emerges from ethno-musicological studies in the Balkans (Pettan 1996; Silverman 1996; Statelova 1998), for all its singularities the example of the Roma of Iraklia is not unique. The hearths and homes of Roma musicians with similar or even different practices are located in all the nation-states of the Balkans. In all these cases the music they play transcends the ethnic boundaries and successfully copes with the cultural plurality of the clients, through a coherent unification of their musicality.

\section{NOTES}

1 Shawm, a medieval form of the oboe.

2 According to the 2001 census, the population of Iraklia was 3,609 people and that of the wider homonymous municipality 13,173 . 
${ }^{3}$ It should also be taken into account that in northern Greece the term Gyftos refers to a permanently settled population, whereas the term Tsinganos refers to migrating or itinerant ones, which is contrary to southern Greece (see Exarchos 1996; Hunt 1999).

4 A section of a rural or urban settlement, dating to the times of the Ottoman Empire.

5 See Gupta \& Ferguson (1997: 13).

6 A Greek brigand or independence fighter.

7 Gypsies in Greek.

8 Traditional percussion, also known as tapan or davul.

9 Party or other social event that includes food, music, and dance.

${ }^{10}$ Grigoris recounts an almost identical version to Charlie Keil (Blau \& Keil \& Feld 2002: 116-117).

${ }^{11}$ According to oral testimonies of the Roma of Iraklia, the new place of settlement of the Muslim Roma was Kessani in East Thrace.

${ }^{12}$ As the zournas-player Mitsos Chintzos characteristically put it: 'The Gyftoi do what the others don't do'.

${ }^{13}$ See, e.g., Webb 1975, Clebert 1976.

${ }^{14}$ Rasmussen (1996) calls it 'innate'.

${ }^{15} \mathrm{Cf}$. Wade (2000) on the way in which the state negotiated the paradoxes of homogeneity and heterogeneity.

${ }^{16}$ E.g. bouriana and gneskasamtuk.

${ }^{17}$ Several communities, in an effort to preserve their songs and dances, as well as to avoid punishment by the mechanisms of the authorities, were led to an intermediate solution: they translated the verses of the songs and the titles of their dances into Greek. This certainly influenced the structure of the songs and dances, and the way in which they were performed. Nonetheless, this is an interesting form of negotiation and adaptation, which merits further investigation.

${ }^{18}$ It should be stressed that although the zournas was not necessarily the principal musical instrument in many communities of Eastern Macedonia, its sound was nevertheless familiar. These communities preferred their local musical instruments in the musical and dance occasions associated with the symbolic reconstitution of the community. In a few cases, they invited zournades and daoulia to play at the wedding. See also Rombou-Levidi 2009.

${ }^{19}$ A rare example of the coexistence of song and zournas is found at Nikisiani, Pangaio municipality. The singers, many of whom are excellent church cantors, sing the local songs to the accompaniment of the zournas and daouli.

${ }^{20}$ Cf. Seeger 1977.

${ }^{21}$ Even in the case of the free entry-treat, chartoura or 'stalo', as it has come to be called by the Roma musicians, the musicians have to earn it through the fullness, correctness, and aesthetic appeal of their performance.

${ }^{22}$ Cf. Foucault 1980. 
${ }^{23}$ Players of daouli.

${ }^{24}$ Traditional customs/rituals based on the idea of shared food (meat). In many cases kourbani involves music and dance events.

${ }^{25}$ Bells.

${ }^{26}$ The melody that musicians play during the traditional wrestling games.

${ }^{27}$ These are the views of Theodosiou (2003) on the Gyftoi musicians at Parakalamos, Ioannina.

${ }^{28}$ Typical Greek line dance in circle (7/8 or $\left.2 / 4\right)$.

${ }^{29}$ Belly dance.

${ }^{30}$ Dance in pairs, face to face.

${ }^{31}$ Very popular dance form in $2 / 4$.

${ }^{32}$ Improvisational dance.

\section{REFERENCES}

Adorno, Theodor W. 1941. On Popular Music. Zeitschrift für Sozialforschung, Vol. 9, No. 1, pp. 17-48. http://dx.doi.org/10.5840/zfs1941913.

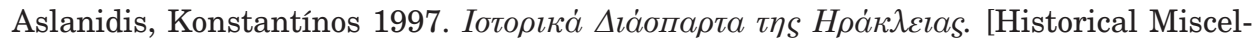
lanea of Iraklia.] Sérres: Dimotikí Vivliothíki Iráklias.

Attali, Jaques 1985. Noise: The Political Economy of Music. Minneapolis \& London: University of Minnesota Press. Available at https://monoskop.org/images/6/67/ Attali_Jacques_Noise_The_Political_Economy_of_Music.pdf, last accessed on 18 October 2018.

Barthes, Roland 1972. Mythologies. Transl. by Annette Lavers. London: Paladin.

Bauman, Zygmunt 1999. Culture as Praxis. London \& Thousand Oaks \& New Dehli: SAGE.

Bourdieu, Pierre 1977. Outline of a Theory of Practice. Cambridge: Cambridge University Press.

Clebert, Jean Paul 1967. The Gypsies. Transl. by Charles Duff. Harmondsworth: Penguin.

Cohen, Anthony P. (ed.) 1982. Belonging: Identity and Social Organization in British Rural Cultures. Manchester: Manchester University Press.

Cowan, Jane K. 1990. Dance and the Body Politic in Northern Greece. Princeton: Princeton University Press.

Douglas, Mary 1966. Purity and Danger: An Analysis of Concepts of Pollution and Taboo. London: Routledge.

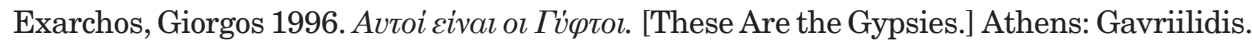
Foucault, Michel 1980. Questions on Geography. In: C. Gordon (ed.) Power/Knowledge: Selected Interviews and Other Writings 1972-1977. New York: Pantheon Books, pp. 63-77. Available at https://monoskop.org/images/5/5d/Foucault_Michel_ Power_Knowledge_Selected_Interviews_and_Other_Writings_1972-1977.pdf, last accessed on 18 October 2018. 
Frith, Simon 1996. Music and Identity. In: Stuart Hall \& Paul du Gay (eds.) Questions of Cultural Identity. London \& Thousand Oaks \& New Delhi: SAGE, pp. 108-127.

Gluckman, Max 1968. The Utility of Equilibrium Models in the Study of Social Change. American Anthropologist, Vol. 70, No. 2, pp. 219-237. http://dx.doi.org/10.1525/ aa.1968.70.2.02a00010.

Goffman, Erving 1961. Encounters: Two Studies in the Sociology of Interaction. Indianapolis: Bobbs-Merrill.

Gupta, Akhil \& Ferguson, James 1992. Beyond "Culture": Space, Identity, and the Politics of Difference. Cultural Anthropology, Vol. 7, No. 1, pp. 6-23. http://dx.doi. org/10.1525/can.1992.7.1.02a00020.

Gupta, Akhil \& Ferguson, James (eds.) 1997. Culture, Power, Place: Explorations in Critical Anthropology. Durham: Duke University Press.

Harker, Dave 1985. Fakesong: The Manufacture of British 'Folksong', 1700 to the Present Day. Milton Keynes: Open University Press.

Hobsbawm, Eric \& Ranger, Terence 1985 [1983]. The Invention of Tradition. Cambridge: Cambridge University Press.

Hunt, Yvonne 1999. Yiftos, Tsinganos: A Note on Greek Terminology. Journal of the Gypsy Lore Society, Series 5, Vol. 9, No. 1, pp. 71-78. Available at https://babel. hathitrust.org/cgi/pt?id=inu.30000071184661;view=1up;seq=259, last accessed on 9 November 2018.

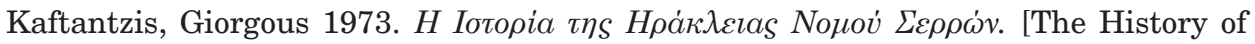
Iraklia in the Prefecture of Serres.] Iraklia Serres: Municipality of Iraklia.

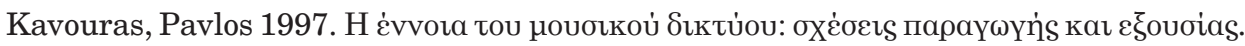

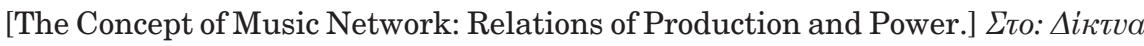

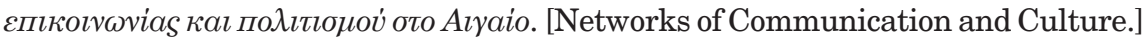
Proceedings of the 3rd Symposium for the Aegean Culture in Samos. Athens: Pnevmatiko Idrima Samou Nikolaos Dimtriou, pp. 17-36.

Keil, Charles \& Feld, Steven 1994. Music Grooves: Essays and Dialogues. Chicago: University of Chicago Press.

Keil, Charles \& Vellou Keil, Angeliki \& Blau, Dick \& Feld, Steven 2002. Bright Balkan Morning: Romani Lives and the Power of Music in Greek Macedonia. Middletown, Connecticut: Wesleyan University Press.

Lausevic, Mirjana 2007. Balkan Fascination: Creating an Alternative Music Culture in America. New York: Oxford University Press.

Lemon, Alaina 2000. Between Two Fires: Gypsy Performance and Romani Memory from Pushkin to Post-Socialism. Durham: Duke University Press.

Liegeois, Jean-Pierre 1994. Roma, Gypsies, Travellers. Strasbourg: Council of Europe. Mazower, Mark 2000. The Balkans. New York: Random House.

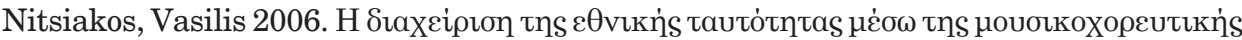

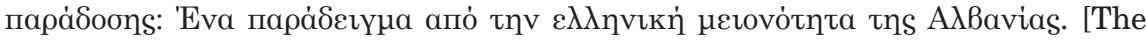
Management of National Identity through Music and Dance Tradition: An Example of the Greek Minority in Albania.] In: K. Panopoulou (ed.) Xopós kal

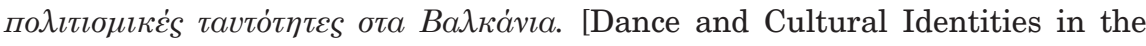
Balkans.] Proceedings of the 3rd Conference on Folk Culture. Department of Physical Education \& Sport Science, Municipality of Serres, pp. 363-372.

Okely, Judith 1983. The Traveller-Gypsies. Cambridge: Cambridge University Press. 
Olwig, Karen Fog \& Hastrup, Kirsten (eds.) 1997. Siting Culture: The Shifting Anthropological Project. New York: Routledge.

Ortner, Sherry B. 1984. Theory in Anthropology since the Sixties. Comparative Studies in Society and History, Vol. 26, No. 1, pp. 126-166. http://dx.doi.org/10.1017/ S0010417500010811.

Papakostas, Christos 2007. Repertoire: Theory vs Practice: The Greek Paradigm. In: Rethinking Practice and Theory. Proceedings of the International Symposium on Dance Research. 30th Annual Conference, Centre National de la Dance. Paris, France, 21-24 June. Riverside, CA: Society of Dance History Scholars, pp. 374-378.

Papakostas, Christos 2008. Dance and Place: The Case of a Roma Community in Northern Greece. In: Anthony Shay (ed.) Balkan Dance: Essays on Characteristics, Performance and Teaching. Jefferson, N.C.: McFarland Publishers, pp. 69-88.

Pettan, Svanibor 1996. Gypsies, Music and Politics in the Balkans: A Case Study from Kosovo. World Music, Vol. 38, No. 1, pp. 33-61. Available at https://www.jstor. org/stable/i40079773, last accessed on 18 October 2018.

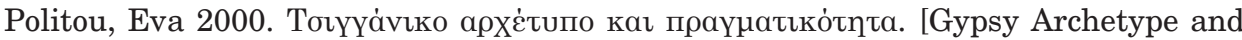

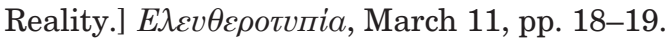

Rasmussen, Ljerka 1996. Orientalism, Rom Gypsy, and the Culture at Intersection. In: Ursula Hemetek \& Emil H. Lubej (eds.) Echo der Vielfalt / Echoes of Diversity: Traditionelle Musik von Minderheiten / ethnischen Gruppen / Traditional Music of Ethnic Groups / Minorities. Wien \& Köln \& Weimar: Böhlau, pp. 247-254.

Rice, Timothy 1994. May It Fill Your Soul: Experiencing Bulgarian Music. Chicago: The University of Chicago Press.

Rombou-Levidi, Marica 2009. Dancing beyond the 'Barre': Cultural Practices and the Processes of Identification in Eastern Macedonia, Greece. Diss. (PhD Thesis). University of Sussex, United Kingdom.

Seeger, Anthony 1977. Studies in Musicology, 1935-1975. Berkeley \& Los Angeles \& London: University of California Press.

Silverman, Carol 1996. Music and Marginality: Roma (Gypsies) of Bulgaria and Macedonia. In: M. Slobin (ed.) Retuning Culture: Musical Changes in Central and Eastern Europe. Durham: Duke University Press, pp. 231-253.

Statelova, Rosemary 1998. Sociocultural and Geopolitical Tensions Expressed through Identification with Regional Balkan Music and Its Local Variants. Music on Show: Folk traditions, Vol. 25. Finland: Tampere University Printing Service.

Stokes, Martin (ed.) 1994. Ethnicity, Identity and Music: The Musical Construction of Place. Oxford: Berg Publishers.

Theodosiou, Aspasia 2003. Authentic Performances and Ambiguous Identities: Gypsy Musicians on the Greek-Albanian Border. Diss. (PhD Thesis). University of Manchester.

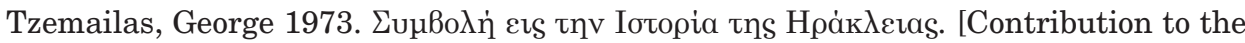
History of Irakleia.] Serraika Hronika, Vol. 6. Athens: Historical and Folklore Society of Serres-Melenikou.

Wade, Peter 2000. Music, Race, and Nation: Musica Tropical in Colombia. Chicago: The University of Chicago Press.

Webb, Godfrey 1975. Gypsies: The Secret People. London: Greenwood Press. 


\title{
ON A POSSIBLE CHARACTERISTIC OF THE GOVERNING SYSTEM OF PHARAOH AMENHOTEP IV (AKHENATEN)
}

\author{
Tarmo Kulmar \\ Chair of Comparative Religious Studies \\ University of Tartu, Estonia \\ e-mail:tarmo.kulmar@ut.ee
}

\begin{abstract}
The article explores the relationship between the religious reform of Pharaoh Amenhotep IV (Akhenaten) of the New Kingdom of Ancient Egypt and the changes in the governing system. The analysis, which is based on historical data and structured after the concept of the early totalitarian state set forth by the author, reveals that Akhenaten's governing system corresponds (almost) fully to that of an early totalitarian state in terms of historical and political causes and ideological factors, and partly in terms of administrative and legislative systems, whereas only an occasional feature of early totalitarianism is observable in economy and social order. No features of early totalitarianism in Akhenaten's governing system are manifested in foreign policy. It can be concluded, quite confidently, that Pharaoh Amenhotep IV (Akhenaten) was heading towards an early totalitarian form of government and that Akhenaten's experiment may have been one of the first known endeavours in the history of mankind to establish an early totalitarian state.
\end{abstract}

Keywords: Amenhotep IV (Akhenaten), Ancient Egypt, early totalitarianism, government, ideology, monotheism, religion

\section{INTRODUCTION}

The following is a research of the revolutionary steps in the realm of religion undertaken by Amenhotep IV (1350-1334 BC)1, one of the foremost monarchs of the so-called imperial, or New Kingdom, period (1570-1070 BC) $)^{2}$ of Ancient Egypt, with the focus on how the religious reform was reflected in his governmental actions. First, a brief overview is given of the socio-political structure that had evolved in Egypt by the time of the eighteenth dynasty (1570-1293 BC) of the New Kingdom, which is followed by a scrutiny of Amenhotep IV's major measures in domestic policy. Finally, his activities are assessed against 
the concept of the so-called early totalitarian state. The author's objective is to investigate whether and to what extent it is possible to refer to the governing system of Amenhotep IV (Akhenaten) as an early totalitarian state.

The primary written sources for the period under study are the Amarna epitaphs and epigraphs (incl. hymns to Aten) and the Amarna Letters (see, e.g., Murnane 1995; Moran 1992). May it be emphasised hereby that the author is not an Egyptologist and therefore relies on the works of renowned scholars, using the material on Ancient Egypt only to illustrate his aforementioned concept. The author considers it necessary to explicitly emphasize the methodological fact that this paper focuses primarily on the development of early totalitarian conception, at which the data is only evidence of Egyptology. In this regard, however, the professional Egyptologists should be trusted.

\section{THE NEW KINGDOM, AMENHOTEP IV (AKHENATEN) AND HIS REFORMS}

By the time Pharaoh Amenhotep IV acceded to the throne, Egypt had become the most powerful nation of the ancient world, especially thanks to the military might resulting from the successful campaigns, expedient political deals and skilful administration of his able predecessors Thutmose III and Amenhotep III, domestic stability, and economic prosperity. According to a widely accepted view (e.g. Grimal 1992; see also Doherty 2004: 33-44), the unifying factors for the state were as follows:

- The pharaoh as a ruler of essentially unlimited power, who was simultaneously the political, military and religious ruler, the intermediary between people and gods, was worshipped as a living god on earth.

- In addition to the patron gods of the nomes, a pantheon of deities highly venerated all over Egypt had evolved. Preeminent were Amun-Ra (Amun, once the patron god of Thebes, had become the chief god and merged with the sun god Ra), the fertility gods Osiris and Isis, and the personification of the world order Maat.

- The army, which included the infantry, the cavalry, the chariotry, and the navy, was comprised of professional and, in wartime, forcibly conscripted soldiers, as well as of foreign mercenaries. Law and order were enforced by garrisons stationed in key centres.

- An influential priesthood, especially the high priests, to whom the principal religious duties of the pharaoh were delegated. The highest-ranking of them was the chief priest of the Amun-Ra temple in Thebes, whose authority 
tended to jeopardise pharaonic power, especially in the final stages of the New Kingdom. The temples were important centres of economy, education, and culture.

- The officialdom, which partly coincided with the lower priesthood, was composed of the scribes, the accountants, and the supervisors. Owing to clan relationships, access to classified information and high positions in the court, a great many of them were corrupt (to use the modern terms).

- Central rites, such as the rite of Osiris, dedicated to the rebirth and periodic revival of nature, as well as the cult of the dead and the other world, which signified preparation for death from fairly early on in one's lifetime, including, if possible, the construction of a tomb and the accumulation of means for mummification and for copious grave goods in order to ensure eternal life.

We see that apart from political, economic, and social factors, religious and - in modern terms - ideological ones were at least as important.

The pharaoh's birthname was Amen-Hotep (Amun is Satisfied). In the fifth year of his rule, he adopted a new birthname - Akhen-Aten (Pleasing to Aten). Yet, all through his reign he had one and the same royal, or throne, name: Nefer-Heperura-Ra (Beautiful Are the Regeneses of Ra) (Clayton 2001: 120). He was the second son of Amenhotep III and his main wife (Great Royal Wife) Tiye. He was probably asked to accede to the throne after the death of his elder brother, to become coregent with his father in the final years of the latter's life, as was customary in Egypt. He staged his coronation in the temple of the sun god Ra-Harakhte at Hermonthis in South Egypt (Jacq 2000: 46), married Nefertiti - daughter of Minister Aye, his mother's (Queen Tiye's) brother (i.e. his uncle's daughter) (Jacq 2000: 120-121; see also David 2005: 206) - who, based on the busts found from the ruins of Tell el-Amarna, may be considered one of the most beautiful women in history; may it be mentioned that the name "Nefertiti" meant "The Beautiful One Has Returned" (Stadnikov 1998: 320). Thus, the first four or five of the seventeen years of Amenhotep IV's reign were completely conventional. The revolutionary measures were delayed until the next decade.

Although initially the pharaoh had himself be depicted, as the custom went, with the chief god Amun, he started to increasingly prefer the sun disc Aten. This aspect of the sun god Ra had already been venerated by his predecessors Thutmose IV and Amenhotep III. Amenhotep IV built an Atenist temple at Karnak in Thebes and gave a new meaning to the cult of Aten. After changing his birthname to Akhenaten, he initiated a systematic reformation, increasingly resorting to repressive means, among others. 
As a first measure, Amenhotep IV removed from Thebes the high priest of the temple of Amun, sending him to an eastern desert to lead an expedition, for the priesthood of the old chief god Amun was undoubtedly the main enemy of the new religious movement. At Karnak, he built the aforementioned temple to Aten, a vivid expression of the new artistic style, after which the pharaoh was portrayed in a naturalistic manner, with his physical properties, a phenomenon unprecedented until then. Artistically, he now had Aten depicted as the sun disc, the only anthropomorphic feature thereof being human hands at the ends of the rays. Theologically, it denoted the idea of a universal world religion, according to which Aten was the god besides whom there was no other (Stadnikov 1998: 317). Ethnically, it was echoed in an equally unparalleled idea that in Aten's eyes all peoples and languages (see Assmann 1975: 218-219), Egyptians and foreigners alike, had the same worth (see Hornung 1978 [1965]: 99), since they were all Aten's children. It is fairly certain, however, that Akhenaten did not preach the equality of all people, this being implied in the fact that in the first period of the reformation there was no persecution of either the old gods or their worshippers, who constituted an overwhelming majority of the Egyptian population. In addition, Akhenaten ousted a large part of the old officialdom, inviting into his court officials, military officers, and priests who did not descend from the upper class or were even foreigners. The pharaoh was raising allies for himself.

Having prepared a base of loyal supporters, Akhenaten progressed to the central phase of his endeavours. Here, likewise, several stages can be distinguished.

Firstly, he abandoned both the new capital, Thebes, and the old one, Memphis, and founded between them, approximately halfway from either end, a new royal capital Akhet-Aten (The Horizon of Aten). It was a solitary site with no ties to cults of other gods. Nowadays, this site is identified as Tell el-Amarna. Probably, Akhenaten himself had been among the authors of the very exceptional layout of the city. The economic policy of the state had to be restructured, as hosts of unskilled and skilled labour were to be forcibly redirected there, as was a substantial share of the revenue in order to procure building materials, provisions, and other requisites (Jacq 2000: 62-65). Owing to the fast pace, the massive construction works bore marks of great haste (Jacq 2000: 74). The new court, headed by Akhenaten, moved into the uncompleted city already the next year. After Akhenaten's death, Akhetaten was deserted (about Akhetaten, see, with references, Wilkinson 2013: 244-246 and 465-468; also Darnell \& Manassa 2007: 189-196; David 2005: 209-214). This, too, was unprecedented in Egyptian history, which epitomised the tradition of permanence and continuity. 
Secondly, as the opposition of the priests of Amun evidently grew and the anti-Atenist agitation all across the nation undoubtedly intensified, Akhenaten set out, as a countermeasure, to destroy the cult of Amun in the fifth year of his reign at the latest. Attempts were made to erase the name of Amun from inscriptions everywhere in order to doom it to oblivion. The enmity was also extended to the other gods. Akhenaten proclaimed that Aten no longer tolerated the existence of any other deity, disbanding their priest and redirecting the revenue from their temples to Aten's benefit (David 2005: 209). Compliance with the command was monitored by the pharaoh's security service, and those remaining loyal to the old religion were repressed (Wilkinson 2013: 253-254; Jacq 2000: 150ff.).

A god being proclaimed false and his cult being decreed to destruction was an unheard-of action in the then history of not only Egypt but probably of the whole of humanity.

At the same time, Akhenaten promoted the cult of Aten as a monotheistic one, which was alien to the Egyptians theologically as well as ritualistically. The rich mythology of the earlier religion was brushed aside altogether, supplanted by hymns to Aten, part of which were probably composed by Akhenaten himself (see, e.g., Wilkinson 2013: 251-252; Lichtheim 1976: 96-99; David 2005: 215-217). The temples to Aten contained no sanctuaries or cultic images. The primary feature of the rite was that the chief priest of Aten was Akhenaten himself, the king being the only earthly representative of the god. Unlike the previous rites, which were conducted in temples, the king was worshipped as a god in his palace (see Shafer 1997: 180-183). Special emphasis was on public processions, which had a profound effect (Jacq 2000: 146ff., 178). The cult of the monarch and his family as the so-called domestic deities even developed, which again was an entirely novel phenomenon in Egyptian religion (see Morenz 1984: 155; Assmann 1984: 251-253). In essence, Aten and Akhenaten had become one. Hence, it represented an extraordinary - even a totalistic - attempt to absolutise the king's person (see Dodson 2009; Stadnikov 1998: 43), which included both the secular and the religious realm.

Such radical measures incurred a series of setbacks. By relocating to a new capital, Akhenaten largely removed himself from reality, as the relatives of the previous pharaoh, the authoritative figures in the old court and the competent officials, whose power Akhenaten failed to conclusively break, effectively continued to govern Egypt from both of the old capitals. After all, the state had to function.

The cults of the chief god Amun and of the other gods did not cease either. The priests of Amun, who wanted to maintain their leading position in the 
religious life of the nation, incited anti-Atenist sentiments. The majority of the common people continued to worship the old gods, since the mysticist Atenist theology was simply incomprehensible to the peasants and urban paupers.

It may be assumed that in reality the Atenist ideal state existed only on the narrow strip of Akhetaten. Disagreeable facts were withheld from the pharaoh; he was ill-informed of the actual situation in the state (see, e.g., Jacq 2000: 178). Taxes came in irregularly, an escalating economic decline (Jacq 2000: 182) prompted sporadic boycotts and local rebellions, which the pharaoh strove to suppress mainly with the help of foreign mercenaries (Stadnikov 1998: 319).

The foreign policy of the Egyptian Empire was disastrous. As appears from the copious cuneiform correspondence with governors and other rulers of the subjugated regions found from the ruins of Amarna (see Moran 1992), Egypt lost its influence over almost all the territories in Syria and Palestine, which had previously been under its vassalage. The reason was both the pharaoh being busy with domestic policy problems and the Hittite-led revolts. It was not until the time of the nineteenth dynasty that Egypt managed to restore a measure of its once glorious foreign policy.

The fiascos in domestic and foreign policy were coupled with flaws in the pharaoh's private life. Nefertiti bore Akhenaten six daughters, who evidently were handicapped either physically or mentally and did not all reach adulthood. In the last years of the pharaoh's reign, Queen Nefertiti disappears from the annals; apparently she fell into disfavour and died young. In the last three years of his life, Akhenaten co-reigned with his son-in-law Semenhkara, who managed to strike a compromise with the priests of Amun. This so-called restoration period may be regarded as one of dual religious power. Under Ay, Tutankhamun, and Horemheb, the rulers after Akhenaten's death, the cult of Aten gradually faded into oblivion and the old religion was restored relatively peacefully. Systematic annihilation of the memory and memorials relating to Akhenaten did not begin until the nineteenth dynasty pharaohs Seti I and Ramesses II (Jacq 2000: 210).

Akhenaten's so-called revolution failed, for he tried to forcibly impose religious ideas that remained incomprehensible to the people for the lack of, among others, a nationwide cult and a motivating mythology, as well as for the fact that the new religion pursued to perpetuate a non-Osiric concept of the afterlife and terminate the habitual burial customs (David 2005: 229-230). The religion of Aten did not muster the support of the upper classes due to political and economic reasons.

In fact, religious ideologies reflecting universalistic tendencies as well as pursuits of implementing such ideas have surfaced all through the long history 
of the ancient Egyptian state (see Stadnikov 1998: 93-142, with extensive literature on the topic). In this regard, Akhenaten is no exception. Despite radical and resolute measures, however, his effort failed, for the idea of monotheism was alien to the Egyptians. It has been suggested (Hornung 1983: 191ff.; 1992: 43-49) that the traditionally polytheistic Egyptians could not conceive of the oneness of god and therefore of monotheism, and that the introduction of monotheism automatically involved a fundamental shift in logic. With his action, Akhenaten changed the traditional beliefs too radically (see Aten's Hymn, Lichtheim 1976: 96-100). Perhaps the venture would have met with more success had the religious reform been effected in stages and Aten initially promoted as one of the henotheistic main gods among others.

One of Akhenaten's motives was undoubtedly his religious perceptions, and to an extent he was an idealist, which is manifested, among others, in his exodus to Akhetaten - his 'kingdom of Aten'. Furthermore, neither the Atenist theology nor Akhenaten's religious worldview (which, in essence, were one and the same!) had any room for the dark sides of real life (Stadnikov 1998a: 319). On the other hand, one must not underestimate his ambition for political monocracy, to that end eliminating powerful political groupings (the priests of Amun, the old aristocracy, and the corrupt high officialdom); as well, he had enough resolve to employ repressive measures, which enabled him to reign as long as he did (Darnell \& Manassa 2007: 189-196). Accordingly, it appears that the scholars who have tried to demonstrate that Akhenaten used the cult of Aten to suppress the priests of Amun-Ra and to restore the supremacy of the royal power may be substantially right (e.g. Redford 1984).

\section{ANALYSIS}

Let us now examine the political situation during Amenhotep IV's reign in the context of the concept of the so-called early totalitarian state, set forth previously by the author. The author first used the concept in connection with the Tahuantinsuyu regime of the ancient Peruvian Incas (Kulmar 2002; see also Kulmar 2003) ${ }^{3}$, later also in determining the system of government of the Qin State in Ancient China (Kulmar 2007; 2011; 2014).

According to the said concept, the following key factors may be discerned about the early totalitarian state (Kulmar 2002: 40-42):

- historical and political reasons for the rise and demise of the system;

- governance and administration;

- economy; 
- social life;

- legal order;

- ideology;

- foreign policy.

These factors have a number of features that I will address in the following analysis. If a regime or a government system matches all the features given below, it represents an ideal case of the early totalitarian state, as the empires of Tahuantinsuyu and Qin very probably did. The less a government system displays the following features, the smaller is the potential degree of totalitarianism in it. Naturally, the more information is available about a particular case, the greater is the likelihood of a correct assessment.

How does Akhenaten's system of government tally with the features of the early totalitarian state based on the available (unfortunately fairly scanty) information about the aforementioned key factors?

\section{Historical and political reasons for the rise and demise of the system}

The existence of a domestic or foreign policy crisis situation; creation of the system in a subjective manner (centred around the person of the sovereign), taking advantage of objective risk factors; a relatively short duration; the demise of the system due either to an inner crisis or foreign pressure.

Amenhotep III bequeathed his son a flourishing state. It is not impossible, however, that Akhenaten sensed various pressures that he considered a threat to the royal power: political pressure by the priesthood and economic pressure (evidently) by the corrupt officialdom. The initiator and implementer of the reforms was Pharaoh Akhenaten himself as he began to restrain the power of the priests and the old court. The reforms lasted a mere decade. The system collapsed due to the emergence of extensive opposition and the failure of a "topdown" revolution. In summary, the case of Akhenaten corresponds to all the features of the factor.

\section{Governance and administration}

The elite's isolation from the people; strictly centralised government; extreme bureaucratisation of the officialdom; maximal control over the spread and consumption of information. 
It may be assumed that the pharaoh's exodus to Akhetaten resulted in his not being fully aware of the actual circumstances, particularly of the failures in the realisation of his reforms. At the same time, the pharaoh had contacts with the common people at the public ceremonies of the cult of Aten. The central government could not function effectively due essentially to dual power between the old and the new court governing from different capitals. There is no reason to regard Akhenaten's officialdom as more bureaucratized than that of Amenhotep III - rather, Akhenaten attempted to curb the old officialdom's power. Assumedly, there were several opposing tendencies in information control: the pharaoh sought to show the people that the cult of Aten was popular and successful; the priests and the conventionalists strove to conceal from the court at Akhetaten noncompliance with the pharaoh's commands; and the court at Akhetaten attempted to hide the actual situation from the pharaoh. As the economic conditions worsened, some regulation of food consumption might have been the case, although there is no evidence to prove that. In summary, the case of Akhenaten matches the features of the factor partly and conditionally.

\section{Economy}

Dominance of public ownership over private ownership or no private ownership; orientation towards a maximally autarkic economy; centralised and rigid planning and control of production and consumption; universal labour conscription; artificially imposed market relations; governmental coercion in the realisation of major projects.

There were several kinds of ownership in Egypt, but private ownership in various forms predominated. Many of the early economies, the Egyptian one included, were rather autarkic by nature, with the role of foreign trade being relatively small and primarily relating to non-necessities. Akhenaten is not known to have attempted to establish anything similar to planned economy. There was no universal obligatory labour conscription, although it might have occurred occasionally in the construction of the capital. As the economic decline escalated, there might have been efforts towards the end of the period at food rationing, but this is mere speculation. Although all through the history of Egypt large masses of people have been forcibly exploited to build labour-intensive facilities, in Akhenaten's case the tendency is manifested in the speedy erection of Aten's temples and, in particular, of the new capital Akhetaten. Consequently, the features of the factor tally with Akhenaten's case only to a small degree. 


\section{Social life}

Orientation towards regulation of the way of life using governmental planning and control mechanisms; restriction of freedom of movement and other personal liberties; segregation against certain social classes; assimilation of certain social groups; systematic suppression of minorities up to total annihilation; governmental demographic control.

Akhenaten is not known to have attempted to interfere in the traditional way of life of the working people or restrict the freedom of movement or other statusrelated freedoms. If any, those who were discriminated were unquestionably public supporters of the cult of Amun-Ra and saboteurs of the reforms, who were probably not a small segment. There is no information about terrorisation of minorities - quite the reverse, Akhenaten proclaimed ethnic and linguistic parity in line with Atenist theology. As far as is known, no population control mechanisms were established in Egypt. In summary, the features of the factor match Akhenaten's case only marginally.

\section{Legal order}

Legislation proceeding from the principle "that which is not permitted is prohibited"; cruel punishments; the dominance of collective responsibility over individual responsibility; persecution of dissenters; existence of a repressive apparatus.

Neither the legal order nor the laws of Egypt are known to have experienced significant changes towards greater stringency under Akhenaten. There is no information concerning collective responsibility being applied in greater measure than before to whole communities for an individual's infringement. However, the pharaoh specifically mandated monitoring of the implementation of his orders regarding the replacement of the officialdom, the restriction of the power of the priests of Amun and the introduction of the cult of Aten, and the abandonment of those of the old gods. There was a respective apparatus to monitor that and to punish the transgressors. Consequently, the case of Akhenaten agrees with the features of the factor partially. 


\section{Ideology}

The philosophy or religion underlying the system has been turned into the official state religion by the special propaganda apparatus; mythologised personality cult; orchestrated mass ceremonies; indoctrinated ethnocentrism; biased educational and cultural policy; censorship of public information and interpretation of history to achieve unified thinking.

Akhenaten's reforms were based on his self-made monotheistic cult of Aten, which acquired the status of state ideology. It was propagated and inculcated by the Atenist priesthood established to that very end. At state level, the cult of Aten was identified with the personality cult of Pharaoh Akhenaten. In honour of Aten and the pharaoh, public rites attended by large crowds were conducted. We cannot speak of any ethnocentrism in that particular period. Dogmatic xenophobia being largely alien to the Egyptians, the New Kingdom period in particular opened up ample opportunities for foreigners (Stadnikov 1998: 23), and Akhenaten even preached the parity of all people before Aten. The pharaoh enjoined systematic propagation of the Atenist doctrine. Censorship of information and history is indicated by actions undertaken to doom the cult of Amun and, in some measure, those of the other gods, to oblivion. Consequently, the case of Akhenaten, with a single exception, tallies fairly fully with the features of this factor.

\section{Foreign policy}

Drive for political hegemony over neighbouring territories; perpetual preparation for aggression and constant willingness to commit aggression; systematic implementation of the state's foreign policy from the position of power and by military means.

With a few exceptions, these features are actually typical of the foreign policy of Ancient Egypt's New Kingdom as a whole, Akhenaten's reign, however, being one of the exceptions. It may even be argued that foreign policy was the least successful area of Akhenaten's government on account of the pharaoh's being poorly informed and constantly immersed in internal affairs. Thus, Akhenaten's case does not agree with the features of the factor. 


\section{CONCLUSIONS}

It appears from the above that Akhenaten's system of government corresponds to the features of the early totalitarian state fully or almost fully only under the factors of historical and political reasons and ideology, whereas in terms of administration and legal order the correspondence is but partial. To a small degree, Akhenaten's reign reveals early totalitarian features in the areas of economy and social life. Only the foreign policy factor shows Akhenaten's system of government void of any early totalitarian features.

In summary, it may be assumed with a high degree of probability that Pharaoh Amenhotep IV alias Akhenaten was heading towards an early totalitarian system of government. The historical and political conditions were favourable, he had a suitable ideology that he vigorously propagated, and he had reached fairly far in creating a corresponding administrative and legal order. However, the economic and social systems are such areas of public life that require more time for cardinal restructuring. It was precisely what Akhenaten did not have his large-scale reform efforts lasted just over a decade.

Accordingly, Akhenaten's experiment may have been one of the earliest known attempts in human history at establishing an early totalitarian state.

\section{ACKNOWLEDGEMENTS}

The article is connected with Estonian Research Foundation Grant no. 6626 and the Estonian Research Funding Project of the Estonian Research Agency no. 500 (PUT500).

\section{NOTES}

1 Also 1364-1347 BC (see Stadnikov 1998: 313) or 1379-1362 BC (see David 2005: 359).

2 Dating based on Clayton 2001: 120.

3 The author first presented the concept in a systematised form in German in 2002. 


\section{REFERENCES}

Assmann, Jan 1975. Ägyptische Hymnen und Gebete. Zürich \& München: Artemis.

Assmann, Jan 1984. Ägypten: Theologie und Frommigkeit einer frühen Hochkultur. Stuttgart: Kohlhammer.

Clayton, Peter A. 2001. Vaaraode kroonika: Vana-Egiptuse valitsejad ja dünastiad valitsemisaegade kaupa. [A Chronicle of Pharaohs: Ancient Egyptian Rulers and Dynasties by Reigns.] Transl. by Kätlin Kaldmaa. Tallinn: Eesti Entsüklopeediakirjastus.

Darnell, John Coleman \& Manassa, Colleen 2007. Tutankhamun's Armies: Battle and Conquest During Ancient Egypt's Late 18th Dynasty. Hoboken, NJ: John Wiley \& Sons.

David, Rosalie 2005. Religioon ja maagia Vana-Egiptuses. [Religion and Magic in Ancient Egypt.] Transl. by Olavi Teppan. Tallinn: Tänapäev.

Dodson, Aidan 2009. Amarna Sunset: Nefertiti, Tutankhamun, Ay, Horemheb, and the Egyptian Counter-Reformation. Cairo \& New York: The American University in Cairo Press.

Doherty, Paul 2004. Tutanhamon: Vaarao mõistatuslik surm. [The Mysterious Death of Tutankhamun.] Transl. by Matti Piirimaa. Tallinn: Kunst.

Grimal, Nicolas A. 1992. A History of Ancient Egypt. Transl. by Ian Shaw. Oxford, UK \& Cambridge, MA: Blackwell.

Hornung, Erik 1978 [1965]. Grundzüge der ägyptischen Geschichte. Darmstadt: Wissenschaftliche Buchgesellschaft.

Hornung, Erik 1983. Conceptions of God in Ancient Egypt: The One and the Many. Transl. by John Baines. London \& Melbourne \& Henley: Routledge.

Hornung, Erik 1992. The Rediscovery of Akhenaten and His Place in Religion. Journal of the American Research Center in Egypt, Vol. 29, pp. 43-49. http://dx.doi. org/10.2307/40000483.

Jacq, Christian 2000. Nofretete ja Ehnaton. [Nefertiti and Akhenaten.] Transl. by Evelin Rand. Tallinn: Kunst.

Kulmar, Tarmo 2002. Die Totalität des Inkareiches und die Rolle der Religion. Trames, Vol. 1, No. 6 (56/51), pp. 38-49.

Kulmar, Tarmo 2003. Totalitarianism and the Role of Religion in the Inca State. Folklore: Electronic Journal of Folklore, Vol. 23, pp. 25-39. http://dx.doi.org/10.7592/ FEJF2003.23.incastate.

Kulmar, Tarmo 2007. Vana-Hiina Qini keisririigi valitsemissüsteemi olemusest. [On the System of Government in Qin Empire in Ancient China.] Mäetagused: Hyperjournal, Vol. 35, pp. 141-153. http://dx.doi.org/10.7592/MT2007.35.kulmar.

Kulmar, Tarmo 2011. Hiina keisririigi valitsemisviisi võimalikust eripärast Sui dünastia ajal (581-618). [On a Possible Characteristic of the Governing System of Chinese Empire during the Time of the Sui Dynasty (581-618 AD).] Mäetagused: Hyperjournal, Vol. 47, pp. 125-134. http://dx.doi.org/10.7592/MT2011.47.kulmar.

Kulmar, Tarmo 2014. On the Nature of the Governing System of the Qin Empire in Ancient China. Folklore: Electronic Journal of Folklore, Vol. 59, pp. 165-178. http://dx.doi.org/10.7592/FEJF2014.59.kulmar. 
Lichtheim, Miriam 1976. Ancient Egyptian Literature. Vol. 2. The New Kingdom. Berkeley \& Los Angeles: University of California Press.

Moran, William L. (ed.) 1992. The Amarna Letters. Baltimore \& London: The Johns Hopkins University Press.

Morenz, Siegfried 1984. Gott und Mensch im alten Ägypten. Leipzig: Koehler \& Amelang.

Murnane, William J. 1995. Texts from the Amarna Period in Egypt. Atlanta, Georgia: Scholars Press.

Redford, Donald B. 1984. Akhenaten: The Heretic King. Princeton: Princeton University Press.

Shafer, Byron E. (ed.) 1997. Temples of Ancient Egypt. Ithaca: Cornell University Press.

Stadnikov, Sergei 1998. Vana-Egiptuse kultuurilugu: Valitud artikleid, tôlkeid ja esseid. [The Cultural History of Ancient Egypt: Selected Articles, Translations and Essays.] Tallinn: Kodutrükk.

Wilkinson, Toby 2013. Vana-Egiptuse tõus ja langus. [The Rise and Fall of Ancient Egypt.] Transl. by Jana Linnart. Tallinn: Tänapäev. 


\title{
HERITAGE ON DEMAND: UNESCO INTANGIBLE CULTURAL HERITAGE INITIATIVE IN CROATIAN CONTEXT
}

\author{
Marijana Hameršak \\ Institute of Ethnology and Folklore Research, Croatia \\ e-mail:marham@ief.hr \\ Iva Pleše \\ Institute of Ethnology and Folklore Research, Croatia \\ e-mail:piva@ief.hr
}

\begin{abstract}
The $\operatorname{article}^{1}$ critically engages with the articulations and manifestations of a UNESCO initiative for the safeguarding of so-called intangible cultural heritage in Croatian context in the first years of the active Croatian implementation of the Convention for the Safeguarding of the Intangible Cultural Heritage (2009-2013). It presents the intersections of a UNESCO initiative with past and present ethnology and folklore research in Croatia. Though one might get the impression (not entirely unfounded) that the project of protecting or safeguarding intangible heritage within the Croatian context first and foremost constitutes a global, imported product, the notion of protecting or safeguarding intangible cultural heritage can also be traced in the history of Croatian ethnology, folkloristics, art conservation, legislation, and folklore festivals production. A strong tendency to transform culture into a slick product can be seen as the main or only 'innovative' aspect of transmitting the old concepts into the contemporary framework of the UNESCO initiative. It seems like this aspect makes it easier for everyone involved - state administration and experts and those to whom a given cultural practice 'belongs' - to ignore 'the side effects' of the UNESCO initiative and the processes of its implementation that are discussed in the article. These side effects, perhaps not so visibly, concern society as a whole, and more directly local communities, as well as our specific professions and disciplines: ethnology and folkloristics.
\end{abstract}

Keywords: Convention for the Safeguarding of the Intangible Cultural Heritage, Croatia, ethnology and folkloristics, heritage production, intangible cultural heritage, UNESCO 


\section{INTRODUCTION: STAGING INTANGIBLE CULTURAL HERITAGE}

'Inherited tradition in counterpoint to modernity' and none other than 'man in the centre of things' were key elements in the ceremony organised to mark Croatia's entry into the European Union, a celebration held in the main square in Zagreb on the night of 30 June $2013 .{ }^{2}$ As stated in the promotional materials prepared for the occasion, the programme was built around 'the values of Croatia's protected cultural property, including the UNESCO Representative List', and strove to emphasise 'Croatia's representative qualities in the areas of music, literature, and science'. In the aforementioned materials the UNESCO Representative List, which grew out of the 2003 Convention for the Safeguarding of Intangible Cultural Heritage, refers to the area of so-called intangible cultural heritage, or what was once known as folklore, traditional immaterial culture, folk art, popular traditions, or some other more or less cognate and similar terms, all of which are closely and probably inextricably linked to ethnology and folkloristics. In previous years, a 'new' intangible cultural heritage of humanity, as it is referred to in the UNESCO Convention, has periodically been added to the List. Annual carnival bell ringers' pageant, the spring procession of Ljelje/Kraljice (Queens), Nijemo kolo, the silent circle dance, and traditional manufacturing of children's wooden toys: these are, to use the terminology of the Convention, some of Croatia's elements which found their place on UNESCO Lists and ultimately in the celebration held to mark Croatia's accession into the European Union, along with their supposed antipodes: modernity and so-called high art. At times these elements were at the forefront of the programme, while at other times their inclusion was almost imperceptible, as in the case of the aforementioned wooden toys which were, together with plastic rakes, given to child actors to 'play' with during the Croatian Radiotelevision Symphony Orchestra and the Symphonic Wind Orchestra of the Croatian Armed Forces' occasional performance of Sunčana polja (Sunny Fields) by Croatian composer Blagoje Bersa.

Whether the celebration was a 'conceptual mixed bag', 'crammed with significant features of Croatian tradition and identity which "must be presented" to the world' (Prnjak 2013), or perhaps 'superbly executed within the set form' (Matasović 2013) is not the issue here. We are not interested in whether the ducats on the Ljelje's costumes were authentic or fake, whether the songs and dances were performed by indigenous bearers of cultural elements or trained members of folklore groups from Zagreb and professional dancers, or whether the performers' costumes were well or poorly reconstructed. The question of whether experts on traditional culture were consulted in the process of select- 
ing and shaping individual performance pieces, or whether the programme included performances that were choreographed long ago and previously staged on numerous occasions, together with descriptions of representative elements of intangible cultural heritage already in circulation (in reality promotional materials from the official website of UNESCO and other similar websites), is not relevant here.

In this context, the abovementioned celebration of Croatia's entry into the EU might provide us with something else. Due to the fact that its content is intertwined with traditional culture, the celebration programme provides us with an opportunity to draw comparisons with the UNESCO initiative for the protection or safeguarding of intangible cultural heritage. The possibilities for drawing comparisons are numerous: one such comparison might focus on the problem of representation as well as selectivity, that is, choosing certain elements for presentation on stage or inclusion on the List over others; additional comparisons might be concerned with the role of authority (the director or folklore expert) and the extent to which the procuring party (state administration) exerts influence on this type of undertaking. Possible comparisons might also focus on means of expressing national pride, presenting a diverse but nonconflicting (polite and spruced-up) national identity, as well as on the role of the idyllic image of dancing peasants in this type of representation.

However, it was something else that prompted us to engage in a discussion of the EU accession ceremony in a text which, adopting a focused local perspective, presents disputes which, to be sure, have parallel articulations the world over. Our main incentive was the issue of whether or not the whole of UNESCO's current project for the protection or safeguarding of intangible cultural heritage - which includes innumerable meetings, conferences, consultations, workshops, reports, feasibility studies, petitions, travels, financing ${ }^{3}-$ is in actuality a performance, a process that ultimately turns select elements into a part of ceremonial celebrations and tourist offers (or maintains the existing status of these elements while adding a brand new UNESCO certificate to them), thus turning them into a 'salvationist framework' (Pofuk 2013) for developing cultural and artistic programmes on stage, utilizing them for presentation purposes, as pretty pictures in catalogues and on websites - in short, reducing them to mere products, despite explicit claims of the abovementioned Convention (cf. UNESCO 2003, Preamble; Art. 1, Art. 2, Art. 11 and Art. 15) that its focus is on the local community and UNESCO's noble intentions to give the community a central position and active part in the process of preserving its own culture in a living context, so that, having been empowered, that same community can take the fate of its own culture into its own hands. Bearing contemporary social tendencies and imperatives in mind, the commodification 
of culture is by no means unexpected, but we would like to point out that it is potentially devastating to the self-perception of communities, individuals, professions and institutions participating in this whole process, to self-perceptions that presuppose a higher degree of complexity and substance.

After all, the main problem with the UNESCO project and other similar projects lies with their side effects, which is to say conflicts, encroachments, and losses, which are already numerous (cf., e.g., Mezey 2007; Mountcastle 2010; Nikočević 2012; Noyes 2006). It is precisely these unsettling (to say the least) side effects - revealed on the margins of the great UNESCO project, and even there by participants or observers speaking in low or hushed voices - that were the incentive for this text, created in collusion with a globally increasing group of texts which are concerned with the side effects and neuralgic points of the UNESCO project and similar endeavours, and address some of the following questions (cf., e.g., Bendix 2009; Bortolotto 2009; Hafstein 2007; Leimgruber 2010; Tsitsishvili 2009): What happens when people begin to perceive their everyday life or part of their lives as heritage? What role does the concept of ownership - a key problem which stems from the Convention implementation but is entirely ignored by that same Convention which makes no attempt to solve it - have within the UNESCO project? What is the role of international political and other organisations, national state administration, and experts in this process? What is the role of the community, and what exactly does the term 'community' refer to? Who is included in the process, who has been overlooked and who, perhaps intentionally, excluded and why? Which practices of inscription onto UNESCO Lists (which seems to be the most important, at times even the only point of the Convention) are perceived by the public? How is culture bought and sold on the political and economic market?

These questions are also essential for understanding the problems which are becoming increasingly prominent in the Croatian context and form the core of following local dilemmas we read about or infer from media reports, and quote or paraphrase in this article. ${ }^{4}$ Is traditional Ojkanje singing a Croatian, Orthodox, Serbian or Balkan tradition? Is Ganga singing a 'privilege' reserved only for inhabitants of its native region in Croatia, or can it also be performed by Croats living abroad? Why does it matter whether one or all groups of Zvončari (described as annual carnival bell ringers' pageant) are inscribed onto the UNESCO List? Can Klapa multipart singing as a stadium attraction be considered a part of the UNESCO heritage, or is this status reserved only for authentic a cappella Klapa multipart singing? Does the inscription of the Sinjska Alka on the List imply its official recognition as the world's oldest chivalric tournament? Is the UNESCO initiative in Croatia in fact the project of a single Minister of Culture? 


\section{CONVENTION FOR THE SAFEGUARDING OF INTANGIBLE CULTURAL HERITAGE}

In previous years, the term 'intangible cultural heritage' has become increasingly present in public discourse in Croatia and elsewhere, in a cultural and scholarly context, but also in the context of tourism and even politics. The reason for this is the aforementioned UNESCO initiative and its key document, the Convention for the Safeguarding of Intangible Cultural Heritage (UNESCO 2003). Among other things, the aim of the Convention is to raise awareness of the importance of intangible cultural heritage, ensure the vitality of its local and national elements, and thus indirectly influence the safeguarding of cultural diversity and human creativity, that is, intercultural dialogue and respect (cf. UNESCO 2003, e.g. Preamble; Art. 1; Art. 2). Responsibility for protecting and safeguarding (though loosely defined) lies primarily with the States Parties, which therefore identify and define elements of intangible culture, create and update Lists, and take necessary steps towards creating and implementing suitable public policies and measures (cf. UNESCO 2003, Art. 11-15). Setting the continuous negotiation process conducted on all levels, and possible modes of granting direct assistance to the States aside (cf. UNESCO 2003, Art. 18-24), it might be said that the very act of awarding certificates or inscribing elements on the two Lists - the Representative List of the Intangible Cultural Heritage of Humanity and the List of Intangible Cultural Heritage in Need of Urgent Safeguarding ${ }^{5}$ - as well as adding them to the Register of Best Safeguarding Practices, constitute virtually the only measures UNESCO itself is obligated to implement.

As has already been noted on numerous occasions, a long, perhaps even several-decades-long negotiation and consulting process which takes place on an international level (cf., e.g., Aikawa 2004) forms the background of the 2003 Convention. The Convention is immediately preceded by the Recommendation on the Safeguarding of Traditional Culture and Folklore (UNESCO 1989), the first official document specifically aimed at safeguarding what will later be termed intangible cultural heritage, as well as the Masterpieces of Oral and Intangible Heritage of Humanity programme, inaugurated in 1998. The Convention itself is sometimes interpreted as an amendment of sorts, but also as the first significant attempt to move away from the influential and much older UNESCO Convention Concerning the Protection of the World Cultural and Natural Heritage (UNESCO 1972), the focus of which was the protection of monuments, groups of buildings or sites, in other words what is nowadays termed tangible heritage. A key critical issue of the 1972 Convention is its Western perception of heritage which has, in the process of implementing the 
Convention, resulted in the fact that the status of 'heritage of humanity' is for the most part granted to urban sites and monuments of high culture, as well as landscapes, the majority of which are located on the northern hemisphere (cf. Kuutma 2013 [2012]: 24). On the other hand, it has often been pointed out that the notion that intangible cultural heritage needs protecting and safeguarding, and consequently the adoption of the 2003 Convention, were strongly influenced by the assumption that globalisation has destructive, even disastrous effects on intangible heritage. At the same time, analyses that would question the adoption of this particular UNESCO Convention from the perspective of UNESCO's wider re-orientation towards promoting, at times even directly serving market interests, in some cases also via partnerships with transnational corporations (cf. Fawcett 2009), are yet to be carried out. Namely, one cannot help feeling that the UNESCO programme is potentially, in some cases also literally, directing culture towards so-called market challenges. By determining, singling out, listing, in other words evaluating culture as representative or endangered elements of intangible culture, for which the responsibility is not delegated to anyone and at the same time is delegated to everyone (humanity, countries, communities, and individuals alike), by its very text, the Convention for the Safeguarding of Intangible Cultural Heritage defines segments of culture which - in the name of various agendas, ranging from strengthening the national tourist or other offer to stimulate the self-sustainability of local communities via similar activities, with a dose of entrepreneurial skill - can, when necessary, be treated as resources and products (cf., e.g., KirshenblattGimblett 2006: 195; Labadi 2013: 141-142). Considering the period in which this process takes place, it seems illusory to expect that the economic coding of yet another sphere of human activity, the culture of 'ordinary' people, will in the long run truly signify something more than the strengthening of a system which values those same people in terms of their necessity to keep the wheels of capital accumulation and circulation turning as effectively as possible. As Walter Leimgruber expressed clearly in the closing remarks of his article on Switzerland and UNESCO Convention:

Should current trends continue, the process triggered by the UNESCO Convention will generate isolated, immobilized, but 'pretty' intangible cultural forms that will become popular tourist attractions. However, these forms have little to do with the lifeways of actual communities. Intangible culture instead will become as decontextualized as the objects of material culture placed behind glass cases, on display in our museums. (Leimgruber 2010: 186) 


\section{THE NOTIONS AND MANIFESTATIONS OF PROTECTING AND SAFEGUARDING IN THE PAST AND PRESENT CROATIAN CONTEXT}

Croatia ratified the UNESCO Convention for the Safeguarding of Intangible Cultural Heritage already in 2005 (cf. Zakon 2005), thus adding to the number of countries necessary for the Convention to enter into force in 2006. The promptness that characterises Croatia's acceptance of the Convention is one of many indications of just how willing its state administration - which has with that express purpose in mind put entire administrative and expert-scientific machineries in motion - is to take such a step.

Though one might get the impression (not entirely unfounded) that the project of protecting or safeguarding intangible heritage within the Croatian context first and foremost constitutes a global, imported product, the notion of protecting or safeguarding intangible cultural heritage can also be traced in the history of Croatian ethnology, folkloristics, art conservation, and legislation. Namely, contributions (in the second part of the twentieth century also prompted by international organisations and bodies) dealing with various levels of 'protecting' (from descriptions and regulations, through inventory-making to conservation protection) what is nowadays termed intangible cultural heritage, stemmed from those precise areas.

In the Croatian context, intangible culture has been codified since the adoption of the 1999 Law on the Protection and Safeguarding of Cultural Property. Still in force today, this Law also defines 'immaterial forms and instances of man's spiritual creation in the past' (Zakon 1999, Art. 2), or 'intangible cultural property' (Zakon 1999, Art. 9) as a special type of cultural property. What is more, one of its mechanisms - the Register of Cultural Property of the Republic of Croatia (or rather the segment of the Register which refers to intangible cultural property) - has taken on the role of a national inventory of intangible cultural heritage, an instrument set out in the UNESCO Convention (UNESCO 2003, Art. 12), and nowadays functions as the entry point for Croatian nominations to UNESCO Lists. Namely, entry into the Register is a prerequisite for being nominated to one of these Lists. Paradoxically enough, legal definitions require the Register to include intangible cultural property which is (with the exception of linguistic phenomena) explicitly oriented towards the traditional, folklore and folk, which is at odds with the wider definition provided by UNESCO. In other words, Croatia can nominate such elements of intangible culture to UNESCO Lists that are manifested as 'language, dialects, speech, and toponyms, along with all kinds of oral literature; folklore production in the 
areas of music, dance, traditions, games, rituals, and social practices, along with other traditional folk values; traditional skills and craftsmanship' (Zakon 1999, Art. 9), while the much wider definition set forth in the UNESCO Convention describes intangible culture as '(a) oral traditions and expressions, including language as a vehicle of the intangible cultural heritage; (b) performing arts; (c) social practices, rituals and festive events; (d) knowledge and practices concerning nature and the universe; (e) traditional craftsmanship' (UNESCO 2003, Art. 2, § 2). ${ }^{6}$

Although the term 'intangible cultural property' was introduced into legislative regulation in 1999, the means of safeguarding and protecting intangible cultural heritage had been discussed in the Croatian Ethnological Society more than three decades earlier. As elsewhere, it was the part of, as Laurajane Smith calls it, Authorised Heritage Discourse of a time or professional discourse 'involved in the legitimization and regulation of historical and cultural narratives, and the work of that these narratives do in maintaining or negotiating certain societal values and the hierarchies that these underpin' (Smith 2012). Reports on the work of the Croatian Ethnological Society thus contain information about the establishment of the Ethnographic Commission for Museum and Conservation Work in 1962 (Milićević 2009: 16) which was, among other things, charged with the task of proposing alterations and amendments to the 1960 Law on the Protection of Monuments of Culture, 'with reference to intangible traditional heritage' (Škrbić Alempijević \& Oroz 2009: 70). That the issue of protecting intangible aspects of traditional culture was of particular interest to individual members of the Commission - conservators and museologists - is seen in the fact that two years later an independent Commission for Detecting Possibilities for Protecting Intangible Culture was formed (Škrbić Alempijević \& Oroz 2009: 70). ${ }^{7}$

On a somewhat similar trail is also the manuscript of a lecture, given by Croatian ethnologist Dunja Rihtman-Auguštin (1982), at that time acting as representative of the Yugoslav Government in the UNESCO Committee of Governmental Experts (Rihtman-Auguštin 1984: 27). Though pursuing other research interests in her scholarly work, Rihtman-Auguštin gave the aforementioned lecture at a conference dedicated to issues of folklore protection in the Balkan countries. In the lecture, Rihtman-Auguštin presented the Yugoslav and wider professional community with the necessity for and means of protecting folklore, a topic that had also been discussed in Paris the previous year, at the meeting of said UNESCO Committee in which she herself took part. Protection is presented as a process which has to bring together two perspectives: an ethnological-folkloristic perspective, which includes the processes of safeguarding, collecting, organizing, and archiving, publishing, studying, and 
applying, but also a legal perspective concerned with protection from 'inappropriate uses of folklore creations', commercialization, and other forms of exploitation (Rihtman-Auguštin 1982: 2, 5). Furthermore, Rihtman-Auguštin suggests that a 'register of institutes, bureaus, museums, public and private collections', in other words, 'a database of traditional culture and folklore' (Rihtman-Auguštin 1982: 7-8) be formed, first on the level of individual republics of the former Federal Republic of Yugoslavia, and then on the level of the Republic as a whole, with the tendency of expanding, to include the entire Balkan area. The Croatian Ethnological Society and the Institute of Folklore Research (nowadays: the Institute of Ethnology and Folklore Research) began work on 'a database of folklore and traditional culture in Croatia and Yugoslavia' (Rihtman-Auguštin 1984: 23), which resulted in a register containing more than 100 institutions in Croatia, dedicated to collecting and safeguarding materials related to traditional culture and folklore (s.n. 1986; cf. also Škrbić Alempijević \& Oroz 2009: 75). Plans for incorporating 'the information system of materials regarding traditional culture and folklore into the international system implemented by UNESCO', networking with institutions with similar databases, and continuing with the process of analysing folklore materials with the aim of incorporating them into the aforementioned system (Rihtman-Auguštin 1984: 23) were not realised. The project led to the publication of Institutions that Collect and Preserve Materials on Traditional Culture and Folklore in the Federal Republic of Croatia (s.n. 1986), as well as archival materials which include completed forms from individual Yugoslav institutions and are kept in the Archives of the Institute of Ethnology and Folklore Research in Zagreb (Turčin 1982-1986).

Efforts aimed at creating a database that might be linked to the documentation of (traditional) culture as one of many important activities within Croatian ethnology and folkloristics in general, and activities developed independently from UNESCO and its initiatives, may be subsumed under the term of so-called salvation ethnology, anthropology or ethnography. The term refers to specific initial stages of a given discipline or disciplines, marked (both in Croatia and elsewhere) by the idea of salvaging cultures that are visibly disappearing, and primarily under the influence of a wider combination of processes which are often described as modernization, urbanization, industrialization, etc. Within the Croatian context, the notion of salvation (though not expressed by such an explicit syntagm) can be traced back to the end of the nineteenth century and the first, subsequently more systematically developed, attempts to describe and document folk life and folk traditions. ${ }^{8}$ The points, methods, and means of approaching traditional culture, as well as the choice of elements that need to be salvaged - documented, described, but perhaps also truly preserved changed over time and were differentiated, based on their theoretical starting 
points and areas of ethnological and folkloristic activities. However, regardless of these changes, as well as the changing role and status of the salvation project within Croatian ethnology and folkloristics, the idea of salvation has never completely died out and might thus be designated not only as one which marks the beginning of scholarly investigations of (traditional) culture, but also as one which, in a way, presents a permanent feature of our disciplines. With regard to all this, UNESCO's salvation mission (as expected) also fell on fertile ground in Croatia. Even more so, since the Convention for the Safeguarding of Intangible Cultural Heritage which, in truth, is often interpreted or presented as a deviation from the type of salvation based on listing and documenting, lists those same activities among key measures for protection and safeguarding (cf. UNESCO 2003, Art. 2, § 3; Art. 12; Art. 16-17).

In present-day Croatia, the salvation attitude towards culture, especially traditional culture, is perhaps most prominent in various forms of public presentations of folklore, from the UNESCO initiative to folklore festivals, the oldest systematically organised activities of this type. Presenting folklore on stage, similar to presenting folklore on one of the Lists, is regularly (though not always and not exclusively) defined as a form of safeguarding, protecting - in a word, salvaging. Furthermore, this type of salvation is often initiated, promised, undertaken, supervised and at times (if only for promotional purposes) adopted by political, state, international or party agendas and administrations.

There are other similarities between folklore festivals and the UNESCO program. Seeing that they provide a vivid summary of the key points of UNESCO's initiative (especially its implementation), we will discuss these similarities in more detail below.

UNESCO Lists and programs for intangible cultural heritage create a public image of folklore, heritage, tradition, and similar categories, even of subject matters and aims of ethnology and folkloristics, in the same way that folklore festivals have been doing for decades, and continue to do today.

The UNESCO initiative insists on a wide range of practices and living traditions, which serves to emphasize its departure from previous initiatives of this type, including folklore festivals, often aimed at building national culture via performance on stage or some other form of reviving elements that have been recognized as representatives of earlier, traditional culture. However, a more detailed comparison between UNESCO and folklore festivals reveals that differences between them are those of degree rather than type. Although, as has already been noted, the concept of intangible cultural heritage, as defined in the Convention, is wider than the one promoted by folklore festivals (as it includes practices such as craftsmanship, which are only marginally included in folklore festivals in Croatia or even excluded altogether, as well as practices of so-called 
high or urban culture), a significant number of Croatian cultural property inscribed on UNESCO Lists belongs to musical or dance forms (e.g. Bećarac singing and playing, Ojkanje singing, Nijemo kolo - silent circle dance), as well as customary practices (e.g. Ljelje, Zvončari), which have earlier, some even a long time ago, been established as representative within folklore festivals. It should be noted, for instance, that Ojkanje, perhaps the 'most exotic' Croatian element found on UNESCO Lists, attracted possibly the most attention of both experts and the general public, even before World War II (cf. Ceribašić 2003: 153-156). From a historical perspective, the festivals defined a canon that has permeated collective images of folk culture and the legal definition of cultural property, and then went on to shape Croatia's participation in the UNESCO program and Lists.

In sum, what is often nominated to the Lists is previously canonized folklore, while the aforementioned proclaimed distance and break are reduced to little more than ornamental and rudimentary additions to concepts previously established by folklore festivals. In a turn of events, the UNESCO program itself was the theme of the 2010 International Folklore Festival held in Zagreb, Croatia; without too many difficulties and in agreement with its previous practices, this festival transformed elements from the Lists into elements performed on stage, thus reinforcing the impression that the only thing that the UNESCO project brings to the table is a new packaging for things that are familiar and have already been seen. All this leads us to conclude that it would be more appropriate to consider the link between folklore festivals and UNESCO in terms of continuity, that is, expansion, upgrading of existing concepts and practices, as well as re-orientation towards documentation practices, workshops etc., rather than radical departures and twists.

Even the insistence of the UNESCO Convention on living practices, and communities and individuals connected to them, is not very far removed from the focus on so-called authentic folklore which has (with occasional departures or attempts at departures) functioned as the central axis of folklore festivals in Croatia since the 1930s (cf., e.g., Ceribašić 2003; Sremac 2010). Namely, the concept of so-called authentic folklore also assumes that communities present their own, though most frequently once living, collective practices on stage. Within the framework of this concept, village folklore groups perform repertoires that are seen as a characteristic expression of their tradition, which initially signified a radical departure from previous practices copied from urban environments, which is to say practices of village choirs performing authorial compositions based on folk songs. Introducing the concept of so-called authentic folklore also shows signs of opening up at least towards previously living practices, as well as of lending a certain degree of legitimacy to participants in these practices 
(Ceribašić 2003: 187), which are, as has already been mentioned, the levels that UNESCO also insists on. However, after the initial momentum, a performance and genre canon of folklore festivals was established, which at times blocked even explicit attempts to present a wider range of practices rooted in contemporary and everyday life; at the same time lending legitimacy to performers as social subjects with disruptive potential has gradually been downgraded to the sphere of amateurism devoid of wider social pretensions. Along with the canon itself, its effect was transferred into the UNESCO initiative, which is thus, just like the folklore festivals before it, primarily realized as a representational and staged project, at times even with economic potential, usually miles away from living practices or life in communities that UNESCO itself swears by.

In addition to sharing the repertoires and values of folklore festivals, the UNESCO project is similar to them on the level of mechanisms, as well as the goals it is based on. In addition to being among the prominent aims of the Convention (cf. UNESCO 2003, Preamble; Art. 1), safeguarding heritage and encouraging intercultural dialogue are long-standing goals of the International Folklore Festival in Zagreb, as well as numerous similar manifestations (cf. Ceribašić 2008: 9-12). In relation to mechanisms, it is important to point out that national lists of intangible cultural heritage, at least in the Croatian context, function as a kind of antechamber, the first round of selection for nominations to one of the UNESCO Lists, in the same way that the program for the main folklore festival has for decades been selected from the programs of smallerscale festivals (regional, local, preparatory, and others). As has already been noted for folklore festivals (cf. Zebec 2008: 274), Lists also, even in cases when they are not defined as competitive, or even when they, as is the case with the UNESCO Lists, explicitly distance themselves from this status, have strong innate competitive mechanisms. Furthermore, Lists, like folklore festivals, are formed on the basis of external, expert selection, which adds to their competitive dimension.

The final level of similarities between UNESCO initiatives and folklore festivals, which we would like to point out here, refers to participation of ethnologists and folklorists in their realisation. Since the 1930s, Croatian folklorists and ethnologists have taken part in advisory, appraisal or organisational bodies of folklore festivals and, depending on the specific social circumstances, have had a variable, but, taking a long-term view, crucial role both in selecting individual performances and shaping the concept and orientations of festivals in general. They were given a similar role in the process of implementing the UNESCO project in Croatia. But while direct preparation of communities for participation was rare at the inception of folklore festivals (Ceribašić 2003: 81), Croatian nominations to UNESCO Lists were characterised by precisely 
this type of expert involvement. Thus the process within the Croatian context was developed top to bottom: namely, experts were in charge of preparing the necessary application materials, even though the UNESCO Convention is often hailed as the one to make the crucial step towards including the community. Setting aside the question of what community is, what its boundaries are, and who speaks for it, let us stick to the obvious, which is to say the fact that this proclaimed novum of the UNESCO initiative within the Croatian context has manifested itself only within its declarative and decorative dimensions. This is further suggested by the tendency to (at least in the Croatian context) inscribe so-called genres (see, e.g., Zebec 2013), phenomena, and practices on the Lists, which are primarily defined in relation to accepted expert concepts and ambitions of the state administration, and not just concrete practices that individual communities perceive as their own and as specific. Nowadays one might hear that communities themselves tend to demonstrate more and more initiative to nominate elements which they perceive as part of their tradition to one of the UNESCO Lists. However, the question is to what extent the way in which the elaboration might be formulated, i.e., the context in which these elements will be placed as a result of the concept of genres and other administrative-expert frameworks of the nomination, fits the communities' initiative.

The problems of a top-down approach which, among other things, leads to the substitution of local names with generic ones, while practices are grouped into genres which, to an extent, robs the community of its right to its own perspective, are illustrated by the example of Ganga singing and Ojkanje singing. Namely, the Register of Cultural Property of the Republic of Croatia ${ }^{9}$ includes a property called Ganga singing, associated with the 'area of Imotski and Vrgoračka Krajina', which is not under 'UNESCO protection'. ${ }^{10}$ At the same time, as suggested by materials available on the official UNESCO website, ${ }^{11}$ as well as by public reactions, ${ }^{12}$ this form of musical expression is part of the cultural property called Ojkanje singing, which has been inscribed on the UNESCO List of Intangible Cultural Heritage in Need of Urgent Protection. To be sure, the materials for nomination to the UNESCO List do not explicitly use the term Ganga singing, but the description of the musical expression and the sites mentioned suggest that it is also (at least in some of its many variants) included in the nomination. Leaving numerous questions aside, including the issue of who has the right to represent the Croatian Gang ${ }^{13}$ which has been at the centre of public debates in Croatia for some time, as well as the question of why the elaboration of the nomination of Ojkanje singing makes no explicit mention of Ganga singing, let us mention only a few, perhaps exhausting but certainly symptomatic, 'technical problems' of these lists and registers. For instance, the name of the element, "Musical Expression Ojkanje from the Area of the Dalmatian Hinterland", found 
in the Croatian Register, leads one to erroneously conclude that this cultural property is linked to 'the Dalmatian hinterland' alone, when it is in fact - according to that same register and the brief description it includes - also linked to several other Croatian regions. Moreover, the Dalmatian hinterland itself has been included in the register as a separate region (Dalmatian hinterland), with two geographical sites entered separately, as if they did not belong to that same area (although they do). On the other hand, materials available on the official UNESCO website mention the same two sites as part of the Dalmatian hinterland. What is more, the description of that element on the UNESCO website now also includes some areas which are not found in the description of that cultural asset in the Croatian Register. In addition to all this, Ganga singing has been entered into the Register separately and put in a category called "Knowledge and Skills", while Ojkanje singing is found under the heading of "Customs, Rituals and Festivals". In short, in addition to revealing a relaxed situational manner, bureaucratic understatements and contradictions, this mess also (and more importantly) points to the drifting created by the notion that culture can be segmented into intangible cultural property that can be treated just like any other property.

\section{SCHOLARLY PRODUCTION OF HERITAGE VS. SCHOLARLY PRODUCTION OF KNOWLEDGE}

As has already been mentioned, ethnologists and folklorists in Croatia have, from the very beginning, taken part in various activities related to the acceptance and implementation of the Convention for the Safeguarding of Intangible Cultural Heritage by acting, for instance, as members of national and international bodies, developing methods for implementing the Convention, studying intangible cultural practices - potential candidates for inscription onto one of the UNESCO Lists, writing or reviewing nominations for inscriptions on the Lists, etc. Convention-related practice, by which we primarily mean efforts to inscribe elements of intangible cultural heritage onto UNESCO Lists, has for years been quite prominent in Croatia. Since 2009, a total of fourteen cultural elements have been inscribed on two UNESCO Lists: as many as seven in 2009, three in 2010, two in 2011, and one in both 2012 and 2013. In contrast, the number of texts produced in that same period (2009-2013), which provide a critical perspective and view the processes of implementing the Convention from a scholarly perspective, is not very big. With the exception of contributions which make passing, short, descriptive references to the Convention, or assume 
the perspective of application, ${ }^{14}$ we are dealing with a handful of ethnological and folkloristic texts.

One of these texts, written by Naila Ceribašić, was initially published in 2009 under the title "A New Wave of Promoting National Heritage: UNESCO's 'Convention for the Safeguarding of Intangible Cultural Heritage' and its Implementation". Published in Bosnia and Herzegovina in a collection of essays primarily intended for musicologists, this is the first scholarly paper by a Croatian researcher entirely dedicated to the UNESCO initiative. The second text"Culture or Heritage? The Problem of Intangibility" by Lidija Nikočević - was published in the journal of the Croatian Ethnological Society in 2012. In 2010, the Croatian journal Studia ethnologica Croatica published another scholarly article about the Convention: written by Amy Mountcastle, the paper deals with the implementation of the UNESCO program in a different geographical and cultural context. In 2013, a text by Tvrtko Zebec provided an outline of the processes and conflicts of the implementation of the Convention in Croatia from the perspective of participation. Finally, in the same year, all the articles listed above were included in a separate collection entitled Proizvodnja baštine (The Production of Heritage) and edited by Marijana Hameršak, Iva Pleše, and Ana-Marija Vukušić.

As opposed to the rather modest and mostly sceptical domestic scholarly production on the subject of the UNESCO initiative, the public (media) discourse is marked by celebratory overtones and the practices of counting results. From the numerous media reports which have appeared in previous years and which deal with the subject of inscriptions onto the UNESCO List of Intangible Cultural Heritage, one interview published online might be taken as a synecdoche: while discussing Croatian elements of intangible culture, the Deputy of the Croatian Minister of Culture used the following phrase for emphasis: 'Number four in the world, number one in Europe', referring to the fact that (at that moment, of course), compared to other European countries, Croatia had the largest number of intangible cultural elements on UNESCO Lists, and ranked fourth in the world (just after China, Japan, and Korea), based on the same criteria. ${ }^{15}$

If we were to adopt this dominant (and tiresome) public discourse with regard to the UNESCO initiative and decided to 'count' the results, we might, taking as indicators the number of Croatian entries on the UNESCO Lists on the one hand and the number of scientific publications providing criticism or reflection on the Convention and its implementation on the other, get a ratio in which the second number would be several times smaller than the first one. To be sure, this 'sportsmanlike' manner of 'calculating' results is not an appropriate way to view scientific production. In addition, what is under discussion here are 'elements' - entries on the Lists on the one hand, and scientific papers 
on the other - which should be carefully entered into the same equation, not least because the number of properties inscribed on the Lists can be precisely determined, which is not the case with the number of texts that will be accepted as scholarly and critical contributions. Also, scientific musings on any topic cannot even remotely keep up with the variety of practices taking place 'in the field', even the field of UNESCO and implementation. However, the fact that UNESCO has primarily been viewed as a platform for what is tentatively called applied science, and only sporadically as a current social phenomenon, which is to say a subject of scientific interest, provokes our interest. Studying the social dimensions of the UNESCO Convention would also certainly include questions about communities' reactions and expectations, as well as the concrete effects and possible predictions related to some of the nominations, etc. These are questions which undoubtedly require attention, but to which at this moment and within the Croatian context we are unable to provide answers based on specific ethnographic research, as this type of research, at the moment of writing this article, has yet to be conducted.

Meanwhile, an increasing number of researchers in ethnology, folkloristics, and related disciplines are taking part in activities related to the implementation and promotion of the UNESCO Convention. We can only speculate about the reasons behind the disproportion that exists between the level of participation in these activities and that of scientific reflection on the whole process. Commitment to activities focused on inscription onto the UNESCO Lists is hardly surprising, considering the long tradition of applied ethnology and folkloristics in Croatia, which has already been discussed. Perhaps what we are dealing with here is simply the need to do something for the communities that ethnologists and folklorists study as part of their research, and, on the other hand, to contribute to the recognizable quality of intangible culture, and consequently the subject matters of ethnology and folkloristics, in a wider social context - in short, to achieve application of knowledge produced in the scientific process in society, for the benefit of the people the researchers study, and with the presupposed belief in the positive outcomes of the Convention's implementation, despite indications of the contrary. Commitment to this type of involvement - ultimately in the sense of time one has at one's disposal, as well as the different approaches required by (once again, with some qualifications) implementation on the one hand and reflection on the other - may influence the production of scientific writing as well. Furthermore, the social climate in the past years has provided additional stimulus for this type of involvement, since research is nowadays first and foremost expected to be oriented towards producing useful and applicable knowledge, usefulness being very narrowly 
defined in this context, often simply as a state of being connected with the economy, which, in the concrete case of the Convention for the Safeguarding of Cultural Heritage, probably signifies a link with lucrative culture tourism. From the perspective of state administration, applicability can probably also be achieved in the realm of promotional activities designed to supposedly increase the reputation of a national state within its own borders and the world.

This last remark brings us back to the story of the ceremony marking Croatia's entry into the European Union, a celebration which clearly demonstrates the tendency to transform culture into a slick product, which at the same time makes it easier for everyone involved - state administration and experts and those to whom a given cultural practice 'belongs' - to ignore the Potemkin's villages of UNESCO's (or some other) initiatives, as well as to close their eyes to the side effects of the processes discussed here, side effects which, perhaps less visibly, concern society as a whole, and more directly local communities, as well as our specific disciplines and professions. Speaking of our disciplines, and within the context of the aforementioned demands which the media and especially administrations place before researchers and research in our disciplines, the disproportion between routine application and critical reflection in the case of UNESCO brings to mind reflections and anxieties about the future in which ad hoc routine work becomes the key point for evaluating the work of ethnologists and folklorists, while the key dimension of our work as researchers, the one we associate with the value of research, re-examination and criticism, is made redundant amidst a whirlwind of demands and adjustments, becoming an unnecessary ballast which should be abandoned. It is our belief that these values will not disappear, but the question remains within the contexts of which institutions will they be developed and nourished. Speaking of culture, its creative and critical potentials will certainly not disappear, but unfortunately, they are likely to be primarily developed outside, rather than within UNESCO's and other corresponding models for the production of heritage.

Translated by Nada Kujundžić 


\section{NOTES}

1 A somewhat different variant of this text was originally published in Croatian, as an introduction to Proizvodnja baštine: kritičke studije o nematerijalnoj kulturi (The Production of Heritage: Critical Studies on Intangible Culture) (edited by Marijana Hameršak, Iva Pleše, and Ana-Marija Vukušić), a collection of essays published in 2013 by the Institute of Ethnology and Folklore Research in Zagreb.

${ }^{2}$ Here and in the following sentence we quote materials presented at the press conference held on the eve of the celebration of Croatia's entry into the European Union; available at http://www.scribd.com/doc/149148240/HR-EU-prezentacija-za-pressicu-130621, last accessed on 6 November 2018.

3 Cf. UNESCO web page at http://www.unesco.org/culture/ich/, last accessed on 6 November 2018.

4 The questions quoted or paraphrased here are taken from the various and widely distributed Croatian media.

5 See https://ich.unesco.org/en/lists, last accessed on 13 November 2018.

6 Due to the aforementioned discrepancy between the internal laws of Croatia and those of the Convention, some future activist initiative for Croatia to nominate, let us say, the 40-hour work week, public health or free education to one of the UNESCO Lists, would additionally be doomed to 'fail' and be exposed to public scepticism, perhaps even academic cynicism. Naturally, we are not harbouring under the illusion that UNESCO would welcome this type of initiative; we are merely trying to point out that, formally speaking, it would be somewhat harder to disqualify it than it would within the Croatian context, seeing that the 40-hour work week, public health services and free education might be described as 'practices, representations ... that communities, groups and, in some cases, individuals recognize as part of their cultural heritage' (UNESCO 2003, Art. $2, \S 1$ ), which is how UNESCO defines intangible cultural heritage.

7 As far as we know, the first published lecture explaining that the status of monument of culture (and its accompanying principles of preservation) should be granted to 'intangible transmitted heritage' also dates from this period. Published in 1969, the text in question is the work of ethnologist and conservationist Beata GotthardiPavlovsky.

${ }^{8}$ Cf., e.g., a detailed questionnaire about folk life (Osnova za sabiranje i proučavanje grade o narodnom životu 'The Basis for Collecting and Studying Material on Folk Life') composed by the founder of Croatian ethnology Antun Radić; the Call for Collecting Croatian Folk Songs (Poziv za sabiranje hrvatskih narodnih pjesama) issued by the key national institution Matica Hrvatska. Reprints of both texts were published in the 2010 issue of the journal Zbornik za narodni život $i$ običaje (Journal for Folk Life and Customs, volume 55).

9 Cf. the search engine for cultural property of the Republic of Croatia, http://www. min-kulture.hr/default.aspx?id=6212, last accessed on 6 November 2018 . 
${ }^{10}$ See http://www.min-kulture.hr/default.aspx?id=6212, last accessed on 6 November 2018.

${ }^{11} \mathrm{See}$ http://www.unesco.org/culture/ich/doc/download.php?versionID=05434, last accessed on 6 November 2018.

${ }^{12}$ See, e.g., Jendrić (2010), Lucić (2012) and Tomić (2010).

${ }^{13}$ See, e.g., Dragan \& Ćosić (2012), and Lucić (2012).

${ }^{14}$ To illustrate this point, we refer the reader to a few of these texts, for instance, Ceribašić (2009), Jelinčić (2008), Jelinčić \& Žuvela Bušnja (2008), Kalapoš Gašparac (2009), Nikočević (2008), Rudan (2012), Vitez (2007), Zebec (2009, 2012).

${ }^{15}$ Considering the dominant media (and not only media) discourse, it seems important to point out here that the number of properties inscribed on the UNESCO Lists is by no means a measure of the value of culture of a given country. More than anything else, it reveals how well-prepared the state administration and diplomacy are, and to what degree the international community is open towards that country's aspirations. Furthermore, it should be noted that these are not definitive, immutable lists (although some countries have held 'first places' on them for quite some time), but lists that are expanded each year with the addition of new elements. However, it would seem that the UNESCO project also faces limitations typical for similar initiatives and that nowadays it is much more difficult to achieve inscription on one of the Lists than it was at the very beginning. There are numerous possible reasons for this: from a lack of administrative capacities to the belief that the initiative has already been publicly 'recognised'.

\section{REFERENCES}

Aikawa, Noriko 2004. An Historical Overview of the Preparation of the UNESCO International Convention for the Safeguarding of the Intangible Cultural Heritage. Museum International, Vol. 56, No. 1-2, pp. 137-149. https://doi.org/10.1111/ j.1350-0775.2004.00468.x.

Bendix, Regina 2009. Inheritances: Possession, Ownership, and Responsibility. Traditiones, Vol. 38, No. 2, pp. 181-199. DOI: 10.3986/Traditio2009380212.

Bortolotto, Chiara 2009. The Giant Cola Cola in Gravina. Intangible Cultural Heritage, Property, and Territory between Unesco Discourse and Local Heritage Practice. Ethnologia Europaea, Vol. 39, No. 2, pp. 81-94.

Ceribašić, Naila 2003. Hrvatsko, seljačko, starinsko i domaće: Povijest i etnografija jaune prakse narodne glazbe u Hrvatskoj. [Croatian, Peasant, Old and Local: History and Ethnography of the Public Practice of Folk Music in Croatia.] Zagreb: Institut za etnologiju i folkloristiku. 
Ceribašić, Naila 2008. Festivalski okviri folklornih tradicija: Primjer Medunarodne smotre folklora. [Festival Frames of Folklore Traditions: The Example of International Folklore Festival.] In: Zorica Vitez \& Aleksandra Muraj (eds.) Predstavljanje tradicijske kulture na sceni $i$ u medijima. [Presentation of Traditional Culture on the Stage and in the Media.] Zagreb: Institut za etnologiju i folkloristiku \& Hrvatsko etnološko društvo, pp. 7-20.

Ceribašić, Naila 2009. Prilog produkciji baštine: Obnova pojanja u perojskih Crnogoraca. [A Contribution to Heritage Production: Revival of Pojanje among Peroj's Montenegrins.] In: Naila Ceribašić \& Ljiljana Marks (eds.) Izazov tradicijske culture: Svečani zbornik za Zoricu Vitez. [The Challenge of Traditional Culture. Essays in Honour of Zorica Vitez.] Zagreb: Institut za etnologiju i folkloristiku, pp. 309-325.

Dragan, Gordana \& Ćosić, Braco 2012. Imotsku gangu u Parizu pjevat će - Hercegovci!? [People from Hercegovina Will Sing Imotski's Ganga!?]. Slobodna Dalmacija, 25 October. Available at https://www.slobodnadalmacija.hr/scena/mozaik/ clanak/id/183427/imotsku-gangu-u-parizu-pjevat-ce--hercegovci, last accessed on 12 November 2018.

Fawcett, Michelle 2009. The Market for Ethics: Culture and the Neoliberal Turn at UNESCO. Diss. (PhD Thesis). New York University. Available at https://search. proquest.com/docview/304957352/abstract, last accessed on 7 November 2018.

Gotthardi-Pavlovsky, Beata 1969. Folklorna građa i pitanje njene zaštite. [Folklore Materials and Their Protection.] Makedonski folklor, Vol. 3/4, pp. 397-406.

Hafstein, Valdimar Tr. 2007. Claiming Culture: Intangible Heritage Inc., Folklore@, Traditional Knowledge ${ }^{\mathrm{TM}}$. In: Dorothee Hemme \& Markus Tauschek \& Regina Bendix (eds.) Prädikat "HERITAGE": Wertschöpfungen aus kulturellen Ressourcen. Berlin: LIT Verlag, pp. 75-100.

Hameršak, Marijana \& Pleše, Iva \& Vukušić, Ana-Marija (eds.) 2013. Proizvodnja baštine: Kritičke studije o nematerijalnoj kulturi. [Heritage Production: Critical Studies in Intangible Culture.] Zagreb: Institut za etnologiju i folkloristiku.

Jelinčić, Daniela Angelina 2008. Abeceda kulturnog turizma. [ABC of Cultural Tourism.] Zagreb: Meandarmedia/Meandar.

Jelinčić, Daniela Angelina \& Žuvela Bušnja, Ana 2008. Uloga medija u predstavljanju, mijenjanju i kreiranju tradicije. [The Role of the Media in Presenting, Changing and Creating the Tradition.] In: Aleksandra Muraj \& Zorica Vitez (eds.) Predstavljanje tradicijske kulture na sceni $i$ u medijima. [Presentation of Traditional Culture on the Stage and in the Media.] Zagreb: Institut za etnologiju i folkloristiku \& Hrvatsko etnološko društvo, pp. 51-63.

Jendrić, Dorotea 2010. Unesco zaštitio alku, licitarsko srce i "ojkante" della Croazia. [Unesco Protected Alka, Licitarsko Srce and "ojkante" della Croazia]. Večernji list, 17 November. Available at https://www.vecernji.hr/kultura/unesco-zastitio-alkulicitarsko-srce-i-ojkante-della-croazia-216904, last accessed on 12 November 2018.

Kalapoš Gašparac, Sanja 2009. Tradicija na pladnju turizma. [Tradition as Served to Tourism.] In: Naila Ceribašić \& Ljiljana Marks (eds.) Izazov tradicijske culture: Svečani zbornik za Zoricu Vitez. [The Challenge of Traditional Culture: Essays in Honour of Zorica Vitez.] Zagreb: Institut za etnologiju i folkloristiku, pp. 327-335. 
Kirshenblatt-Gimblett, Barbara 2006. World Heritage and Cultural Economics. In: Ivan Karp \& Corinne A. Kratz \& Lynn Szwaja \& Tomás Ybarra-Frausto \& Gustav Buntinx \& Barbara Kirshenblatt-Gimblett \& Ciraj Rassool (eds.) Museum Frictions: Public Cultures / Global Transformations. Durham and London: Duke University Press, pp. 161-202.

Kuutma, Kristin 2013 [2012]. Between Arbitration and Engineering: Concepts and Contingencies in the Shaping of Heritage Regimes. In: Regina F. Bendix \& Aditya Eggert \& Arnika Peselmann (eds.) Heritage Regimes and the State. Göttingen: Universitätsverlag Göttingen, pp. 21-36. Available at https://univerlag.unigoettingen.de/handle/3/isbn-978-3-86395-122-1, last accessed on 7 November 2018.

Labadi, Sophia 2013. UNESCO, Cultural Heritage, and Outstanding Universal Value: Value-based Analyses of the World Heritage and Intangible Cultural Heritage Conventions. Lanham \& New York \& Toronto \& Plymouth, UK: Rowman and Littlefield.

Leimgruber, Walter 2010. Switzerland and the UNESCO Convention on Intangible Cultural Heritage. Journal of Folklore Research, Vol. 47, No. 1-2, pp. 161-196. http://dx.doi.org/10.2979/jfr.2010.47.1-2.161.

Lucić, Predrag 2012. Posljednja ganga u Parizu. [The Last Ganga in Paris.] Novilist.hr, 25 October. Available at http://www.novilist.hr/Komentari/Kolumne/TrafikaPredraga-Lucica/Posljednja-ganga-u-Parizu, last accessed on 7 November 2018.

Matasović, Trpimir 2013. San europske noći. [European Night's Dream.] Zarez.hr, 4 July. Available at http://www.zarez.hr/clanci/san-europske-noci, last accessed on 7 November 2018.

Mezey, Naomi 2007. The Paradoxes of Cultural Property. Columbia Law Review, Vol. 107, No. 8, pp. 2004-2046. Available at https://www.jstor.org/stable/i40002232, last accessed on 7 November 2018.

Milićević, Josip 2009 [1979]. Pretisak teksta o prvih dvadeset godina rada Društva. [Reprint of the Text about the First Twenty Years of Croatian Ethnological Society.] In: Tihana Rubić \& Nevena Škrbić Alempijević \& Željka Jelavić \& Željka Petrović Osmak (eds.) 50 godina Hrvatskoga etnološkog društva (1959.-2009.) [Fifty Years of Croatian Ethnological Society (1959-2009).] Zagreb: Hrvatsko etnološko društvo, pp. 13-32.

Mountcastle, Amy 2010. Safeguarding Intangible Cultural Heritage and the Inevitability of Loss: A Tibetan Example. Studia ethnologica Croatica, Vol. 22, No. 1, pp. 339 359.

Nikočević, Lidija 2008. Zaštita i predstavljanje nematerijalne kulturne baštine. [Protection and Presentation of Intangible Cultural Heritage.] In: Aleksandra Muraj \& Zorica Vitez (eds.) Predstavljanje tradicijske kulture na sceni i u medijima. [Presentation of Traditional Culture on the Stage and in the Media.] Zagreb: Institut za etnologiju i folkloristiku \& Hrvatsko etnološko društvo, pp. 145-151.

Nikočević, Lidija 2012. Culture or Heritage? The Problem of Intangibility. Etnološka tribina, Vol. 42, No. 35, pp. 57-70. Available at https://hrcak.srce.hr/index. php?show=clanak\&id_clanak_jezik=138565, last accessed on 13 November 2018. 
Noyes, Dorothy 2006. The Judgement of Solomon: Global Protections for Tradition and the Problem of Community Ownership. Cultural Analysis, Vol. 5, pp. 27-56. Available at https://pdfs.semanticscholar.org/fac7/55f436ffd03cbc83d2f737d5d2 59dcc112b7.pdf, last accessed on 7 November 2018.

Pofuk, Branimir 2013. Dora Ruždjak Podolski režira svečanost ulaska Hrvatske u EU. [Dora Ruždjak Podolski Is the Director of the Ceremony of Croatia's Accession to EU.] Večernji list, 23 June. Available at http://www.vecernji.hr/vijesti/doraruzdjak-podolski-rezira-svecanost-ulaska-hrvatske-u-eu-clanak-573660, last accessed on 7 November 2018.

Prnjak, Hrvoje 2013. Novogodišnji doček članstva u Europskoj uniji. [New Year's Celebration of Membership in European Union.] Slobodna Dalmacija, 2 July. http://www.slobodnadalmacija.hr/Reflektor/tabid/92/articleType/ArticleView/ articleId/214632/Default.aspx, no longer available.

Rihtman-Auguštin, Dunja 1982. Zaštita folklore: Akcija i problemi. UNESCO - Pariz 1982. [Folklore Protection: Action and Problems. UNESCO - Paris 1982.] IEF ms. 1611.

Rihtman-Auguštin, Dunja 1984. Trideset i pet godina rada Zavoda za istraživanje folklora. [Thirty-Five Years of Department for Folklore Research.] Narodna umjetnost, Vol. 21, pp. 11-33. Available at https:/hrcak.srce.hr/45637, last accessed on 7 November 2018.

Rudan, Evelina 2012. Verbalni folklor i njegova (re)prezentacija. [Verbal Folklore and Its (Re)presentation.] In: Mira Muhoberac (ed.) Međunarodni znanstveni interdisciplinarni simpozij "Hrvatska folklorna $i$ etnografska baština u svjetlu dubrovačke, sujetske i turističke sadašnjosti - FEB 2011”. Zbornik radova. [International Interdisciplinary Scholarly Conference of Croatian Folklore and Ethnographic Heritage in the Light of the Dubrovnik, World and Tourist Presentthe FEB 2011]. Dubrovnik: Folklorni ansambl Linđo, pp. 509-519.

Smith, Laurajane 2012. Discourses of Heritage: Implications for Archaeological Community Practice. Nuevo Mundo Mundos Nuevos / New World New Worlds. Questions du temps présent. DOI: 10.4000/nuevomundo.64148.

s. n. [Turčin, Vesna] 1986. Institucije koje skupljaju i čuvaju građu o tradicijskoj kulturi i folkloru u SR Hrvatskoj. Izvanredni svezak, knj. 8. [Institutions Which Collect and Archive Traditional Culture and Folklore Materials. Special Volume, 8.] Zagreb: Zavod za istraživanje folklora.

Škrbić Alempijević, Nevena \& Oroz, Tomislav 2009. Mijene etnoloških pristupa i metoda. [Transformations of Approaches and Methods in Ethnology.] In: Tihana Rubić \& Nevena Škrbić Alempijević \& Željka Jelavić \& Željka Petrović Osmak (eds.) 50 godina Hrvatskoga etnološkog društva (1959.-2009.) [Fifty Years of Croatian Ethnological Society (1959-2009).] Zagreb: Hrvatsko etnološko društvo, pp. 65-87. Available at http://www.hrvatskoetnoloskodrustvo.hr/wp-content/ uploads/2012/11/Spomenica-HED-a.pdf, last accessed on 9 November 2018.

Sremac, Stjepan 2010. Povijest i praksa scenske primjene folklornog plesa u Hrvata: Između društvene $i$ kulturne potrebe, politike, kulturnog $i$ nacionalnog identiteta. [The History and Practice of Application of the Traditional Dance on the Stage among Croats: Between Social and Cultural Necessity, Politics, Cultural and National Identity.] Zagreb: Institut za etnologiju i folkloristiku. 
Tsitsishvili, Nino 2009. National Ideologies in the Era of Global Fusions: Georgian Polyphonic Song as a UNESCO-Sanctioned Masterpiece of Intangible Heritage. Music \& Politics, Vol. 3, No. 1. http://dx.doi.org/10.3998/mp.9460447.0003.104.

Tomić, Ante 2010. Ooo-o-o-o! Ooo-o-o-o-oooj! Jutarnji list, 20 November. Available at http://www.jutarnji.hr/ante-tomic--ooo-o-o-oooj-/905432/, last accessed on 9 November 2018.

Turčin, Vesna 1982-1986. Dokumentacijska građa uz projekt "Regionalni registar institucija koje skupljaju i čuvaju građu o tradicijskoj kulturi i folkloru u SFR Jugoslaviji", 1982-1986. [Documentary Materials of the Project "Regional Register of Institutions That Collect and Archive Traditional Culture and Folklore Materials in SFR Yugoslavia", 1982-1986.] IEF ms. 2038.

UNESCO 1972 = Convention Concerning the Protection of the World Cultural and Natural Heritage. Available at http://whc.unesco.org/en/conventiontext/, last accessed on 2 November 2018.

UNESCO 1989 = Recommendation on the Safeguarding of Traditional Culture and Folklore. Available at http://portal.unesco.org/en/ev.php-URL_ID=13141\&URL_ DO=DO_TOPIC\&URL_SECTION=201.html, last accessed on 2 November 2018.

UNESCO 2003 = Convention for the Safeguarding of the Intangible Cultural Heritage. Available at https://ich.unesco.org/en/convention, last accessed on 13 November 2018.

Vitez, Zorica 2007. Legenda o Picokima u svjetlu globalne i nacionalne (kulturne) politike. [The Legend of the Picoks in the Light of Global and National (Cultural) Policy.] Narodna umjetnost, Vol. 44, No. 2, pp. 11-25. Available at https://hrcak. srce.hr/23263, last accessed on 9 November 2018.

Zakon 1999 = Zakon o zaštiti $i$ očuvanju kulturnih dobara. [Act on Protection and Safeguarding of Cultural Goods.] Available at http://narodne-novine.nn.hr/clanci/ sluzbeni/271022.html, last accessed on 9 November 2018.

Zakon 2005 = Zakon o potvrdivanju Konvencije o zaštiti nematerijalne kulturne baštine. [Act on the Ratification of the Convention for the Safeguarding of the Intangible Cultural Heritage.] Available at http://narodne-novine.nn.hr/clanci/ medunarodni/327387.html, last accessed on 9 November 2018.

Zebec, Tvrtko 2008. Izazovi primijenjene folkloristike i etnologije. [Challenges of Applied Folklore Studies and Ethnology.] In: Zorica Vitez \& Aleksandra Muraj (eds.) Predstavljanje tradicijske kulture na sceni $i$ u medijima. [Presentation of Traditional Culture on the Stage and in the Media.] Zagreb: Institut za etnologiju i folkloristiku \& Hrvatsko etnološko društvo, pp. 271-286.

Zebec, Tvrtko 2012. Kultura - tradicija - baština - turizam: Dubrovnik i Hrvatska u dvadeset i prvome stoljeću. [Culture - Tradition - Heritage - Tourism: Dubrovnik and Croatia in the 21st Century.] In: Mira Muhoberac (ed.) Medunarodni znanstveni interdisciplinarni simpozij "Hrvatska folklorna i etnografska baština u svjetlu dubrovačke, svjetske i turističke sadašnjosti-FEB 2011”. Zbornik radova. [International Interdisciplinary Scholarly Conference of Croatian Folklore and Ethnographic Heritage in the Light of the Dubrovnik, World and Tourist Presentthe FEB 2011.] Dubrovnik: Folklorni ansambl Linđo, pp. 503-507. 
Zebec, Tvrtko 2013. Etnolog u svijetu baštine: Hrvatska nematerijalna kultura u 21. stoljeću. [Ethnologist in the World of Heritage: Croatian Intangible Cultural Heritage in the 21st Century.] In: Jasna Čapo \& Valentina Gulin Zrnić (eds.) Hrvatska svakodnevica: Etnografije vremena i prostora. [Croatian Everyday Life: Ethnographies of Time and Space.] Zagreb: Institut za etnologiju i folkloristiku, pp. 173-195. 


\section{IN MEMORIAM}

\section{BARRE TOELKEN}

\subsubsection{5 - 09.11.2018}

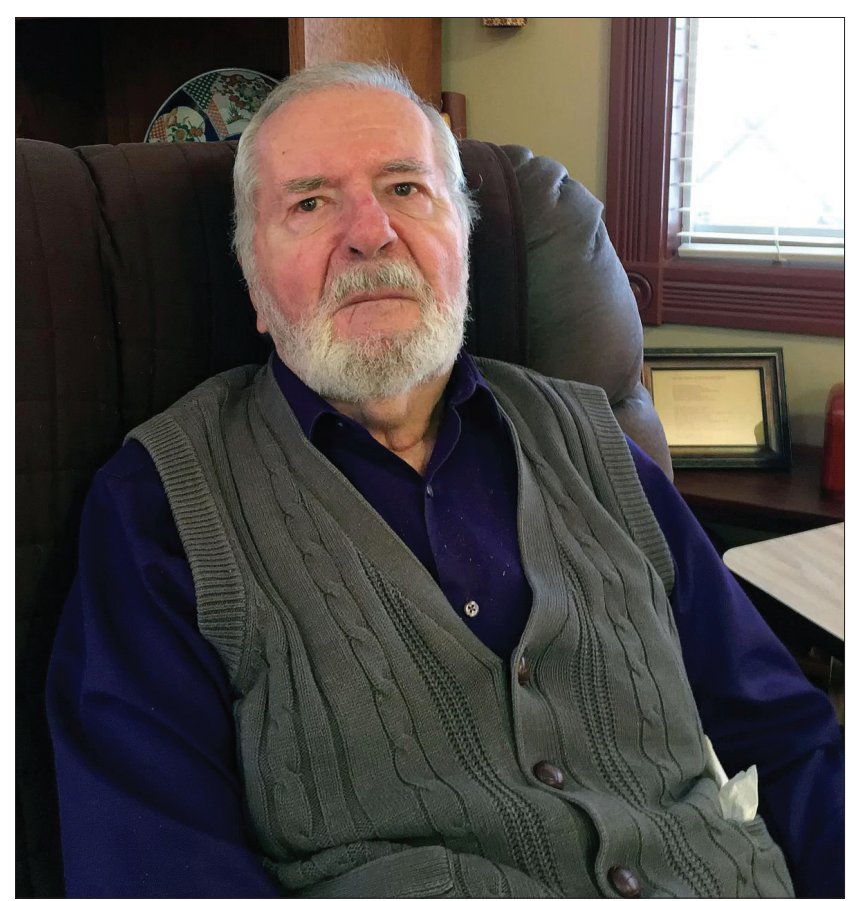

Barre Toelken, a distinguished and colorful scholar in American folkloristics, passed away on November 9. Toelken was widely known as a recorder of Navajo folklore and healing traditions, researcher into ballads and Japanese folklore, captivating lecturer, and author of many books.

John Barre Toelken was born in Massachusetts and grew up in an ordinary family. He studied natural resources at Utah State University, yet after spending two years on the Navajo Reservation, he continued his studies at the graduate school of the University of Oregon, where he received his $\mathrm{PhD}$ in medieval literature in 1964. The professorship in the English language (1966-1985) was followed by the professorship in the English language and history at Utah State University. He was also director of the folklore program at this university in 1985-2002. During his career he was president of the American Folklore Society (AFS), and editor of the journal published by the AFS as well as the journal Western Folklore. The annual conference of the American Folklore Society in Miami in 2016 awarded him with the lifework prize. 
Barre Toelken's passion and openness both in research and in his personal life made him exceptional. He was a groundbreaker and innovator of folkloristics, who never hesitated to make his own decisions and stand up for his own worldview. As a passionate traveler and collector of folklore, he recorded different traditions. Toelken was accepted into the Yellowmans' Navajo family and showed great respect for his American Indian kin. His gesture to return to his Navajo family his entire collection of tape recordings he had made during scores of years provoked heated argument; however, he opined it was the least he could do for a living culture. Toelken married a Japanese-American, Midori (Miiko), in 1957, although interracial marriages were forbidden by law until the 1960s. Barre and Miiko Toelken had six children.

Barre Toelken's classical works include The Dynamics of Folklore; Morning Dew and Roses: Nuance, Metaphor and Meaning in Folksongs; Ghosts and the Japanese: Cultural Experience in Japanese Death Legends; The Anguish of Snails: Native American Folklore in the West. A characteristic specimen of his fieldwork classics is "The Yellowman Tapes, 1996-1997", which was published in the Journal of American Folklore in 1998, and in which he recounts his decision to return the tapes to the Yelloman family (see https:// digitalcommons.usu.edu/cgi/viewcontent.cgi?article=1711\&context=english_facpub).

Mare Kõiva

You can listen to Barre Toelken singing athttps://www.youtube.com/watch?v=cgqF8OjFaRU. 


\section{COMPARATIVE MYTHOLOGY ON THE EARTH AND HUMANKIND: PAST, PRESENT AND FUTURE}

The 12th Conference of the International Association on Comparative Mythology (IACM) under the general title Myths of the Earth and Humankind: Ecology and the End of the World took place in Sendai, Japan, on June 1-4, 2018. The conference was hosted by Tohoku University, with Professor Hitoshi Yamada as chair of the organizing committee. These annual IACM meetings started at the founding conference in Bejing, China, in 2006, and were followed by eleven symposiums organized in various countries. Professor of Sanskrit Michael Witzel (Harvard University) is the president of the IACM (for more information on the Association see http://www.compmyth.org).

In spite of the long journey that had to be undertaken by the participants to come to Japan, the forum turned out to be representative: 36 scholars from 14 countries delivered their papers during three and a half days. We had the great opportunity to listen to all the presentations, because there were no parallel sessions - a rare occasion nowadays. The program was compiled so logically that in our review we will follow the order of the papers.

The opening of the conference and the first lectures were given in the ancient Komyoji Temple, in a special atmosphere of a Buddhist shrine, calm, harmonious, and beautiful. For the first time in our academic life, all the participants, including us, had to be barefoot during the whole day of the seminars. Since we specialize in the Slavic ethnology and linguistics and have never been lecturing in temples, it was a very impressive experience - most probably not only for us.

Other sessions were held in the modern and high-tech rooms of Tohoku University, on the premises of the Tohoku Center for Creativity.

As usual at the conferences of the IACM, all the reports were interesting and innovative. This time it was partly due to the variety of aspects of the announced theme, including catastrophes, ecology and the end of the world, but certainly also by the variety of world mythologies, presented in the reports: European (Slavic, Baltic, German), Indian, Japanese, Mayan, Chinese, Indo-Pacific, and African. The major topic was linked to the notions of the elements of nature, such as water, fire, earth, and air, their qualities and ontological forms (lakes, mountains, etc.), activity (flood, earthquake) and the calamities they can cause. Death and funeral rites, childbirth and creation, as well as royal kinship were also analyzed. The data used for research varied from myths and narratives to folklore and rituals, fiction, poetry, and films. Scholars of comparative mythology and epics, and cultural and literary studies as well as folklorists, anthropologists, linguists, translators, ecologists, and biologists discussed in detail the theme of catastrophes from various points of view.

The first session, New Perspectives in Comparative Mythology, consisted of four speakers, who discussed the most important issues touched upon at the conference. 
Yuri Berezkin (St. Petersburg, Russia), a prominent scholar of comparative mythology and narratives, the author and compiler of the widely known analytical index of the mythological folklore motives in different regions of the world and their thematic categorization (ca. 55,000 texts, ca. 950 traditions and ca. 2500 motifs, i.e. narrative episodes and descriptions of mythological ideas; see www.ruthenia.ru/folklore/berezkin/), spoke on the topic The Southeast Asian Homeland of the Cosmologies. He argued that the emergence of particular ideas and stories was not a uniform process stimulated by patterns intrinsic to human mind or by ecological conditions, but rather a creative development under the regional specificity and historical chance. According to the index, a vast majority of cosmological tales are concentrated in the Greater Southeast Asia (from Middle India to Southern China). The American parallels for many of these tales provide an argument in favor of their emergence in 17,000-20,000 BP at least. This area was the homeland of the world's most complex and elaborated cosmological cycle. The mapping of the variants and the comparison of their details suggest that the transcontinental spread of many other most important myths related to the origin of the world and people (like the earth-diver, the swan-maiden, etc.) had also begun in the Indo-Pacific region.

Michael Witzel (Harvard, USA) gave a lecture titled A Different Version of the Flood Myth. He argued, contrary to the universal and well known myth, according to which the flood derived from the ocean rising, rain, emptying a bowl, etc., that it arose from an emptied lake or pond. This version is known in several areas, from Khotan (in Xinjiang), Kashmir, the Kathmandu Valley and tribal areas in Nepal. Witzel suggests that perhaps this idea of the origin of the flood can be extended to northern China and (in a fairy tale) to Japan.

Steve Farmer (Palo Alto, USA) in his report Myths of Global Destruction in the Early Anthropocene: Neurobiological, Historical, and Ecological Perspectives traced the cross-cultural origins and growth of extreme "correlative" or "fractal" cosmologies linked to complex man-the-microcosm schemes that at times did help mitigate human destruction of the environment. The paper first discussed the origins of these systems in brainculture networks dependent on evolving modes of literate technologies over thousands of years. It then discussed how the increasing abandonment of these holistic models in the 20th century, reflecting the growing complexities of molecular biology and genetics, coincided with what has been referred to as a "great acceleration" in anthropogenic influences on the planet in the last few decades.

Makoto Yokomichi (Kyoto, Japan) read his paper titled Comparative Mythology of the Brothers Grimm and Their Successors. He alluded to the pioneering works on comparative mythology and folklore of the 19th century, especially developed by Max Müller and Jacob and Wilhelm Grimm. Wilhelm Grimm's "Grimms' Fairy Tales", in spite of its world fame, has not been studied enough. Few researchers know that the edition has valuable notes on comparative mythology. The ideas of the Grimms, Wilhelm Mannhardt, and Johannes Bolte are still very significant for the modern studies of the world mythology.

In the section Mythology of the Americas and East and South-East Asia six reports were presented.

Martín Cuitzeo Domínguez Nuñez (Mexico City, Mexico) delivered his paper The Fire of Sky: A Myth from two Indigenous Groups in Northwest Mexico. The myth of Pa 
Ipai and Koal, two ethnic groups with endangered languages, tells a story about the fire of the sky and its relation to the end of the world and the local notion of time. The myth was analyzed through an approach which combines anthropology with semiotics, in order to understand the connection between its symbolism and the Pa Ipai and Koal cultural context.

Lucie Vinšová (Brno, Czech Republic) in her report Humans as the Keepers of the Universe: Water Cycle in Native Colombian Cosmology provided insight into mythological and cosmological motifs as represented in the beliefs and rituals of Misak and Nasa tribes (the communities of the mountainous areas of south-west Colombia), linked to the importance of water (creation myths, water creatures, the birth of legendary chieftains, etc.). She also showed the way the importance of water is manifested in religious and healing rituals, and the original role of human beings as keepers of this life-giving force.

The presentation by Štěpan Kuchlei (Brno, Czech Republic) dealt with Cambodian and Thai myths that are closely linked to Tonlé Sap Lake and to the ancient traditions of the south-east Asian notion of kingship, strongly intertwined with the history, religious rituals, and agricultural cycle of the whole area. An old Khmer story claims that the origin of Boeung Tonlé Sap, Cambodia's Great Lake, is a result of the disappearance of a rich, marvelous city. This city was - because of its ruler's unjust deeds - sinking deeper and deeper, until the area became a lake, Tonlé Sap. Out of the lake a huge buffalo garlanded with lotus flowers emerged from the depths, carrying on its back the most sacred object of the sunken city, a Buddha statue made of emerald. The myth has it that many years later the statue was found floating in the river by the Thai town of Chiang Rai. Until today, the emerald Buddha represents one of the most sacred objects of the Thai royal treasury.

Bong-Youl Kim (Gyeongju, South Korea) in The Narratives of Odysseus and Seok Talhae, a Study in Maritime Culture and the Dialectic of Enlightenment: On the Origin of Rationality examined maritime culture and the birth of rationality by comparing the mythic narratives of Odysseus and Seok Talhae. According to the theory of the "dialectic of enlightenment", as expounded by Horkheimer and Adorno, rationality enabled advanced science and technology, but it also caused a civilizational crisis. Furthermore, this dialectic has reached its peak in our world. The two epic heroes represent enlightenment and rationality, since both have broken out from the mythical veil of older cultures. This rational worldview can be traced back to the sea peoples, who first appeared in the 13th century BC. Both Odysseus and Seok Talhae use cunning and deceit to win. But unlike Odysseus, Seok Talhae became a king by respecting the pre-existing order. Thus, that myth suggests a possible transformation to a civilization of coexistence and peace.

Michal Schwarz (Brno, Czech Republic) read a paper titled Mountains and Monsoons: Difficult Ways to Harmonize the Spirits. Mountains and waters as wild and dangerous, especially in mutual interactions, play an important role in Asian mythologies. The paper, besides describing different natural conditions along the coast of East Asia and comparing corresponding religious or mythological explanations of regular vs. irregular monsoons in connection with mountains, analyzed the motif of mountains and the role of mountain spirits from the perspective of ritual practices described in research papers as well as in Vietnamese, Korean, and Chinese folktales. The types of mythological narratives about mountains may be explained from the point of view of lowlands as the most common habitat of Homo sapiens. 
Emma Zhang (Hong Kong) in her paper No End in Sight presented to the participants the Chinese myth of Nezha, solidified and popularized in the 16th century. Nezha is the only Chinese mythological figure who actively rebels against and attempts to murder his father. Unlike many patricidal figures from Greek myths, such as Cronos, Zeus or Oedipus, who successfully overthrow the reigns of their fathers and establish a new world order, Nezha's desperate rebellion ultimately ends in the defeat of the son. Dr. Zhang argued that the Nezha myth gives an insight into the phenomenon, arguing that although there have been countless rebellions throughout Chinese history against despotic emperors and rulers, the system of a centralized patriarchal hierarchy is as stable as ever in modern-day China, in spite of the change of ideologies.

This paper served as a good transition to the next session, Mythology and Modernity. Sachie Kiyokawa (Kobe, Japan) dedicated a paper to the influence of "Northern Mythology" on Victorian Britain. As an example of a Victorian poet fascinated by the idea that European nations initially shared the same myths, and in the course of medieval adaptations to each nation's culture they became separated from each other, the oeuvre of William Morris was chosen. Young Morris was an ardent reader of B. Thorpe, so he even retold Thorpe's translation of a Danish myth, as a short story titled "Lindenborg Pool" (1856). To Thorpe's version Morris added discernibly Gothic details, and a timeless narrator gazing at the past. Through comparing Thorpe's and Morris's narratives and how northern myths were accepted in Victorian Britain, the contributor revealed the significance of World Mythology, not only in structural analysis but in regard to cultural effects, especially poetry and prose.

This aspect of research was continued by Seán Martin (Edinburgh, UK) in Facing Rebirth: Apocalyptic Themes in the Fiction of David Lindsay, discussing Scottish metaphysical author David Lindsay (1876-1945). This author appropriated apocalyptic myths from the Norse tradition into his novels "A Voyage to Arcturus" (1920) and "Devil's Tor" (1932). The scholar examined how Lindsay used Norse material in "Arcturus" for his own purposes, reflecting apocalyptic undercurrents in post-Great War culture. "Devil's Tor" can be read as a literal prophecy of apocalypse, being published eight months before Hitler came to power.

The paper by Louise Milne (Edinburgh, UK) also touched upon the theme of apocalypse: Apocalyptic Myth and Dreams in the Films of Andrei Tarkovsky. The paper explored the relations between dreams, apocalypse and myth in Tarkovsky's cinema, considering its sources in dream-cultures of the Cold War. The films "Ivan's Childhood" (USSR, 1962), "Stalker" (USSR, 1979), "Nostalghia" (Italy, 1983), and "The Sacrifice" (Sweden, 1986) were examined. Milne argued that, in creating these filmic narratives and sequences, Tarkovsky updated mythic themes, images, texts, and ideas, to interpret and express the collective traumatic experience of World War II and the Cold War for his own and later generations.

Ideological issues and the notion of creation, contrasting with the apocalyptic themes, were in the focus of Aleksandar Bošković's (Belgrade, Serbia) paper Classic Maya Myths and Politics: Creation and Destruction of the World. He shed light on the sources and assumptions that led to the beliefs that ancient Mayan (and Mesoamerican in general) ideologies and worldviews were largely influenced by the idea of periodic creation and destruction of the world. A rich body of material confirms this idea. 
Marcin Lisiecki (Torun, Poland) in his paper The Power of Unbelievable Stories: Motifs of the End of the World and Human Extinction in Polish Urban Legends aimed to describe Polish urban legends about the end of the word. The paper dealt with contemporary popular culture - urban legends, which the scholar considered to be a neglected field. He discussed theoretical questions, such as whether urban legends belong to the contemporary mythology, whether they continue the motifs of folk tales, whether they are unique popular stories, etc. The contributor also spoke about the sources, meanings, and goals of retelling urban legends in Polish tradition.

This paper provoked a discussion on how thoroughly urban legends are discussed in other countries where the tradition of keen attention paid to those texts is long and fruitful, and has resulted in many publications.

Takeshi Kimura (Tsukuba, Japan) in his report Myths of Automata: From Talos, Pygmalion, Golem to Robot attempted to compare the ancient mythic narratives of technology and the contemporary secular narratives of robotics, so as to examine what mythic narratives are. Old myths of technology and automata and the contemporary social concern raise, as Kimura said, several interesting questions regarding an imaginative reason to generate mythic narratives, an asymmetrical gender-sexual relationship (Galatea / Pygmalion and female robot Sophia / robotics engineer David Hanson) and a technological and magical relationship (Talos and Golem / Programmed Robots and Powered Class / Ordinary Class). To follow Levi-Strauss, our contemporary societies, which have "never been modern" according to Latour, are continuing to form mythic and bricolaged narratives. If we follow Eliade, contemporary secular narratives are nothing but camouflaged "sacred narratives". Thus the scholar sees the development of archaic myths as a permanent process.

The section Indo-European Mythologies with 10 lectures altogether was open by Václav Blažek and Michal Schwarz (Brno, Czech Republic) who presented their paper Divine Beings Connected with Earth in Indo-European Traditions and Beyond. They drew attention to the divine names connected with "earth" in various Indo-European traditions: Iranian (Avestan Zam-), Anatolian (Hittite tēkan), Greek (Taĩa, $\Delta \eta \mu \eta \dot{\imath \eta} \rho$, XӨ่́v, gen. $\mathrm{X}^{\theta}$ ovós), Italic (Latin tellūs, -ūris, Tellūmo, -ōnis), Celtic (Middle Welsh Dôn), Germanic (Icelandic Jǫð), Baltic (Latvian Zemes māte, Lithuanian *Žemepatis, *Žemina) and Tocharian (Tocharian B kem-ñäkte). The authors concluded that there probably was a common theonym "Earth" in Proto-Indo-European, appearing as various derivatives of *dhghem- "earth" in the daughter language branches.

Joseph Harris (Harvard, USA) spoke on the topic Some Uses of Apocalypse: Instrumentalizing Ragnarök. After describing the famous Old Norse apocalypse, worldending "Ragnarök", and briefly locating it in the eschatology of world mythologies, the paper centered on human uses of such an apocalypse in medieval Scandinavia. Since Ragnarök is "the affair of the gods" (its variant "the twilight of the gods"), the question about what place it has in the life of mere humans and how they utilize the myth sounds actual. The most interesting testimony comes from Old Norse-Icelandic poetry and from continental Scandinavian runic inscriptions, but a verbally related Old Frisian text was also included.

Kazuo Matsumura (Tokyo, Japan) in Comparative Epic Literature was studying the common motifs in the four old epics: Greek "Iliad" and "Odyssey", and Indian 
"Mahābhārata" and "Rāmayana". As was shown, the combinations of motifs in the four epics are as follows:

- the Iliad: earth's burden, kidnapped wife, fight;

- the Odyssey: voyage across the ocean;

- the Mahābhārata: earth's burden, fight;

- the Rāmāyana: kidnapped wife, voyage across the ocean, fight.

So a reconstruction of the Proto-Indo-European epic can be assumed: heroes make a voyage across water to recapture a kidnapped wife. The two sides fight and this results in a massacre. This massacre is the intended plan of the chief god to alleviate the earth's burden. In Greece and India tradition has divided the original epic into two, although the combination of the motifs is different.

Lisa Fujiwara (Tokyo, Japan) read a paper titled St. Augustine's Attitude toward the Styx in Crisis Situations. One of the famous myths about death is that once people die, they descend to the underworld, cross the Styx, and finally go to the world of death. In this myth, burial is a prerequisite for crossing the Styx. St. Augustine was acquainted with this myth as described in Aeneid (VI: 327-8). When the Roman Empire was invaded and ravaged by the vandals in the 5th century, many Romans were killed and most of them were left unburied due to the chaotic situation. Augustine mentioned this catastrophe and noted how to deal with those unburied in the City of God and in the Care for the Dead. He went as far as to say in the Care for the Dead that Christianity must reject the myths that forbid the unburied to cross the Styx. Apparently he regarded Virgil's lines depicting the burial as a requirement for crossing the Styx as false and rejected the very myth.

Signe Cohen (Columbia, USA) in her paper End Games: Dice, Board Games, and the Apocalypse in Indo-European Mythology showed (while Albert Einstein famously claimed that God does not play dice) that Indo-European gods, goddesses, mythical kings, and heroes do play both dice and other games, with the fate of the universe at stake. She analyzed Vedic and later Sanskrit texts about dice play, kingship, and the ages of the world. She also investigated the Old Norse texts about board games, dice, kings, and Ragnarök, and Celtic sources relating board games to kingship, decay, and cosmic regeneration. She argued that games, divinity, kingship, and apocalypse are so intertwined in Indo-European myths that we may postulate that these connections are Proto-Indo-European in origin.

Nataliya Yanchevskaya (Princeton, USA) in the paper At the End of Times compared a series of eschatological myths and folktales of different Indo-European traditions, concentrating on the South Asian, Iranian, Greek, Scandinavian, Germanic, and Slavic materials. Having analyzed the common motifs, she attempted to reconstruct characteristic features of the Indo-European eschatological proto-myth. A special attention was paid to the Indo-European deities of time, fate, and death and their role in eschatology as well as to the concept of Cosmic cycles and "ages" of the universe.

Joanna Jurewicz (Warsaw, Poland) in Death, Mahabharata, and Storytelling analyzed the problem of death in the Mahābhārata, using the frames of oral storytelling and the concept of literary viewpoints. This approach is adequate in the interpretation of the philosophy of ancient India which preserved its tradition in oral form, and this fact could motivate abstract thinking of the composers. Jurewicz contributed to a better understanding of the situation of a bounded and liberated man. In the former case, the 
terrifying experience of death can be seen as the ontological situation when the story becomes real for its listener. In the latter, the construal of a new viewpoint from the absolute level and its fusion with the empirical one results (besides the radical ontological and cognitive transformation of the agents) in ironical attitude, expressed in the description of Kṛna as prahasann iva, when he begins to explain to Arjuna the sense of death from the absolute viewpoint.

Boris Oguibénine (Strasbourg, France) in his Earth in the Rigveda focused on lexical elements as markers of mythological motifs in the Rigveda. By analyzing multiple items meaning "earth" and their contexts, he attempted to explain the construction of semantically varying narratives that gave birth to Vedic myths about Earth and, second, used comparative (primarily, Indo-European) data to find the specific features of these myths.

Eijirō Dōyama (Osaka, Japan) discussed the topic of How to Be a Hero in Ancient India: Unusual Birth and Abandonment of Children. He argued that miraculous life stories are characteristic of heroes in numerous myths worldwide (an unusual conception, e.g., by god-human intermarriage, parthenogenesis; an unusual delivery, e.g., from the mother's side, from an egg; abandonment after birth, e.g., in a river, on a mountain; being raised by a non-human; slaying a monster, e.g., a dragon, serpent, and so on), but they differ from culture to culture. Two motifs - unusual birth or conception, and abandonment of newborn children - are characteristic of the heroic myth in ancient India. The paper investigated how these two motifs are expressed in Vedic texts, as well as in Mahābhārata and Purānas. Close observation revealed that many heroes can speak when they are still in the womb, and a newborn child is almost always abandoned by his biological mother. By analyzing these and other characteristic patterns in terms of mythological symbolism, Dōyama explained what ancient Indians thought heroes were like and what they thought the requirements were for a child to be a hero.

Sunil Parab (Dehradun, India) in his Literary and Observational Study on Disease as a Medium for End of the World by Gods focused on diseases and mythical stories associated with the emergence of diseases. Interestingly though, in many cultures diseases are not considered as acts of the devil but rather as punishment by the gods. The Vedic literature associates gods with the emergence of diseases and also focuses on the way to eliminate them. The Indian epic mythology shows Daksha Yagna as responsible for the emergence of multiple diseases. Indian folklore is full of regional references as well as remedies associated with diseases. The paper also compared the observations from Indian mythology with mythical stories associated with disease as a medium for the end of the world across different mythical cultures. In the conclusion the mythical emergences of diseases accepted by Indian medicine (Ayurveda) through Indian mythology vis-à-vis etiology of the same diseases in the modern western medicine were discussed.

The section Mythology of Japan and Ancient Egypt contained four papers. In The Metamorphosis of "Bateren" and "Kirisitan" Koko Nango (Kobe, Japan) stated that for Japanese myths is not typical to describe how human beings transform into animals or natural effects without death, while in European myths and narratives such motif is widely spread. In his paper Nango aimed to rethink the motif of the metamorphosis of "Bateren" (the Christian missionaries from Europe, who arrived in Japan in the 16th c.) and "Kirisitan" (converted domestic Christians, left in Japan after expelling the missionaries from Japan and executed brutally if they did not abandon their faith), which 
are both constructed by mixing Japanese and European mythic images. But people kept having the images of "Bateren" and "Kirisitan" as magicians who can use supernatural power. There are various depictions of such magic of "Bateren" and "Kirisitan" in the narratives. One "Kirisitan" of the narrative transfigures into fog, another changes himself into an insect. Such motifs of metamorphosis raise a question of their origin, therefore, these narratives must be reconsidered by comparison with European myths.

Hitoshi Yamada (Sendai, Japan) spoke on the topic Crab and Serpent: Tohoku Legends of Flood and Earthquake in Comparative Perspective. As the Japanese Archipelago has repeatedly been struck by natural disasters since time immemorial, and especially after the severe tsunami calamity in 2011, a growing interest in disaster studies can be seen in natural and social sciences as well as in the humanities. H. Yamada compared the legends about natural disasters, collected in the Tohoku region, with parallel tales from Eastern Asia, and argued that some of such traditions may reflect people's real experiences and their wish to hand down emergency instructions to descendants. Of particular interest are legends about the conflict between a crab and a serpent, which causes or stops the flood. This type of narrative is known in Japan, Taiwan, the Philippines, Indonesia, and probably China, so it is widespread in Eastern Asia. Besides, there are legends about specific places which are said to be safe in the case of a flood or an earthquake. These may be based on local inhabitants' experiences and knowledge, which should be re-examined from today's scientific point of view.

David Weiß (Tokyo, Japan) presented Wu Taibo: A Confucian Japanese Founding Myth. This myth is an alternative founding myth, in comparison to the well-known myth of Amaterasu, which enjoyed popularity among Japanese Confucian scholars especially in the early modern period and claimed heavenly descent of the Japanese emperors. In contrast to the Amaterasu myth, Wu Taibo myth traced the sovereigns' genealogy back to a Chinese prince. The Japanese scholars who endorsed this myth were less interested in emphasizing Japanese uniqueness than in showing that the Confucian teachings had been transmitted to Japan at an early date. They argued that Japan was the last stronghold of Confucianism since the Confucian Way had only been maintained in Japan, whereas it was forgotten on the Asian continent. Again, this paper drew attention to the usage of myths for ideological aims. The Wu Taibo myth was given a political interpretation during the 17th century, when Neo-Confucianism came into its own in Japan and brought with it the necessity to find an acceptable position in the sinocentric world order.

David T. Bialock (Los Angeles, USA) presented A Serpentine Story: Reading a Japanese Myth at Earth Magnitude. This paper explored how a period of natural disasters and war gave rise to a new form of geomorphic history centered on Kojiki's (the oldest extant chronicle in Japan, a collection of myths, early legends, songs, etc.) ancient chthonic myth of the serpent (orochi) - the Tale of the Heike (Heike monogatari). Performed by blind biwa reciters attuned to the chthonic energies of serpent and dragon deities, this new geomorphic history was a cultural response to a series of converging natural, climatic, and human disasters in Japan's early medieval period (late 12th to 14th centuries). After following its twists and turns in the Heike, the paper then carried its analysis of this ancient serpentine myth, reworked over the centuries, into the modern period - in the contemporary novel Lake of Heaven (Tenko), written by Ishimure Michiko. 
Keiko Tazawa's (Tokyo, Japan) paper, Water in the Ancient Egyptian Myths, explored the function of water in the Egyptian myths. As in many creation myths in the world, water is an essential element of creation in ancient Egypt. The scholar analyzed not just primordial water, but also many other types of 'water', beginning with tears or libation water through rivers and watery places to 'water of life' in the resurrection ritual for the dead kings in their relations with Re and Osiris. The narratives and mythical fragments were picked up from funerary texts, wisdom literatures, magical texts, hymns, literatures, and offering texts, and connected to each other. The study demonstrated that in ancient Egypt water possessed not simply generative power, but moreover, the power of immortalizing and giving 'the second life' in the afterlife.

According to Attila Mátéffy (Bonn, Germany), Hungarian folklore is quite rich in various eschatological prophecies. In his paper, The Emergence of Other Beings Instead of Humankind at the End of the World: Some Hungarian Eschatological Legends and Fragments Corresponding with the Mongolian Buddhist Concepts, he argued that though the biblical classical form of eschatological prophecies exists in Hungarian folklore, the orally transmitted heritage is still dominant. There are some eschatological legends and fragments, motifs of which can be found neither in the Christian traditions nor in the collections of Sibylline Oracles (Oracula Sibyllina). The latter also influenced the traditional Hungarian eschatological folk beliefs, but surprisingly appear in some Mongolian Buddhist traditions. The scholar listed the most relevant motifs which are: seven years of drought or barrenness as a premonitory sign of the end of the world; the leaves of the walnut-tree will have been shrunken; once the humankind disappears from the Earth, other beings come instead of it; exterminating or sulphurous rain, etc.

Mare Kõiva (Tartu, Estonia) spoke on the topic Mer-People in Baltic-Finnic Tradition. Since Baltic-Finnic ethnic groups live on the territories rich in water bodies and along the shores of the Baltic Sea, their tradition abounds with narratives and beliefs related to mer-people, water spirits, defenders of fish and boats, and kindred beings. Sea fairies and closely related beings, such as sea cows and horses, sea shepherds, fishtailed mermaids and the pharaoh people, ship-bound Klabautermanns, form a separate corpus of texts in their heritage. Folklorists commonly classify stories concerning them as legends, memorates, or personal experience stories, which are characterized by the narrator's belief in the veracity of the encounter, logic-defying meetings with representatives of the supernatural world, and communication with them. The paper examined etiological stories of the pharaoh people, mer-people, sea cattle, and ship spirit Klabautermann (kotermann), about whom it is believed that they represent older mythological beings. These are mostly vernacular beliefs, as the scholar argued, but some have been influenced by newer North-European folklore layers.

Irina Sedakova (Moscow, Russia) in her paper Mythological Creatures of Transition and Beginning analyzed and compared three types of mythological creatures typical of the time of transition and beginning of calendric, lifecycle periods and the start of any activity. She shed light on the archaic seasonal mythological creatures of the opening period of the New Year, e.g., the Twelve Days (Yuletide) (with wide Balkan, Slavic, and Finno-Ugrian mythological parallels) and the Balkan and Slavic Fates who visit the baby and its mother after the childbirth. The third type of creatures are new "global" demons of beginning, the evil spirits of procrastination, which prevent people from working. The pictures of these mythological creatures started to circulate on the Internet, 
depicting definite traditional features of evil spirits (a tail and horns). The study aimed to discover fundamental similarities and differences of the dangerous creatures and to investigate the dynamics of their transformation in time and space up to modernity.

Marina Valentsova (Moscow, Russia) devoted her presentation to the practice of charming hail away in Slavic traditions. She noted that although meteorological magic or weather modification with the help of magic is known to all Slavic peoples, there are substantial differences in various local traditions, including such peculiarities that result from old contacts with the neighboring peoples. For example, Eastern Slavs have mainly occasional and individual enchantment against hail; in the Carpathians and Balkans there were special people-oblakoprogonniki, etc., who possessed magic power to drive away the thunderclouds and concerned themselves with hail suppression in favor of the whole community. Similar beliefs and analogous personages among Romanians, as well as specific elements of the weather enchantment of Hungarians, notable in the Carpathian-Balkan Slavic traditions, allow us to speak about complex processes of repeated borrowings and mutual enrichment within this region with a subsequent formation of a peculiar complex of meteorological enchantment with archaic roots, which "sprout" till nowadays.

Emilia Chalandon (Kobe, Japan) read her own translations into English of the Two Stories from Japanese Mythology Retold, which she intends to publish and thus to make Japanese mythological tales accessible for those who do not read Japanese. These texts are supposed to be published in French and English.

Each paper was followed by a lively discussion, questions, and drawing parallels. The program and the abstracts are available at http://www.compmyth.org/static/IACM_ Sendai_2018_program_FINAL.pdf. In 2019, the 13th conference of the IACM will take place in Estonia.

The topic of the conference dealing with catastrophes was "illustrated" by an excursion to the coastal sites of the Pacific, where in 2011 a natural catastrophe betided: the deadly 20-meters-high swath of the destructive tsunami ruined the costal part of Sendai and washed away more than 20,000 people. There are several memorial locations of religious and secular symbolism there. A museum, ruined houses and remains of the streets are kept so as to commemorate the people who died in this natural disaster.

\section{Irina Sedakova, Marina Valentsova}

\section{ACKNOWLEDGEMENTS}

The authors' participation in the congress and this review were financially supported by the Russian Foundation for Basic Research grant "Linguistic and ethnocultural dynamics of traditional and non-traditional values in the Slavic world" № 18-512-76003, Dr. PhD Irina Sedakova (Program ERA.Net.RUS Call 2018, \# 472-LED-SW). 


\title{
BOOK REVIEW
}

\section{LITERATURE IN AN ESOTERIC KEY}

\author{
Nemanja Radulović (ed.) Esotericism, Literature and \\ Culture in Central and Eastern Europe. Belgrade: Faculty \\ of Philology, University of Belgrade, 2018. 285 pp.
}

The study of Western esoteric traditions and practices, pioneered in the early 20 th century, has been a growing research field since the $1990 \mathrm{~s}$, and over the last twenty years it has become an academic field in its own right. The last two decades have not only challenged the engrained perception that esotericism was not worth of scholarly research, but have also well established its place within academia. The wide range of related ideas, movements, and currents of thought covered by the umbrella-term "Western esotericism" are today explored by scholars from a wide range of disciplines, such as religion, history, ethnography, cultural studies, sociology, philosophy, religious studies, theology, literature, art, Jewish Studies, Islamic Studies, etc. As esotericism has never been too precise, "overflowing its boundaries on all sides" (Faivre 1994: 3), similarly its study does not fit clearly within any particular discipline, making it a trans-disciplinary field par excellence.

Nevertheless, there are already a handful of universities with academic chairs in the subject, as well as several networks dedicated to the advancement of the academic study of this trans-disciplinary field, and to securing its future development, most of which operate under the auspices of the European Society for the Study of Western Esotericism. The year 2014 saw the official constitution of a network meant to embed Western esotericism into the particular space frame of Central and Eastern Europe, namely the Central and Eastern European Network for the Academic Study of Western Esotericism (CEENASWE). The present volume brings before the reader the papers presented at the second conference organized by CEENASWE at the Faculty of Philology at the University of Belgrade in 2016, under the heading Esotericism, literature and culture in Central and Eastern Europe.

What the book does is to propose a different, philological perspective to the study of Western esotericism, as opposed to the dominant ones, deriving from the study of religion. Traditional as it may seem, being partly dedicated to tracking sources and establishing the literary-historical context, in which esotericism came into contact with literature, the approach is a most necessary one, as it fills the gaps in literary historiography and promotes the acknowledgement of esotericism as one of the prominent literary sources in this part of the world, in spite of its belated reception. The twenty papers of this consistent volume coagulate around a rather debated (and debatable) spatial reference point, Central and Eastern Europe, which during time has been known under several names: Slavia Orthodoxa, Slavia Romana, Mitteleuropa, the Byzantine commonwealth, 
the "other Europe", etc. As the time frame was not set, the authors could freely move from the pre-modern forms of Eastern European esotericism up to the modern and contemporary period, proposing the reconsideration of literary sources and histories and revealing considerably broader cultural dynamics, which shows that esotericism has followed certain wider cultural movements.

In spite of the volume not being clearly structured into chapters, around topics or historical periods, which is one of its major drawbacks, the beginning at least seems to follow a chronological order. Hence, the volume opens up with two essays which link the heritage of antiquity to the early modern forms of esotericism in the Eastern Orthodox context. More precisely, the first one looks at esotericism and visionary mysticism in medieval Byzantine heretical literature and backs up the need to integrate the medieval Christian dualism into the comparative scholarly study of Western esotericism (Yuri Stoyanov), while the second one revisits the image of the scientist-magician in the Eastern Orthodox environment, supporting the thesis about the existence of an esoteric discourse in this cultural milieu, despite its being a fragmentary heritage (Vitalii Shchepanskyi).

The second set of papers switches the focus from the Orthodox to the Catholic environment, with alchemy and the figure of the alchemist being the topics around which it gravitates. Jiří Michalík's essay evaluates the very beginnings of the reception of Paracelsus' works in Bohemia and in Czech alchemy, on the basis of Czech alchemists' writings from the 16th century, while György E. Szönyi discusses the Hungarian reception of a novel on alchemy during the Enlightenment, contextualizing the work of the translator in the vivid network of Hungarian and Austrian Rosicrucian and Freemason culture. In his turn, Rafał T. Prinke focuses on the figure of the alchemist, present in many European literary genres, and shows how the popular Polish alchemist Michael Sendivogius has always been presented as an anti-hero.

The Freemasons' contribution to the establishment of journals in Central Europe in the 18th century is the topic of another informative and insightful paper (Martin Javor), while the publishing and cultural activity of Russian esotericists in Yugoslavia in the 1920s-1930s is thoroughly reviewed and analyzed in another (Konstantin Burmistrov). Several other essays consider the influence of occultism and esotericism on the works of particular Central-European authors, which open up new perspectives in the history of literary influences in both Orthodox and Catholic cultures. Thus, for example, Nemanja Radulovic puts forward the provoking idea that the canonic Serbian Romantic poet Petar Petrović Njegoš was inspired both by the Balkan medieval heterodox movement of Bogomilism and by Orthodoxy. Eugene Kuzmin discusses the prominent role of Russian poet Valery Bryusov in spreading occult ideas, as part of his epistemological theory, which may be defined as a special kind of Satanism, while Ruggiero writes about the Czech poet Otokar Březina, caught between symbolism and esotericism. Jan MiklasFrankowski brings to the forefront a neglected collection of essays by Czesław Miłosz as an example of esoteric inspiration, and Sergej Macura examines the underground esoteric currents responsible for the decision of one of Pynchon's fictional characters.

Another consistent section of the book focuses on the Russian, Soviet, and post-Soviet milieu: the esoteric poetry in the late USSR (Stanislav Panin) and the influences of Western esotericism on Russian rock poetry of the turn of the century (Pavel Nosachev). 
Kateryna Zorya puts forth the hypothesis that the most important religious affordance that enables fictional texts to be perceived as religious is neither their fantastical nor their religious elements, but the ability to interface with existing religions, offering the reader an engaging study about a role-playing game in the former Soviet territories fueled by Tolkien spirituality.

A separate, shorter section is dedicated to the influence of esotericism in arts. Spyros Petritakis maps out the networks of Theosophists in pre- and interwar Athens through a series of specific case studies, while Massimo Introvigne shows how the influence of Theosophy is expressed in different artistic currents and trends in the present-day Czech Republic and Slovakia. Nikola Pešić's essay concludes that various New Age ideas from the domain of healing and personal growth have significantly informed the artistic practice of Serbian performance artist Marina Abramović, from the beginning of her career in the 1970s to the present moment.

Last but not least, Ewelina Drzewiecka, in a case study on migrating ideas in the modern Bulgarian tradition, examines the views of the Bulgarian esotericists who represented the two main esoteric schools in this country at the beginning of the 20th century: Dănovism and Theosophy, while Olaf Stachowski explores the possible Hellenistic roots of the popular goetic practice.

The twenty essays of the volume, as diverse as the field itself, testify, from different perspectives, that the reception of esotericism in literature and arts largely overlaps with the shift of influences as formulated by classical literary history. Furthermore, they show that the migration of esoteric ideas through different areas of culture found a most fertile ground in Central and Eastern Europe, proving thus that the editor's concern, expressed in the introduction, that this particular spatial framework might not be appropriate, was not founded.

Finally, following on Stausberg's traces, who stated that the "ingredients" for the development of the new academic field of Western esotericism were basically three - first, the very topic, which resonates with the general interest or the Zeitgeist; second, smart and enterprising scholars and welcoming universities; third, sponsors and publishers who are ready to invest in the nascent field (Stausberg 2013: 219) - one must acknowledge the indisputable merits of Nemanja Radulović, the editor of the volume. Over the past couple of years, thanks exclusively to his commitment and dedication, the study of Western esotericism in Serbia has made significant steps forward, placing Belgrade on the map of important world centers which are able to support the advancement of this prolific field.

Annemarie Sorescu-Marinković Institute for Balkan Studies Serbian Academy of Sciences and Arts 


\section{References}

Faivre, Antoine 1994. Access to Western Esotericism. Albany, NY: SUNY Press.

Stausberg, Michael 2013. What Is It All About? Some Reflections on Wouter Hanegraaff's Esotericism and the Academy. Religion, Vol. 43, No. 2, pp. 219-230. https://doi. org/10.1080/0048721X.2013.767612. 
We are doing our best to use all the versatile possibilities of an online publication. To best ensure a smooth cooperation, please consult the guidelines for authors below; further information on submissions is also available under link "Submission Guidelines" at:

\section{http://www.folklore,ee/folklore/submiss.htm}

Articles can be sent as attachments to e-mails, but if the text contains unconventional special characters, a pdf with embedded fonts is required. The submission must be accompanied by an abstract of 100 250 words) and 5-10 keywords or short phrases in alphabetical order.

Please use endnotes and British or American English spelling. Integrate quotations of less than 40 words in the text using double quotation marks; longer quotations should be separated from the text (without quotation marks) and started on a new line. Provide parenthetical intext citations with author, date and page number in the following format: (Hoppál 1997: 23). All publications cited should be included in the list of references. When compiling the list of references, please follow the example of previous issues of Folklore: Electronic Journal of Folklore. In the list of references, titles of articles or books in other than major languages should be translated into English.

The journal welcomes various types of illustrative materials. Illustrations (photos, figures, music, sound and video samples, etc.) should be submitted as separate files, labelled with a caption, credits, and copyright information. The position of illustrations should be marked in the text. The responsibility for ensuring permissions for the reproduction of illustrative material lies on the author. The acceptable file formats for illustrations are: photos - .jpg or .tif file; line art - .eps or .tif; sound - .mp3, video - .mpg, mp4 or DivX/Xvid avi. 

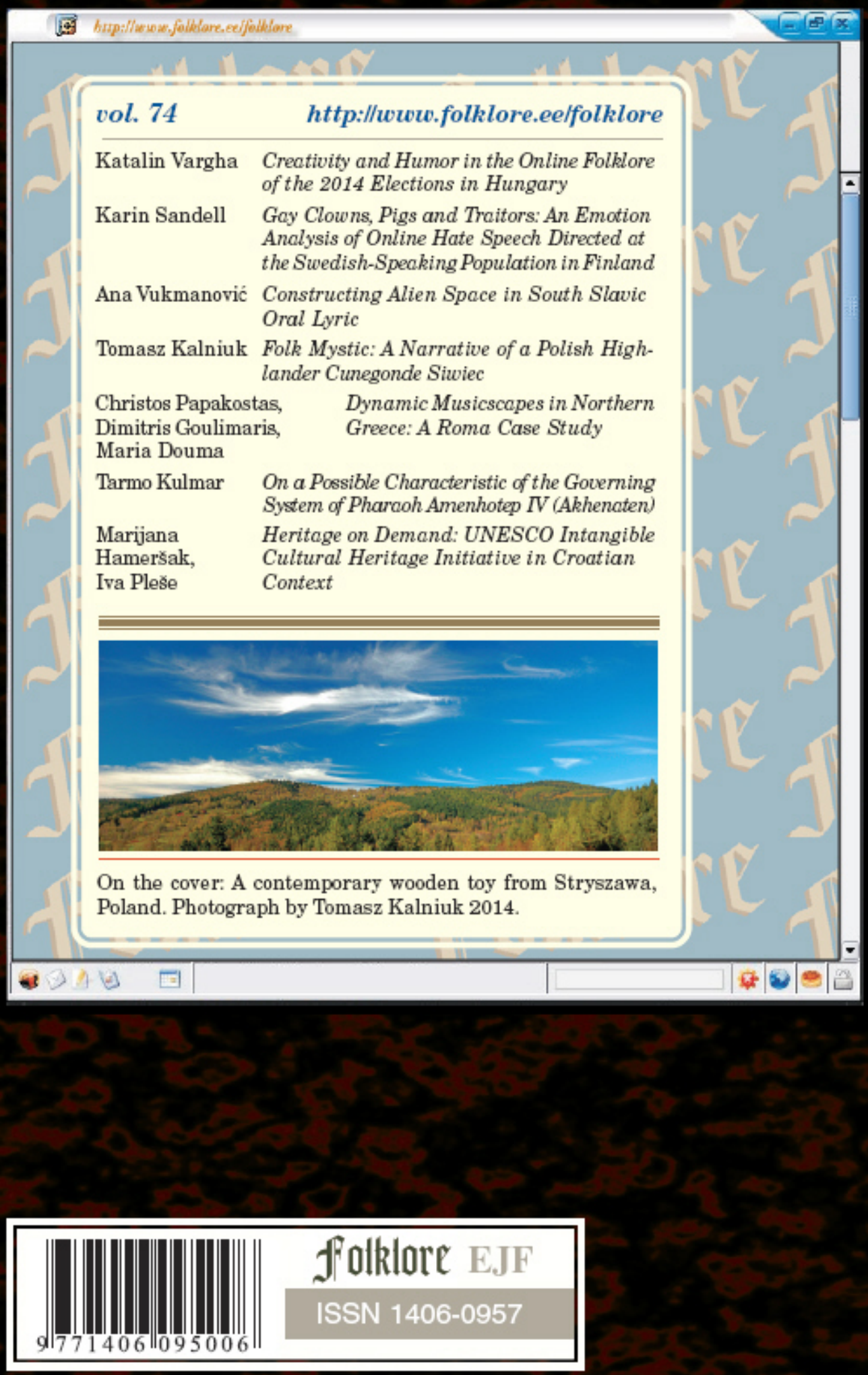